\title{
ipen
}

INSTITUTO DE PESQUISAS ENERGÉTICAS E NUCLEARES

Autarquia Associada à Universidade de São Paulo

\section{PREPARAÇÃO DE HÍBRIDOS METAL/CARBONO POR CARBONIZAÇÃO HIDROTÉRMICA PARA APLICAÇÃO NA OXIDAÇÃO ELETROQUÍMICA DE METANOL}

MARCELO MARQUES TUSI

Tese apresentada como parte dos requisitos para obtenção do Grau de Doutor em Ciências na Área de Tecnologia Nuclear - Materiais.

Orientador:

Dr. Estevam Vitório Spinacé

São Paulo 
INSTITUTO DE PESQUISAS ENERGÉTICAS E NUCLEARES

Autarquia Associada à Universidade de São Paulo

\title{
Preparação de híbridos metal/carbono por carbonização hidrotérmica para aplicação na oxidação eletroquímica de metanol
}

\author{
Marcelo Marques Tusi \\ Tese apresentada como parte \\ dos requisitos para obtenção \\ do Grau de Doutor em Ciências \\ na Área de Tecnologia Nuclear \\ - Materiais.
}

Orientador:

Dr. Estevam Vitório Spinacé

São Paulo 
Dedico este trabalho...

À Michele Brandalise pelos anos de apoio, compreensão e carinho nas horas boas e, principalmente, nas horas difíceis.

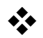

Aos meus pais e meu irmão pelo apoio, amor, carinho e confiança em mim investidos por toda minha vida.

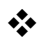

A todos os demais familiares, em especial à Vó Sueli pelo amor, carinho e confiança

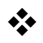

Aos meus orientadores pela confiança, paciência e pelos ensinamentos transmitidos durante esses últimos anos

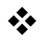

A todos os meus amigos do laboratório e de outras terras longínquas, pois sem o apoio destes a caminhada seria impossivel de ser completada

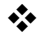

(In Memorian) A Caetano Ferreira Marques,

Josephina Pinto Marques e Olindo Francisco Tusi que, quando em vida, apoiaram-me de todas as formas possíveis. 


\section{AGRADECIMENTOS}

Aos meus pais, Carlos Davi e Zilá e ao meu irmão Cássio pelo apoio incondicional e pelo carinho. À minha avó Sueli pelo apoio. A todos os demais familiares, cujos nomes não cito para não cometer a injustiça de esquecer alguém, que colaboraram nessa caminhada com seu carinho e confiança. In memoriam de Caetano Ferreira Marques (vô Caetano), Josephina Pinto Marques (vó Fina) e Olindo Francisco Tusi (vô Mozo) pelo apoio, carinho e confiança que, quando em vida, nunca foram negados.

À Michele Brandalise (Negra). Talvez nenhuma palavra seja suficiente para agradecer a ajuda e o companheirismo que essa pessoa dedica à mim nos últimos anos. Ela vibra com minhas conquistas e, acima de tudo, é a pessoa em que posso me apoiar quando as coisas não vão bem ou quando fracasso. Ela me ajuda, me dá carinho e agüenta minhas manias.

Aos Dr.s Almir Oliveira Neto e Estevam Vitorio Spinacé pela amizade, conselhos, paciência, conhecimentos transmitidos e orientação.

Ao Dr. Arnaldo H. Paes de Andrade que, em um momento de muita dificuldade, "estendeu a mão" em um ato de confiança e solidariedade.

Ao Dr. Fauze Jacó Anaissi (UNICENTRO-PR) por ter aberto seu laboratório para que eu pudesse realizar medidas imprescindíveis para conclusão deste trabalho.

Aos amigos: José Carlos Penteado (Zeca), Ricardo Dias (Litlle Richard), Fernando Fornarolo, Ary Pereira Júnior, Antônio Carlos da Silva Rodrigues, João A. Pereira. EM ESPECIAL: Roberto Willyan, Ricardo (Bandola), Olandir (Tio), Dionísio (Dio), Luís (Paçoca), Rudy (Gullit), Vilmária, Gabriela Magalhães (Gabi), Jamil Ayoub (Árabe), Antônio Carlos (Inquisitor), Thaís Santoto e Nataly Polanco (Naty). AOS AMIGOS DISTANTES: Everson (Banzé), Juan Villalba, Julio Trevas, Alik, Emerson (Vasca), Joana, Ignácio (Nacho) e Martin.

Aos profissionais: Celso (Cebolinha), Nildemar (Cebolão), Glausson e Eliana Godoy. Essas pessoas além de excelentes profissionais tornaram-se grandes amigos durante minha permanência no IPEN. Ao Vinícius Freire Elias (POLI-METALURGICA) que muito ajudou nas análises de MEV.

Ao IPEN pela infra-estrutura e auxílios financeiros e aos funcionários da CPG pelo auxílio/suporte em assuntos burocráticos relacionados ao doutorado. 


\section{De Boca em Boca}

Andam falando por ai de boca em boca que a nossa fibra e nossa raça esmoreceu que andam pisando em nosso pala e quem consente é, certamente porque a fibra já perdeu.

Nosso cobre na guaiaca anda minguado pela coxilha nuvem negra capereia a pátria grande olha pra além do horizonte $e$ aqui no pago a incerteza nos maneia

A nossa garra vem do tempo das patriadas a nossa fibra é a semente do passado e o destemor é porque nunca aqui no pago por estrangeiro nosso pala foi pisado.

- Meus irmãos abram gaitas e gargantas numa canção que leve fé por onde ande e um canto livre há de elevar-se das coxilhas mostrando a raça deste povo do Rio Grande!

O sangue guapo dos heróis e dos valentes que ainda corre adormecido em nossas veias há de aquecer-se em novas rondas e vigithas nos dando força pra arrebentar as maneias.

Deixe que eles falem por aí de boca em boca pois a nossa fibra e nossa garra não morreu e ninguém pisa em nosso pala e quem consente é, certamente porque a fibra já morreu 


\title{
PREPARAÇÃO DE HÍBRIDOS METAL/CARBONO POR CARBONIZAÇÃO HIDROTÉRMICA PARA APLICAÇÃO NA OXIDAÇÃO DIRETA DE METANOL
}

\author{
Marcelo Marques Tusi
}

RESUMO

Neste trabalho foram preparados híbridos PtRu/Carbono e Ni/Carbono pelo método da carbonização hidrotérmica para aplicação na oxidação eletroquímica do metanol. Nesse processo, uma fonte de carbono e os sais metálicos, em meio aquoso, foram submetidos ao tratamento hidrotérmico a $200 \stackrel{\circ}{\circ} \mathrm{C}$ em uma autoclave. Na preparação dos híbridos PtRu/Carbono foram estudados o uso de diferentes agentes para ajuste do $\mathrm{pH}$ do meio reacional, a influência da adição de surfactante, a razão atômica Pt:Ru, a fonte de carbono, a carga metálica e o tempo de síntese. Para os híbridos Ni/Carbono estudaram-se parâmetros como a fonte de carbono e a adição de brometo de cetiltrimetilamônio. Os materiais obtidos foram caracterizados por espectroscopia de energia dispersiva de raios- $\mathrm{X}$, difração de raios-X (DRX), microscopia eletrônica de transmissão, análise termogravimétrica, isotermas de B.E.T, espectroscopia no infravermelho com transformada de Fourier e voltametria cíclica. Os materiais foram testados para a oxidação eletroquímica do metanol voltametria cíclica, cronoamperometria e em células unitárias operando diretamente com metanol. Os híbridos PtRu/Carbono como-sintetisados não apresentaram atividade na oxidação do metanol. Após tratamento térmico a $900{ }^{\circ} \mathrm{C}$, os materiais tornaram-se ativos e o melhor desempenho foi obtido para o material preparado utilizando celulose, hidróxido de tetrapropilamônio para ajuste do $\mathrm{pH}$ do meio reacional e carga metálica nominal de $5 \%$ em massa. Os resultados indicam que a atividade dos híbridos PtRu/Carbono, provavelmente, está relacionada à estrutura de poros, tamanho de partícula e presença de rutênio segregado. Os híbridos PtRu/Carbono foram tratados termicamente resultando em um material contendo carbono amorfo e grafítico. Os eletrocatalisadores $\mathrm{PtRu} / \mathrm{C}$ preparados utilizando os híbridos $\mathrm{Ni} /$ Carbono como suporte mostraram-se mais ativos que os preparados utilizando o carbono comercial Vulcan XC72, considerado referência na área. 


\title{
PREPARATION OF HIBRIDS METAL/CARBON BY HYDROTHERMAL CARBONIZATION FOR APPLICATION IN THE ELECTRO-OXIDATION OF METHANOL
}

\author{
Marcelo Marques Tusi
}

\begin{abstract}
PtRu/Carbon and Ni/Carbon hybrid materials were prepared by hydrothermal carbonization process for application in the electro-oxidation of methanol. In this process, a carbon source and metal salts in aqueous solution were subjected to hydrothermal treatment at $200^{\circ} \mathrm{C}$ in an autoclave. In the preparation of hybrids PtRu/Carbon it was studied the use of different agents to adjust $\mathrm{pH}$ of the reaction medium, the influence of the addition of surfactant, the atomic ratio $\mathrm{Pt}: \mathrm{Ru}$, the source of carbon, the metallic charge and the synthesis time. For the hybrid $\mathrm{Ni} /$ Carbon it was studied parameters such as the carbon source and addition of cetyltrimethylammonium bromide. The obtained materials were characterized by energy dispersive X-ray, X-ray diffraction, transmission electron microscopy, thermogravimetric analysis, BET isotherms, Fourier transform infrared spectroscopy and cyclic voltammetry. The materials were tested for methanol electro-oxidation by cyclic voltammetry and chronoamperometry and in fuel cell operating directly with methanol. Hybrids PtRu/Carbon as-synthesized showed no activity for methanol electro-oxidation. After thermal treatment at $900^{\circ} \mathrm{C}$, the materials become active and the best performance was obtained for the material prepared using cellulose as a carbon source, tetrapropylammonium hydroxide to adjust the $\mathrm{pH}$ of the reaction medium and nominal metal loading of 5 wt\%. The results showed that the activity of the hybrids PtRu/Carbon appears to be related to pore volume, mesoporous structure, particle size and presence of segregated ruthenium. Hybrids $\mathrm{Ni} /$ Carbon heat-treated at $900^{\circ} \mathrm{C}$ resulted in a material containing amorphous and graphite carbon. The PtRu / C prepared using $\mathrm{Ni} /$ Carbon as support was more active than those prepared using commercial carbon Vulcan XC72, considered as a reference.
\end{abstract}




\section{SUMARIO}

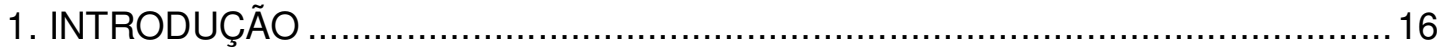

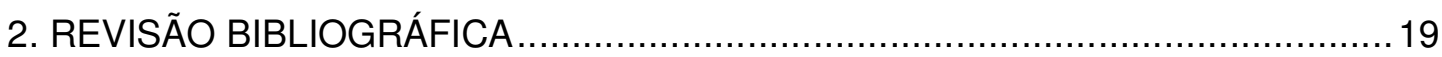

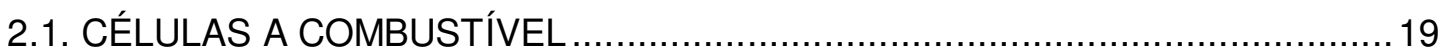

2.1.1. Células a combustível a metanol direto …….................................................22

2.2. O MECANISMO DE OXIDAÇÃO ELETROQUÍMICA DO METANOL ….............24

2.2.1. Mecanismo bifuncional e efeito eletrônico....................................................26

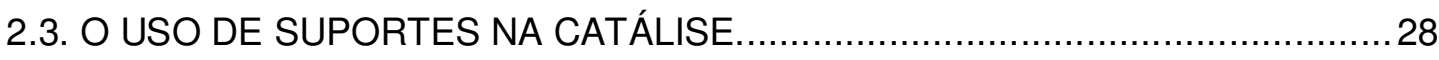

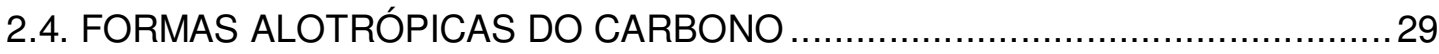

2.5. INFLUÊNCIA DO SUPORTE NA ATIVIDADE DE ELETROCATALISADORES

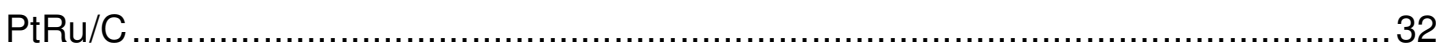

2.6. MÉTODOS DE SÍNTESE DE NANOARQUITETURAS GRAFÍTICAS ................34

2.7. O MÉTODO DA CARBONIZAÇÃO HIDROTÉRMICA ......................................36

2.7.1. Produção de carbono e híbridos metal/carbono por carbonização

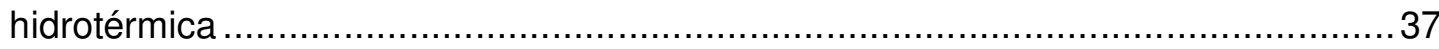

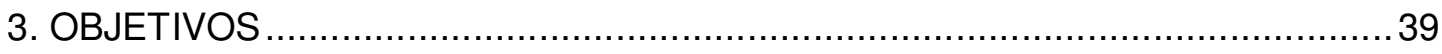

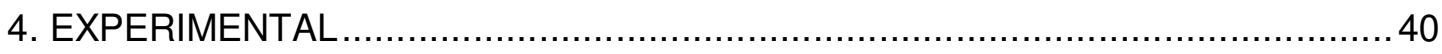

4.1. SÍNTESE DOS HÍBRIDOS PtRU/CARBONO PELO MÉTODO DA

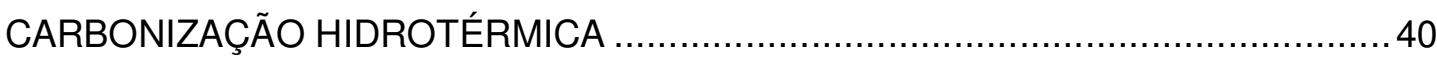

4.2. SÍNTESE DOS HÍBRIDOS Ni/CARBONO PELO MÉTODO DA CARBONIZAÇÃO

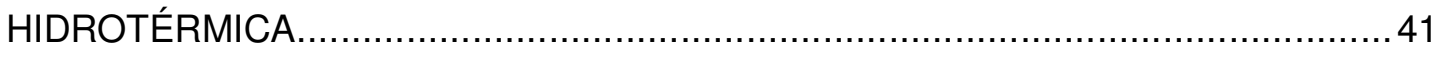

4.3. SÍNTESE DOS ELETROCATALISADORES PtRu/C PELO MÉTOdO DA REDUÇÃO POR ÁLCOOL UTILIZANDO OS HÍBRIDOS Ni/CARBONO PREPARADOS PELO MÉTODO DA CARBONIZAÇÃO HIDROTÉRMICA COMO SUPORTE

4.4. CARACTERIZAÇÃO FÍSICO-QUÍMICA DOS MATERIAIS ..............................42

4.4.1. Microscopia eletrônica de varredura e espectroscopia de energia dispersiva de raios-X 
4.4.2. Espectroscopia no infravermelho com transformada de Fourier. 42

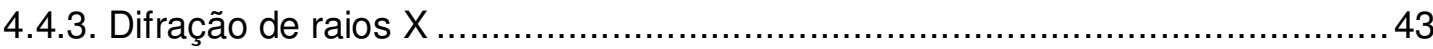

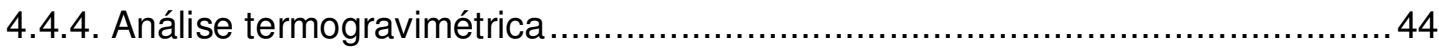

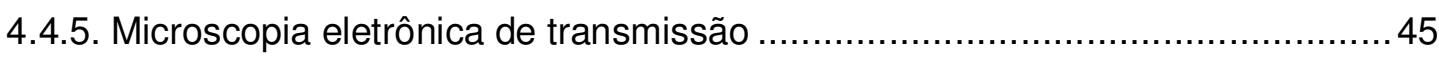

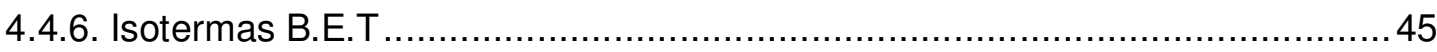

4.5. CARACTERIZAÇÃO ELETROQUÍMICA DOS ELETROCATALISADORES ....... 45

4.6. AVALIAÇÃO DA ELETROATIVIDADE DOS ELETROCATALISADORES ..........46

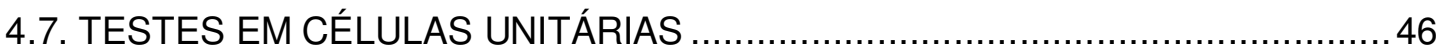

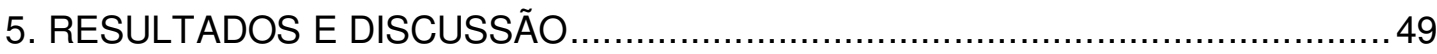

5.1. OXIDAÇÃO DO METANOL SOBRE HÍBRIDOS PtRu/CARBONO PREPARADOS POR CARBONIZAÇÃO HIDROTÉRMICA .................................................... 49

5.1.1. Estudos das condições iniciais de síntese ........................................... 49

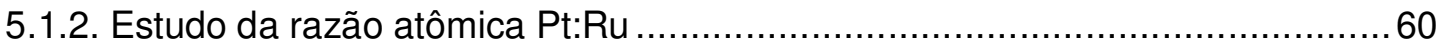

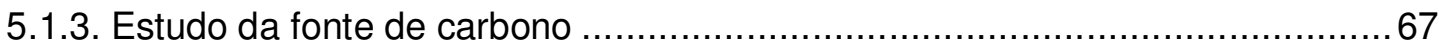

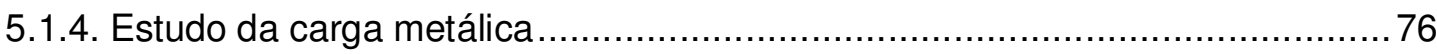

5.1.5. Estudo do tempo de síntese .............................................................. 82

5.2. OXIDAÇÃO DO METANOL SOBRE ELETROCATALISADORES PtRu/C PREPARADOS UTILIZANDO COMO SUPORTE HÍBRIDOS Ni/CARBONO OBTIDOS PELA CARBONIZAÇÃO HIDROTÉRMICA ..................................................... 87

5.2.1. Influência do teor de brometo de cetiltrimetilamônio na preparação do suporte de carbono (Ni/Carbono) por carbonização hidrotérmica .................................... 87

5.2.2. Influência da fonte de carbono na preparação do suporte de carbono (Ni/Carbono) por carbonização hidrotérmica .................................................. 98

5.3. TESTES EM CÉLULAS UNITÁRIAS ALIMENTADAS COM METANOL...........113

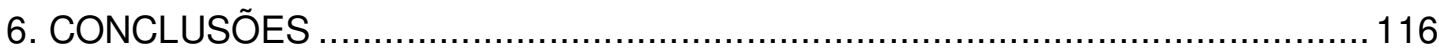

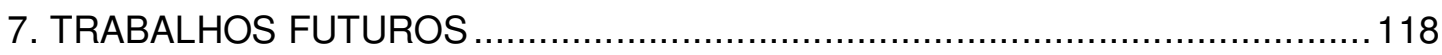

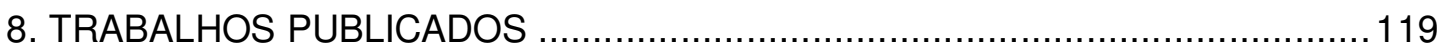

8.1. TRABALHOS PUBLICADOS EM ANAIS DE EVENTOS .............................119 
8.2. TRABALHOS PUBLICADOS EM PERIÓDICOS ................................... 120

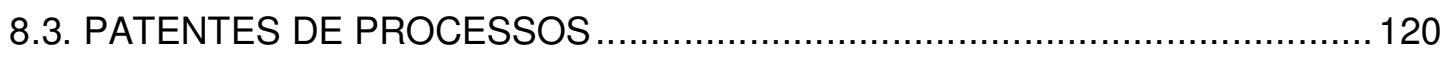

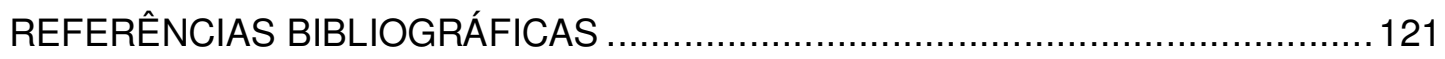




\section{LISTA DE FIGURAS}

FIGURA 1 - Representação de uma célula a combustível de membrana trocadora de prótons [38]. 20

FIGURA 2 - Representação esquemática do mecanismo de oxidação eletroquímica do metanol e seus intermediários. As setas coloridas indicam o mecanismo indireto para formação do $\mathrm{CO}_{2}$ [63]. 24

FIGURA 3 - Estrutura das formas de grafite (a) a (hexagonal) e (b) $\beta$ (romboédrica) $[79,81]$ 30

FIGURA 4 - (a) Diagrama ilustrando como um nanotubo de carbono é formado a partir da folha de grafite; (b) a definição do vetor quiral, para o caso $n=4$ e $m=2$. (c) nanotubos $\operatorname{com} \theta=0^{\circ}(15,0) \theta=30^{\circ}(9,9)$ e $\theta=19^{\circ}(12,6)[82]$.

FIGURA 5 - Autoclave utilizada na obtenção de híbridos metal/carbono por carbonização hidrotérmica. (a) autoclave montada (vista frontal) e (b) autoclave desmontada (vista superior). 40

FIGURA 6 - Espectros de infravermelho dos híbridos PtRu/Carbono preparados por carbonização hidrotérmica e tratados termicamente.

FIGURA 7 - Difração de raios-X das amostras PtRu/Carbono tratadas

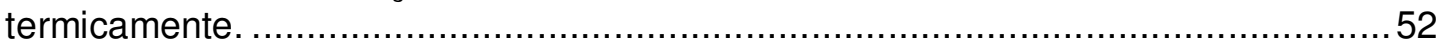

FIGURA 8 - Micrografias obtidas por microscopia eletrônica de varredura dos híbridos PtRu/Carbono, após tratamento térmico, preparados: (a) sem aditivo, (b) com TPACl, (d) com KOH e (e) com TPAOH. 54

FIGURA 9 - Micrografias obtidas por microscopia eletrônica de transmissão e histogramas com a distribuição do tamanho de partículas dos materiais PtRu/C, após tratamento térmico, preparados com (a) TPACl (b) KOH e (c) TPAOH. 56

FIGURA 10 - Voltametria cíclica para os híbridos PtRu/Carbono em solução de 0,5 $\mathrm{mol} \mathrm{L}^{-1}$ de $\mathrm{H}_{2} \mathrm{SO}_{4}$ e velocidade de varredura igual a $10 \mathrm{mV} \mathrm{s}^{-1}$ 58

FIGURA 11 - Cronoamperometrias da oxidação do metanol sobre materiais PtRu/Carbono em solução de $0,5 \mathrm{~mol} \mathrm{~L}^{-1}$ de $\mathrm{H}_{2} \mathrm{SO}_{4}+1,0 \mathrm{~mol} \mathrm{~L}^{-1}$ de metanol em 0,5 $\mathrm{V}$, durante 30 minutos 59

FIGURA 12 - Difratogramas de raios- $X$ dos materiais $P t R u / C$, com diferentes composições, tratadas termicamente. 62

FIGURA 13 - Voltametria cíclica dos materiais PtRu/C com diferentes composições em solução de $0,5 \mathrm{~mol} \mathrm{~L}^{-1}$ de $\mathrm{H}_{2} \mathrm{SO}_{4}$ e velocidade de varredura igual a $10 \mathrm{mV} \mathrm{s}^{-1} \ldots .64$

FIGURA 14 - Voltametria cíclica, para a oxidação do metanol sobre os híbridos PtRu/Carbono com diferentes composições, em solução de $0,5 \mathrm{~mol} \mathrm{~L}^{-1}$ de $\mathrm{H}_{2} \mathrm{SO}_{4}+$ $1,0 \mathrm{~mol} \mathrm{~L}^{-1}$ de metanol e velocidade de varredura igual a $10 \mathrm{mV} \mathrm{s}^{-1}$. 65

FIGURA 15 - Cronoamperometrias para a oxidação do metanol sobre os híbridos $\mathrm{PtRu} /$ Carbono com diferentes razões atômicas, em solução de $0,5 \mathrm{~mol} \mathrm{~L}^{-1}$ de $\mathrm{H}_{2} \mathrm{SO}_{4}$ contendo $1,0 \mathrm{~mol} \mathrm{~L}^{-1}$ de metanol em $0,5 \mathrm{~V}$ durante 30 minutos.

FIGURA 16 - Espectros de infravermelho dos híbridos PtRu/Carbono preparados com diferentes fontes de carbono, após tratamento térmico.

FIGURA 17 - Difratogramas de raios-X dos híbridos PtRu/Carbono, preparados com diferentes fontes de carbono, tratadas termicamente. 
FIGURA 18 - Micrografias obtidas por microscopia eletrônica de varredura dos materiais PtRu/Carbono, tratados termicamente, preparados usando (a) glicose, (b) amido e (c) celulose. 72

FIGURA 19 - Micrografias obtidas por microscopia eletrônica de transmissão dos materiais PtRu/Carbono, tratados termicamente, preparados usando (a) glicose, (b) amido e (c) celulose. 73

FIGURA 20 - Cronoamperometrias da oxidação do metanol sobre híbridos $\mathrm{PtRu} /$ Carbono, preparados com diferentes fontes de carbono, em solução de $0,5 \mathrm{~mol} \mathrm{~L}^{-1}$ de $\mathrm{H}_{2} \mathrm{SO}_{4}$ contendo $1,0 \mathrm{~mol} \mathrm{~L}^{-1}$ de metanol mediante aplicação de $0.5 \mathrm{~V}$ por 30 minutos. 74

FIGURA 21 - Curvas TG dos híbridos PtRu/Carbono preparados por carbonização hidrotérmica com diferentes cargas metálicas, após tratamentos térmicos. 77

FIGURA 22 - Difratogramas de raios-X dos híbridos PtRu/Carbono preparados com diferentes cargas metálicas nominais pela carbonização hidrotérmica e tratados termicamente. 78

FIGURA 23 - Micrografias obtidas por microscopia eletrônica de transmissão dos híbridos PtRu/Carbono, tratados termicamente, com carga metálica nominal de (a) $5 \%$ e (b) $20 \%$. 80

FIGURA 24 - Cronoamperometrias da oxidação do metanol sobre híbridos $\mathrm{PtRu} /$ Carbono, preparados com diferentes cargas metálicas, em solução de $0,5 \mathrm{~mol} \mathrm{~L}^{-1}$ de $\mathrm{H}_{2} \mathrm{SO}_{4}$ contendo $1,0 \mathrm{~mol} \mathrm{~L}^{-1}$ de metanol mediante aplicação de $0.5 \mathrm{~V}$ por 30 minutos. .81

FIGURA 25 - Micrografias obtidas por microscopia eletrônica de varredura dos híbridos $\mathrm{PtRu} /$ Carbono, tratados termicamente, preparados por carbonização hidrotérmica nos tempos de síntese de (a) 6 horas e (b) 12 horas. 83

FIGURA 26 - Difratogramas de raios-X dos híbridos PtRu/Carbono preparados pela carbonização hidrotérmica em diferentes tempos de síntese e tratados termicamente. 84

FIGURA 27 - Cronoamperometrias da oxidação do metanol sobre híbridos $\mathrm{PtRu} /$ Carbono, preparados por carbonização hidrotérmica em diferentes tempos de síntese, em solução de $0,5 \mathrm{~mol} \mathrm{~L}^{-1}$ de $\mathrm{H}_{2} \mathrm{SO}_{4}$ contendo $1,0 \mathrm{~mol} \mathrm{L^{-1 }}$ de metanol mediante aplicação de $0,5 \mathrm{~V}$ por 30 minutos. 86

FIGURA 28 - Difratogramas de raios-X dos híbridos Ni/Carbono (a) comosintetizados e (b) tratados a $900^{\circ} \mathrm{C}$. 89

FIGURA 29 - Imagens obtidas por microscopia eletrônica de transmissão dos híbridos $\mathrm{Ni} /$ Carbono, tratados termicamente, preparados: (a) sem CTAB, e (b) com razão molar glicose: $\mathrm{CTAB}=10$.

FIGURA 30 - Cronoamperometrias da oxidação do metanol sobre eletrocatalisadores $\mathrm{PtRu} / \mathrm{C}$ preparados por co-redução e redução sucessiva dos íons metálicos pelo método da redução por álcool, utilizando como suporte um híbrido Ni/Carbono à base de glicose. Esses experimentos foram realizados em meio de $0,5 \mathrm{~mol} \mathrm{~L}^{-1}$ de $\mathrm{H}_{2} \mathrm{SO}_{4}$ contendo $1,0 \mathrm{~mol} \mathrm{~L}^{-1}$ de metanol, mediante aplicação de $0,5 \mathrm{~V}$ durante 30 minutos. 91

FIGURA 31 - Micrografias obtidas por microscopia eletrônica de transmissão e histogramas com as distribuições dos tamanhos de partícula dos eletrocatalisadores $\mathrm{PtRu} / \mathrm{C}$ preparados utilizando como suporte os híbridos Ni/Carbono preparados (a) sem CTAB e (b) com razão molar glicose:CTAB = 10 
FIGURA 32 - Difratogramas de raios-X dos eletrocatalisadores PtRu/C preparados pelo método da redução por álcool usando híbridos Ni/Carbono com diferentes teores de CTAB como suporte. 94

FIGURA 33 - Voltamogramas cíclicos dos eletrocatalisadores PtRu/C, preparados utilizando híbridos $\mathrm{Ni} /$ Carbono com diferentes teores de CTAB como suporte, em solução $0,5 \mathrm{~mol} \mathrm{~L}^{-1}$ de $\mathrm{H}_{2} \mathrm{SO}_{4} \mathrm{com}$ uma velocidade de varredura igual a $10 \mathrm{mV} \mathrm{s}^{-1} . .95$

FIGURA 34 - Voltametrias cíclicas para a oxidação eletroquímica do metanol sobre os eletrocatalisadores PtRu/C, preparados utilizando híbridos Ni/Carbono com diferentes teores de CTAB como suporte, em solução de $0,5 \mathrm{~mol} \mathrm{~L}^{-1}$ de $\mathrm{H}_{2} \mathrm{SO}_{4}+1,0 \mathrm{~mol} \mathrm{~L}^{-1}$ metanol com velocidade de varredura de $10 \mathrm{mV} \mathrm{s}^{-1}$ 96

FIGURA 35 - Cronoamperometrias da oxidação do metanol sobre os eletrocatalisadores PtRu/C em solução $0,5 \mathrm{~mol} \mathrm{~L}^{-1}$ de $\mathrm{H}_{2} \mathrm{SO}_{4}$ contendo $1,0 \mathrm{~mol} \mathrm{~L}^{-1}$ metanol mediante aplicação de 0,5 V durante 30 minutos. 97

FIGURA 36 - Difratogramas de raios-X dos híbridos Ni/Carbono preparados com diferentes fontes de carbono (a) como-sintetizados e (b) tratados termicamente....100

FIGURA 37 - Imagens obtidas por microscopia eletrônica de transmissão do híbrido $\mathrm{Ni} /$ Carbono preparado usando glicose como fonte de carbono (a) como-sintetizado, (b) tratado a 550ㄷ $\mathrm{C}$ sob argônio, (c) tratado a 900ㄷ sob argônio e (d) dos domínios grafíticos. 101

FIGURA 38 - Imagens de microscopia eletrônica de transmissão, após tratamento a 900 ํ sob argônio, dos híbridos Ni/Carbono preparados pela carbonização hidrotérmica usando (a) glicose e (b) celulose. 102

FIGURA 39 - Espectros de infravermelho dos híbridos Ni/Carbono preparados com diferentes fontes de carbono por carbonização hidrotérmica e tratados a $900{ }^{\circ} \mathrm{C} . .103$

FIGURA 40 - Difratogramas de raios-X dos eletrocatalisadores PtRu/C preparados pelo método da redução por álcool usando como suporte os híbridos Ni/Carbono preparados com diferentes fontes de carbono. 105

FIGURA 41 - Micrografias obtidas por microscopia eletrônica de transmissão e histogramas com a distribuição de tamanho das nanopartículas para os eletrocatalisadores $\mathrm{PtRu} / \mathrm{C}$ usando como suportes híbridos Ni/Carbono preparados (a) com glicose e (b) com celulose. 107

FIGURA 42 - voltamogramas cíclicos dos eletrocatalisadores $\mathrm{PtRu} / \mathrm{C}$, usando como suporte os híbridos $\mathrm{Ni} /$ Carbono preparados com diferentes fontes de carbono, em solução $0,5 \mathrm{~mol} \mathrm{~L}^{-1}$ de $\mathrm{H}_{2} \mathrm{SO}_{4}$, a temperatura ambiente e com uma velocidade de varredura igual a $10 \mathrm{mV} \mathrm{s}^{-1}$ 108

FIGURA 43 - Cronoamperometrias da oxidação do metanol sobre os eletrocatalisadores $\mathrm{PtRu} / \mathrm{C}$, usando como suporte os híbridos $\mathrm{Ni} /$ Carbono preparados com diferentes fontes de carbono, em solução $0,5 \mathrm{~mol} \mathrm{~L}^{-1}$ de $\mathrm{H}_{2} \mathrm{SO}_{4}$ contendo $1,0 \mathrm{~mol} \mathrm{~L}^{-1}$ de metanol, a temperatura ambiente. 109

FIGURA 44 - Difratogramas de raios-X dos eletrocatalisadores $\mathrm{PtRu} / \mathrm{C}$ preparados pelo método da redução por álcool pela co-redução e redução sucessiva dos íons metálicos. 111

FIGURA 45 - Cronoamperometrias da oxidação do metanol sobre os eletrocatalisadores $\mathrm{PtRu} / \mathrm{C}$, preparados por co-redução e redução sucessiva, usando como suporte o híbrido $\mathrm{Ni} /$ Carbono a base de celulose, em $0,5 \mathrm{~mol} \mathrm{~L}^{-1}$ de $\mathrm{H}_{2} \mathrm{SO}_{4}$ contendo $1,0 \mathrm{~mol} \mathrm{~L}^{-1}$ de metanol, mediante aplicação de um potencial de $0,5 \mathrm{~V}$ por 30 minutos, a temperatura ambiente. 
FIGURA 46 - Desempenhos eletroquímicos de uma DMFC $5 \mathrm{~cm}^{2}$ em $100^{\circ} \mathrm{C}$ usando eletrocatalisadores anódicos $\mathrm{PtRu} / \mathrm{C}$ preparados por diferentes métodos (com cargas de $0,5 \mathrm{mg}_{\mathrm{Pt}} \mathrm{cm}^{-2}$ no ànodo e $1,0 \mathrm{mg}_{\mathrm{Pt}} \mathrm{cm}^{-2}$ no cátodo), utilizando membrana Naifion 117 , solução $2 \mathrm{~mol} \mathrm{~L}^{-1}$ metanol com fluxo de $2 \mathrm{~mL} \mathrm{~min}^{-1}$, pressão de oxigênio igual a 2

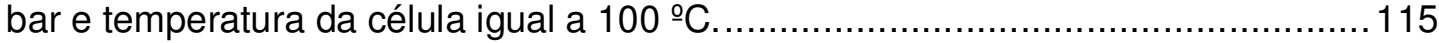




\section{LISTA DE TABELAS}

TABELA 1 - Dados de $\mathrm{pH}$ do meio reacional, razão atômica $\mathrm{Pt}: \mathrm{Ru}$, rendimento de carbonização, perda de massa nos tratamentos térmicos e carga metálica dos híbridos PtRu/Carbono obtidos por carbonização hidrotérmica.

50

TABELA 2 - Tamanho médio de cristalito, o grau de liga, área superficial, volume de mesoporos e volume total de poros dos híbridos PtRu/Carbono. 53

TABELA 3 - Razão atômica Pt:Ru, rendimento de carbonização, perda de massa nos tratamentos térmicos, carga metálica, tamanho médio de cristalito dos híbridos $\mathrm{PtRu} /$ Carbono com diferentes razões atômicas $\mathrm{Pt}: \mathrm{Ru}$. 61

TABELA 4 - Tamanho de médio de cristalito e grau de liga para os híbridos PtRu/Carbono com diferentes composições após tratamento térmico 63

TABELA 5 - Razão atômica Pt:Ru, rendimento de carbonização, perda de massa nos tratamentos térmicos e carga metálica dos híbridos PtRu/Carbono (50:50) preparados com diferentes fontes de carbono.

TABELA 6 - Tamanho médio de cristalito, grau de liga, área superficial, volume de mesoporos e volume total de poros dos híbridos PtRu/Carbono (50:50) preparados com diferentes fontes de carbono.

TABELA 7 - Razões atômicas Pt:Ru, rendimentos de carbonização, perdas de massa após tratamentos térmicos e cargas metálicas dos híbridos PtRu/Carbono (50:50) com diferentes cargas metálicas preparados por carbonização hidrotérmica e tratados termicamente. 76

TABELA 8 - Tamanho de médio de cristalito e grau de liga para os híbridos PtRu/Carbono com diferentes composições após tratamento térmico. 79

TABELA 9 - Razões atômicas Pt:Ru, rendimentos de carbonização, perdas de massa após tratamentos térmicos e cargas metálicas dos híbridos PtRu/Carbono (50:50) preparados em diferentes tempos de síntese por carbonização hidrotérmica.

TABELA 10 - Tamanho médio de cristalito, grau de liga, área superficial, volume de mesoporos e volume total de poros dos híbridos PtRu/Carbono (50:50) preparados em diferentes tempos de síntese, após tratamentos térmicos.

TABELA 11 - Rendimento de carbonização, perda de massa nos tratamentos térmicos, carga metálica e tamanho médio de cristalito de níquel dos híbridos $\mathrm{Ni} /$ Carbono preparados com teores de CTAB. 88

TABELA 12 - Razão atômica Pt:Ru, carga metálica, tamanho médio de cristalito, área superficial e volume total de poros dos eletrocatalisadores $\mathrm{PtRu} / \mathrm{C}$ (50:50), com carga metálica nominal de $20 \%$ em massa, preparados pelo método da redução por álcool usando híbridos Ni/Carbono como suporte. 92

TABELA 13 - Rendimento de carbonização, perda de massa após os tratamentos térmicos, carga metálica e tamanho médio de cristalito dos híbridos Ni/Carbono preparados com diferentes fontes de carbono.

TABELA 14 - Razão atômica Pt:Ru e carga metálica dos eletrocatalisadores PtRu/C (50:50) preparados pelo método da redução por álcool usando como suporte híbridos $\mathrm{Ni} /$ Carbono a base de diferentes fontes de carbono. 104

TABELA 15 - Tamanho médio de cristalito, grau de liga, área superficial, volume de mesoporos e volume total de poros dos eletrocatalisadores PtRu/C usando como 
suporte os híbridos Ni/Carbono preparados por carbonização hidrotérmica com

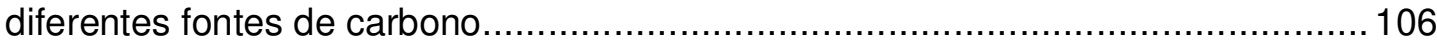

TABELA 16 - Razão atômica Pt:Ru, carga metálica, tamanho médio de cristalito e grau de liga dos eletrocatalisadores $\mathrm{PtRu} / \mathrm{C}$ preparados por co-deposição e por deposição sucessiva pelo método da redução por álcool

TABELA 17 - Método de síntese, fonte de carbono, suporte, tamanho médio de partículas e carga metálica dos materiais testados em células unitárias alimentadas diretamente com metanol. 


\section{INTRODUÇÃO}

O desenvolvimento sócio-econômico e tecnológico mundial apresenta-se fortemente vinculado à demanda por energia, sendo esta uma relação diretamente proporcional [1-4]. Atualmente, o petróleo ocupa um importante papel na matriz energética brasileira e mundial, seguido de outras fontes como o gás natural e o carvão mineral, entre outras [5,6]. Entretanto, todas as fontes energéticas citadas não são renováveis correndo risco de escassez, além dos produtos de suas queimas serem alguns dos responsáveis pela poluição atmosférica [7]. Portanto, governos e órgãos de pesquisa estão empenhados em desenvolver fontes de energia alternativas que sejam eficientes, limpas e renováveis [8].

Nesse contexto, surgem como promissoras fontes de energia as células a combustível [9] definidas como dispositivos eletroquímicos que convertem diretamente a energia química contida nas ligações químicas de um combustível em energia elétrica. Esses dispositivos [10-12] são muito atrativos como fonte de energia para aplicações portáteis, móveis e estacionárias, pois possuem como características a alta confiabilidade e eficiência, baixa geração de ruídos, baixa ou nenhuma emissão de poluentes. Dentre os diversos tipos de células a combustível, a mais promissora para uso em eletrotração e geradores estacionários é a célula com eletrólito polimérico (PEMFC - Proton Exchange Membrane Fuel Cell), pois são robustas e de fácil acionamento e desligamento [11-13].

As células que utilizam uma membrana de intercâmbio de prótons como eletrólito consistem de um ânodo, onde o combustível é oxidado e um cátodo, onde o oxigênio, geralmente do ambiente, é reduzido. A circulação dos elétrons pelo circuito externo produz trabalho elétrico [10].

A obtenção de hidrogênio é feita a partir da reforma a vapor de hidrocarbonetos ou pela eletrólise da água. $O$ hidrogênio obtido pela eletrólise da água possui uma alta pureza, entretanto apresenta um custo relativamente maior do hidrogênio obtido pela reforma gasosa. Por outro lado, o hidrogênio obtido pela reforma gasosa apresenta um teor considerável de impurezas, contendo, aproximadamente, $6 \%$ de monóxido de carbono (CO) $[10,14]$. 
As células a combustível que operam à baixa temperatura não toleram teores de monóxido de carbono superiores a $10 \mathrm{ppm}$, pois esse composto adsorve-se fortemente aos sítios catalíticos de platina, envenenando a platina, ou seja, desativando o eletrocatalisador. Portanto, faz-se necessária a redução do teor de monóxido de carbono no hidrogênio ou o desenvolvimento de eletrocatalisadores mais tolerantes ao mesmo. Esses eletrocatalisadores tolerantes ao monóxido de carbono $[11,15,16]$ têm sido produzidos e consistem de ligas a base de platina com metais como, por exemplo, rutênio [15], estanho [16], dentre outros que facilitam a oxidação do monóxido de carbono a dióxido de carbono. Com o uso destes eletrocatalisadores, teores de monóxido de carbono de até 150 ppm têm sido tolerados [11,17,18].

Entretanto, problemas relacionados ao custo de produção e à infraestrutura de armazenamento e distribuição do hidrogênio dificultam o seu uso como combustível. Por isso, as células que utilizam álcoois diretamente como combustíveis (DAFC - Direct Alcohol Fuel Cells) [19-23], vêm ganhando notoriedade e despertando bastante interesse, pois além de não haver necessidade de produção e armazenamento de hidrogênio, já existe uma infraestrutura para distribuição destes combustíveis. Estas células são muito atrativas como fontes de energia, pois podem ser utilizadas naquelas aplicações citadas anteriormente, além de dispensarem qualquer modificação química ou purificação prévia do combustível [20,22]. O metanol é, mundialmente, o combustível mais estudado na atualidade e, juntamente com o uso do sistema PtRu/C, o que apresenta os melhores resultados [20,23,24].

Estudos mostram que a atividade catalítica dos eletrocatalisadores é fortemente influenciada pelo método de preparação e, consequentemente, pela morfologia dos mesmos [24,25]. Pesquisas também mostram que o uso de carbonos nanoestruturados com diferentes morfologias como, por exemplo, nanotubos, nanofibras e nanomolas de carbono aumentam o desempenho dos eletrocatalisadores PtRu para a oxidação eletroquímica do metanol, entretanto, a síntese destes suportes são, normalmente, complexas e/ou envolvem condições drásticas de temperatura e pressão [26-28]. Recentemente, tem sido proposta a síntese de nanoestruturas metal/carbono em uma única etapa pela carbonização hidrotérmica [29-33]. 
A carbonização hidrotérmica é uma maneira conveniente de converter biomassa (palha, folhas, grama, cavacos de madeira) em nano-estruturas de carbono, sob condições relativamente moderadas. Uma análise estrutural em micro e nano-escala revela que os materiais híbridos metal/carbono obtidos por este método apresentam características interessantes, possibilitando a aplicação destes como suporte e adsorventes. O método apresenta como características a facilidade de execução por não apresentar etapas complexas, além de ser um processo que não agride o meio-ambiente, pois gera apenas o híbrido metal/carbono, água e $\mathrm{CO}_{2}$, sem produção de poluentes $[29,30]$.

A carbonização, também conhecida como pirólise, pode ser definida como uma etapa em que um precursor orgânico é transformado, essencialmente, em carbono. Trata-se de um processo complexo em que muitas reações podem ocorrer ao mesmo tempo tais como desidrogenação, condensação e isomerização [34]. Na síntese de materiais híbridos metal/carbono por carbonização hidrotérmica, o processo global envolve a redução dos metais e conseqüente carbonização do carboidrato utilizado como fonte de carbono [32].

Este trabalho visa a preparação de híbridos PtRu/Carbono pela carbonização hidrotérmica para aplicação como catalisadores da oxidação eletroquímica do metanol, além da síntese de híbridos Ni/Carbono para aplicação como suporte na produção de eletrocatalisadores $\mathrm{PtRu} / \mathrm{C}$ pelo método da redução por álcool também visando a catálise da oxidação do metanol. Foram estudadas algumas variáveis que influenciam na carbonização hidrotérmica e na atividade catalítica dos híbridos como, por exemplo, $\mathrm{pH}$ e influência da adição de surfactante, razão atômica Pt:Ru, fonte de carbono, tempo de síntese e composição da mistura reacional [32,33] a fim de aperfeiçoar o método. Os híbridos PtRu/Carbono e Ni/Carbono e os eletrocatalisadores PtRu/C foram submetidos a uma caracterização físicoquímica e eletroquímica, além de terem seus desempenhos, para a oxidação eletroquímica do metanol, avaliados. Cabe salientar que a produção de híbridos PtRu/Carbono por carbonização hidrotérmica para aplicação na catálise da oxidação eletroquímica do metanol não é relatada na literatura. 


\section{REVISÃO BIBLIOGRÁFICA}

\subsection{CÉLULAS A COMBUSTÍVEL}

Células a combustível $[9,35]$ são dispositivos eletroquímicos que convertem a energia química contida nas ligações químicas de um combustível diretamente em energia elétrica. Tais dispositivos são atrativos como fontes de energia para dispositivos portáteis (celulares, laptops etc), eletrotração de veículos em geral (motocicletas, automóveis, ônibus, entre outros), além de geradores de energia estacionários (para residências, fábricas e sistemas de segurança que necessitem de energia ininterrupta) [10-12,36].

São vários os tipos e configurações de células a combustível em fase de estudo e desenvolvimento, sendo que a classificação destas pode ser realizada de acordo com o tipo de eletrólito utilizado e a temperatura de operação. As células que operam entre a temperatura ambiente e $200^{\circ} \mathrm{C}$ são classificadas como de baixa temperatura de operação e as principais representantes são as Células Alcalinas (AFC - Alcaline Fuel Cells), as Células de Ácido Fosfórico (PAFC - Phosphoric Acid Fuel Cells) e as Células de Membrana Trocadora de Prótons (PEMFC - Proton Exchange Fuel Cells). As células a combustível com temperatura de operação superior a $200{ }^{\circ} \mathrm{C}$ são classificadas como células de alta temperatura de operação e as principais representantes dessa classe são as Células de Carbonato Fundido (MCFC - Molten Carbonate Fuel Cells) e as Células de Óxidos Sólidos (SOFC - Solid Oxide Fuel Cells) [11,14,35].

Características como a alta confiabilidade, alta eficiência, baixa emissão de ruídos e baixa ou nenhuma emissão de poluentes são vantagens das células a combustível quando comparadas a outras fontes de energia [37]. Entretanto, o atual estágio de desenvolvimento desta tecnologia faz com que esses dispositivos apresentem desvantagens como o alto custo de produção e comercialização, problemas de materiais devido às condições de operação e, no caso das células que utilizam hidrogênio, inconvenientes relacionados à produção, distribuição e armazenamento do combustível em questão [11,37].

As células a combustível de membrana trocadora de prótons são robustas e apresentam as maiores densidades de corrente sendo, por isso, consideradas como uma das mais promissoras [11,37]. Estas células são 
constituídas de um ânodo (onde o combustível é oxidado) e um cátodo (onde oxigênio, geralmente do ar, é reduzido). Ânodo e cátodo são compostos por uma tinta contendo o eletrocatalisador Pt/C (nanopartículas de platina suportadas em carbono) misturado com ionômero (Nafion ${ }^{\circledR}$ ), aplicada sobre uma camada difusora constituída de carbono (tecido ou papel) e politetrafluoretileno (PTFE), conforme ilustrado na FIG. $1[10,38]$.

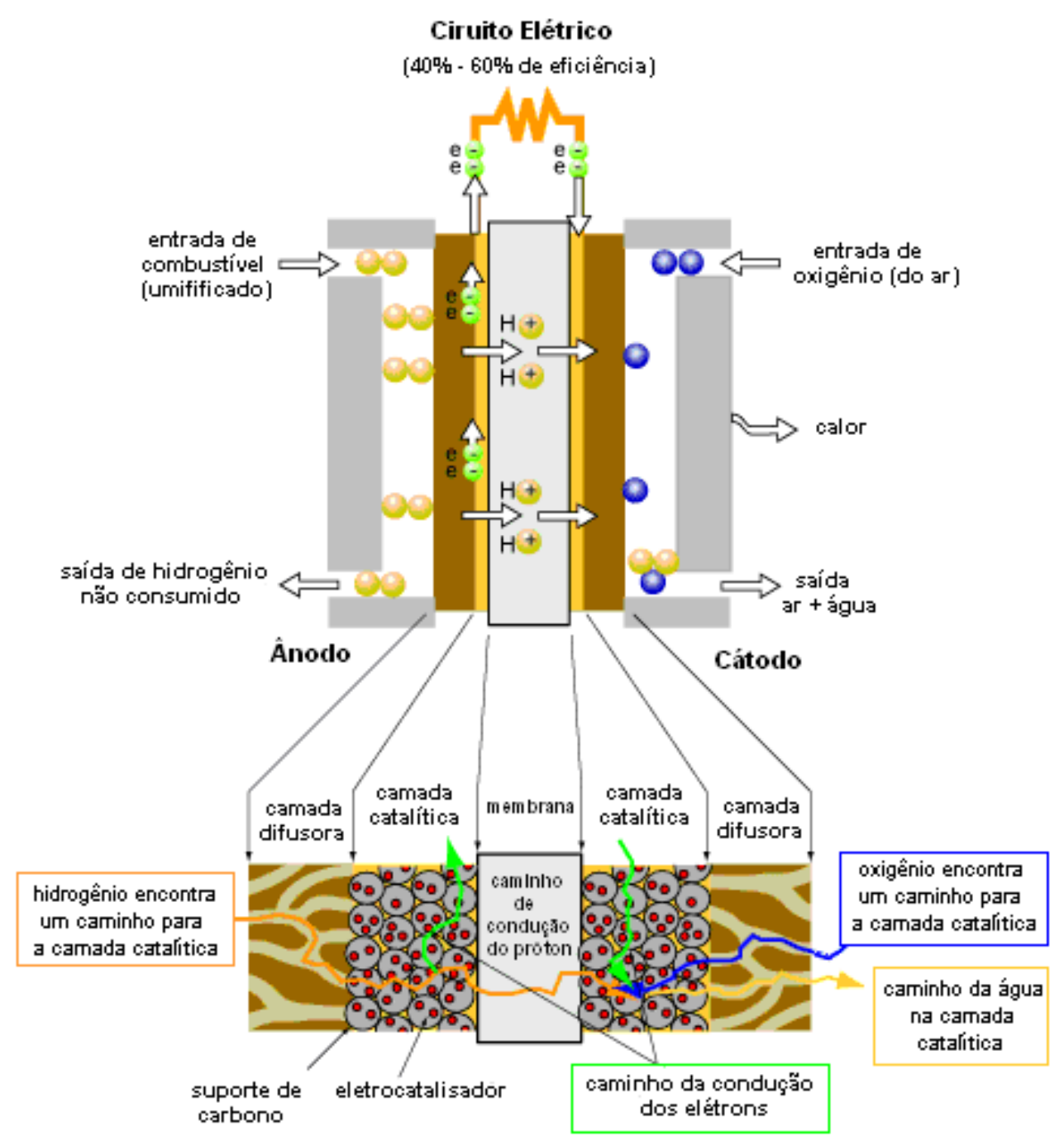

FIGURA 1 - Representação de uma célula a combustível de membrana trocadora de prótons [38].

A oxidação do combustível, no ânodo, gera prótons e elétrons. Os prótons são conduzidos para o cátodo pela membrana trocadora de prótons (geralmente Nafion), enquanto os elétrons são conduzidos para o cátodo pelo circuito externo, produzindo trabalho elétrico. Uma célula a combustível que opera com 
hidrogênio e oxigênio produz apenas água como produto (Equações 1-3), não havendo, portanto, geração de poluentes $[10,11,14]$.

Ânodo: $2 \mathrm{H}_{2}+2 \mathrm{H}_{2} \mathrm{O} \longleftrightarrow 2 \mathrm{H}_{3} \mathrm{O}^{+}+2 \mathrm{e}^{-} \quad$ Equação 1

Cátodo: $2 \mathrm{H}_{3} \mathrm{O}^{+}+2 \mathrm{e}^{-}+1 / 2 \mathrm{O}_{2} \longleftrightarrow 3 \mathrm{H}_{2} \mathrm{O}$ Equação 2

Reação Global: $\mathrm{H}_{2}+1 / 2 \mathrm{O}_{2} \longleftrightarrow \mathrm{H}_{2} \mathrm{O}$ Equação 3

As reações representadas pelas equações acima ocorrem na superfície do catalisador, sendo que ocorre uma transferência de carga entre o reagente e 0 substrato. Dessa forma, o eletrocatalisador deve ser utilizado em uma forma física tal que apresente a maior área superficial possível, ou seja, na forma de nanopartículas. Entretanto, em sistemas eletroquímicos como as células a combustível operando com $\mathrm{H}_{2}$ e $\mathrm{O}_{2}$, um sítio catalítico será efetivo apenas se existir uma tripla fase reacional, onde entram em contato o reagente gasoso, 0 catalisador e o eletrólito [10].

Apesar das vantagens ambientais das células que operam utilizando hidrogênio [10,39], problemas relacionados à produção, distribuição e armazenamento desse combustível, entre outros inviabilizam, no presente momento, a sua utilização [23,36,40,41]. O hidrogênio pode ser produzido por vários métodos como, por exemplo, processos termoquímicos, eletroquímicos, fotoquímicos, fotocatalíticos ou foto-eletroquímicos [39], a partir de biomassa, carvão mineral, combustíveis fósseis ou da água [39,42-44]. Atualmente, a produção de hidrogênio se dá, quase que exclusivamente, de combustíveis fósseis por meio da reforma a vapor do metano ou oxidação parcial de hidrocarbonetos [42]. Entretanto, a produção de hidrogênio por estes métodos resulta na produção de subprodutos como, por exemplo, o monóxido de carbono $[39,42]$ que prejudica o desempenho da célula $[10,11,14]$. Por outro lado, o hidrogênio produzido via eletrólise da água possui uma alta pureza, entretanto a eletrólise da água é o método de obtenção de hidrogênio que apresenta o maior custo [10,42].

Outro problema, já mencionado no texto, está relacionado ao armazenamento do hidrogênio. Trata-se de um problema tão grave que alguns trabalhos $[45,46]$ o classificam como a maior barreira a ser vencida para o desenvolvimento de automóveis movidos a células a combustível. $\mathrm{O}$ 
hidrogênio, em condições normais, ocupa um espaço muito grande $(1 \mathrm{Kg}$ de hidrogênio a temperatura ambiente e pressão atmosférica ocupa um volume de $11 \mathrm{~m}^{3}$ ) e pode ser armazenado como um gás comprimido em cilindros sob alta pressão, como hidrogênio líquido em tanques criogênicos adequados ou no estado sólido como hidretos metálicos ou como materiais capazes de reter quantidades consideráveis de hidrogênio como alanatos, borohidretos, amidas entre outros [46]. Entretanto, as alternativas citadas apresentam problemas como a indisponibilidade comercial dos cilindros com capacidade adequada de armazenamento (seria necessário um cilindro capaz de resistir a uma pressão de $70 \mathrm{MPa}$ com uma massa de $110 \mathrm{~kg}$ para alcançar uma densidade gravimétrica de $6 \%$ e densidade volumétrica de $30 \mathrm{Kg} \mathrm{m}^{-3}$ ) [47], a grande quantidade de energia necessária para liquefazer o hidrogênio, a inevitável perda de combustível por gaseificação do hidrogênio líquido em tanques criogênicos [47] e a baixa capacidade de armazenamento (ou retenção) de hidrogênio dos materiais sólidos [46].

Devido aos inconvenientes relacionados à falta de infra-estrutura para produção, distribuição e transporte do hidrogênio, surge como alternativa promissora o uso de células alimentadas diretamente com combustíveis líquidos, sendo que os álcoois vêm despertando bastante interesse $[19,20,48,49]$.

\subsubsection{Células a combustível a metanol direto}

Nas células a combustível alimentadas diretamente com álcoois (DAFC - Direct Alcohol Fuel Cells), uma solução aquosa de álcool é injetada na célula a combustível, sem qualquer modificação química prévia, sendo o álcool oxidado no ânodo enquanto oxigênio é reduzido no cátodo [22]. O metanol é o álcool mais estudado, sendo considerado o mais promissor, pois é o que apresenta os melhores resultados, devido a sua baixa complexidade molecular. Tais resultados têm sido alcançados por meio do emprego de nanopartículas de platina-rutênio suportadas em carbono (eletrocatalisador $P t R u / C$ ) $[20,23,24]$.

Uma célula a combustível que oxida completamente metanol e reduz oxigênio resulta na formação de dióxido de carbono $\left(\mathrm{CO}_{2}\right)$ e água, envolvendo a transferência de 6 elétrons por molécula de metanol oxidada e um potencial padrão de 1,213 V (Equações 4-6) [50-52]: 
Ânodo: $\mathrm{CH}_{3} \mathrm{OH}+\mathrm{H}_{2} \mathrm{O} \longleftrightarrow \mathrm{CO}_{2}+6 \mathrm{H}_{3} \mathrm{O}^{+}+6 \mathrm{e}^{-} \quad$ Equação 4

Cátodo: $6 \mathrm{H}_{3} \mathrm{O}^{+}+6 \mathrm{e}^{-}+3 / 2 \mathrm{O}_{2} \longleftrightarrow 3 \mathrm{H}_{2} \mathrm{O}$ Equação 5

Reação Global: $\mathrm{CH}_{3} \mathrm{OH}+3 / 2 \mathrm{O}_{2} \longleftrightarrow \mathrm{CO}_{2}+3 \mathrm{H}_{2} \mathrm{O} \quad$ Equação 6

Entretanto, a oxidação completa do metanol dificilmente é alcançada e, como resultado da oxidação parcial desse álcool, muitos subprodutos e intermediários da reação são gerados como, por exemplo, o formaldeído $(\mathrm{HCOH})$, ácido fórmico $(\mathrm{HCOOH})$ e monóxido de carbono (CO) [53].

O metanol apresenta muitas vantagens em comparação ao hidrogênio como a alta solubilidade em eletrólitos aquosos, trata-se de um combustível líquido disponível a um baixo custo, reduz o custo total da célula por não necessitar de um reformador, é facilmente manuseado, transportado e armazenado, além de possuir uma alta densidade energética teórica de, aproximadamente, $6,09 \mathrm{~kW} \mathrm{~h} \mathrm{Kg}^{-1}$, valor comparável ao da gasolina (10 a $\left.11 \mathrm{~kW} \mathrm{~h} \mathrm{Kg}^{-1}\right)[37,49,54]$.

Entretanto, o metanol apresenta desvantagens como sua toxicidade e o seu desempenho limitado devido ao crossover do metanol e a cinética lenta de oxidação do metanol no ânodo $[37,49,54]$. O metanol é considerado um produto tóxico (principalmente neurotóxico), além de possíveis problemas ambientais causados por sua grande miscibilidade em água [49]. O crossover é a permeação do combustível, neste caso o metanol, no sentido do ânodo para o cátodo, podendo ser oxidado no cátodo resultando em uma perda de eficiência do combustível e diminuição da voltagem da célula [55]. A extensão desse fenômeno é influenciada pela concentração do metanol, pressão aplicada no cátodo, temperatura, espessura e massa equivalente da membrana e morfologia do eletrocatalisador [56]. O problema da cinética lenta de oxidação do metanol pode ser superado somente pelo estudo e desenvolvimento de novos catalisadores. Com respeito a novos catalisadores anódicos para células a combustível alimentadas diretamente com metanol (DMFC - Direct Methanol Fuel Cells), há dois desafios maiores referentes ao desempenho (incluindo atividade, confiabilidade e durabilidade) e à redução do custo [23]. 


\subsection{O MECANISMO DE OXIDAÇÃO ELETROQUÍMICA DO METANOL}

Estudos cinéticos [57-59] e mecanísticos [60-63], visando uma melhor compreensão do mecanismo de oxidação eletroquímica do metanol, representam etapas muito importantes no desenvolvimento de catalisadores mais ativos, confiáveis e duráveis para a catálise desta reação [58,63]. A oxidação eletroquímica do metanol é uma reação complexa que envolve muitas etapas paralelas que competem entre si (FIG. 2), além de muitos intermediários possíveis [62,63]. Na FIG. 2, as setas para a direita também incluem a formação de um par próton/elétron (não mostrado), de espécies carbonáceas ou a $\mathrm{H}_{2} \mathrm{O}$ circundante (o último implica a adição de um grupo hidroxila). Setas pontilhadas indicam reações sem geração de um par próton/elétron. Nota-se que reações em fase líquida podem formar $\mathrm{H}_{2} \mathrm{CO}$ e $\mathrm{HCOOH}$, que não estão inclusas nesta análise

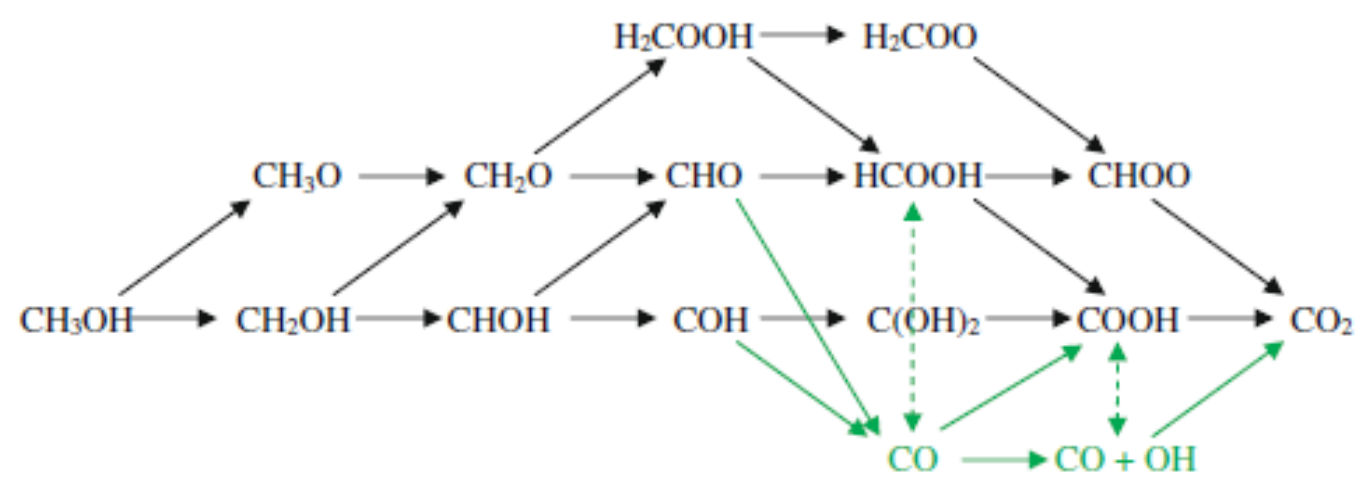

FIGURA 2 - Representação esquemática do mecanismo de oxidação eletroquímica do metanol e seus intermediários. As setas coloridas indicam o mecanismo indireto para formação do $\mathrm{CO}_{2}$ [63] .

Devido ao acúmulo de resíduos orgânicos adsorvidos nos sítios catalíticos, incluindo monóxido de carbono e outras espécies carbonáceas (geralmente, $\mathrm{HCO}$ ou $\mathrm{COH}$ ) provenientes da decomposição parcial do metanol, esta reação apresenta uma cinética lenta, uma vez que tais intermediários bloqueiam os sítios catalíticos, diminuindo as taxas de reação [64].

Segundo Ferrin e colaboradores [63], a primeira etapa no mecanismo de reação, a ativação da molécula de metanol, pode ocorrer via retirada de hidrogênio do átomo do carbono ou oxigênio. Etapas adicionais de abstração de hidrogênio podem gerar formaldeído ou hidroximetileno $(\mathrm{CHOH})$, seguido 
por formil ou $\mathrm{COH}$. No mecanismo direto, em vez de remover o hidrogênio final do $\mathrm{COH}$ ou $\mathrm{CHO}$ para formar $\mathrm{CO}$, um par próton/elétron é removido de uma molécula de água e o grupo $\mathrm{OH}$ resultante combina-se com a espécie carbonácea para formar a espécie dihidroxicarbeno $\left(\mathrm{C}(\mathrm{OH})_{2}\right)$ ou ácido fórmico $(\mathrm{HCOOH})$, conforme apresentado na FIG. 2. Esta adição de hidroxila é seguida por dehidrogenação para formar também formiato ( $\mathrm{HCOO}$ ) ou carboxila $(\mathrm{COOH})$, com subseqüente dehidrogenação para chegar ao produto final. Uma etapa direta alternativa envolve a remoção de um par próton/elétron da água e adição da hidroxila resultante ao formaldeído para formar $\mathrm{H}_{2} \mathrm{COOH}$, que pode ser dehidrogenado à ácido fórmico ou dioximetileno $\left(\mathrm{H}_{2} \mathrm{COO}\right)$. A espécie dioximetileno pode, então, ser dehidrogenado gerando formiato e, finalmente, $\mathrm{CO}_{2}$. No mecanismo indireto, por outro lado, $\mathrm{CHO}$ ou $\mathrm{COH}$ são diretamente dehidrogenados até formar $\mathrm{CO}$. Água é dissociada separadamente na superfície para formar $\mathrm{OH}$ e as duas espécies superficiais reagem juntas para formar $\mathrm{CO}_{2}$ gasoso de maneira análoga à reação de shift água-gás.

As reações de oxidação eletroquímica do metanol sobre platina, algumas mencionadas no parágrafo anterior, estão representadas pelas Equações 7-13 [60,61,65].

$$
\begin{aligned}
& \mathrm{CH}_{3} \mathrm{OH}+\mathrm{Pt}_{(\mathrm{s})} \longrightarrow \mathrm{Pt}-\mathrm{CH}_{2} \mathrm{OH}_{\mathrm{ads}}+\mathrm{H}^{+}+\mathrm{e}^{-} \quad \text { Equação } 7 \\
& \mathrm{Pt}-\mathrm{CH}_{2} \mathrm{OH}_{\mathrm{ads}}+\mathrm{Pt}_{(\mathrm{s})} \longrightarrow \mathrm{Pt}_{2}-\mathrm{CHOH}_{\mathrm{ads}}+\mathrm{H}^{+}+\mathrm{e}^{-} \quad \text { Equação } 8 \\
& \mathrm{Pt}_{2}-\mathrm{CHOH}_{\text {ads }}+\mathrm{Pt}_{(\mathrm{s})} \longrightarrow \mathrm{Pt}_{3}-\mathrm{COH}_{\text {ads }}+\mathrm{H}^{+}+\mathrm{e}^{-} \quad \text { Equação } 9 \\
& \mathrm{Pt}_{3}-\mathrm{COH}_{\text {ads }} \longrightarrow \mathrm{Pt}-\mathrm{CO}_{\text {ads }}+2 \mathrm{Pt}_{(\mathrm{s})}+\mathrm{H}^{+}+\mathrm{e}^{-} \quad \text { Equação } 10 \\
& \mathrm{Pt}_{(\mathrm{s})}+\mathrm{H}_{2} \mathrm{O} \longrightarrow \mathrm{Pt}-\mathrm{OH}_{\mathrm{ads}}+\mathrm{H}^{+}+\mathrm{e}^{-} \quad \text { Equação } 11 \\
& \mathrm{Pt}-\mathrm{CO}_{\text {ads }}+\mathrm{H}_{2} \mathrm{O} \longrightarrow \mathrm{Pt}-\mathrm{COOH}_{\text {ads }}+\mathrm{H}^{+}+\mathrm{e}^{-} \quad \text { Equação 12a } \\
& \mathrm{Pt}-\mathrm{OH}_{\mathrm{ads}}+\mathrm{Pt}-\mathrm{CO}_{\mathrm{ads}} \longrightarrow \mathrm{Pt}-\mathrm{COOH}_{\text {ads }} \quad \text { Equação } 12 \mathrm{~b} \\
& \mathrm{Pt}-\mathrm{COOH}_{\text {ads }} \longrightarrow \mathrm{Pt}_{(\mathrm{s})}+\mathrm{CO}_{2}+\mathrm{H}^{+}+\mathrm{e}^{-} \quad \text { Equação } 13
\end{aligned}
$$

Observa-se que as reações representadas pelas Equações 7-10 são processos de eletrossorção enquanto as demais reações envolvem a transferência de oxigênio para a oxidação dos intermediários ligados à superfície [65].

A extensão de formação de dióxido de carbono bem como dos intermediários citados varia de acordo com a atividade do eletrocatalisador que, por sua vez, é dependente de fatores como a razão atômica entre os metais 
(no caso de eletrocatalisadores plurimetálicos), o tipo de suporte de carbono, o grau de liga, a realização de tratamentos térmicos, o tamanho de partícula, a cristalinidade e morfologia do eletrocatalisador [58].

\subsubsection{Mecanismo bifuncional e efeito eletrônico}

Conforme informações anteriores, o mecanismo de reação de oxidação completa do metanol sobre platina pura pode ser resumido em dois processos que ocorrem em faixas de potenciais diferentes $[60,65]$ :

- PROCESSO 1: envolve a adsorção de moléculas de metanol que requer muitos sítios vizinhos na superfície. Sabendo-se que o metanol não é capaz de deslocar átomos de hidrogênio adsorvidos, a adsorção do mesmo somente pode iniciar em potenciais onde um número suficiente de sítios de platina tornam-se livres de hidrogênios adsorvidos, ou seja, próximo de $0,2 \mathrm{~V}$ versus o eletrodo de referência de hidrogênio $(E R H)$ para um eletrodo de platina policristalina;

- PROCESSO 2: requer a dissociação da água que é a reação de doação de oxigênio. Em um eletrodo de patina pura, uma interação forte da água com a superfície do catalisador é possível apenas em potenciais superiores a 0,4-0,45 V versus $\mathrm{ERH}$.

Portanto, em um catalisador constituído de platina pura, a oxidação do metanol

a $\mathrm{CO}_{2}$ não pode iniciar abaixo de 0,45 V. Entretanto, a camada de adsorbato não exibe uma boa reatividade em potenciais menores que, aproximadamente, $0,7 \mathrm{~V}$, significando que a oxidação de metanol em platina pura ocorre em taxas apreciáveis apenas em valores potenciais que inviabilizam aplicações tecnológicas [60].

No intuito de melhorar o desempenho dos eletrocatalisadores, tornando a reação de oxidação eletroquímica do metanol viável para aplicação em fontes de energia, utilizam-se outros elementos químicos visando facilitar a oxidação do $\mathrm{CO}$ a $\mathrm{CO}_{2}$, sendo que tais elementos denominam-se co-catalisadores [66]. Pode-se citar como elementos pesquisados para a função de co-catalisador o estanho [48], o molibdênio [65], o rutênio [48,58,59,65], terras raras [67] entre muitos outros. Entre estes co-catalisadores, o rutênio é o mais promissor, sendo que o sistema binário composto de nanopartículas de platina e rutênio suportadas em carbono (PtRu/C) tem sido aplicado por muitos anos, sendo 
muito bem investigado e documentado, além de apresentar os melhores resultados para a oxidação do metanol $[23,66]$.

A melhora de atividade observada no sistema PtRu, comparado à platina pura, ou seja, a maior facilidade na remoção do CO tem sido atribuído a dois fenômenos denominados mecanismo bifuncional [15,23,65,66,68,69] e efeito eletrônico (também denominado efeito ligante) [15,70,71] que, embora conhecidos e propostos a alguns anos, ainda não são totalmente compreendidos.

O mecanismo bifuncional, observado na oxidação eletroquímica do metanol sobre um eletrocatalisador $\mathrm{PtRu} / \mathrm{C}$, pode ser representado pelas Equações 14-18 [65].

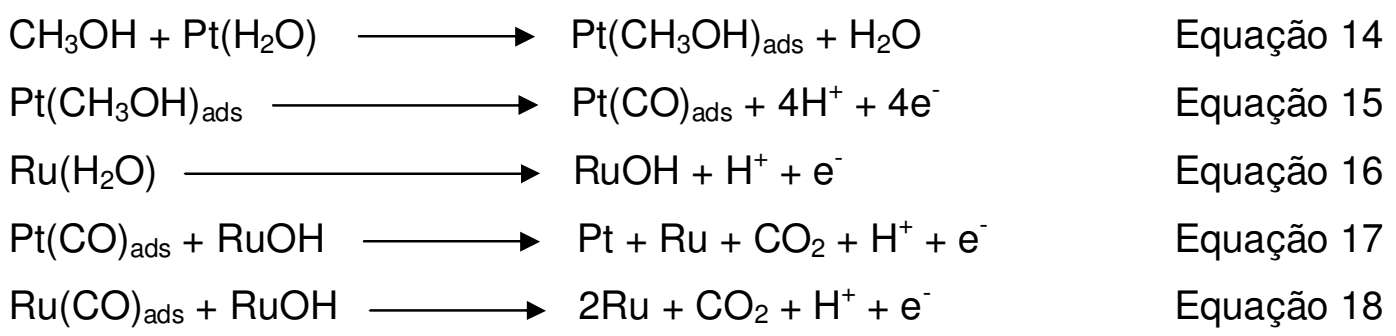

Portanto, o mecanismo bifuncional pode ser definido como o processo pelo qual um elemento, menos nobre que a platina, fornece espécies oxigenadas superficiais (oxi-hidróxidos) a baixos potenciais. Tais espécies atuam como agente oxidante na oxidação do $\mathrm{CO}$ a $\mathrm{CO}_{2}$, resultando na liberação dos sítios catalíticos da platina para uma nova adsorção [15,65,66]. No caso do exemplo representado pelas Equações 14-18, ou seja, o uso do rutênio em associação com a platina, a oxidação do metanol ocorre em um valor de potencial, aproximadamente, $0,2 \mathrm{~V}$ menos positivo que a platina pura [66]. Logo, a denominação "bifuncional" deriva das duas distintas funções desempenhadas pelos metais componentes do eletrocatalisador: enquanto a platina atua na ruptura das ligações $\mathrm{H}-\mathrm{H}, \mathrm{O}-\mathrm{H}$ e $\mathrm{C}-\mathrm{H}$ e $\mathrm{C}-\mathrm{C}$ (função 1), o co-catalisador (geralmente um metal de transição menos nobre que a platina como, por exemplo, rutênio, molibdênio, tungstênio, e níquel) fornece espécies oxigenadas superficiais a baixos potenciais, facilitando a oxidação do CO fortemente adsorvido e, consequentemente, auxiliando na liberação dos sítios catalíticos (função 2) [66]. 
O efeito eletrônico está associado à modificação da estrutura/propriedades eletrônicas da platina pela interação desta com outros elementos constituintes do eletrocatalisador (co-catalisadores), resultando no enfraquecimento da ligação entre o monóxido de carbono e a superfície do eletrocatalisador [15,70,71]. Essa modificação das propriedades eletrônicas da platina dá-se pelo esvaziamento ou maior preenchimento da banda $5 \mathrm{~d}$ da platina seja pela interação com o segundo e/ou terceiro metal do sistema catalítico [72], seja pela dependência da estrutura eletrônica com o grau de liga $[71,73]$ e tamanho de partícula [73]. Novamente, vale salientar que as composições e estruturas cristalinas dos eletrocatalisadores exercem forte influência em parâmetros associados ao mecanismo de atuação e, consequentemente, ao desempenho catalítico desses materiais [71,74,75] como a densidade de estados na superfície do catalisador, a geometria dos adsorbatos e a segregação de fases.

Deve-se ter em mente que não se pode mensurar ou sequer realizar uma previsão da extensão de cada um desses efeitos na atuação do eletrocatalisador durante a oxidação do $\mathrm{CO}$ ou dos demais intermediários adsorvidos nos sítios ativos.

\subsection{O USO DE SUPORTES NA CATÁLISE}

Em passagens anteriores do texto foi mencionado que eletrocatalisadores constituídos de nanopartículas de platina e rutênio suportadas em carbono é o melhor sistema para oxidação eletroquímica do metanol. Catalisadores suportados consistem de uma fase ativa (catalisador) dispersa sobre uma fase carreadora (suporte) [76] e são frequentemente utilizados por combinarem uma dispersão relativamente alta (quantidade de superfície ativa) com um alto grau de estabilidade termodinâmica da fase ativa [77]. Portanto, a função de um suporte é dispersar as nanopartículas impedindo que essas sinterizem, sendo que o componente que realiza a função de suporte deve ser mais resistente à sinterização do que as nanopartículas [76-78].

A seleção de um suporte adequado é baseada em certas características desejáveis para esta função, sendo as principais [76-78]: 
- Propriedades mecânicas desejáveis, incluindo resistência ao atrito, dureza e resistência à compressão;

- Estabilidade sob condições de reação e regeneração;

- Área superficial (alta área superficial é usual, mas nem sempre, desejável);

- Porosidade, incluindo tamanho médio de poro e distribuição do tamanho de poros. Alta área implica em poros minúsculos, mas poros relativamente pequenos (por exemplo, $<5 \mathrm{~nm}$ ) poderiam tornar-se vedados durante o processo de impregnação, especialmente se uma alta carga for demandada;

- Baixo custo.

Apenas três materiais, de uma grande variedade possível, possuem uma boa combinação das características mencionadas: alumina, sílica e carbono ativado, sendo que a alumina é o material mais largamente utilizado na indústria.

No caso dos eletrocatalisadores para células a combustível com membrana trocadora de prótons (PEMFC), o suporte deve apresentar outras propriedades como condutividade eletrônica, resistência à corrosão e propriedades superficiais adequadas [28]. O carbono atende tais necessidades, tornando esse material ideal para suportar nanopartículas metálicas em eletrodos de uma célula a combustível do tipo PEM [28].

\subsection{FORMAS ALOTRÓPICAS DO CARBONO}

De posse da informação de que o carbono é, atualmente, o material mais comumente utilizado como suporte em eletrodos de células a combustível com membrana trocadora de prótons, dar-se-á ênfase a alguns dados sobre esse elemento.

O carbono pode existir em sete estruturas cristalinas: grafite alfa e beta, diamante, lonsdaleíta (diamante hexagonal), caoíta, carbono (VI) e fulerenos $[34,79,80]$. Destas, o a-grafite é termodinamicamente a forma mais estável em pressões e temperaturas normais. As várias modificações diferem também no ambiente de coordenação dos átomos de carbono ou na sequência de empilhamento das camadas no cristal. Estas diferenças possuem forte influência nas propriedades físicas e químicas do elemento [79]. 
O grafite é composto de redes hexagonais planas de átomos de carbono conforme ilustra a FIG. $3[79,81]$.

(a)
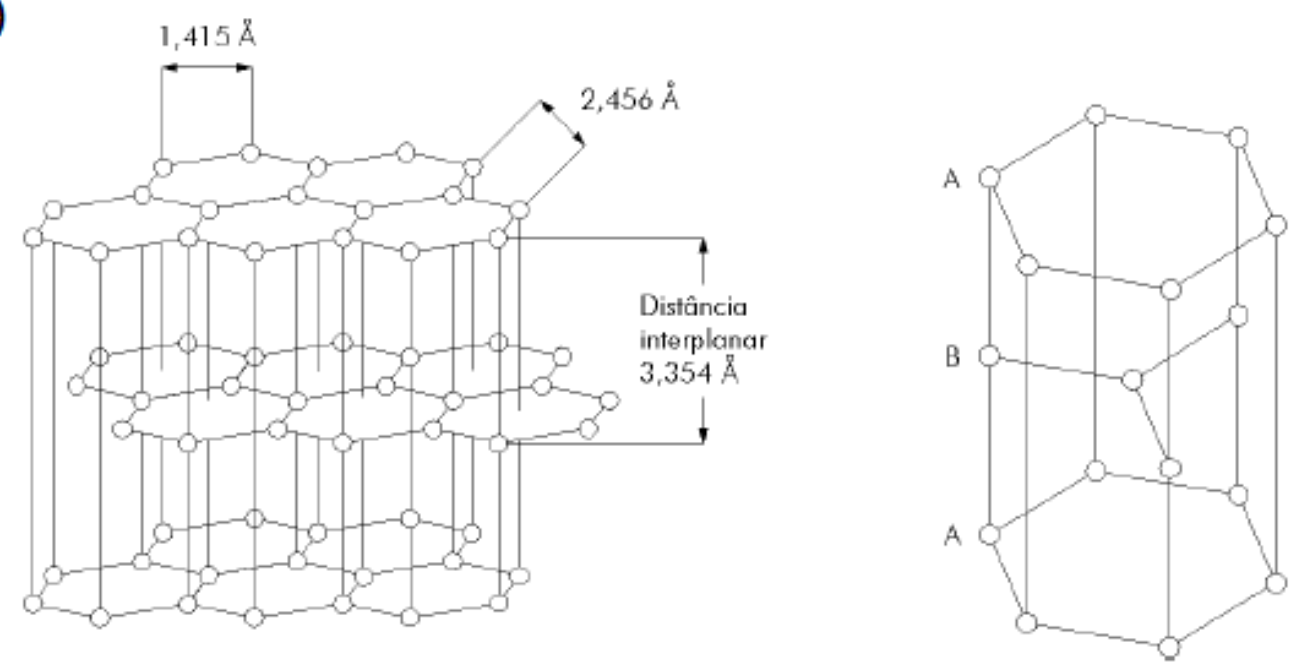

(b)
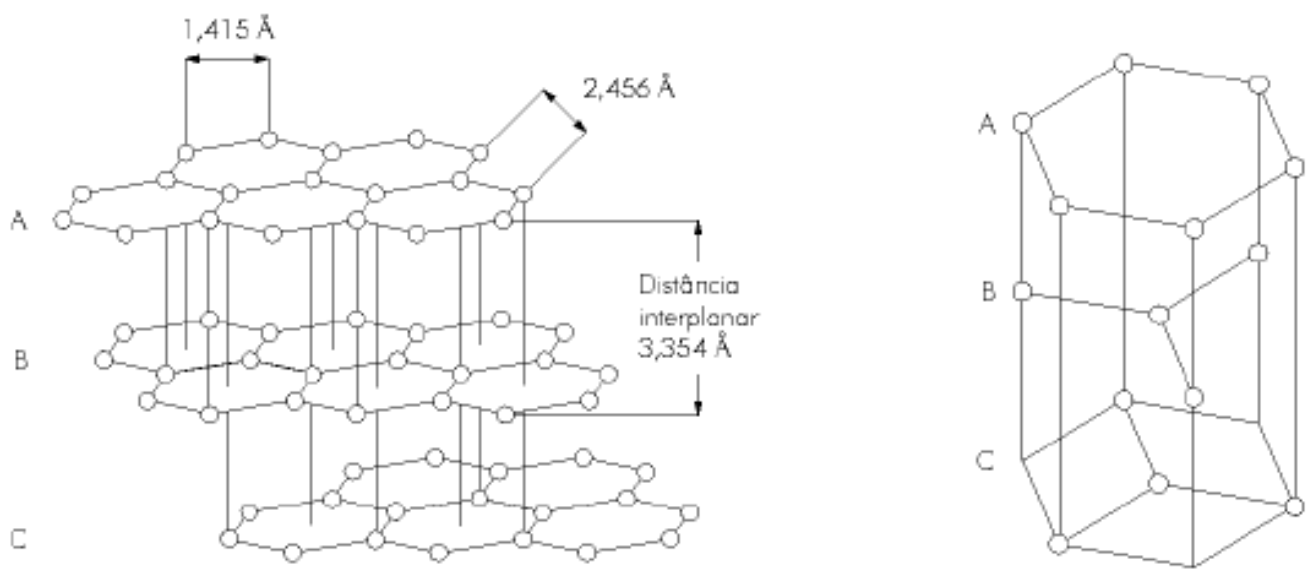

FIGURA 3 - Estrutura das formas de grafite (a) a (hexagonal) e (b) $\beta$ (romboédrica) [79,81].

No a-grafite (ou grafite hexagonal) as camadas são arranjadas na sequência ...ABAB... com átomos de carbono em camadas alternadas verticalmente acima uns dos outros, enquanto no $\beta$-grafite (ou grafite romboédrico) a sequência de empilhamento é ...ABCABC... . Em ambas as formas, a distância C-C dentro da camada é 141,5 pm e o espaçamento interplanar é muito maior, 335,4 pm. O a-grafite pode ser convertido em $\beta$-grafite e vice-versa por moagem $(\alpha \rightarrow \beta)$ ou aquecimento acima de $1025^{\circ} \mathrm{C}(\beta \rightarrow \alpha)$, e conversão parcial 
pode resultar em um aumento no espaçamento médio entre camadas, podendo alcançar um máximo de 344 pm para o grafite turboestrático em que a sequência de empilhamento das camadas paralelas é completamente aleatória. A diferença de entalpia entre o a-grafite e o $\beta$-grafite é apenas $0,59 \pm 0,17 \mathrm{~kJ}$ $\mathrm{mol}^{-1}$ [79]. Pode-se citar como propriedades do grafite [34]:

- Baixa densidade $\left(2,1-2,3 \mathrm{~g} \mathrm{~cm}^{-3}\right.$, dependendo do tipo);

- Oticamente opaco até mesmo em secções extremamente finas;

- Quimicamente estável em temperaturas ordinárias;

- Alta condutividade térmica e elétrica;

- Baixo coeficiente de expansão térmica.

O carbono grafítico pode se apresentar em diferentes morfologias: nanotubos de carbono multicamada [26,82,83], nanomolas [28,84], nanofibras [26,27,34], entre outras.

Os nanotubos de carbono são conceitualmente construídos como sendo formados a partir de uma folha de grafite (grafeno) enrolada em forma cilíndrica, com "um átomo de espessura" (FIG. 4a) [82]. A maneira pela qual a folha de grafeno é enrolada determina a estrutura dos nanotubos e suas propriedades físicas. Os dois parâmetros estruturais relevantes dos nanotubos são: diâmetro $(d t)$ e ângulo quiral $(\theta)$ (também chamado de quiralidade ou helicidade). Usando a estrutura de uma rede hexagonal bidimensional (FIG 4b), pode-se descrever, em primeira aproximação, a estrutura dos nanotubos. Os nanotubos $\operatorname{com} \theta=0^{\circ}$ e $30^{\circ}$ são aquirais e denominados de "zig-zag" $(n, 0)$ e "armchair" $(n, n)$, respectivamente. Os nanotubos com $0^{\circ}<\theta<30^{\circ}$ são denominados de quirais. Na FIG. 4c são mostrados os nanotubos com quiralidades $\theta=0^{\circ}$ [tubo $(15,0)$ ], $\theta=30^{\circ}$ [tubo $(9,9)$ ], e $\theta=19^{\text {o }}$ [tubo $(12,6)][82]$.

Quanto às propriedades eletrônicas, nos nanotubos, os estados eletrônicos permitidos, comparados com o grafeno, são restritos, pois ao longo da circunferência do nanotubo existe uma quantização dos comprimentos de onda associados à função de onda dos elétrons. Somente são permitidos comprimentos de onda com uma relação de número inteiro com o comprimento da circunferência do nanotubo. Como os nanotubos são bastante longos (comprimento micrométrico) os vetores de onda ao longo do eixo são contínuos. Em geral, o caráter metálico ou semicondutor do nanotubo é 
determinado pelos índices $n$ e $\mathrm{m}$. Devido às propriedades de simetria do grafeno tem-se a seguinte classificação: se $n-m$ for múltiplo de 3 , o nanotubo é semicondutor de "gap" quase nulo e, se $n-m$ não for múltiplo de 3 o nanotubo é semicondutor. No caso especial onde $n=m$, o nanotubo é metálico [82].

(a)

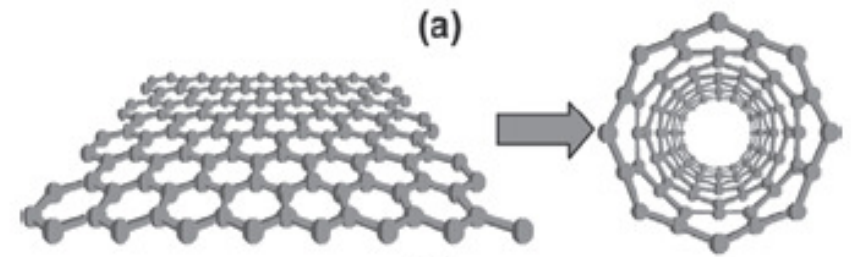

(b)

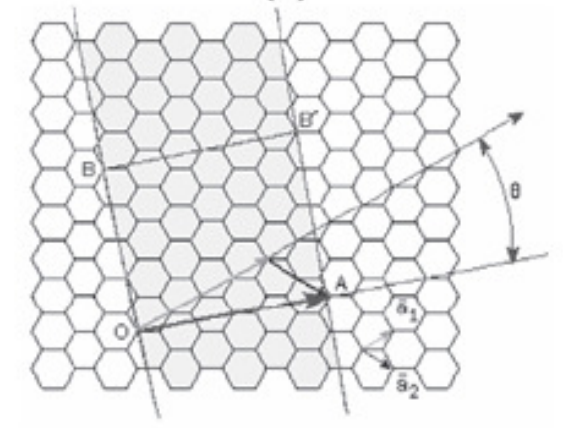

(c)

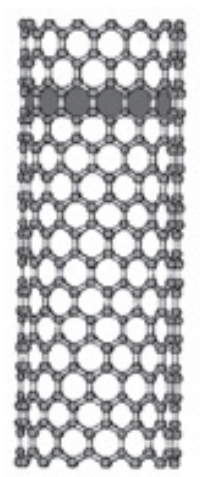

$(15,0)$

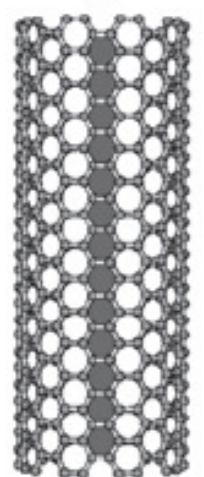

$(9,9)$

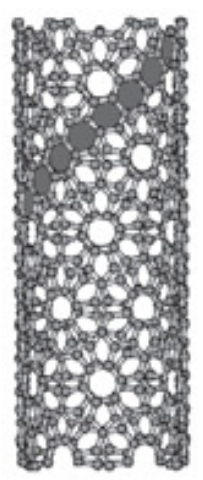

$(12,6)$

FIGURA 4 - (a) Diagrama ilustrando como um nanotubo de carbono é formado a partir da folha de grafite; (b) a definição do vetor quiral, para o caso $\mathrm{n}=4$ e $\mathrm{m}=2$. (c) nanotubos $\operatorname{com} \theta=0^{\circ}(15,0) \theta=30^{\circ}(9,9)$ e $\theta=19^{\circ}$ $(12,6)[82]$.

\subsection{INFLUÊNCIA DO SUPORTE NA ATIVIDADE DE ELETROCATALISADORES PtRu/C}

As propriedades requeridas de materiais de carbono para aplicação como suporte de eletrocatalisadores a base de platina são: alta área superficial 
para alto nível de dispersão das nanopartículas, alta cristalinidade ou baixa resistência elétrica para facilitar o transporte de elétrons durante as reações eletroquímicas, estrutura de poros disponível para maximizar o contato com o combustível e liberação dos produtos e interações benéficas entre as nanopartículas de catalisador e o suporte de carbono. Entretanto, a síntese de materiais de carbono com todas as características citadas, principalmente com alta área superficial e boa cristalinidade, é extremamente difícil [28].

Estudos mostram que a atividade catalítica dos eletrocatalisadores é fortemente influenciada pela morfologia das nanopartículas e do suporte de carbono, tamanho de partícula entre outras propriedades inerentes do método de preparação, ou seja, a eletroatividade está relacionada aos materiais utilizados e ao método de síntese [24,25]. Pesquisas também mostram que o uso de carbonos mesoporosos e nanotubos, nanofibras e nanomolas de carbono aumentam o desempenho dos eletrocatalisadores PtRu para a oxidação eletroquímica do metanol. Entretanto, a síntese destes suportes são, normalmente, complexas e/ou envolvem condições drásticas de temperatura e pressão [26-28]. A seguir serão apresentados alguns estudos que demonstram o uso dessas diferentes nanoarquiteturas de carbono como suportes de eletrocatalisadores PtRu aplicados na oxidação eletroquímica do metanol.

Guo e colaboradores [27] investigaram a oxidação de metanol sobre eletrocatalisadores PtRu suportados em nanofibras de carbono. As fibras de carbono foram sintetizados por deposição química em fase vapor (chemical vapor deposition - CVD) e os eletrocatalisadores PtRu/C preparados pelo método da redução por álcool utilizando etilenoglicol como agente redutor. Os eletrocatalisadores PtRu/C usando as nanofibras de carbono apresentaram os melhores resultados nos testes de células unitárias alimentadas diretamente com metanol.

Park e colaboradores [28] estudaram o desempenho para a oxidação do metanol de eletrocatalisadores PtRu suportados em nanomolas de carbono. As nanomolas de carbono foram preparadas por um processo sol-gel de policondensação de resorcinol e formaldeído seguida de uma carbonização, catalisada por níquel e colbalto, a $900{ }^{\circ} \mathrm{C}$ por 6 horas em atmosfera de nitrogênio. As ancoragens de platina e rutênio nos suportes de carbono foram realizadas pelo método da redução por borohidreto. Foi observado que, nos 
testes eletroquímicos e nos testes em células unitárias, os eletrocatalisadores suportados utilizando as nanomolas de carbono exibiram um desempenho superior para a oxidação do metanol comparado aos materiais usados como suportes disponíveis comercialmente, entre eles o carbono Vulcan XC72.

Park e colaboradores [85] estudaram a oxidação do metanol sobre eletrocatalisadores PtRu, com alta carga metálica, suportados em nanofibras de carbono. As nanofibras de carbono foram produzidas por CVD e os eletrocatalisadores PtRu/C, com carga metálica de $60 \%$, preparados pela redução via borohidreto usando as nanofibras de carbono e carbono Vulcan XC72 como suportes. Também foi preparada uma amostra PtRu sem o uso de suporte, para fins comparativos. Os experimentos eletroquímicos indicaram que os eletrocatalisadores suportados em nanofibras de carbono apresentaram uma melhora de desempenho aproximado de $100 \%$ comparado ao eletrocatalisador suportado em carbono Vulcan XC72.

Prabhuram e colaboradores [86] prepararam nanotubos multicamada (MWCNTs) pela decomposição catalítica de metano $\left(\mathrm{CH}_{4}\right)$ sobre nanopartículas de níquel e, sobre este material, depositaram nanopartículas de PtRu pelo método da redução via borohidreto. Os desempenhos dos eletrocatalisadores suportados em nanotubos de carbono operando como ânodos em células a combustível a metanol direto (DMFC) mostraram-se superiores ao eletrocatalisador PtRu/C comercial da E-TEK.

\subsection{MÉTODOS DE SÍNTESE DE NANOARQUITETURAS GRAFÍTICAS}

Como mencionado, muitos materiais nanoestruturados de carbono com estrutura grafítica, incluindo os nanotubos de carbono, têm sido extensamente estudados. Tais materiais exibem propriedades químicas e físicas interessantes e são aplicados em várias áreas como, por exemplo, emissores de campos elétricos, suportes de catalisadores, nanocompósitos, dispositivos eletrônicos quânticos e materiais para eletrodos diversos. Entretanto, os métodos de síntese desses materiais apresentam limitações em termos de produção comercial devido às condições drásticas de síntese e o baixo rendimento [28]. Os métodos de síntese destes carbonos nanoestruturados são: deposição química em fase vapor (CVD), arco-elétrico e ablação por laser [87-89]. 
No método do arco-elétrico [87-89], nanotubos de carbono são produzidos pela evaporação (por meio de uma descarga elétrica) de duas varetas de carbono com alta pureza distanciadas de $1 \mathrm{~mm}$, sob atmosfera de gás inerte como hélio ou argônio com pressão de 50 a 700 mbar. As varetas de carbono são evaporadas por uma corrente direta de 50 a 150 A controlado por 25 a $40 \mathrm{~V}$ que criarão uma alta temperatura entre os dois eletrodos. Isto faz com que o carbono do ânodo evapore e se deposite na forma de nanotubos no cátodo. O tempo de reação varia de 30-60 segundos até 2-10 minutos. Utilizase como catalisador cobalto e molibdênio [88,89].

No método denominado ablação por laser, método bastante similar ao método do arco-elétrico [87-89], um laser pulsado ou contínuo é usado para vaporizar um alvo de grafite em um forno a $1200{ }^{\circ} \mathrm{C}$. Este forno é preenchido com hélio ou argônio com uma pressão de 500 torr. Trata-se de um método com um custo muito elevado, usado principalmente para a síntese de nanotubos de camada simples (single-wall carbon nanotubes - SWNTs). A vaporização por laser resulta em um maior rendimento de SWNTs com uma distribuição de tamanhos mais estreita que aqueles produzidos pelo método do arco-elétrico. Os diferentes métodos utilizados de ablação por laser são:

- Pulsos Ultra-rápidos de um Laser Livre de Elétrons: são utilizados pulsos com duração de, aproximadamente, $400 \mathrm{fs}$, com uma taxa de repetição do pulso aumentando de $10 \mathrm{~Hz}$ a $75 \mathrm{MHz}$. A intensidade do "pacote" de laser é, aproximadamente, $5.10^{11} \mathrm{~W} \mathrm{~cm}^{-2}$. Um jato de gás argônio pré-aquecido é direcionado sobre o alvo de grafite rotatório. Este jato de gás deflete a ablação de forma perpendicular à direção do feixe incidente, limpando a fuligem de carbono da frente do alvo. Os catalisadores usados são níquel e cobalto ou níquel e ítria [88].

- Onda de Laser Contínua - Método do Pó: este método utiliza um laser de $\mathrm{CO}_{2}$ em vapor de argônio. Ablação por laser da mistura de grafite e pó de catalisador é realizada, devido à perda de condutividade térmica ser significantemente reduzida. O catalisador usado é Ni:Co (1:1). Nanotubos multicamadas (multi-wall carbon nanotubes - MWNTs) também podem ser produzidos utilizando grafite puro [88].

A deposição química em fase vapor (CVD) [87-89] consiste na decomposição catalítica de hidrocarbonetos ou monóxido de carbono com o 
auxílio de catalisadores de metais de transição suportados [89]. A síntese por CVD é realizada em duas etapas [88]:

- ETAPA 1: o catalisador é depositado sobre o substrato e então a nucleação do catalisador é realizado via ataque químico ou tratamento térmico. Amônia é usada como um reagente para ataque químico e níquel, ferro ou cobalto como catalisadores metálicos.

- ETAPA 2: a fonte de carbono, na fase gasosa, é colocada na câmara de reação. Então, o carbono molecular é convertido ao nível atômico pelo uso de uma fonte de energia como plasma ou uma bobina aquecida. Este carbono difundirá para o substrato que é revestido com catalisador e nanotubos crescem sobre este catalisador metálico. As fontes de carbono usadas são metano, monóxido de carbono ou acetileno. A temperatura usada para síntese de nanotubos por CVD está na faixa de 650 a $900{ }^{\circ} \mathrm{C}$ com um rendimento típico de $30 \%$.

É importante salientar que os nanotubos produzidos geralmente contêm uma grande quantidade de impurezas tais como partículas metálicas, carbono amorfo e multicamadas. Há diferentes etapas na purificação dos nanotubos: oxidação ao ar, refluxo em ácido e sonicação auxiliada por surfactante, filtração e tratamento térmico [88].

\subsection{O MÉTODO DA CARBONIZAÇÃO HIDROTÉRMICA}

Como se pode observar no tópico anterior, a síntese de carbonos nanoestruturados envolve condições drásticas de temperatura e pressão, além de exigir, em alguns métodos, reagentes com alta pureza. Entretanto, têm sido proposta e investigada a síntese de nanoestruturas metal/carbono [30-32,90-94] e carbonos mesoporosos ou nanoestruturados [29,95-100] em uma única etapa via carbonização hidrotérmica.

A carbonização hidrotérmica é uma maneira conveniente de converter biomassa (palha, folhas, grama, cavacos de madeira) em nano-estruturas de carbono, sob condições relativamente moderadas. Uma análise estrutural em micro e nano-escala revela que os materiais híbridos metal/carbono obtidos por este método apresentam características interessantes, possibilitando a aplicação destes como suporte e adsorventes. O método apresenta como 
características a facilidade de execução por não apresentar etapas complexas, gerando apenas o híbrido metal/carbono, água e $\mathrm{CO}_{2}$ como produtos [29,30].

A carbonização, também conhecida como pirólise, pode ser definida como uma etapa em que um precursor orgânico é transformado, essencialmente, em carbono. Trata-se de um processo complexo onde muitas reações podem ocorrer simultaneamente, tais como: desidrogenação, condensação e isomerização [34]. Na síntese de materiais híbridos metal/carbono por carbonização hidrotérmica, o processo global envolve a redução dos metais e conseqüente carbonização do carboidrato utilizado como fonte de carbono, conforme a equação apresentada a Equação 19 [32].

$$
\left(\mathrm{C}_{6} \mathrm{H}_{10} \mathrm{O}_{5}\right)_{n}+6 \mathrm{n} \mathrm{M}^{+} \stackrel{\text { tratamento hidrotérmico }}{\longrightarrow} 6 \mathrm{n} \mathrm{C/M}+5 \mathrm{n} \mathrm{H}_{2} \mathrm{O} \quad \text { Equação } 19
$$

Apesar de ser facilmente reproduzido, o método da carbonização hidrotérmica envolve muitas variáveis como a concentração dos reagentes, a natureza dos reagentes (complexidade da fonte de carbono), $\mathrm{o} \mathrm{pH}$ do meio reacional, a temperatura e o tempo de síntese [31]. A seguir serão apresentados alguns trabalhos envolvendo a síntese de carbono ou híbridos metal/carbono pela carbonização hidrotérmica.

\subsubsection{Produção de carbono e híbridos metal/carbono por carbonização hidrotérmica}

Titirici e colaboradores [29] produziram e caracterizaram um carbono mesoporoso por meio da carbonização hidrotérmica de agulhas e cones de pinus e folhas de carvalho em temperatura de $200^{\circ} \mathrm{C}$ por 16 horas.

Kim e colaboradores [33] prepararam carbono esférico grafitizado a partir da carbonização hidrotérmica a uma temperatura de $190 \stackrel{\circ}{\mathrm{C}}$ por 7 horas sob agitação, utilizando sucrose como fonte de carbono e agente redutor e $\mathrm{FeNO}_{3} \cdot 6 \mathrm{H}_{2} \mathrm{O}$ como fonte de metal. $\mathrm{O}$ material obtido foi tratado termica e quimicamente. $O$ carbono resultante foi utilizado como suporte para produção de um eletrocatalisador $\mathrm{PtRu} / \mathrm{C}$, produzido pelo método de redução por borohidreto, sendo o desempenho deste bastante similar ao eletrocatalisador utilizando carbono Vulcan XC-72. 
Sevilla e colaboradores [84] produziram um carbono pela carbonização hidrotérmica de vários sacarídeos (glicose, sucrose e amido). Uma solução aquosa do sacarídeo foi submetida ao tratamento hidrotérmico por períodos de tempo e temperaturas variadas $\left(240{ }^{\circ} \mathrm{C}\right.$ por 30 minutos para a glicose, $190{ }^{\circ} \mathrm{C}$ por 4 horas para sucrose e $200{ }^{\circ} \mathrm{C}$ por 5 horas para amido). Os carbonos provenientes dessa metodologia foram impregnados com íons $\mathrm{Ni}^{2+} \mathrm{e}$ submetidos a uma temperatura de $900{ }^{\circ} \mathrm{C}$ por 3 horas sob nitrogênio, resultando em nanomolas de carbono. Essas nanomolas foram utilizadas como suporte em catalisadores PtRu/C (preparados com nanopartículas PtRu comerciais) que foram testados na oxidação do metanol. Os catalisadores utilizando as nanomolas de carbono como suporte exibiram desempenhos superiores ao catalisador PtRu/C, com carbono Vulcan XC72 como suporte.

Como se pode observar pelos artigos citados neste texto (alguns com seu procedimento citado neste tópico), são escassos os trabalhos envolvendo a produção de híbridos metal/carbono para aplicação como suportes de eletrocatalisadores $\mathrm{PtRu} / \mathrm{C}$. No que diz respeito à produção direta de híbridos PtRu/Carbono por carbonização hidrotérmica, para aplicação como catalisadores da reação de oxidação eletroquímica de metanol, atualmente, com exceção desta tese e dos trabalhos gerados durante a confecção da mesma, atualmente não possuem dados publicados na literatura. 


\section{OBJETIVOS}

O objetivo deste trabalho é desenvolver e aprimorar o método de carbonização hidrotérmica para preparação de híbridos com propriedades tais que tornem esses materiais atrativos para serem utilizados como eletrocatalisadores ou suportes para eletrocatalisadores utilizados na oxidação eletroquímica do metanol. Para tanto, o trabalho dividiu-se em duas partes:

- A primeira parte trata da preparação de híbridos PtRu/Carbono por carbonização hidrotérmica;

- A segunda parte diz respeito à síntese de híbridos Ni/Carbono pela carbonização hidrotérmica que, posteriormente, foram aplicados como suportes de carbono na preparação de eletrocatalisadores $\mathrm{PtRu} / \mathrm{C}$ pelo método da redução por álcool. 


\section{EXPERIMENTAL}

4.1. SÍNTESE DOS HÍBRIDOS PtRU/CARBONO PELO MÉTODO DA CARBONIZAÇÃO HIDROTÉRMICA

Os híbridos PtRu/Carbono foram preparados pelo método da carbonização hidrotérmica [29-33,90-100] utilizando D(+)-glicose (Aldrich), amido (Aldrich) ou celulose (Aldrich) como fonte de carbono e agente redutor, $\mathrm{H}_{2} \mathrm{PtCl}_{6} \cdot 6 \mathrm{H}_{2} \mathrm{O}$ (Aldrich) e $\mathrm{RuCl}_{3} \cdot \mathrm{xH}_{2} \mathrm{O}$ (Aldrich) como fonte de metais e água deionizada como solvente. A mistura é submetida à agitação em um agitador magnético e tem seu pH corrigido para, aproximadamente, 11. Depois de ter o $\mathrm{pH}$ corrigido, a mistura reacional é levada para a autoclave de aço revestida internamente com Teflon com capacidade de 120 mL (FIG. 5) que, por sua vez, é submetida à temperatura de $200{ }^{\circ} \mathrm{C}$ durante um período de tempo que varia de 6 a 48 horas. Ao final do processo, o sólido obtido é filtrado e lavado com água e álcool e, após, seco na estufa a uma temperatura de $70 \stackrel{\circ}{\circ}$ por 2 horas.

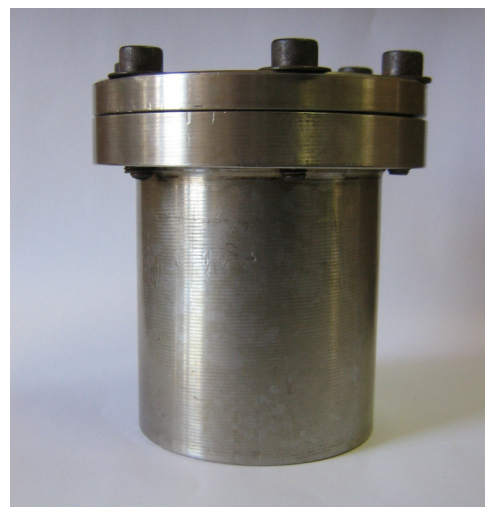

(a)

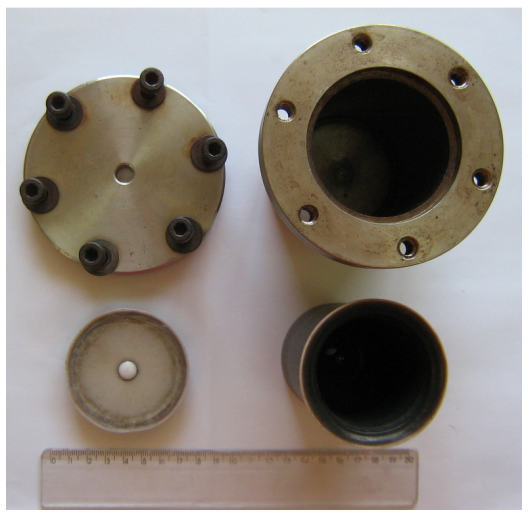

(b)

FIGURA 5 - Autoclave utilizada na obtenção de híbridos metal/carbono por carbonização hidrotérmica. (a) autoclave montada (vista frontal) e (b) autoclave desmontada (vista superior).

O sólido obtido pela carbonização hidrotérmica passa por dois tratamentos térmicos consecutivos. O primeiro tratamento é realizado a $550 \stackrel{\circ}{\mathrm{C}}$ por 4 horas sob argônio com a finalidade de eliminar produtos de carbonização incompleta entre outros compostos que podem prejudicar o desempenho do eletrocatalisador. O segundo tratamento é realizado a $900{ }^{\circ} \mathrm{C}$ por 3 horas sob argônio visando a grafitização do carbono [101]. 
4.2. SÍNTESE DOS HÍBRIDOS Ni/CARBONO PELO MÉTODO DA CARBONIZAÇÃO HIDROTÉRMICA

Os suportes de carbono são obtidos pela carbonização hidrotérmica pelo uso de $\mathrm{D}(+)$-glicose (Aldrich), amido (Aldrich) ou celulose (Aldrich) como fonte de carbono e agente redutor e $\mathrm{NiCl}_{2} .6 \mathrm{H}_{2} \mathrm{O}$ (Aldrich) como catalisador da reação de carbonização e fonte de metal. $\mathrm{O}$ procedimento de obtenção do suporte de carbono é, basicamente, igual ao descrito no item anterior com exceção do tempo de síntese que é modificado para 48 horas e a autoclave utilizada ter uma capacidade de $55 \mathrm{~mL}$. O sólido obtido pela carbonização hidrotérmica é lavado, seco e tratado termicamente como mencionado anteriormente.

O rendimento de carbonização na produção dos híbridos pela carbonização hidrotérmica é calculado através do quociente entre o rendimento experimental e o rendimento teórico (considerando uma massa de partida de 5 g de fonte de carbono). Ou seja, para calcular o rendimento de carbonização, a massa do material como-sintetizado foi dividida pela massa total de átomos de carbono presentes na quantidade de $5 \mathrm{~g}$ da fonte de carbono.

\subsection{SÍNTESE DOS ELETROCATALISADORES PtRu/C PELO MÉTODO DA REDUÇÃO POR ÁLCOOL UTILIZANDO OS HÍBRIDOS Ni/CARBONO PREPARADOS PELO MÉTODO DA CARBONIZAÇÃO HIDROTÉRMICA COMO SUPORTE}

A ancoragem dos metais nos suportes de carbono obtidos pela carbonização hidrotérmica é realizada pelo método da redução por álcool [24,48,67], usando $\mathrm{H}_{2} \mathrm{PtCl}_{6} \cdot 6 \mathrm{H}_{2} \mathrm{O}$ (Aldrich) e $\mathrm{RuCl}_{3} . \mathrm{xH}_{2} \mathrm{O}$ (Aldrich) como fonte de metais, etilenoglicol como solvente e agente redutor, água deionizada como solvente e o suporte obtido pela carbonização hidrotérmica. A solução é submetida a 2 horas de refluxo a $140{ }^{\circ} \mathrm{C}$. O eletrocatalisador obtido é lavado com excesso de água e seco a $70 \stackrel{\circ}{\mathrm{C}}$ por 2 horas. Para fins comparativos, eletrocatalisadores PtRu/C utilizando carbono Vulcan XC72 foram preparados nas mesmas condições aos eletrocatalisadores preparados utilizando os suportes obtidos pela carbonização hidrotérmica. 


\subsection{CARACTERIZAÇÃO FÍSICO-QUÍMICA DOS MATERIAIS}

Os híbridos PtRu/Carbono e Ni/Carbono e os eletrocatalisadores PtRu/C preparados por carbonização hidrotérmica e pelo método da redução por álcool, respectivamente, foram caracterizados por espectroscopia de energia dispersiva de raios-X (EDX), espectroscopia no infravermelho com transformada de Fourier (FTIR), difração de raios-X (DRX), análise termogravimétrica (TGA), microscopia eletrônica de transmissão (MET), e isotermas de B.E.T.

\subsubsection{Microscopia eletrônica de varredura e espectroscopia de energia dispersiva de raios- $X$}

Uma camada fina do eletrocatalisador é colocada em um suporte de alumínio pela prensagem do pó em uma fita dupla face de carbono. As análises foram realizadas no microscópio eletrônico de varredura Philips, modelo XL30 com feixe de elétrons de $20 \mathrm{keV}$ equipado com microanalisador EDAX modelo DX-4.

A partir dos dados obtidos pelas análises de espectroscopia de energia dispersiva de raios- $X$ (EDX) pode-se realizar uma análise semi-quantitativa das amostras.

\subsubsection{Espectroscopia no infravermelho com transformada de Fourier}

Os espectros de infravermelho foram obtidos em um equipamento Thermo Nicolet Nexus 4000 Advanced entre 800 e $3700 \mathrm{~cm}^{-1}$ com 64 varreduras em $4 \mathrm{~cm}^{-1}$ medindo-se no modo transmitância. Na preparação das pastilhas para esses experimentos, $1 \mathrm{mg}$ de material híbrido foi misturado com $500 \mathrm{mg}$ de brometo de potássio $(\mathrm{KBr})$ com posterior prensagem da mistura obtida.

Estas análises permitiram um estudo dos híbridos e eletrocatalisadores, a fim de verificar possíveis grupos funcionais nos mesmos. 


\subsubsection{Difração de raios $X$}

As medidas de difração de raios- $X$ foram obtidas em um difratômetro de raios-X da Rigaku, modelo Miniflex II com fonte de radiação de $\mathrm{CuK}_{\alpha}$ $(\lambda=1,54056 \AA \hat{)})$, em uma velocidade de varredura igual a $2^{\circ}(2 \theta) / \mathrm{min}$.

A análise dos difratogramas de raios- $X$ permitiu a obtenção de informações referentes à estrutura cristalina das partículas contidas no eletrocatalisador bem como a estimativa do tamanho médio das nanopartículas contidas nos eletrocatalisadores, a partir da equação de Scherrer (Equação 20) [102]:

$$
d=\frac{K \lambda}{\beta \cos \theta}
$$

Equação 20

Onde $d$ é o diâmetro médio das partículas em angstrons $(\AA \hat{A}) ; \mathrm{K}$ é a constante que depende da forma dos cristalitos (foi utilizado o valor de $K=0,9$ admitindose cristalitos esféricos); $\lambda$ é o comprimento de onda da radiação usada (no caso a radiação do $\mathrm{CuK}_{\alpha}$, ou seja, $\lambda=1,54056 \AA \hat{\text { ) }}$; $\beta$ é a largura a meia altura do pico (220) em radianos e $\theta$ é o ângulo de Bragg, em grau, para o ponto máximo do pico analisado, ou seja, o pico (220).

Os parâmetros de rede dos eletrocatalisadores foram calculados utilizando os valores do comprimento de onda da radiação usada na aquisição do difratograma $(\lambda)$ e do ângulo de Bragg $(\theta)$, em grau, para o ponto de maior intensidade do pico correspondente à reflexão do plano (220) a partir da Equação 21.

$$
a_{c f c}=\frac{\lambda \sqrt{2}}{\operatorname{sen} \theta} \quad \text { Equação } 21
$$

No cálculo da estimativa do tamanho médio do diâmetro de partículas e do parâmetro de rede utilizou-se o pico correspondente ao plano (220) da estrutura cúbica de face centrada (cfc) da platina, pois no intervalo de $2 \theta$ entre 
$60^{\circ}$ e $75^{\circ}$ pode-se minimizar as contribuições do carbono e de outras eventuais fases de outros elementos de liga [102].

A partir dos valores de parâmetro de rede, calcula-se a fração atômica na liga PtRu. A dependência do parâmetro de rede da liga PtRu não-suportada com o teor de rutênio segue a lei de Vegard [103,104]. Para ligas suportadas, é difícil avaliar o grau de liga, pois a constante de rede de platina pura suportada é menor que de platina não-suportada (devido às interações platina-carbono) e a fração atômica de rutênio na liga cfc é menor que o teor de rutênio nominal na amostra. Assumindo que a dependência do parâmetro de rede com o teor de rutênio é o mesmo para platina suportada e não-suportada, a constante de rede da liga PtRu suportada (aptRu/c) é dada pela Equação 22:

$$
a_{P t R u C}=a_{P t}-k x_{R u}
$$

Equação 22

onde $a_{P t}=3,9155$ Á é o parâmetro de rede platina pura suportada em carbono, $k=0,124 \AA$ é uma constante da relação para ligas não-suportadas e $x_{R u}$ é a fração de rutênio na liga [103,104]. Usando o valor de $x_{R u}$ calculado pela Equação 22, calcula-se a quantidade de rutênio na liga $\left(R u_{\text {liga }}\right)$, também denominado grau de liga, pela Equação 23:

$$
R u_{\text {liga }}=\frac{x_{R u}}{\left[\left(1-x_{R u}\right)(R u / P t)_{n o \min a l}\right]}
$$

onde $(R u / P t)_{\text {nominal }}$ é a razão atômica Pt:Ru obtida por EDX.

\subsubsection{Análise termogravimétrica}

As análises termogravimétricas [105,106] foram realizadas em um instrumento Shimadzu D-50. A amostra é colocada em um cadinho de platina sendo submetida a um aquecimento da temperatura ambiente até $700^{\circ} \mathrm{C}$, a uma taxa de $5^{\circ} \mathrm{C} / \mathrm{min}$ sob atmosfera de oxigênio seco com fluxo de $30 \mathrm{~mL} / \mathrm{min}$.

A determinação da porcentagem de níquel nos híbridos Ni/Carbono foi realizada nas mesmas condições citadas no parágrafo anterior, porém 
utilizando um equipamento de análise simultânea TGA/DTA Seiko (modelo 6300).

Os experimentos de termogravimetria permitem a determinação da carga metálica, em porcentagem em massa, presente no catalisador. $O$ valor da carga metálica é importante para a normalização (por grama de platina) dos resultados eletroquímicos [48].

\subsubsection{Microscopia eletrônica de transmissão}

Os dados de microscopia eletrônica de transmissão foram obtidos em um equipamento JEOL-JEM2100 operando em 200 kV.

Através das micrografias obtidas por microscopia eletrônica de transmissão é possível avaliar a dispersão (homogeneidade) e o tamanho das nanopartículas bem como construir histogramas mostrando a distribuição de tamanhos das nanopartículas.

\subsubsection{Isotermas B.E.T}

As isotermas BET foram determinadas em um equipamento Micromeritics GEMINI V 2380. As amostras são tratadas em uma temperatura de $150 \stackrel{\circ}{\circ}$ por 1 hora a fim de remover gases previamente adsorvidos. Área superficial específica e volumes de microporos e mesoporos foram determinados por meio da adsorção de $\mathrm{N}_{2}$ em -196 ${ }^{\circ} \mathrm{C}$ usando BET multiponto, método t e análises $\mathrm{BJH}$, respectivamente.

Através das isotermas BET faz-se possível a determinação da área superficial e estrutura de poros (volume de microporos e mesoporos) dos eletrocatalisadores. Esses dados são importantes, pois estão entre as propriedades que influenciam na atividade dos eletrocatalisadores $[26,28]$.

\subsection{CARACTERIZAÇÃO ELETROQUÍMICA DOS ELETROCATALISADORES}

Os eletrocatalisadores obtidos foram eletroquimicamente caracterizados através da técnica de voltametria cíclica [107] e da técnica da camada fina porosa $[10,22,48]$.

A técnica da camada fina porosa consiste na preparação de uma pasta através da mistura de $20 \mathrm{mg}$ do eletrocatalisador, $50 \mathrm{~mL}$ de água deionizada e 3 gotas de uma dispersão $6 \%(\mathrm{v} / \mathrm{v})$ de Teflon. A mistura é submetida a um 
sistema de ultra-som por 10 minutos. Posteriormente, a mistura é filtrada e o sólido ainda úmido é transferido para a cavidade $(0,3 \mathrm{~mm}$ de profundidade e $0,36 \mathrm{~cm}^{2}$ de área) do eletrodo de trabalho, sendo então compactado de forma que a superfície fique homogênea.

Os experimentos de voltametria cíclica foram realizados usando uma célula de três eletrodos [108]: o eletrocatalisador como eletrodo de trabalho, um eletrodo reversível de hidrogênio $(\mathrm{ERH})$ como eletrodo de referência e uma placa de platina como contra-eletrodo. Esses experimentos foram executados em um potenciostato/galvanostato Microquímica (modelo MQPG 01, Brasil) acoplado a um computador usando o software Microquímica para interface. Foi utilizada, como eletrólito suporte, solução $0,5 \mathrm{~mol} / \mathrm{L}$ de $\mathrm{H}_{2} \mathrm{SO}_{4}$. Os estudos foram feitos no intervalo de potencial de $0,05 \mathrm{~V}$ a $0,8 \mathrm{~V}$ com uma velocidade de varredura igual a $10 \mathrm{mV} / \mathrm{s}$. Os experimentos foram executados primeiro na ausência de álcool e posteriormente na concentração de 1,0 mol/L de metanol em solução saturada com $\mathrm{N}_{2}$ a temperatura ambiente.

\subsection{AVALIAÇÃO DA ELETROATIVIDADE DOS ELETROCATALISADORES}

A atividade catalítica dos eletrocatalisadores foi avaliada através de experimentos de voltametria cíclica e cronoamperometria, tendo como base a mesma montagem experimental dos experimentos de voltametria cíclica utilizados para a caracterização dos materiais.

Os experimentos para avaliação da eletroatividade dos eletrocatalisadores foram realizados a temperatura ambiente em uma solução de $0,5 \mathrm{~mol} \mathrm{~L}^{-1}$ de $\mathrm{H}_{2} \mathrm{SO}_{4}$ contendo $1,0 \mathrm{~mol} \mathrm{~L}^{-1}$ de metanol ou etanol, saturada com $\mathrm{N}_{2}$. Esses estudos foram executados mediante a aplicação, no eletrocatalisador (eletrodo de trabalho), de um potencial de $500 \mathrm{mV}$ durante 30 minutos.

\subsection{TESTES EM CÉLULAS UNITÁRIAS}

Para os estudos em célula a combustível unitárias alimentadas diretamente por metanol foi utilizada a membrana Nafion® 117 (DuPontTM) como eletrólito. Antes de cada experimento realizado as membranas eram cortadas nas dimensões de $10 \mathrm{~cm} \times 10 \mathrm{~cm}$ e pré-tratadas quimicamente com $\mathrm{H}_{2} \mathrm{O}_{2}(3 \%)$ e com $\mathrm{H}_{2} \mathrm{SO}_{4}\left(1,0 \mathrm{~mol} \mathrm{~L}^{-1}\right)$ a $80{ }^{\circ} \mathrm{C}$ para remover eventuais 
impurezas orgânicas e minerais. Entre um tratamento e outro as membranas eram imersas em $\mathrm{H}_{2} \mathrm{O}$ destilada a $80{ }^{\circ} \mathrm{C}$. A duração de cada etapa de tratamento foi de uma hora. Após os tratamentos químicos na presença de $\mathrm{H}_{2} \mathrm{O}_{2}$ e $\mathrm{H}_{2} \mathrm{SO}_{4}$ foram realizados os tratamentos na presença de água destilada e o procedimento foi repetido por mais três vezes.

A camada difusora (GDL do inglês Gas Diffusion Layer) empregada na confecção de todos os MEAs foi o tecido de carbono (EC-CC1-060T), o qual é tratado com PTFE (35\%) fornecido pela ElectroChem Inc.

A camada catalítica do catodo foi preparada utilizando o catalisador comercial Pt/C E-TEK (20\% de Pt em massa, lote: C0740621) com $1 \mathrm{mg}_{\mathrm{Pt}} \mathrm{cm}^{-2}$ e $30 \%$ de $\mathrm{Nafion} \circledast$, já para a preparação da camada catalítica do ânodo foi utilizado $0,5 \mathrm{mg}_{\mathrm{Pt}} \mathrm{cm}^{-2}$ dos eletrocatalisadores PtRu/C comercial da E-TEK e preparados por carbonização hidrotérmica e método da redução por álcool 30\% de Nafion® (dispersão 5\% DE520 da DuPontTM).

As camadas catalíticas preparadas foram aplicadas manualmente sobre o tecido de carbono pela técnica de pintura por pincel até a total transferência da carga catalítica. Após a pintura dos eletrodos estes foram colocados na estufa a $70{ }^{\circ} \mathrm{C}$ por 2 horas para secagem. Em seguida para a formação do MEA os dois eletrodos preparados foram prensados junto à membrana de Nafion, a $125^{\circ} \mathrm{C}$ por 3 minutos a uma pressão de 7 toneladas.

A avaliação do desempenho de uma célula a combustível se faz, geralmente, pelo estudo de sua curva de polarização, que relaciona o potencial da célula com a densidade de corrente [76].

As medidas de polarização foram realizadas em uma célula unitária ElectroChem com placas de grafite para distribuição do combustível do tipo serpentina $\left(5 \mathrm{~cm}^{2}\right.$ de área geométrica), com o oxigênio umidificado externamente usando uma garrafa umidificadora de temperatura controlada e aquecida a temperatura de $85{ }^{\circ} \mathrm{C}$. Foram realizados experimentos com uma pressão de 2 bar no cátodo, enquanto que o ânodo foi mantido à pressão atmosférica.

A temperatura da célula também foi ajustada para $100{ }^{\circ} \mathrm{C}$, sendo que 0 ânodo da célula foi alimentado com o álcool (metanol) na concentração de $2 \mathrm{~mol} \mathrm{~L}^{-1} \mathrm{com}$ um fluxo de, aproximadamente, $2 \mathrm{~mL} \mathrm{~min}^{-1}$. Os testes na célula unitária foram conduzidos em um painel de testes especialmente projetado, 
com carga dinâmica e multímetros da empresa Electrocell, onde se mediu o potencial da célula em função da densidade de corrente, com intervalo de $10 \mathrm{~s}$ de um ponto a outro. Os MEA's foram previamente ativados em testes de polarização com hidrogênio e oxigênio antes dos testes para a oxidação eletroquímica do metanol. 


\section{RESULTADOS E DISCUSSÃO}

\subsection{OXIDAÇÃO DO METANOL SOBRE HÍBRIDOS PtRu/CARBONO PREPARADOS POR CARBONIZAÇÃO HIDROTÉRMICA}

\subsubsection{Estudos das condições iniciais de síntese}

Estudos [109,110] mostram a importância do ajuste do $\mathrm{pH}$ do meio reacional de preparação de eletrocatalisadores na diminuição do tamanho de partículas, na melhor dispersão das nanopartículas no suporte de carbono e na melhora de desempenho dos eletrocatalisadores. Da mesma forma, estudos referentes à preparação de carbonos criogéis indicam a influência do uso de surfactantes na porosidade desses materiais [111]. Para avaliar a importância do ajuste do $\mathrm{pH}$ e o uso de surfactantes na preparação de eletrocatalisadores $\mathrm{PtRu} / \mathrm{C}$ pela carbonização hidrotérmica, inicialmente foram preparados eletrocatalisadores PtRu/C (50:50) com carga metálica* nominal de 5\% em massa usando amido como fonte de carbono e 6 horas de síntese. As sínteses foram realizadas nas seguintes condições: sem ajuste de $\mathrm{pH}$, na ausência e na presença de cloreto de tetrapropilamônio (TPACl), e ajustando o pH em torno de 11, através do uso de hidróxido de potássio $(\mathrm{KOH})$ ou hidróxido de tetrapropilamônio (TPAOH).

Nas condições de síntese, o amido, usado como fonte de carbono, é hidrolisado a unidades de glicose, as quais atuam como agente redutor dos íons metálicos, neste caso Pt(IV) e Ru(III), e estes, como catalisadores do processo de carbonização [32]. Quando a síntese é realizada em meio alcalino, ou seja, valores de $\mathrm{pH}$ acima de 9, ocorre a dissociação dos átomos de $\mathrm{H}$ dos grupos $\mathrm{OH}$ das moléculas de amido ou glicose [112] o que leva a uma melhor dispersão dos íons metálicos e a um menor tamanho de nanopartículas metálicas nos materiais obtidos após o processo de carbonização hidrotérmica.

\footnotetext{
*As primeiras sínteses de híbridos PtRu/Carbono foram realizadas com uma carga metálica nominal de $5 \%$ em massa para não haver desperdício de reagentes em catalisadores sem atividade. Mais adiante este texto abordará a influência da carga metálica na eletroatividade dos híbridos PtRu/Carbono preparados pela carbonização hidrotérmica.
} 
A TAB. 1 apresenta dados referentes aos híbridos PtRu/Carbono obtidos por carbonização hidrotérmica em diferentes condições de $\mathrm{pH}$, na presença e na ausência do íon tetrapropilamônio..

TABELA 1 - Dados de $\mathrm{pH}$ do meio reacional, razão atômica $\mathrm{Pt}: \mathrm{Ru}$, rendimento de carbonização, perda de massa nos tratamentos térmicos e carga metálica dos híbridos PtRu/Carbono obtidos por carbonização hidrotérmica.

\begin{tabular}{cccccc}
\hline Aditivo & $\begin{array}{c}\text { PH do meio } \\
\text { reacional }\end{array}$ & $\begin{array}{c}\text { Razão atômica } \\
\text { Pt:Ru } \\
\text { EDX }\end{array}$ & $\begin{array}{c}\text { Rendimento de } \\
\text { carbonização }\end{array}$ & $\begin{array}{c}\text { Perda de } \\
\text { massa }\end{array}$ & $\begin{array}{c}\text { Carga } \\
\text { metálica } \\
(\%)\end{array}$ \\
\hline- & 2,0 & $47: 53$ & 52 & 53 & (\%) \\
TPACI & 1,7 & $66: 34$ & 48 & 57 & 8 \\
KOH & 12,3 & $66: 34$ & 88 & 53 & 6 \\
TPAOH & 11,5 & $51: 49$ & 71 & 51 & 5 \\
\hline
\end{tabular}

Durante a preparação dos materiais, o pH de síntese ficou entre 1 e 3, sem ajuste do $\mathrm{pH}$ do meio reacional e entre 11 e 13 depois do ajuste com $\mathrm{KOH}$ ou TPAOH. Os valores de rendimento de carbonização estão na faixa de 52 a $88 \%$, sendo os maiores valores alcançados nas sínteses em meio alcalino. A perda de massa do material como-sintetizado, após os tratamentos térmicos, apresentou valores entre 51 e 57\%. Os materiais PtRu/C preparados por carbonização hidrotérmica e tratados termicamente, apresentaram valores de razão atômica $\mathrm{Pt}: \mathrm{Ru}$ determinados por EDX similares aos valores nominais. Durante o processo de carbonização hidrotérmica, nem todo o metal adicionado ao meio reacional é ancorado no material carbonáceo resultante. Uma parte dos metais pode estar ligada a espécies solúveis de material carbonáceo resultante da carbonização incompleta do carboidrato que são eliminadas durante o processo de filtração e lavagem do material. Por outro lado, durante os tratamentos térmicos, cerca de $50 \%$ do material carbonáceo é eliminado e, coincidentemente, os valores de carga metálica obtidos foram próximos aos valores nominais.

A FIG. 6 apresenta os espectros de infravermelho dos híbridos PtRu/Carbono após tratamento térmico. 


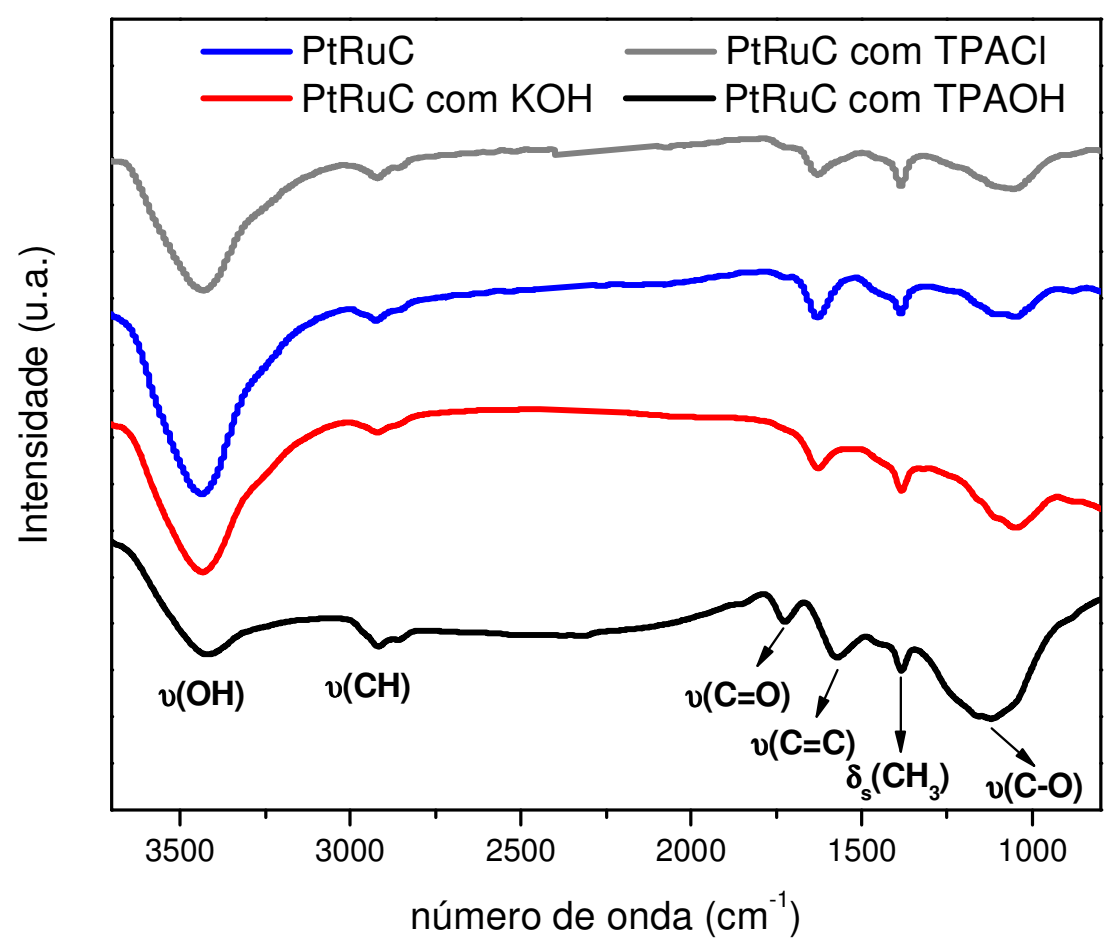

FIGURA 6 - Espectros de infravermelho dos híbridos PtRu/Carbono preparados por carbonização hidrotérmica e tratados termicamente.

Os espectros das quatro amostras são bastante similares entre si indicando que esses materiais possuem basicamente os mesmos grupos funcionais em sua superfície, ou seja, esses materiais possuem natureza química semelhante. A análise dos espectros revela a presença de grupos funcionais característicos de carbonos obtidos pelo método de carbonização hidrotérmica, tais como funções carbonila e hidroxila e ligações duplas alifáticas [31,95,97,113,114], como descrito a seguir: (i) a banda em, aproximadamente, $3400 \mathrm{~cm}^{-1}$ pode ser atribuída a vibrações $\mathrm{v}(\mathrm{O}-\mathrm{H})$ em grupos hidroxila, (ii) em $2900 \mathrm{~cm}^{-1}$ uma banda correspondente a vibrações $v_{s}(C-H)$ e $\mathrm{V}_{\mathrm{as}}(\mathrm{C}-\mathrm{H})$ de grupos metila e metileno, (iii) a banda em $1720 \mathrm{~cm}^{-1}$ é associada ao estiramento de ligações $\mathrm{C}=\mathrm{O}$ de grupos carboxílicos, (iv) vários trabalhos relacionam a banda em, aproximadamente, $1650 \mathrm{~cm}^{-1}$ ao estiramento das ligações $C=C$ da estrutura de carbono, mas Lua e Guo [115] associaram essa banda a vibrações $\mathrm{v}(\mathrm{C}=\mathrm{O})$ em quinonas (o grafite pode apresentar bandas de absorção nas regiões de vibração de estiramento do $\mathrm{C}=\mathrm{O}$ e do grupo $\mathrm{C}=\mathrm{C}$ de aromáticos) [114], (v) em, aproximadamente, $1375 \mathrm{~cm}^{-1}$ observa-se uma banda 
associada a deformação angular no plano do grupo metila $\left(\delta_{s}\left(\mathrm{CH}_{3}\right)\right)$ [113], (vi) a banda em $1460 \mathrm{~cm}^{-1}$ é devido a deformações angulares $\mathrm{O}-\mathrm{H}$ em grupos $\mathrm{COOH}$ e (vii) a banda na região de, aproximadamente, $1100-1050 \mathrm{~cm}^{-1}$ é atribuída à vibrações $\mathrm{v}(\mathrm{C}-\mathrm{O})$ em álcoois primários. Portanto, observa-se a presença de grupos funcionais oxigenados na superfície de todas as amostras.

Os difratogramas de raios-X dos híbridos PtRu/Carbono preparados por carbonização hidrotérmica e tratados termicamente são apresentados na FIG. 7.

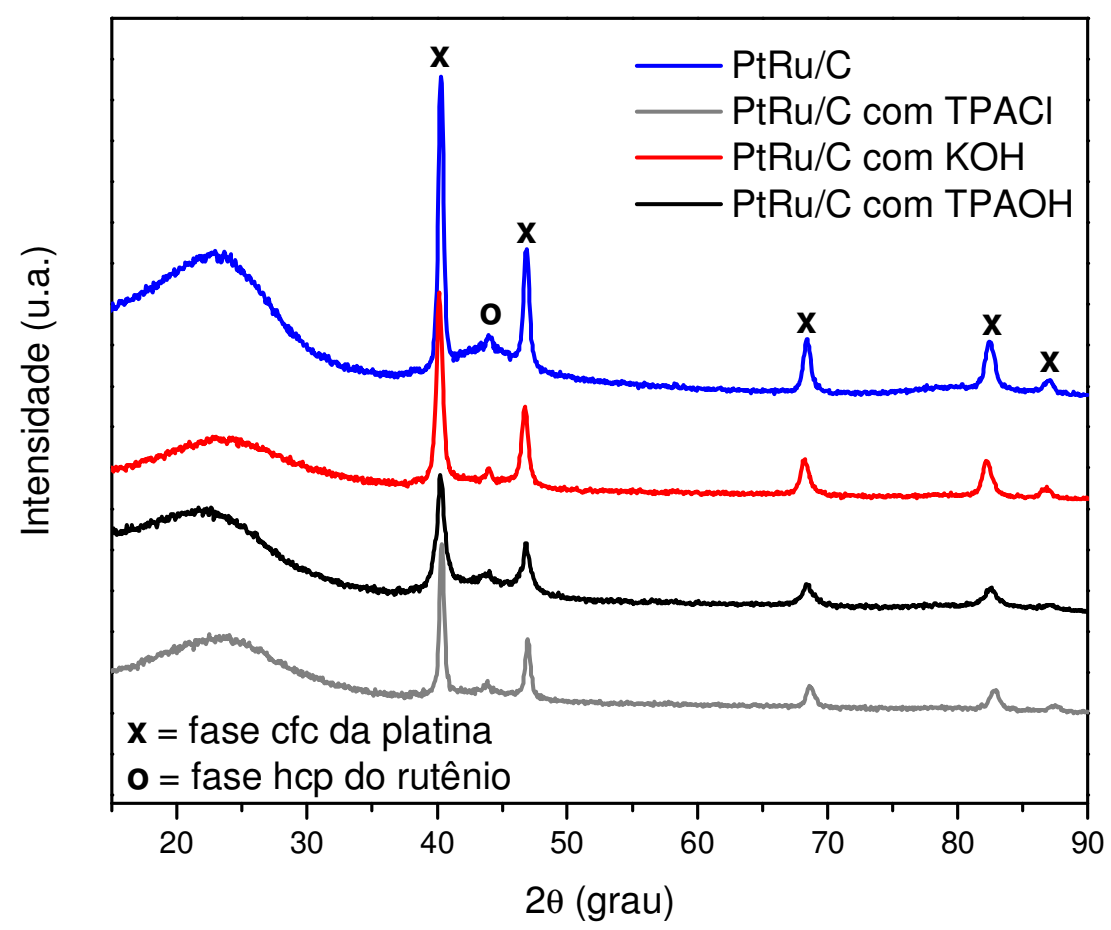

FIGURA 7 - Difração de raios-X das amostras PtRu/Carbono tratadas termicamente.

Todos os materiais PtRu/C apresentaram um pico largo em aproximadamente $2 \theta=23^{\circ}$, o qual é associado a estrutura de carbono, e cinco picos em, aproximadamente, $2 \theta=40^{\circ}, 47^{\circ}, 67^{\circ}, 82^{\circ}$ e $87^{\circ}$, os quais são associados aos planos (111), (200), (220), (311) e (222), respectivamente, da estrutura cúbica de face centrada (cfc) de platina e suas ligas [102,103,115]. Os valores de $2 \theta_{\text {max }}$ dos picos da fase $\mathrm{Pt}(\mathrm{cfc})$ apresentaram-se deslocados para maiores ângulos devido à incorporação de rutênio na rede cfc da platina e consequente contração da mesma. O pico em $2 \theta=44^{\circ}$ é atribuído à estrutura hexagonal 
compacta (hcp) do rutênio [102,116,117] que surge após os tratamentos térmicos, conforme observado em trabalhos anteriores [116]. Picos referentes a fases de $\mathrm{RuO}_{2}$ não foram observadas, entretanto a presença deste composto na sua forma amorfa é quase sempre possível em eletrocatalisadores PtRu/C $[103,118]$.

A TAB. 2 apresenta dados calculados a partir dos difratogramas de raios- $X$ como o tamanho médio de cristalito e o grau de liga bem como a área superficial, o volume de mesoporos e o volume total de poros obtidos através das isotermas de B.E.T..

TABELA 2 - Tamanho médio de cristalito, o grau de liga, área superficial, volume de mesoporos e volume total de poros dos híbridos PtRu/Carbono.

\begin{tabular}{|c|c|c|c|c|c|}
\hline Aditivo & $\begin{array}{l}\text { Tamanho } \\
\text { médio de } \\
\text { cristalito }^{1,2} \\
\text { (nm) }\end{array}$ & $\begin{array}{c}\text { Grau } \\
\text { de liga }^{1,3} \\
(\%)\end{array}$ & $\begin{array}{c}\text { Área } \\
\text { superficial } \\
\text { por } \mathrm{BET}^{1} \\
\left(\mathrm{~m}^{2} \mathrm{~g}^{-1}\right)\end{array}$ & $\begin{array}{c}\text { Volume de } \\
\text { mesoporos } \\
\left(\mathrm{cm}^{3} \mathrm{~g}^{-1}\right)\end{array}$ & $\begin{array}{c}\text { Volume } \\
\text { total } \\
\text { de poros } \\
\left(\mathrm{cm}^{3} \mathrm{~g}^{-1}\right)\end{array}$ \\
\hline- & 15 & 51 & 20 & 0,0317 & 0,032 \\
\hline TPACI & 13 & 35 & 233 & 0,0899 & 0,169 \\
\hline $\mathrm{KOH}$ & 14 & 66 & 28 & 0,0199 & 0,028 \\
\hline TPAOH & 12 & 47 & 117 & 0,0382 & 0,084 \\
\hline
\end{tabular}

'após os tratamentos térmicos, ${ }^{2}$ calculado pela Equação de Scherrer, ${ }^{3}$ calculado pela lei de Vegard.

O tamanho médio de cristalito estimado pela equação de Scherrer está na faixa de 12-15 nm. O grau de liga, calculado pela lei de Vegard, está na faixa de, aproximadamente, 45 a 65\%. Aparentemente, não existe um padrão do grau de liga com o pH, entretanto menores valores desse parâmetro foram encontrados nas amostras contendo o íon tetrapropilamônio indicando que, possivelmente, a presença de surfactante diminui o grau de formação de liga entre a platina e o rutênio, aumentando a quantidade de rutênio segregado.

Pelos dos dados de área superficial por BET, volume de mesoporos e volume total de poros (TAB. 1) pode-se inferir que os materiais preparados na ausência do íon tetrapropilamônio $\left(\mathrm{TPA}^{+}\right)$apresentaram valores de área superficial, volume de mesoporos e volume total de poros semelhantes, porém, menores que os obtidos para os materiais preparados na presença do íon 
$\mathrm{TPA}^{+}$. Portanto, a presença do íon $\mathrm{TPA}^{+}$colaborou para grandes incrementos da área superficial e na formação de uma estrutura de poros dos híbridos preparados pela carbonização hidrotérmica. Estes dados são concordantes com os obtidos por Tonanon e colaboradores [111] que estudaram a influência de surfactantes em carbonos criogéis sintetizados por policondensação sol-gel de resorcinol e formaldeído, onde observou-se que surfactantes catiônicos aumentam a porosidade de tais materiais. A diferença entre o volume total de poros e o volume de mesoporos é igual ao volume de microporos nas amostras.

Imagens obtidas por microscopia eletrônica de varredura dos híbridos $\mathrm{PtRu} / \mathrm{Carbono}$ tratados a $900{ }^{\circ} \mathrm{C}$, preparados em diferentes condições de $\mathrm{pH}$, na presença e na ausência do íon TPA ${ }^{+}$são apresentadas na FIG. 8a-d.

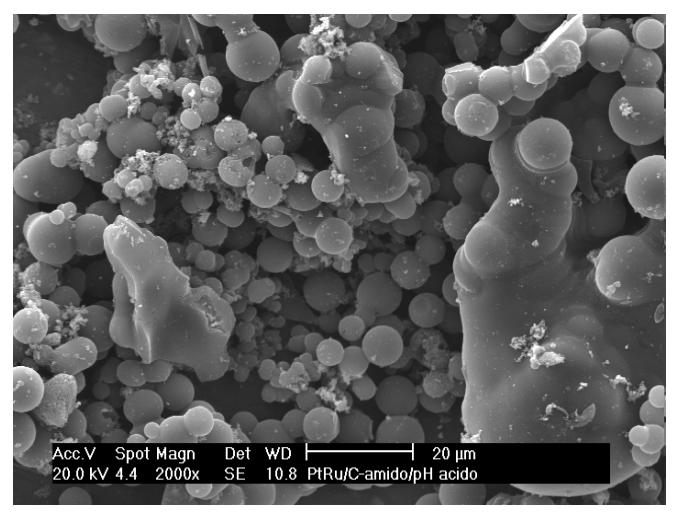

(a)

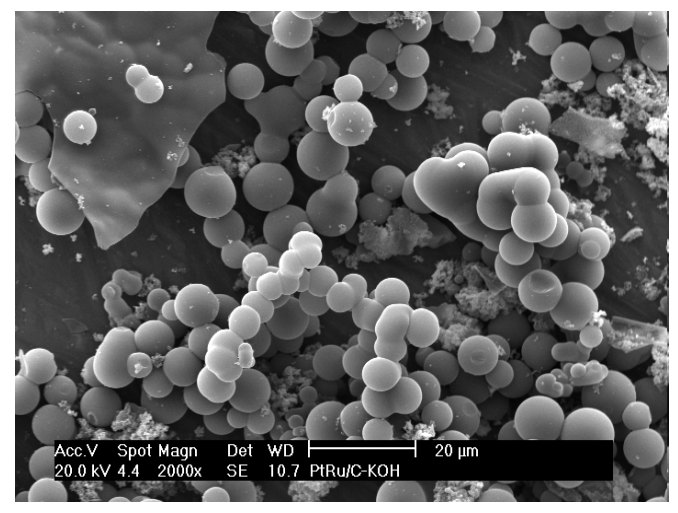

(c)

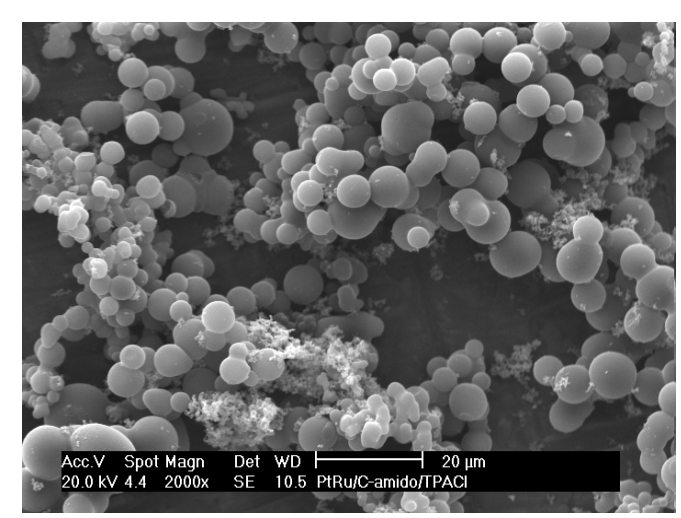

(b)

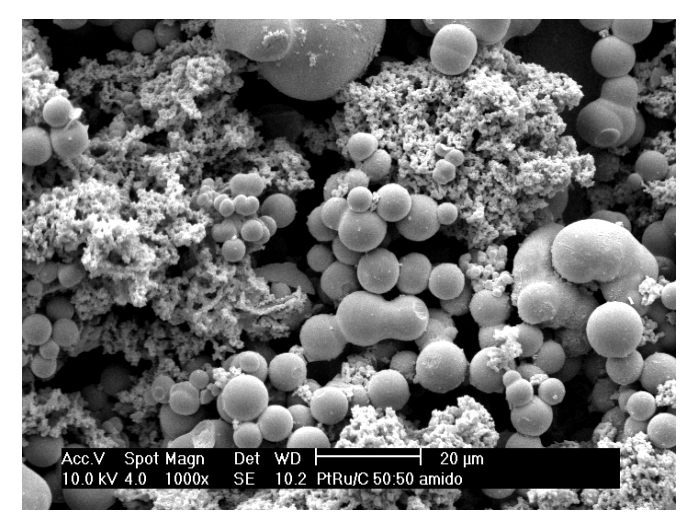

(d)

FIGURA 8 - Micrografias obtidas por microscopia eletrônica de varredura dos híbridos PtRu/Carbono, após tratamento térmico, preparados: (a) sem aditivo, (b) com TPACl, (d) com KOH e (e) com TPAOH. 
As micrografias revelam que todos os materiais $\mathrm{PtRu} / \mathrm{Carbono}$, independente do uso ou não de aditivos, apresentaram predominância da morfologia esférica, com algumas formas irregulares. Uma análise dos trabalhos envolvendo a síntese de carbonos e híbridos metal/carbono preparados por carbonização hidrotérmica mostra que a morfologia esférica é bastante comum nesses materiais [33,95,97,98]. Na carbonização hidrotérmica de carboidratos, um mecanismo de reação simplificado para a formação de esferas de carbono envolve, como primeira etapa, a desidratação do carboidrato em uma molécula com estrutura similar ao furano e, posteriormente, a polimerização e carbonização em soluções aquosas em temperaturas na faixa de 160-200 ${ }^{\circ} \mathrm{C}$ [97]. O crescimento de partículas de carbono derivados da carbonização hidrotérmica de glicose, sem a presença de metais, segue o modelo de LaMer em que sementes ou núcleos de carbono são formados durante o tratamento hidrotérmico e crescem uniformemente pela difusão de solutos para a superfície das partículas. $O$ aparecimento de formas irregulares durante a carbonização em presença de metais sugere que um mecanismo modificado, devido à ação catalítica das espécies metálicas (neste caso platina e rutênio), que ainda não é completamente compreendido deve ser considerado [33]. Provavelmente a ação catalítica das espécies metálicas está envolvida nos processos de polimerização e carbonização resultando em partículas de carbono com formas irregulares [33].

Outra explicação para o aparecimento da morfologia esférica diz que a baixas temperaturas (cerca de $160-200{ }^{\circ} \mathrm{C}$ ), os carboidratos começam a hidrolisar e se polimerizam para formar esferas de carbono com superfícies funcionalizadas e tamanho de, aproximadamente, $200 \mathrm{~nm}$ que é similar à síntese de esferas de carbono coloidal. Como a temperatura hidrotérmica aumenta, o movimento das esferas coloidais é acelerado, resultando em um sistema auto-organizado de esferas coloidais e na formação de agregados esféricos devido à tensão superficial [97]. Possíveis compostos aromáticos e oligomeros formados durante a reação podem adsorver-se em certas superfícies expostas das esferas coloidais para retardar seu crescimento e assim agregados não-esféricos são formados [97]. 
As micrografias obtidas por microscopia eletrônica de transmissão dos materiais PtRu/C preparados com TPACl, $\mathrm{KOH}$ e TPAOH, após tratamento térmico, são apresentados na FIG. 9.

(a)
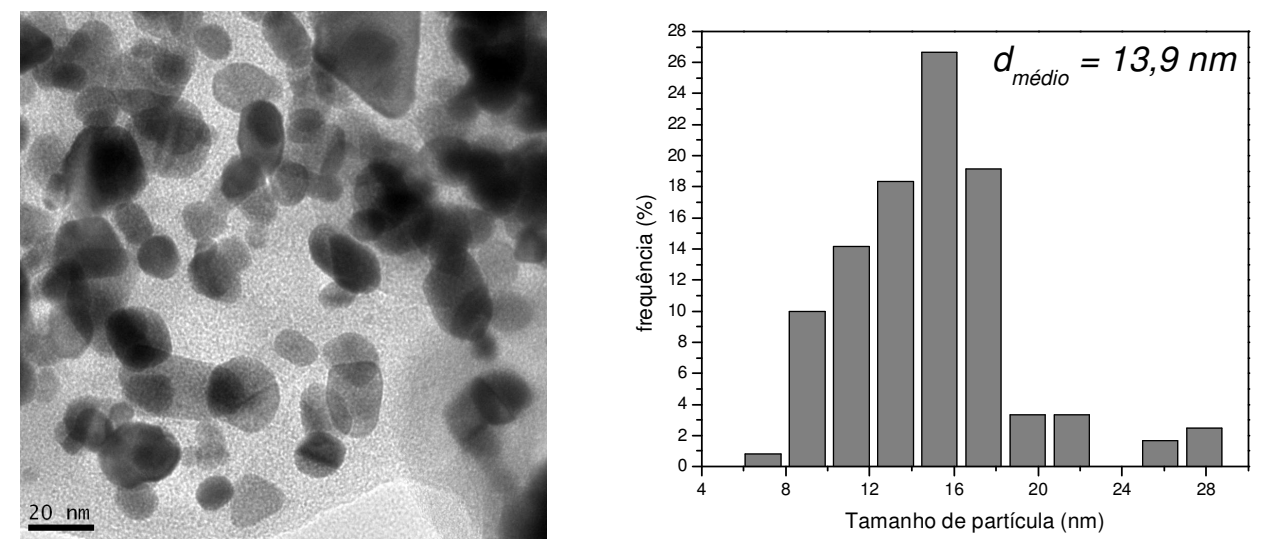

(b)
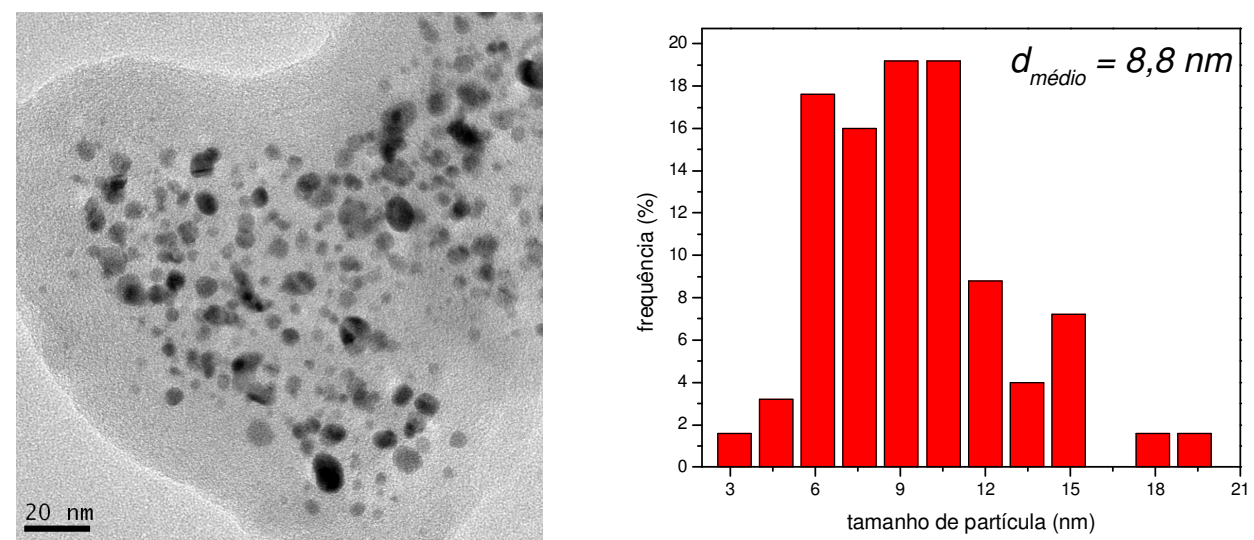

(c)
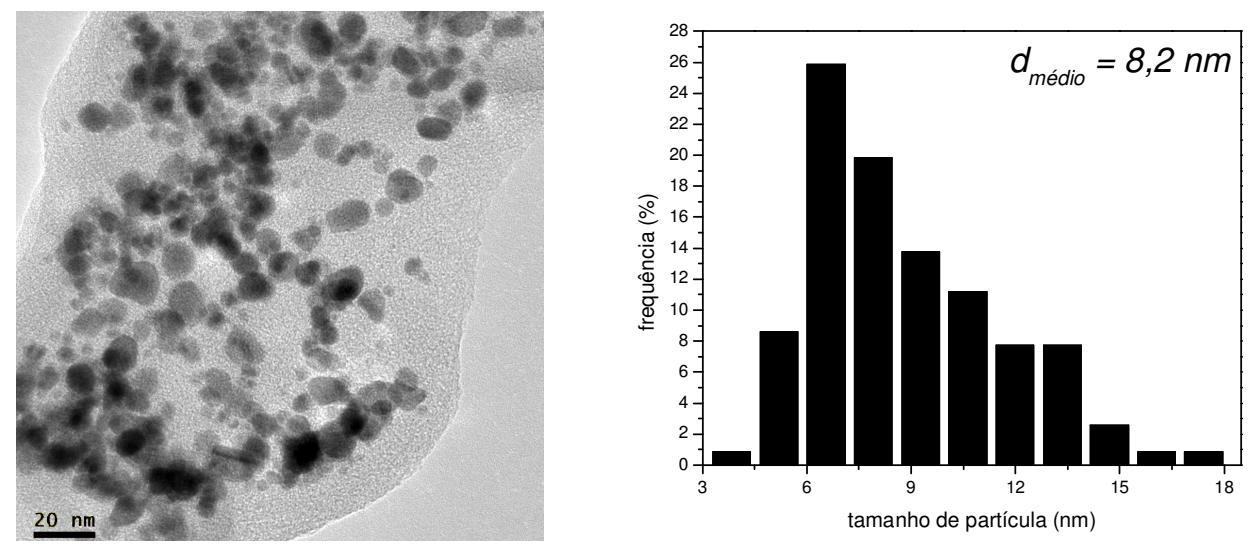

FIGURA 9 - Micrografias obtidas por microscopia eletrônica de transmissão e histogramas com a distribuição do tamanho de partículas dos materiais $\mathrm{PtRu} / \mathrm{C}$, após tratamento térmico, preparados com (a) TPACl (b) $\mathrm{KOH}$ e (c) TPAOH. 
As micrografias revelam que, nos três materiais, as nanopartículas metálicas estão razoavelmente dispersas no suporte de carbono. Os histogramas mostram um padrão monomodal de distribuição de tamanhos de partículas. Os tamanhos médio de partículas, calculados a partir das micrografias, foram de 13,9 nm para o PtRu/C - TPACl, 8,8 nm para o $\mathrm{PtRu} / \mathrm{C}-\mathrm{KOH}$ e 8,2 nm para o $\mathrm{PtRu} / \mathrm{C}$ - TPAOH. Portanto, o meio alcalino favorece um menor tamanho de partículas comparado com a síntese conduzida em meio ácido conforme encontrado na literatura [109-111]. O fato de o meio alcalino favorecer a menores tamanhos de partícula pode ser atribuído à estabilização eletroestérica das nanopartículas de PtRu por moléculas de glicose cujos grupos hidroxila perderam seu hidrogênio em função do alto pH [23]. Entendese por estabilização eletroestérica $[119,120]$ o fenômeno pelo qual moléculas relativamente grandes e carregadas (como moléculas de glicose desprotonadas) se adsorvem na superfície da nanopartícula mudando a densidade de carga da superfície da nanopartícula e impedindo a coalescência das nanopartículas pela associação dos fenômenos de repulsão eletrostática e impedimento estérico.

Experimentos eletroquímicos mostraram que os híbridos PtRu/Carbono como-sintetizados não apresentam atividade catalítica para a oxidação do metanol, provavelmente, devido ao material carbonáceo não apresentar uma boa condutividade eletrônica, além de possuir uma grande quantidade de grupos oxigenados que podem bloquear os sítios metálicos ativos. Após o tratamento a $900{ }^{\circ} \mathrm{C}$, ocorre uma organização na estrutura de carbono desses híbridos [101] resultando na melhora da condutividade eletrônica dos mesmos e, assim, tornando estes materiais ativos para a oxidação eletroquímica do metanol.

A FIG. 10 apresenta as voltametrias cíclicas em solução de $\mathrm{H}_{2} \mathrm{SO}_{4}$ para os materiais PtRu/Carbono tratados termicamente. 


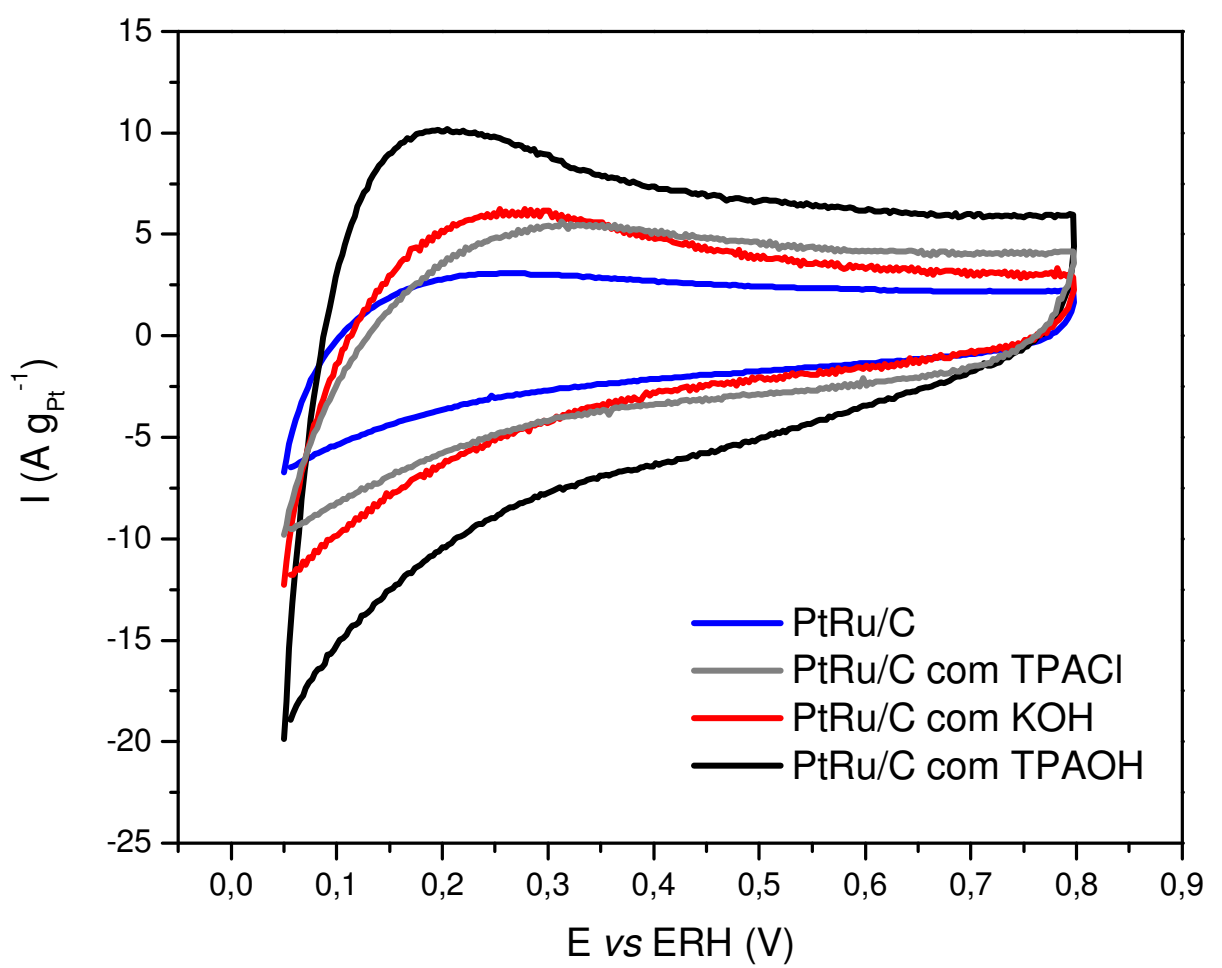

FIGURA 10 - Voltametria cíclica para os híbridos PtRu/Carbono em solução de $0,5 \mathrm{~mol} \mathrm{~L}^{-1}$ de $\mathrm{H}_{2} \mathrm{SO}_{4}$ e velocidade de varredura igual a $10 \mathrm{mV} \mathrm{s}^{-1}$.

Para todos os materiais, os voltamogramas cíclicos em meio ácido mostram a região adsorção-dessorção do hidrogênio $(0-0.4 \mathrm{~V})$ pouco definida e um alargamento na região de dupla camada $(0.4-0.8 \mathrm{~V})$, o que é característico de materiais com razão atômica Pt:Ru de 50:50 [24]. A inibição da adsorçãodessorção de hidrogênio deve-se, provavelmente, à incorporação de rutênio à estrutura da platina, assim como o aumento no valor das correntes da região de dupla camada elétrica devido às correntes capacitivas e processos redox do $\mathrm{RuO}_{2}[121,122]$. Este aumento de corrente pode ser atribuído à transição entre os estados de oxidação $R u(I I I)$ e $R u(I V)$. Devido à existência de diferentes estados de oxidação do rutênio na faixa de potenciais, óxidos de rutênio são capazes de adsorver grandes quantidades de espécies $\mathrm{OH}$ durante o processo de polarização. Esses óxidos de rutênio conseguem variados estados de oxidação do metal por meio de uma troca de próton com a solução (Equação 24) [122]:

$$
\mathrm{RuO}_{x}(\mathrm{OH})_{y}+\delta \mathrm{e}^{-}+\delta \mathrm{H}^{+} \leftrightarrow \mathrm{RuO}_{x-\delta}(\mathrm{OH})_{y+\delta}
$$


As cronoamperometrias da oxidação do metanol sobre os materiais PtRu/Carbono, após tratamento térmico, são dispostas na FIG. 11.

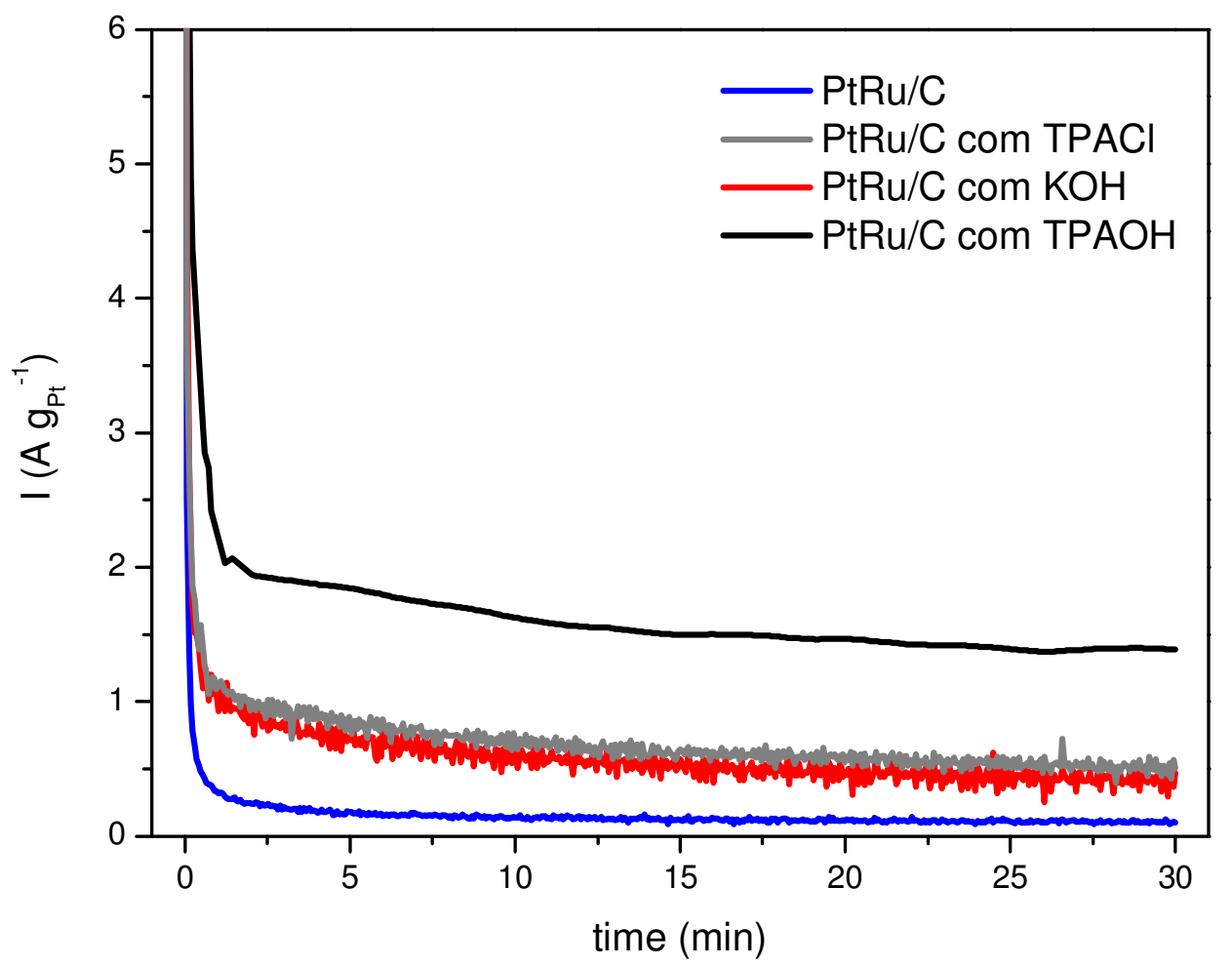

FIGURA 11 - Cronoamperometrias da oxidação do metanol sobre materiais PtRu/Carbono em solução de $0,5 \mathrm{~mol} \mathrm{~L}^{-1}$ de $\mathrm{H}_{2} \mathrm{SO}_{4}+1,0 \mathrm{~mol} \mathrm{~L}^{-1}$ de metanol em $0,5 \mathrm{~V}$, durante 30 minutos.

Os valores de corrente final, ou seja, a ordem de atividade eletrocatalítica dos materiais PtRu/Carbono para a oxidação do metanol após 30 minutos de aplicação de um potencial de $0,5 \mathrm{~V}$ versus $\mathrm{ERH}$ é a seguinte ordem: $\mathrm{PtRu} / \mathrm{C}$ $(\mathrm{TPAOH})>\mathrm{PtRu} / \mathrm{C}(\mathrm{TPACl})=\mathrm{PtRu} / \mathrm{C}(\mathrm{KOH})>\mathrm{PtRu} / \mathrm{C}$, sendo esta também a ordem de atividade catalítica. Aparentemente, a atividade eletrocatalítica desses materiais preparados pela carbonização hidrotérmica, em diferentes condições de $\mathrm{pH}$ e na presença e ausência de surfactante, é dependente de dois fatores: tamanho de partícula e estrutura de poros. Apesar de apresentar o maior volume de poros, o material PtRu/C (TPACI) possui o maior tamanho de partícula e, consequentemente, uma menor atividade eletrocatalítica. Os materiais PtRu/C (KOH) e PtRu/C (TPAOH) apresentam tamanhos de partícula semelhantes, porém valores de área superficial e volume total de poros 
bastante diferentes, sendo que o material preparado com TPAOH apresenta os maiores valores dessas propriedades resultando em um melhor desempenho para a oxidação eletroquímica do metanol. Materiais com menor tamanho de partícula são mais ativos devido ao fato de possuírem um maior número de átomos superficiais, ou seja, mais sítios ativos para a catálise da reação, além das propriedades eletrônicas do metal, número de coordenação dos átomos e interações nanopartícula-suporte serem afetadas pelo menor tamanho de partícula, fato este que pode favorecer a catálise de uma reação [123,124]. Da mesma forma, a estrutura de poros, principalmente a presença de mesoporos, influência na atividade catalítica devido à maior facilidade no transporte de reagentes e produtos, além de prover maior acesso aos sítios ativos [125,126].

Recapitulando, os híbridos PtRu/Carbono obtidos por carbonização hidrotérmica em diferentes condições de $\mathrm{pH}$ e na presença e ausência de surfactante, após os tratamentos térmicos, apresentaram razões atômicas e cargas metálicas similares aos valores nominais, além de grupos funcionais superficiais semelhantes. Os difratogramas desses materiais indicaram a presença de fases cfc da platina e hcp do rutênio. As diferentes condições de $\mathrm{pH}$ e o uso de surfactante mostraram uma grande influência na estrutura de poros e tamanho de partículas, resultando em materiais com diferentes atividades eletrocatalíticas. O material PtRu/Carbono preparado utilizando TPAOH para ajuste do $\mathrm{pH}$ do meio reacional apresentou a melhor atividade eletrocatalítica para a oxidação eletroquímica do metanol, possivelmente devido à sua estrutura de poros e menor tamanho de partículas.

\subsubsection{Estudo da razão atômica $\mathrm{Pt}: \mathrm{Ru}$}

Como já foi descrito, os sítios de platina removem os hidrogênios do grupo metila do metanol adsorvido em etapas consecutivas, resultando em um fragmento $\mathrm{Pt}-\mathrm{CO}$ que não pode ser oxidado a $\mathrm{CO}_{2}$ nos potenciais de uma DMFC. Este fragmento é oxidado com o auxílio de rutênio que adsorve água em potenciais menos positivos e realiza uma transferência de oxigênio, sendo este mecanismo denominado bifuncional. Segundo Long [68] quando se oxida metanol sobre eletrocatalisadores $\mathrm{PtRu} / \mathrm{C}$, surgem discrepâncias entre o mecanismo descrito acima e os dados experimentais. Embora o mecanismo prediga, e estudos com ligas bem-definidas verificam [127], que ligas ricas em 
platina são melhores para a oxidação do metanol (pelo fato da remoção de hidrogênios do metanol requerer muitos sítios de platina) os melhores desempenhos em DMFCs são alcançados com eletrocatalisadores $\mathrm{PtRu} / \mathrm{C}$ com razão atômica $\mathrm{Pt}: \mathrm{Ru}$ igual a 50:50. Assim, os resultados indicam que a razão atômica $\mathrm{Pt}: \mathrm{Ru}$ ótima é bastante dependente do método de preparação [9,20,23].

Por isso, neste estudo foram preparados, pelo método da carbonização hidrotérmica, híbridos PtRu/Carbono nas razões atômicas $\mathrm{Pt}: \mathrm{Ru}$ de (50:50), (60:40), (80:20) e (90:10) todos com carga metálica nominal de 5\% em massa, utilizando amido como fonte de carbono, hidróxido de tetrapropilamônio (TPAOH) para o ajuste do $\mathrm{pH}$ do meio reacional e 6 horas de síntese.

A TAB. 3 apresenta os dados referentes aos híbridos PtRu/Carbono preparados por carbonização hidrotérmica com diferentes razões atômicas.

TABELA 3 - Razão atômica Pt:Ru, rendimento de carbonização, perda de massa nos tratamentos térmicos, carga metálica, tamanho médio de cristalito dos híbridos PtRu/Carbono com diferentes razões atômicas $\mathrm{Pt}: \mathrm{Ru}$.

\begin{tabular}{ccccc}
\hline $\begin{array}{c}\text { Razão atômica } \\
\text { Pt:Ru } \\
\text { (nominal) }\end{array}$ & $\begin{array}{c}\text { Razão atômica } \\
\text { Pt:Ru } \\
\text { (EDX) }\end{array}$ & $\begin{array}{c}\text { Rendimento de } \\
\text { carbonização } \\
(\%)\end{array}$ & $\begin{array}{c}\text { Perda de } \\
\text { massa } \\
(\%)\end{array}$ & $\begin{array}{c}\text { Carga } \\
\text { metálica } \\
(\%)\end{array}$ \\
\hline $50: 50$ & $51: 49$ & 71 & 51 & 5 \\
$60: 40$ & $61: 39$ & 74 & 55 & 6 \\
$80: 20$ & $74: 26$ & 62 & 50 & 5 \\
$90: 10$ & $87: 13$ & 63 & 50 & 6 \\
\hline
\end{tabular}

De acordo com os dados da TAB. 3, as razões atômicas determinadas por EDX dos híbridos PtRu/Carbono com diferentes razões atômicas Pt:Ru obtidos por carbonização hidrotérmica e tratados termicamente foram similares aos valores nominais. Da mesma forma, as cargas metálicas desses materiais foram, razoavelmente, similares aos valores nominais. Os valores de rendimento de carbonização estão na faixa de $60-75 \%$, sendo os maiores valores registrados para as amostras mais ricas em rutênio. Os valores de perda de massa encontrados após os tratamentos térmicos foram na faixa de 50 a 55\%. 
A FIG. 12 apresenta os difratogramas de raios-X dos híbridos $\mathrm{PtRu} / \mathrm{Carbono}$, com diferentes composições, tratadas termicamente.

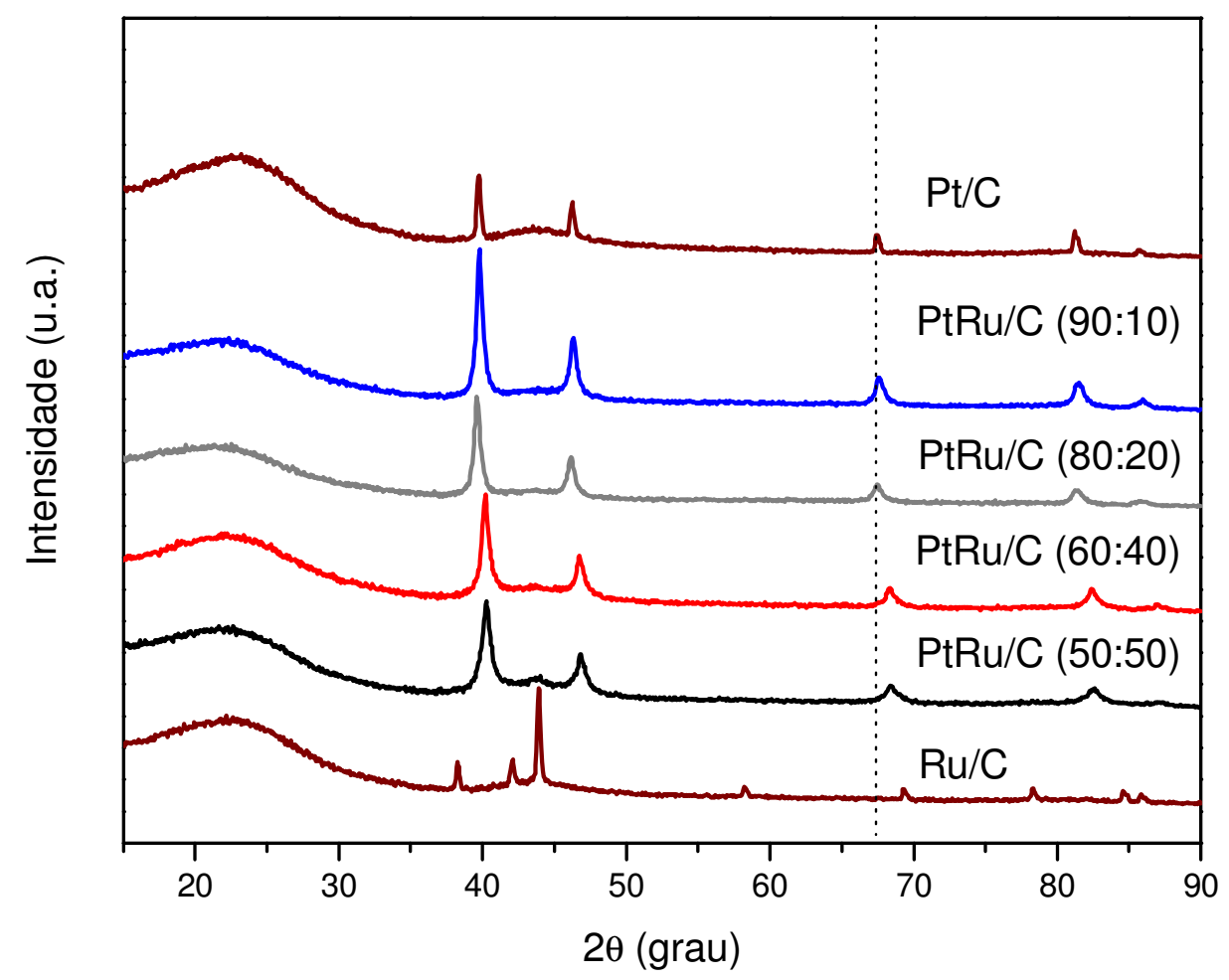

FIGURA 12 - Difratogramas de raios-X dos materiais PtRu/C, com diferentes composições, tratadas termicamente.

Os difratogramas de raios- $\mathrm{X}$ dos híbridos $\mathrm{PtRu} /$ Carbono apresentam um pico em, aproximadamente, $2 \theta=23^{\circ}$ associado ao carbono além de cinco picos em, aproximadamente, $2 \theta=40^{\circ}, 47^{\circ}, 67^{\circ}, 82^{\circ}$ e $87^{\circ}$ que são associados aos planos (111), (200), (220), (311) e (222), respectivamente, da estrutura cúbica de face centrada da platina e suas ligas [102,103,115]. Todos os materiais apresentaram um pico em, aproximadamente, $2 \theta=44^{\circ}$ que aumenta de intensidade com o aumento da quantidade de rutênio nas amostras. Este pico foi associado à fase segregada de rutênio metálico com estrutura hexagonal compacta [102,116,117]. O material Ru/Carbono apresentou quatro picos em, aproximadamente, $2 \theta=38^{\circ}, 42^{\circ}, 44^{\circ}, 58^{\circ}, 69^{\circ}, 78^{\circ}, 84^{\circ}$ e $86^{\circ}$ da estrutura hexagonal compacta do rutênio [117]. Picos referentes à $\mathrm{RuO}_{2}$ não foram observados indicando que este composto pode estar na fase amorfa [103,118]. 
A TAB. 4 apresenta dados sobre o tamanho médio de cristalito e o grau de liga calculados a partir dos difratogramas de raios-X para os materiais termicamente tratados PtRu/Carbono de composições variadas.

TABELA 4 - Tamanho de médio de cristalito e grau de liga para os híbridos PtRu/Carbono com diferentes composições após tratamento térmico

\begin{tabular}{|c|c|c|}
\hline $\begin{array}{c}\text { Razão atômica } \\
\text { Pt:Ru } \\
\text { (nominal) }\end{array}$ & $\begin{array}{c}\text { Tamanho médio } \\
\text { de cristalito } \\
(\mathrm{nm})\end{array}$ & $\begin{array}{c}\text { Grau de } \\
\text { liga }^{1,3} \\
\text { (\%) }\end{array}$ \\
\hline $50: 50$ & 12 & 47 \\
\hline $60: 40$ & 13 & 64 \\
\hline $80: 20$ & 11 & 10 \\
\hline $90: 10$ & 13 & 7 \\
\hline
\end{tabular}

Os tamanhos médios de cristalito calculados pela equação de Scherrer estão na faixa de 11-13 nm. O grau de liga nas amostras PtRu/Carbono preparadas com diferentes razões $\mathrm{Pt}: \mathrm{Ru}$ tem seu maior valor para o material com razão atômica Pt:Ru de 60:40 e o menor valor para o híbrido com razão atômica de 90:10. Aparentemente, apenas pode-se afirmar que quanto maior o teor de rutênio nos híbridos, maior a probabilidade deste elemento encontrar-se na forma de liga. Entretanto, o valor máximo de rutênio encontrado na forma de liga está em torno dos $50 \%$.

Os voltamogramas cíclicos, em meio ácido, dos híbridos PtRu/Carbono com diferentes composições são apresentados na FIG. 13. 


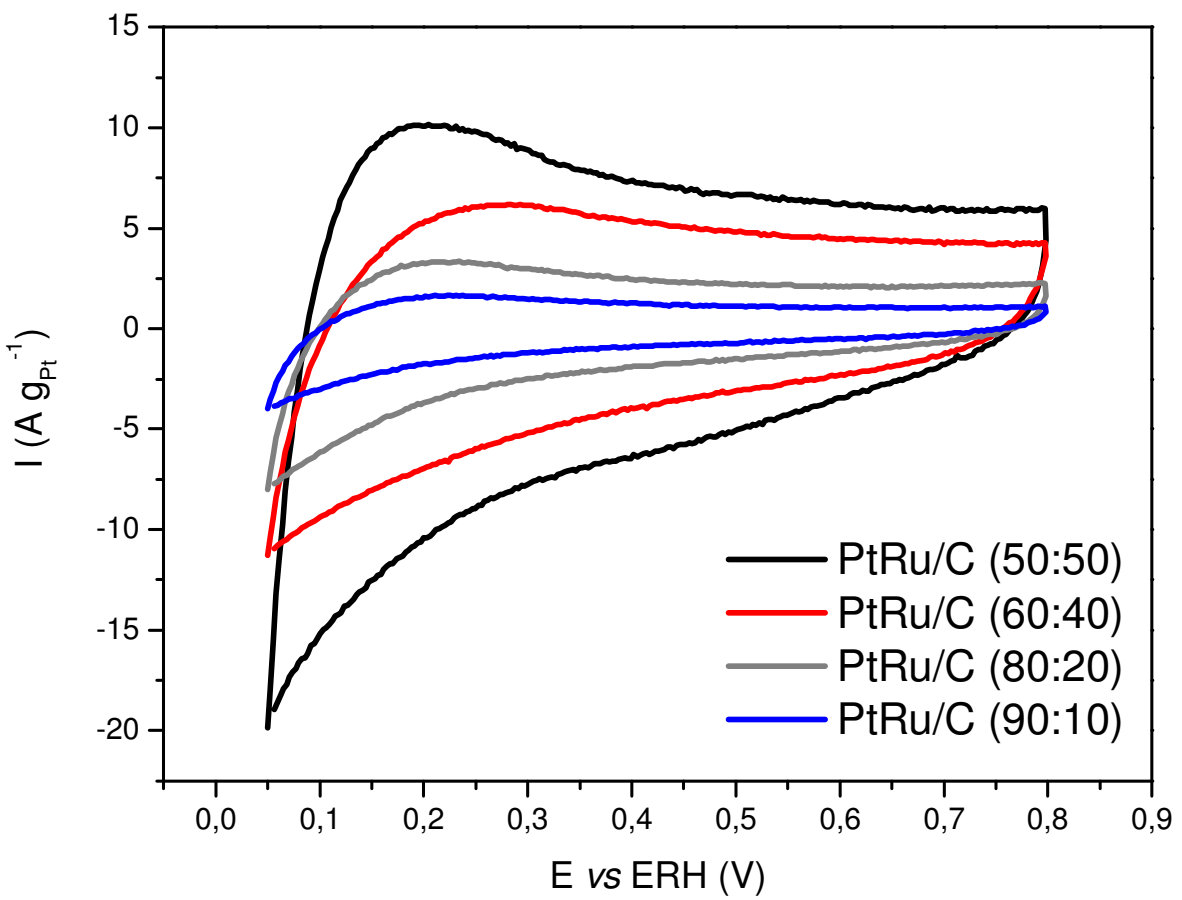

FIGURA 13 - Voltametria cíclica dos materiais PtRu/C com diferentes composições em solução de $0,5 \mathrm{~mol} \mathrm{~L}^{-1}$ de $\mathrm{H}_{2} \mathrm{SO}_{4}$ e velocidade de varredura igual a $10 \mathrm{mV} \mathrm{s}^{-1}$.

Todos os materiais apresentaram uma região de adsorção-desorção de hidrogênio $(0.05-0.4 \mathrm{~V})$ pouco definida conforme observado para ligas de platina [24]. Também foi observado um alargamento na região de dupla camada elétrica $(0.4-0.8 \mathrm{~V})$ proporcional ao aumento do teor de rutênio nos materiais. Esse aumento nos valores de corrente na região de dupla camada elétrica pode ser atribuído ao aumento de óxidos de rutênio e os efeitos que isso acarreta conforme discutido anteriormente [121,122]. Segundo Profeti [122] o comportamento voltamétrico de um eletrocatalisador depende do conteúdo de platina: uma melhor definição dos picos de adsorção-dessorção de hidrogênio e menores correntes na região de dupla camada elétrica são observados para altos teores de platina. Por outro lado, os picos de hidrogênio não são bem-definidos e as correntes na região da dupla camada são maiores no caso de baixos teores de platina, ou seja, maiores quantidades de rutênio. $O$ aumento nos valores de corrente na região da dupla camada elétrica indica que sítios de rutênio são expostos à solução contribuindo no comportamento 
eletroquímico superficial e na sua capacidade de adsorver grandes quantidades de espécies $\mathrm{OH}$.

Os voltamogramas cíclicos da oxidação do metanol sobre os híbridos PtRu/Carbono com diferentes composições dos híbridos são apresentados na FIG. 14.

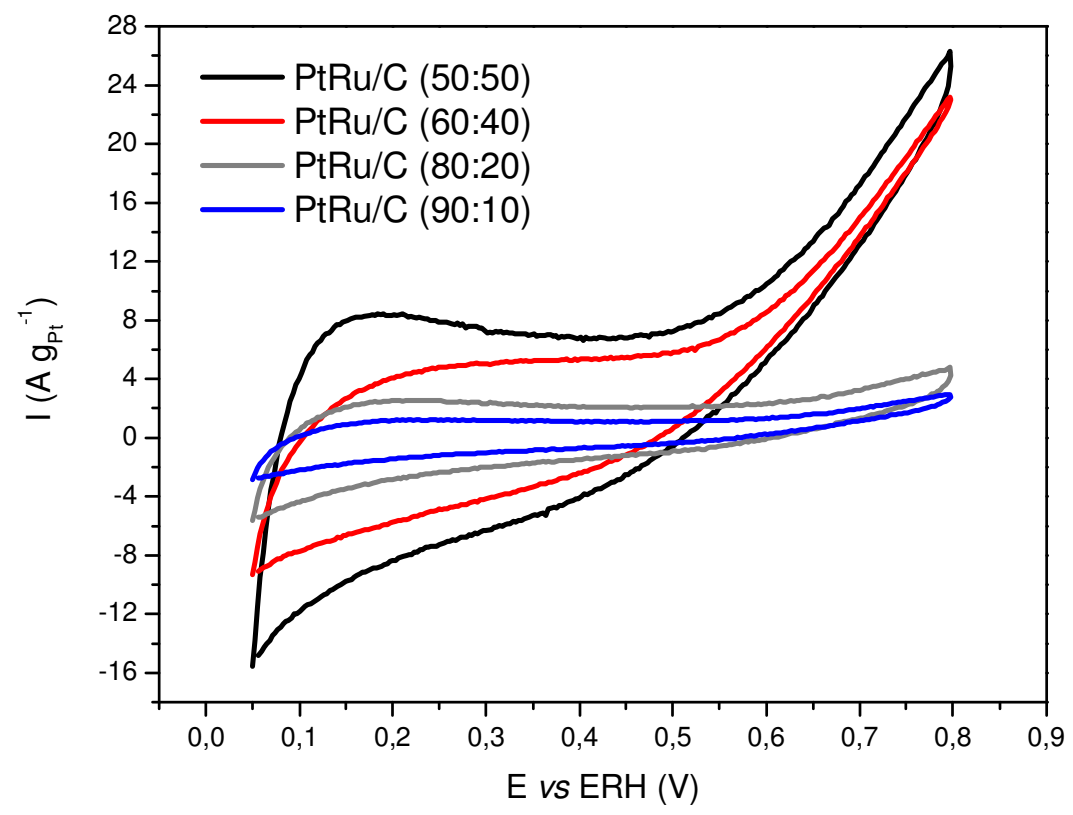

FIGURA 14 - Voltametria cíclica, para a oxidação do metanol sobre os híbridos PtRu/Carbono com diferentes composições, em solução de $0,5 \mathrm{~mol} \mathrm{~L}^{-1}$ de $\mathrm{H}_{2} \mathrm{SO}_{4}+1,0 \mathrm{~mol} \mathrm{~L}^{-1}$ de metanol e velocidade de varredura igual a $10 \mathrm{mV} \mathrm{s}^{-1}$.

Quando em presença de 1,0 mol L-1 de metanol, os híbridos PtRu/Carbono com razão atômica Pt:Ru igual a 50:50 e 60:40, ou seja, os materiais contendo maior quantidade de rutênio apresentam as maiores atividades eletrocatalíticas para a oxidação eletroquímica do metanol comparados aos eletrocatalisadores com menor teor de rutênio, sendo que o material PtRu/Carbono com razão atômica Pt:Ru de 50:50 apresentou os maiores valores de corrente em toda a faixa de potenciais.

As cronoamperometrias, em solução de $0,5 \mathrm{~mol} \mathrm{~L}^{-1}$ de $\mathrm{H}_{2} \mathrm{SO}_{4}$ contendo $1,0 \mathrm{~mol} \mathrm{~L}^{-1}$ de metanol, para a oxidação do metanol sobre os híbridos PtRu/Carbono com diferentes razões atômicas são dispostas na FIG. 15. 


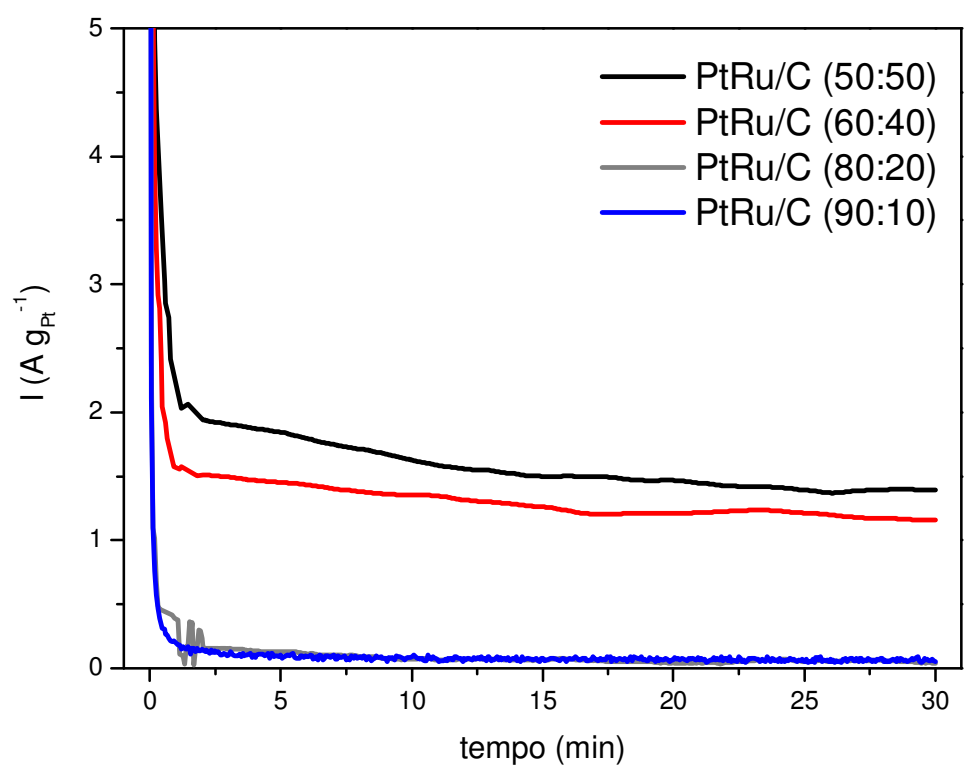

FIGURA 15 - Cronoamperometrias para a oxidação do metanol sobre os híbridos PtRu/Carbono com diferentes razões atômicas, em solução de $0,5 \mathrm{~mol} \mathrm{~L}^{-1}$ de $\mathrm{H}_{2} \mathrm{SO}_{4}$ contendo $1,0 \mathrm{~mol} \mathrm{~L}^{-1}$ de metanol em $0,5 \mathrm{~V}$ durante 30 minutos.

Assim como observado por voltametria cíclica, o híbrido PtRu/Carbono (50:50) seguido do PtRu/Carbono (60:40) apresentaram as maiores atividades eletrocatalíticas para a oxidação eletroquímica do metanol., enquanto as amostras com baixo teor de rutênio apresentaram uma baixa atividade catalítica. Tal resultado pode ser explicado em função do grau de liga e da quantidade de rutênio segregado. O híbrido PtRu/Carbono (60:40) possui um maior grau de liga que a amostra PtRu/Carbono (50:50), ou seja, o híbrido mais rico em rutênio possui também uma maior quantidade de rutênio segregado. Embora não tenha sido observado nos difratogramas de raios-X, provavelmente os materiais PtRu/Carbono (50:50) e (60:40) possuem fases de $\mathrm{RuO}_{2}$ e/ou $\mathrm{RuO}_{x} \mathrm{H}_{y}$, sendo, possivelmente, estas fases mais abundantes na amostra com maior teor de rutênio segregado. Trabalhos [68,128-131] indicam que o $\mathrm{RuO}_{x} \mathrm{H}_{\mathrm{y}}$ possui um efeito benéfico na oxidação eletroquímica do metanol, desempenhando um importante papel em uma DMFC, pois este composto possui uma mistura dos estados de oxidação (III) e (IV), além de ser capaz de conduzir prótons e elétrons e expressar a especiação de $\mathrm{Ru}-\mathrm{OH}$ (Equação 25) [68]: 


$$
\mathrm{Ru}^{\mathrm{IV}}-\mathrm{O}^{2-}+\mathrm{H}^{+} \rightarrow \mathrm{Ru}{ }^{\mathrm{II}}-\mathrm{OH}
$$

Equação 25

Os dados apresentados neste trabalho vão contra os observados por Aricò [132], onde foi verificado que os eletrocatalisadores com maiores graus de liga são os mais ativos para a oxidação do metanol. Entretanto, os dados deste trabalho estão de acordo com o relatado por Long [68], Rolison [128] e Lu $[129,130]$, onde o efeito da presença de $\mathrm{RuO}_{\mathrm{x}} \mathrm{H}_{\mathrm{y}}$ foi mensurado mais importante que o grau de liga. Tal discussão baseia-se no fato de que parte do rutênio segregado encontra-se na forma amorfa de $\mathrm{RuO}_{\mathrm{x}} \mathrm{H}_{\mathrm{y}}$, entretanto tal fato somente poderia confirmar-se por meio de técnicas de caracterização superficial como, por exemplo, a espectroscopia fotoeletrônica de raios-X (XPS).

Portanto, os híbridos PtRu/Carbono preparados por carbonização hidrotérmica com diferentes razões atômicas $\mathrm{Pt}: \mathrm{Ru}$ apresentaram valores de razão atômica Pt:Ru e cargas metálicas similares aos valores nominais. Os difratogramas de raios- $X$ dessas amostras mostraram picos referentes às fases cfc da platina e hcp do rutênio, sendo que os picos da fase de rutênio aumentaram em intensidade proporcionalmente ao teor de rutênio. $\mathrm{Na}$ avaliação dos híbridos PtRu/Carbono para oxidação do metanol, o material preparado com razão atômica Pt:Ru de 50:50 apresentou a melhor atividade eletrocatalítica, seguido do material com razão atômica Pt:Ru igual a 60:40. Como o grau de liga do PtRu/Carbono (50:50) é menor que do material com razão de (60:40), acredita-se que o primeiro possui atividade superior pela presença de $\mathrm{RuO}_{x} \mathrm{H}_{y}$, conforme relatado em vários artigos.

\subsubsection{Estudo da fonte de carbono}

Um estudo preliminar [116] mostrou que a fonte de carbono influência fortemente na atividade catalítica de híbridos PtRu/Carbono preparados pela carbonização hidrotérmica. No intuito de melhor observar esse parâmetro, foram preparados eletrocatalisadores $\mathrm{PtRu} / \mathrm{C}$ com razôes atômicas de 50:50, utilizando glicose, amido e celulose como fontes de carbono, sendo o $\mathrm{pH}$ do meio ajustado pelo uso de TPAOH com tempo e temperatura de síntese de 6 horas e $200 \stackrel{\circ}{\mathrm{C}}$ respectivamente. 
Os dados de razão atômica Pt:Ru, rendimento de carbonização e perda de massa nos tratamentos térmicos e carga metálica dos híbridos PtRu/Carbono, preparados com diferentes fontes de carbono, são apresentados na TAB. 5.

TABELA 5 - Razão atômica Pt:Ru, rendimento de carbonização, perda de massa nos tratamentos térmicos e carga metálica dos híbridos PtRu/Carbono (50:50) preparados com diferentes fontes de carbono.

\begin{tabular}{|c|c|c|c|c|}
\hline $\begin{array}{l}\text { Fonte de } \\
\text { carbono }\end{array}$ & $\begin{array}{c}\text { Razão atômica } \\
\text { Pt:Ru } \\
\text { EDX }\end{array}$ & $\begin{array}{c}\text { Rendimento de } \\
\text { carbonização } \\
(\%)\end{array}$ & $\begin{array}{c}\text { Perda de } \\
\text { massa } \\
(\%)\end{array}$ & $\begin{array}{c}\text { Carga } \\
\text { metálica } \\
(\%)\end{array}$ \\
\hline glicose & $58: 42$ & 75 & 51 & 4 \\
\hline amido & $51: 49$ & 71 & 51 & 5 \\
\hline celulose & $56: 44$ & 66 & 59 & 6 \\
\hline
\end{tabular}

Os valores de razão atômica Pt:Ru, determinados por EDX, e carga metálica, determinados por análise termogravimétrica, dos híbridos PtRu/Carbono preparados por carbonização hidrotérmica com uso de diferentes fontes de carbono, após os tratamentos térmicos, foram similares aos valores nominais. Os valores de rendimento de carbonização estão na faixa de 65-75\%, na ordem glicose > amido > celulose, ou seja, diminuindo à medida que aumenta a complexidade molecular da fonte de carbono. As perdas de massa após os tratamentos térmicos foram semelhantes com valores na faixa de 51-59\%.

A FIG. 16 apresenta os espectros de infravermelho dos híbridos PtRu/Carbono preparados com diferentes fontes de carbono, após tratamento térmico. 


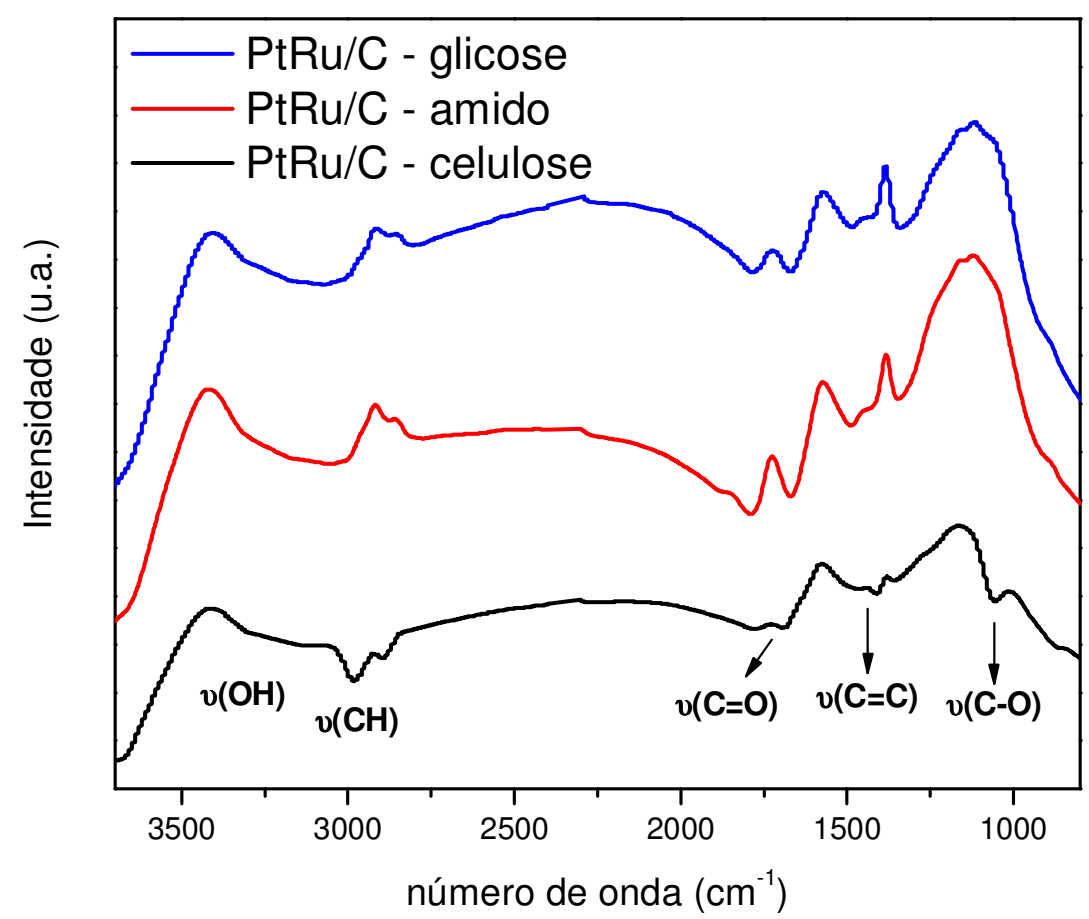

FIGURA 16 - Espectros de infravermelho dos híbridos PtRu/Carbono preparados com diferentes fontes de carbono, após tratamento térmico.

Os espectros de infravermelho dos híbridos PtRu/Carbono preparados com diferentes fontes de carbono, após os tratamentos térmicos, são bastante semelhantes entre si indicando que esses materiais possuem basicamente os mesmos grupos funcionais em sua superfície, ou seja, esses materiais possuem uma natureza química semelhante e estão de acordo com o observado para materiais carbonosos preparados pela carbonização hidrotérmica $[31,95,97,113,114]$. Os espectros apresentaram as seguintes bandas: (i) aproximadamente, em $3400 \mathrm{~cm}^{-1}$ atribuída a vibrações $\mathrm{v}(\mathrm{O}-\mathrm{H}) \mathrm{em}$ grupos hidroxila, (ii) em $2900 \mathrm{~cm}^{-1}$, banda associada a vibrações $v_{s}(C-H)$ e $v_{\text {as }}(\mathrm{C}-\mathrm{H})$ de grupos metila e metileno, (iii) em $1720 \mathrm{~cm}^{-1}$ associada ao estiramento de ligações $\mathrm{C}=\mathrm{O}$ de grupos carboxílicos, (iv) em, aproximadamente, $1650 \mathrm{~cm}^{-1}$ associado ao estiramento das ligações $\mathrm{C}=\mathrm{C}$ da estrutura de carbono ou a vibrações $\mathrm{v}(\mathrm{C}=\mathrm{O})$ em quinonas [115], (v) em, aproximadamente, $1375 \mathrm{~cm}^{-1}$ observa-se uma banda associada a deformação angular no plano do grupo metila $\left(\delta_{s}\left(\mathrm{CH}_{3}\right)\right)$ [113], (vi) em $1460 \mathrm{~cm}^{-1}$ é devido à deformações angulares $\mathrm{O}-\mathrm{H}$ em grupos $-\mathrm{COOH}$ e (vii) a banda na região de, aproximadamente, $1100-1050 \mathrm{~cm}^{-1}$ é atribuída à vibrações $\mathrm{v}(\mathrm{C}-\mathrm{O})$ em álcoois 
primários. Portanto, novamente observa-se a presença de grupos funcionais oxigenados na superfície de todas as amostras.

A FIG. 17 apresenta os difratogramas de raios-X dos híbridos $\mathrm{PtRu} /$ Carbono, preparados com diferentes fontes de carbono, tratados termicamente.

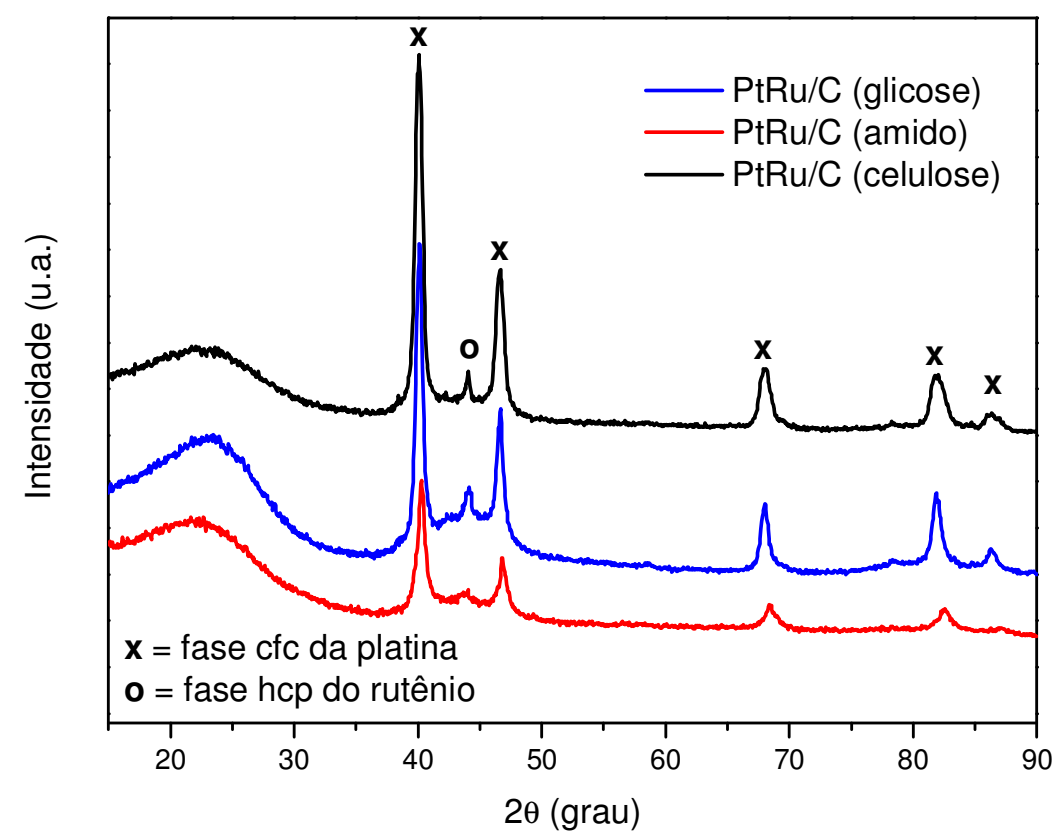

FIGURA 17 - Difratogramas de raios-X dos híbridos PtRu/Carbono, preparados com diferentes fontes de carbono, tratadas termicamente.

Os difratogramas dos materiais PtRu/Carbono apresentaram um pico em, aproximadamente, $2 \theta=23^{\circ}$ associado ao material de carbono e cinco picos em, aproximadamente, $2 \theta=40^{\circ}, 47^{\circ}, 67^{\circ}, 82^{\circ}$ e $87^{\circ}$ característicos da estrutura cúbica de face centrada da platina e suas ligas [102,103,115]. Todas as amostras apresentaram um pico em, aproximadamente, $2 \theta=44^{\circ}$ que foi atribuído a fase segregada de rutênio metálico com estrutura hexagonal compacta [102,116,117]. Não foram observados picos referentes à $\mathrm{RuO}_{2}$ indicando que este material pode estar presente na amostra na fase amorfa [103,118].

A TAB. 6 apresenta dados calculados a partir dos difratogramas de raios-X como o tamanho médio de cristalito, o parâmetro de rede e o grau de liga, além dos valores de área superficial, volume de mesoporos e volume total 
de poros obtidos por B.E.T. para os híbridos termicamente tratados $\mathrm{PtRu} /$ Carbono preparados com diferentes fontes de carbono.

TABELA 6 - Tamanho médio de cristalito, grau de liga, área superficial, volume de mesoporos e volume total de poros dos híbridos PtRu/Carbono (50:50) preparados com diferentes fontes de carbono.

\begin{tabular}{cccccc}
\hline $\begin{array}{c}\text { Fonte de } \\
\text { carbono }\end{array}$ & $\begin{array}{c}\text { Tamanho } \\
\text { de cristalito } \\
(\mathbf{n m})\end{array}$ & $\begin{array}{c}\text { Grau de } \\
\text { liga } \\
(\%)\end{array}$ & $\begin{array}{c}\text { Área } \\
\text { superficial } \\
\text { por BET } \\
\left(\mathbf{m}^{2} \mathbf{~ g}^{-1}\right)\end{array}$ & $\begin{array}{c}\text { Volume de } \\
\text { mesoporos } \\
\left(\mathbf{c m}^{3} \mathbf{g}^{-1}\right)\end{array}$ & $\begin{array}{c}\text { Volume total } \\
\text { de poros } \\
\left(\mathbf{c m}^{3} \mathbf{~ g}^{-1}\right)\end{array}$ \\
\hline glicose & 11 & 31 & 50 & 0,01 & 0,048 \\
amido & 12 & 47 & 117 & 0,038 & 0,084 \\
celulose & 8 & 13 & 76 & 0,250 & 0,260 \\
\hline
\end{tabular}

Os tamanhos médios de cristalitos dos materiais PtRu/Carbono calculados pela equação de Scherrer encontram-se na faixa de 8-12 nm. Os valores de grau de ligas das amostras PtRu/Carbono, preparados com diferentes fontes de carbono, apresentaram-se na faixa de $13-47 \%$, sendo o maior valor registrado para o material preparado com amido. Portanto, a celulose favorece um menor valor do tamanho médio de cristalito com um menor grau de liga, sendo que, aparentemente, relações entre grau de liga e a fonte de carbono não podem ser feitas. A área superficial por BET do material preparado usando glicose foi $50 \mathrm{~m}^{2} \mathrm{~g}^{-1}$ e este valor aumenta para $117 \mathrm{~m}^{2} \mathrm{~g}^{-1}$ quando foi utilizado amido como fonte de carbono. Usando celulose, o valor diminui para $76 \mathrm{~m}^{2} \mathrm{~g}^{-1}$. Entretanto, o volume total de poros do material preparado usando celulose foi maior que aqueles observados quando se utiliza amido e glicose. Além disso, o volume total de poros do material preparado com celulose mostrou que era formado quase exclusivamente por mesoporos, enquanto os materiais preparados com glicose ou amido possuem um pequeno volume de mesoporos.

Imagens obtidas por microscopia eletrônica de varredura dos materiais PtRu/Carbono preparados por carbonização hidrotérmica com diferentes fontes de carbono e tratados termicamente são apresentadas na FIG. 18. 


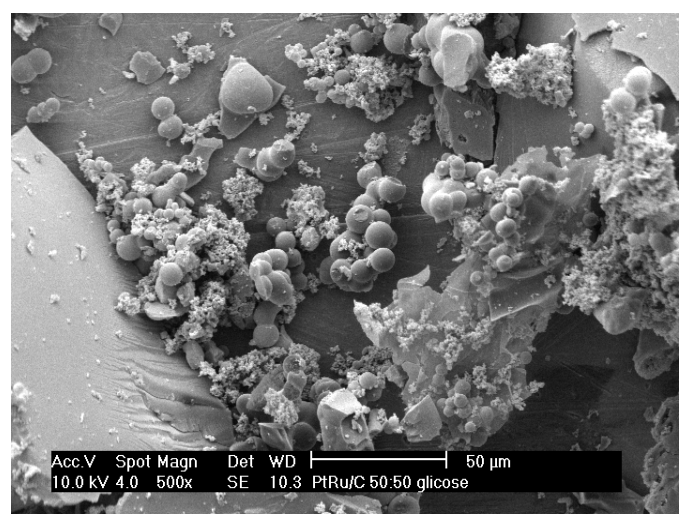

(a)

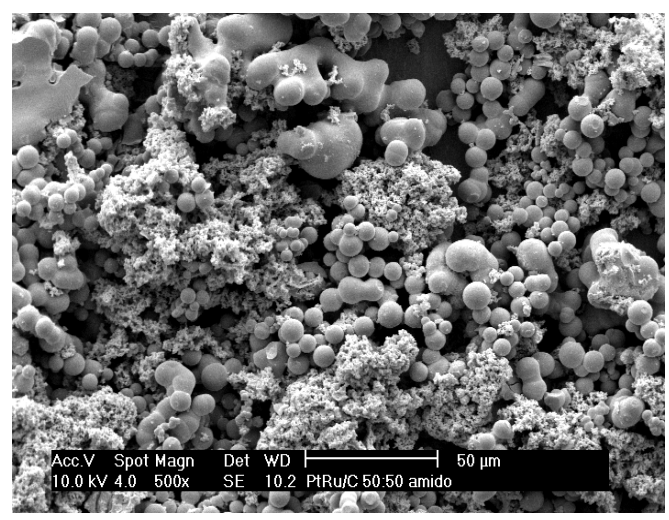

(b)

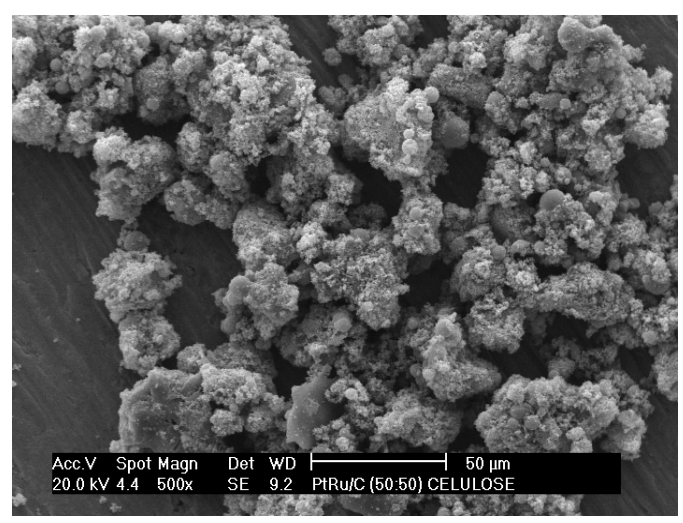

(c)

FIGURA 18 - Micrografias obtidas por microscopia eletrônica de varredura dos materiais PtRu/Carbono, tratados termicamente, preparados usando (a) glicose, (b) amido e (c) celulose.

A micrografia obtida por microscopia eletrônica de varredura do material PtRu/C preparado usando glicose mostra um material com morfologia predominantemente irregular com a presença de algumas formas esféricas (FIG. 18a), enquanto o material preparado usando amido apresentou predominância da forma esférica (FIG. 18b). O uso de celulose como fonte de carbono resulta na formação de aglomerados irregulares com estrutura de poros (FIG. 18c).

A FIG. 19 apresenta micrografias obtidas por microscopia eletrônica de transmissão dos materiais PtRu/Carbono tratados termicamente. 


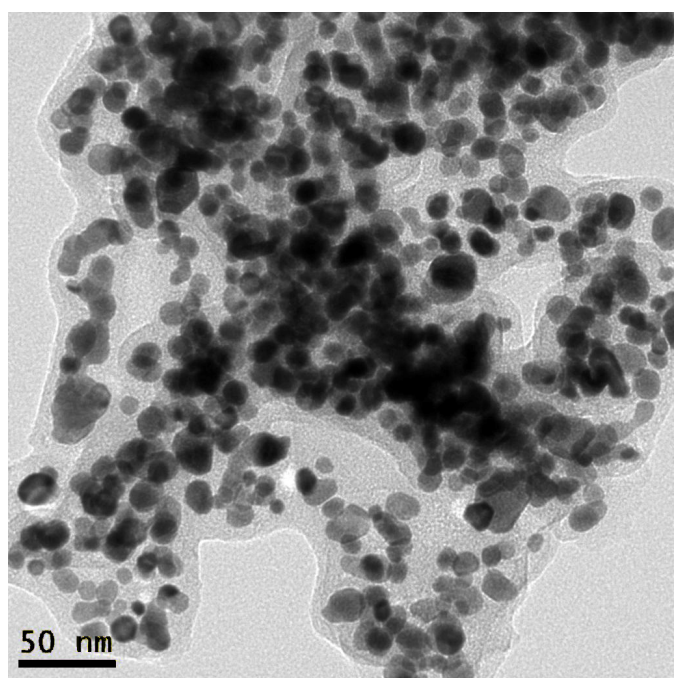

(a)

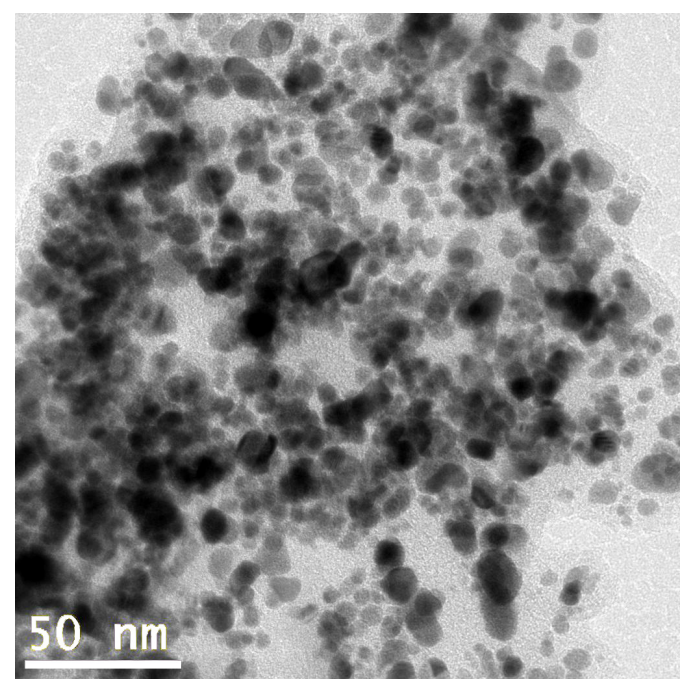

(b)

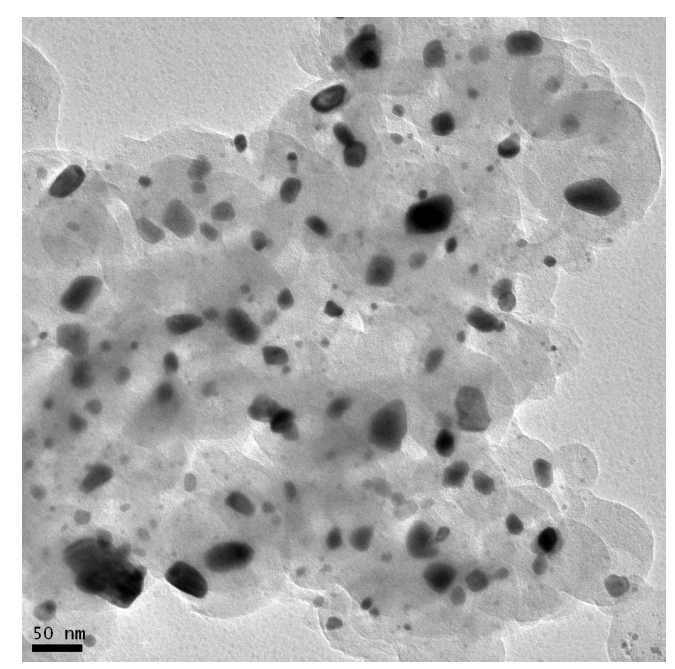

(c)

FIGURA 19 - Micrografias obtidas por microscopia eletrônica de transmissão dos materiais PtRu/Carbono, tratados termicamente, preparados usando (a) glicose, (b) amido e (c) celulose.

As imagens obtidas por microscopia eletrônica de transmissão revelam que os híbridos PtRu/Carbono preparados com diferentes fontes de carbono possuem nanopartículas metálicas razoavelmente dispersas no suporte de carbono. Aparentemente, as nanopartículas metálicas encontram-se encapsuladas por carbono, sendo que tal encapsulamento ocorre em maior escala na amostra preparada com glicose (FIG. 19a), seguida da amostra preparada com amido (FIG. 19b), enquanto no material preparado usando celulose, as nanopartículas encontram-se mais dispersas e, aparentemente, mais expostas na superfície 
do carbono (FIG. 19c). Os tamanhos médio de partículas, calculados a partir das micrografias, foram de $13,0 \mathrm{~nm}$ para o PtRu/C - glicose, 8,2 nm para o $\mathrm{PtRu} / \mathrm{C}$ - amido e 7,7 nm para o PtRu/C - celulose. Aparentemente, quanto maior a complexidade molecular da fonte de carbono, menor é o tamanho das nanopartículas metálicas. Possivelmente, uma explicação para esse resultado seja uma estabilização eletroestérica mais eficiente por parte da celulose, seguido do amido e, por último, da glicose. Isso deve-se justamente ao fato de o efeito estérico ser dependente da estrutura e complexidade da molécula adsorvida à nanopartícula bem como da espessura da camada formada por essas moléculas adsorvidas [119,120].

As cronoamperometrias da oxidação do metanol sobre híbridos PtRu/Carbono são apresentados na FIG. 20.

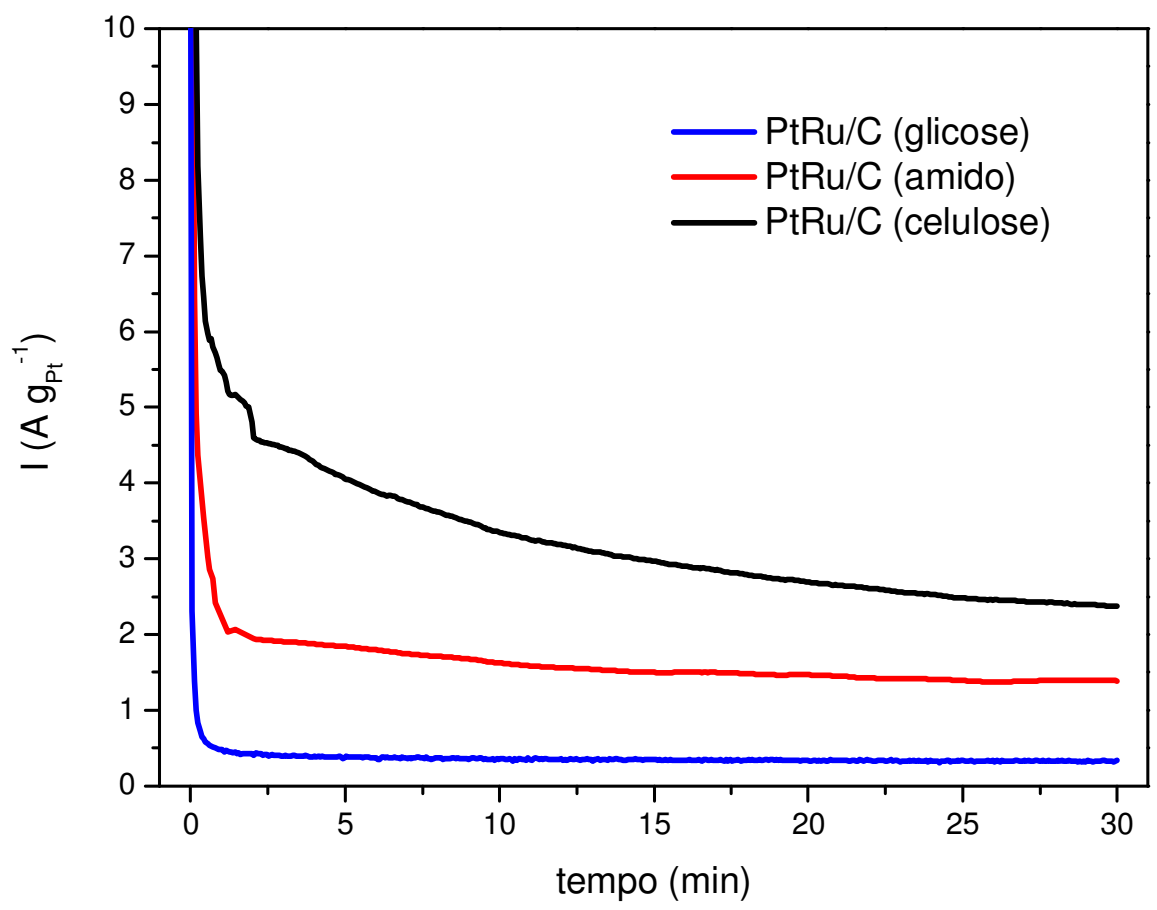

FIGURA 20 - Cronoamperometrias da oxidação do metanol sobre híbridos PtRu/Carbono, preparados com diferentes fontes de carbono, em solução de $0,5 \mathrm{~mol} \mathrm{~L}^{-1}$ de $\mathrm{H}_{2} \mathrm{SO}_{4}$ contendo $1,0 \mathrm{~mol} \mathrm{~L}^{-1}$ de metanol mediante aplicação de $0.5 \mathrm{~V}$ por 30 minutos.

A seguinte ordem de atividade para a oxidação eletroquímica do metanol foi observada para os híbridos PtRu/Carbono preparados com diferentes fontes de 
carbono: celulose $>$ amido > glicose, entretanto os materiais a base de amido e glicose mostraram-se mais estáveis ao longo do tempo comparado ao material preparado utilizando celulose como fonte de carbono. Várias são as possíveis explicações para a melhor atividade eletrocatalítica do híbrido PtRu/Carbono na oxidação eletroquímica do metanol, todos já discutidos anteriormente: menor tamanho das nanopartículas metálicas [123,124], maior volume de mesoporos e volume total de poros consistindo em uma maior estrutura de poros disponível $[125,126]$ e maior quantidade de rutênio segregado com a presença bastante provável do $\mathrm{RuO}_{x} \mathrm{H}_{\mathrm{y}}$ [68,128-131]. Estudos adicionais seriam necessários a fim de elucidar a extensão da influência de cada um desses efeitos nesses híbridos, sendo que nada mais conclusivo se pode afirmar com bases nos dados apresentados.

No estudo da influência da fonte de carbono na atividade eletrocatalítica de híbridos PtRu/Carbono preparados pela carbonização hidrotérmica, os materiais sintetizados apresentaram razões atômicas Pt:Ru e cargas metálicas similares aos valores nominais. As amostras apresentaram espectros de infravermelho semelhantes indicando que, independente da fonte de carbono, todas as amostras apresentam grupos funcionais oxigenados em suas superfícies, caracterizando naturezas químicas semelhantes. A difração de raios-X dos materiais mostrou a presença de fases cfc da platina e hcp de rutênio, sendo que o grau de liga (calculado a partir dos difratogramas pela lei de Vegard) apresentou seu menor valor para o híbrido preparado com celulose. As imagens de microscopia eletrônica de transmissão mostraram materiais cujas nanopartículas encontram-se razoavelmente dispersas na fonte de carbono, sendo que a ordem do tamanho médio de partículas foi glicose > amido $>$ celulose e as isotermas de B.E.T. indicaram que o material preparado a partir da celulose é o que possui maior volumes de mesoporos e total. Por fim, experimentos eletroquímicos revelaram que o híbrido PtRu/Carbono a base de celulose possui a maior atividade eletrocatalítica para a oxidação do metanol, possivelmente, devido ao menor tamanho de partículas, estrutura de poros disponível e pela maior presença de rutênio segregado. 


\subsubsection{Estudo da carga metálica}

Até esta parte do trabalho, todos os híbridos PtRu/Carbono preparados tinham carga metálica nominal igual a $5 \%$ em massa por motivos já explicados anteriormente. Entretanto, trabalhos [134-137] indicam que eletrocatalisadores $\mathrm{PtRu} / \mathrm{C}$ contendo alta carga metálica favorecem a oxidação eletroquímica do metanol, além do fato do catalisador comercial PtRu/C da E-TEK, referência na área, possuir carga metálica de $20 \%$.

Portanto, neste estudo foram preparados, pelo método da carbonização hidrotérmica, híbridos PtRu/Carbono com razão atômica Pt:Ru de (50:50) e com cargas metálicas nominais de $5 \%, 10 \%$ e $20 \%$ em massa, utilizando celulose como fonte de carbono, hidróxido de tetrapropilamônio (TPAOH) para o ajuste do $\mathrm{pH}$ do meio reacional e 6 horas de síntese.

Dados referentes aos híbridos PtRu/Carbono preparados por carbonização hidrotérmica com diferentes cargas metálicas são apresentados na TAB. 7.

TABELA 7 - Razões atômicas Pt:Ru, rendimentos de carbonização, perdas de massa após tratamentos térmicos e cargas metálicas dos híbridos PtRu/Carbono (50:50) com diferentes cargas metálicas preparados por carbonização hidrotérmica e tratados termicamente.

\begin{tabular}{ccccc}
\hline $\begin{array}{c}\text { Carga metálica } \\
\text { nominal }\end{array}$ & $\begin{array}{c}\text { Razão } \\
\text { atômica Pt:Ru } \\
(\%)\end{array}$ & $\begin{array}{c}\text { Rendimento de } \\
\text { carbonização }\end{array}$ & $\begin{array}{c}\text { Perda de } \\
\text { massa }\end{array}$ & $\begin{array}{c}\text { Carga metálica } \\
\text { TGA }\end{array}$ \\
\hline 5 & $56: 44$ & $(\%)$ & $(\%)$ & $(\%)$ \\
10 & $50: 50$ & 66 & 59 & 6 \\
20 & $56: 44$ & 60 & 57 & 15 \\
\hline
\end{tabular}

Os valores de razão atômica $\mathrm{Pt}: \mathrm{Ru}$ dos híbridos $\mathrm{PtRu} / \mathrm{Carbono,} \mathrm{preparados} \mathrm{por}$ carbonização hidrotérmica e tratados termicamente, determinados por EDX foram similares aos valores nominais. Os valores de carga metálica, determinados por análise termogravimétrica (FIG. 21), dos híbridos $\mathrm{PtRu} /$ Carbono preparados por carbonização hidrotérmica, após os tratamentos térmicos, mostraram discrepâncias comparados aos valores nominais, exceto no caso do híbrido com carga metálica de $5 \%$ em massa. Nos híbridos com 
cargas metálicas nominais de $10 \%$ e $20 \%$ houve uma discrepância em torno de $50 \%$ a mais do que o valor esperado (nominal). Os valores de rendimento de carbonização foram na faixa de $60-66 \%$, sendo que quanto maior a carga metálica menor o valor desse parâmetro, contrariando as expectativas uma vez que uma maior concentração de metais deveria favorecer mais a carbonização, aumentando o seu rendimento. Os valores de perda de massa encontrados foram em torno de 53-59\%, diminuindo de acordo com o aumento da carga metálica, indicando que a maior concentração de metais exerce um pequeno favorecimento na carbonização e, portanto, diminuindo levemente a perda de material carbonoso, oriundo da carbonização incompleta, durante os tratamentos térmicos.

As curvas TG das amostras com diferentes cargas metálicas são apresentados na FIG. 21 apenas para fins ilustrativos.

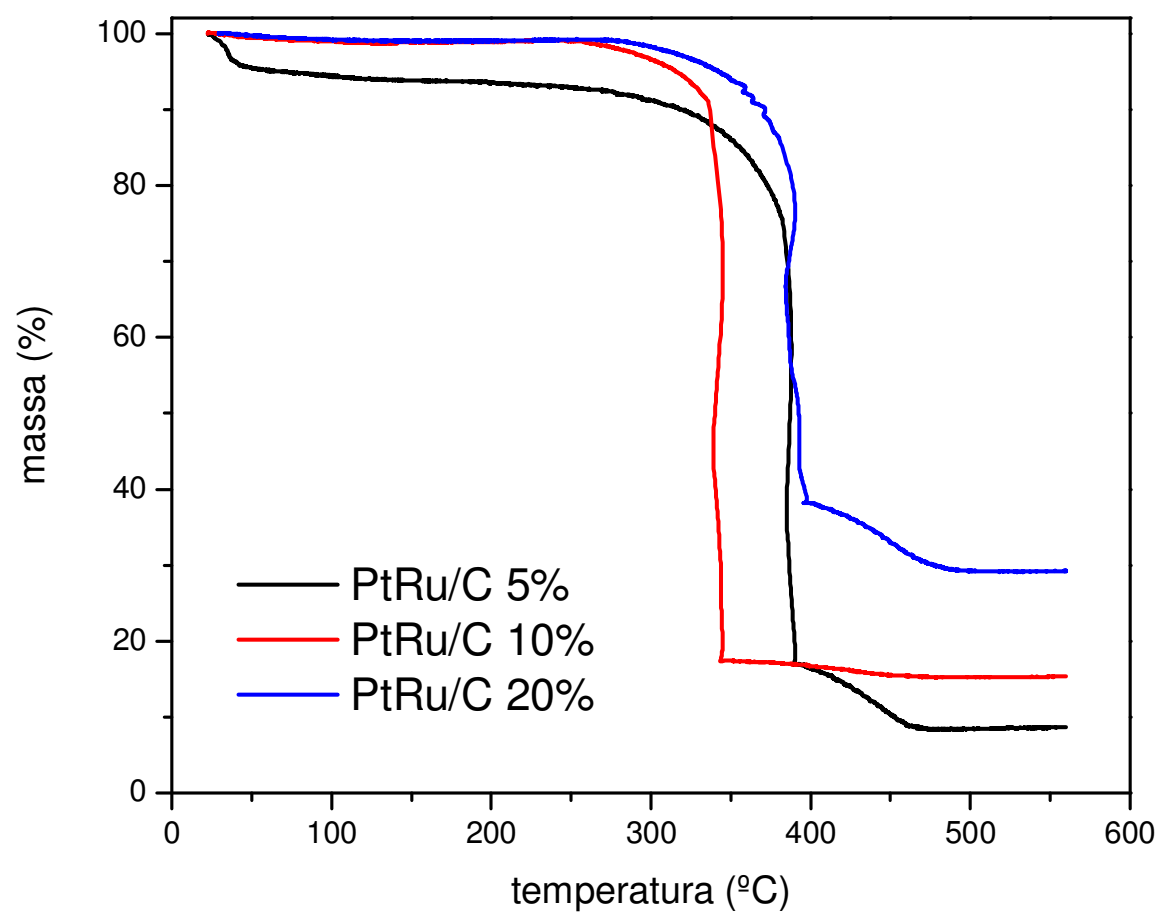

FIGURA 21 - Curvas TG dos híbridos PtRu/Carbono preparados por carbonização hidrotérmica com diferentes cargas metálicas, após tratamentos térmicos.

Portanto este será o único termograma apresentado uma vez que o dado principal desta técnica é o valor de carga metálica disponibilizado nas tabelas. 
Os difratogramas de raios- $\mathrm{X}$ dos híbridos $\mathrm{PtRu}$ /Carbono preparados com diferentes cargas metálicas nominais são apresentados na FIG. 22.

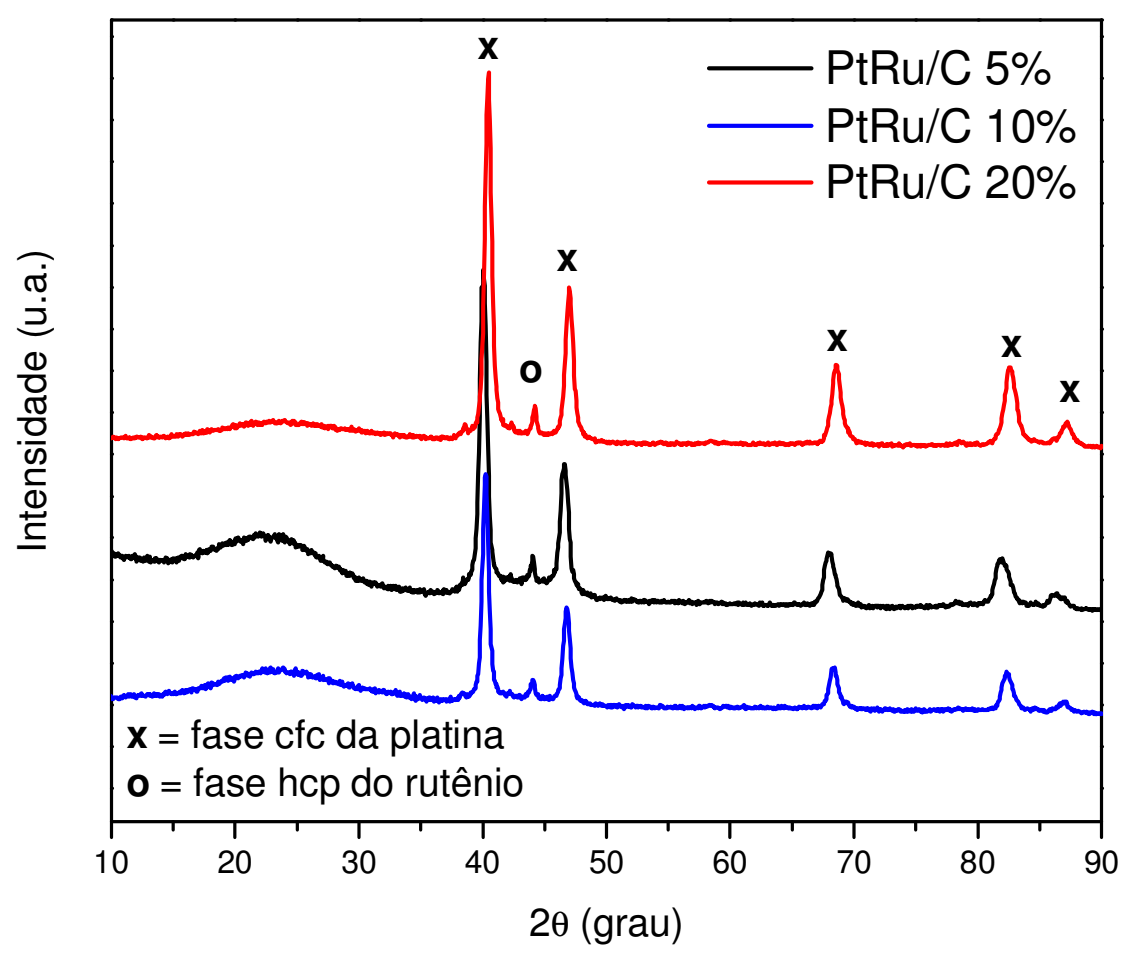

FIGURA 22 - Difratogramas de raios-X dos híbridos PtRu/Carbono preparados com diferentes cargas metálicas nominais pela carbonização hidrotérmica e tratados termicamente.

Os difratogramas dos materiais PtRu/Carbono com diferentes cargas metálicas apresentaram um pico em, aproximadamente, $2 \theta=23^{\circ}$ associado ao material de carbono e cinco picos em, aproximadamente, $2 \theta=40^{\circ}, 47^{\circ}, 67^{\circ}, 82^{\circ} \mathrm{e}$ $87^{\circ}$ característicos da estrutura cúbica de face centrada da platina e suas ligas [102,103,115]. Todas as amostras apresentaram um pico em, aproximadamente, $2 \theta=44^{\circ}$ que foi atribuído a fase segregada de rutênio metálico com estrutura hexagonal compacta [102,116,117]. Novamente, não foram observados picos referentes à $\mathrm{RuO}_{2}$ indicando que este material pode estar presente na amostra na fase amorfa $[103,118]$.

Parâmetros como o tamanho médio de cristalito e o grau de liga dos híbridos PtRu/Carbono com diferentes cargas metálicas, após os tratamentos térmicos, são apresentados na TAB. 8. 
TABELA 8 - Tamanho de médio de cristalito e grau de liga para os híbridos $\mathrm{PtRu} /$ Carbono com diferentes composições após tratamento térmico.

\begin{tabular}{ccc}
\hline $\begin{array}{c}\text { Carga metálica } \\
\text { nominal } \\
(\%)\end{array}$ & $\begin{array}{c}\text { Tamanho médio } \\
\text { de cristalito }^{1,2} \\
(\mathbf{n m})\end{array}$ & $\begin{array}{c}\text { Grau de } \\
\text { liga }^{1,3} \\
(\%)\end{array}$ \\
\hline 5 & 8 & 13 \\
10 & 12 & 35 \\
20 & 12 & 66
\end{tabular}

${ }^{1}$ após os tratamentos térmicos, ${ }^{2}$ calculado pela Equação de Scherrer, ${ }^{3}$ calculado pela lei de Vegard.

Os tamanhos médios de cristalito calculados pela equação de Scherrer foram na faixa de 8-12 nm, sendo os maiores valores encontrados para as cargas metálicas mais altas. O grau de liga nas amostras PtRu/Carbono preparadas com diferentes cargas metálicas estão na faixa de 13 a $66 \%$, com valores maiores para as maiores cargas metálicas. Tais resultados estão de acordo com a literatura no que diz respeito ao crescimento de partículas em eletrocatalisadores com alta carga metálica $[123,138]$.

Imagens obtidas por microscopia eletrônica de transmissão dos híbridos PtRu/Carbono com cargas metálicas nominais de 5\% e 20\% são apresentadas na FIG. 22. As imagens obtidas por microscopia eletrônica de transmissão dos híbridos PtRu/Carbono após os tratamentos térmicos mostram que ambos os materiais possuem uma boa dispersão das nanopartículas no suporte de carbono, sendo que o material preparado com uma carga metálica nominal de $5 \%$ em massa apresentou um tamanho médio de partícula igual a $7,7 \mathrm{~nm}$, enquanto o material preparado com uma carga metálica nominal de $20 \%$ em massa apresentou um tamanho médio de partícula de $18,5 \mathrm{~nm}$, indicando que materiais com maiores cargas metálicas apresentam, após os tratamentos térmicos, maiores tamanhos de partícula. 


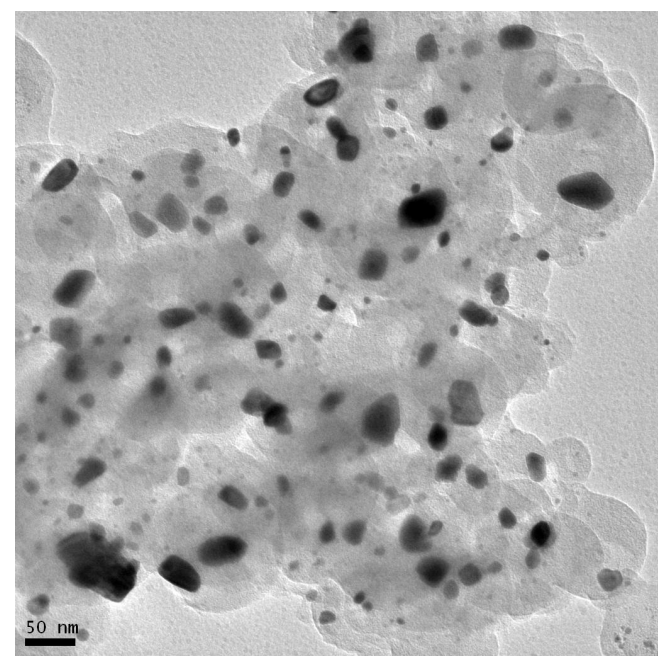

(a)

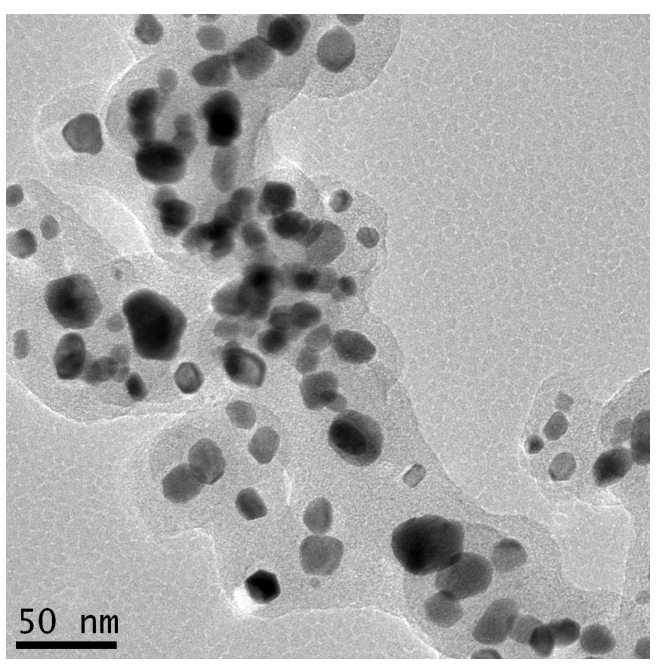

(b)

FIGURA 23 - Micrografias obtidas por microscopia eletrônica de transmissão dos híbridos PtRu/Carbono, tratados termicamente, com carga metálica nominal de (a) $5 \%$ e (b) $20 \%$.

As cronoamperometrias da oxidação de metanol sobre os híbridos PtRu/Carbono com diferentes cargas metálicas preparados por carbonização hidrotérmica e tratados termicamente são apresentados na FIG. 24. A seguinte ordem de atividade eletrocatalítica para a oxidação do metanol foi observada para os híbridos: PtRu/Carbono (5\%) > PtRu/Carbono (10\%) > PtRu/Carbono (20\%). Tal resultado pode ser explicado pelo tamanho de cristalito $[123,124] \mathrm{e}$ pelo teor de rutênio segregado aumentando a probabilidade de ocorrência da espécie $\mathrm{RuO}_{x} \mathrm{H}_{y}[68,128-131]$, conforme discussões anteriores. 


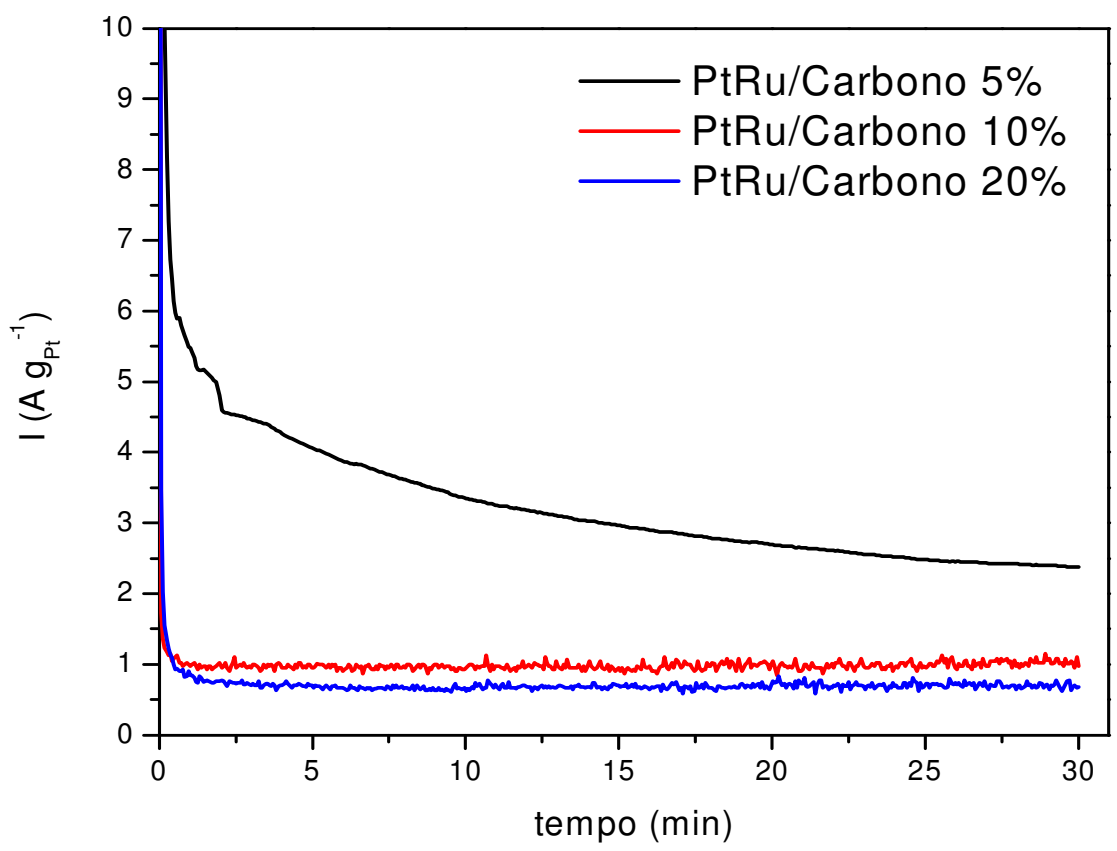

FIGURA 24 - Cronoamperometrias da oxidação do metanol sobre híbridos PtRu/Carbono, preparados com diferentes cargas metálicas, em solução de $0,5 \mathrm{~mol} \mathrm{~L}^{-1}$ de $\mathrm{H}_{2} \mathrm{SO}_{4}$ contendo $1,0 \mathrm{~mol} \mathrm{~L}^{-1}$ de metanol mediante aplicação de $0.5 \mathrm{~V}$ por 30 minutos.

Neste estudo, foram preparados híbridos PtRu/Carbono com diferentes cargas metálicas, sendo que a razão atômica Pt:Ru desses materiais foram similares aos valores nominais. Por outro lado, as cargas metálicas, com exceção do material com $5 \%$ em massa de metais, apresentaram valores discrepantes comparados aos valores nominais. A difração de raios- $X$ desses materiais mostraram picos referentes às fases cfc da platina e hcp do rutênio. Os valores de tamanho médio de cristalito estão na faixa de $8-12 \mathrm{~nm}$ e os valores de grau de liga tiveram valores aumentados com o aumento da carga metálica. As curvas cronoamperométricas de oxidação do metanol sobre os materiais PtRu/Carbono mostraram que o material com maior atividade eletrocatalítica é o PtRu/Carbono (5\%) muito possivelmente devido ao seu menor tamanho de cristalito e menor grau de liga, ou seja, maior teor de rutênio segregado. 


\subsubsection{Estudo do tempo de síntese}

Outro parâmetro de síntese bastante importante, pois influência na morfologia do produto final entre outras propriedades é o tempo de síntese $[31,97]$. Para avaliar esse parâmetro, foram preparados, pelo método da carbonização hidrotérmica, híbridos $\mathrm{PtRu} /$ Carbono com razão atômica $\mathrm{Pt}: \mathrm{Ru}$ de (50:50) e carga metálica nominal de $5 \%$ em massa, utilizando celulose como fonte de carbono e hidróxido de tetrapropilamônio (TPAOH) para o ajuste do $\mathrm{pH}$ do meio reacional com tempos de síntese de 6 e 12 horas. Dados referentes aos híbridos PtRu/Carbono obtidos em diferentes tempos de síntese são apresentados na TAB. 9.

TABELA 9 - Razões atômicas Pt:Ru, rendimentos de carbonização, perdas de massa após tratamentos térmicos e cargas metálicas dos híbridos PtRu/Carbono (50:50) preparados em diferentes tempos de síntese por carbonização hidrotérmica.

\begin{tabular}{ccccc}
\hline $\begin{array}{c}\text { Tempo de } \\
\text { síntese } \\
\text { (h) }\end{array}$ & $\begin{array}{c}\text { Razão } \\
\text { atômica Pt:Ru } \\
\text { EDX }\end{array}$ & $\begin{array}{c}\text { Rendimento de } \\
\text { carbonização } \\
(\%)\end{array}$ & $\begin{array}{c}\text { Perda de } \\
\text { massa } \\
(\%)\end{array}$ & $\begin{array}{c}\text { Carga metálica } \\
\text { TGA } \\
(\%)\end{array}$ \\
\hline 6 & $56: 44$ & 66 & 59 & 6 \\
12 & $58: 42$ & 80 & 59 & 9 \\
\hline
\end{tabular}

Os valores de razão atômica Pt:Ru dos híbridos PtRu/Carbono, preparados em diferentes tempos por carbonização hidrotérmica e tratados termicamente, determinados por EDX foram similares aos valores nominais. As cargas metálicas, determinadas por análise termogravimétrica, dos híbridos PtRu/Carbono preparados por carbonização hidrotérmica, após os tratamentos térmicos, foram iguais a $6 \%$ para o material preparado em 6 horas e $9 \%$ para 0 material preparado em 12 horas, sendo que os possíveis motivos para a discrepância observada no híbrido com maior tempo de síntese já foram discutidos anteriormente. Os valores de rendimento de carbonização foram de $66 \%$ para a síntese em 6 horas e $80 \%$ para o material preparado em 12 horas, indicando, como esperado, que um maior tempo de reação aumenta o rendimento. Os valores de perda de massa, após os tratamentos térmicos, determinados foram de $59 \%$ para ambos os híbridos. 
Micrografias obtidas por microscopia eletrônica de varredura dos materiais PtRu/Carbono tratados termicamente, preparados em diferentes tempos de síntese são apresentadas na FIG. 25.

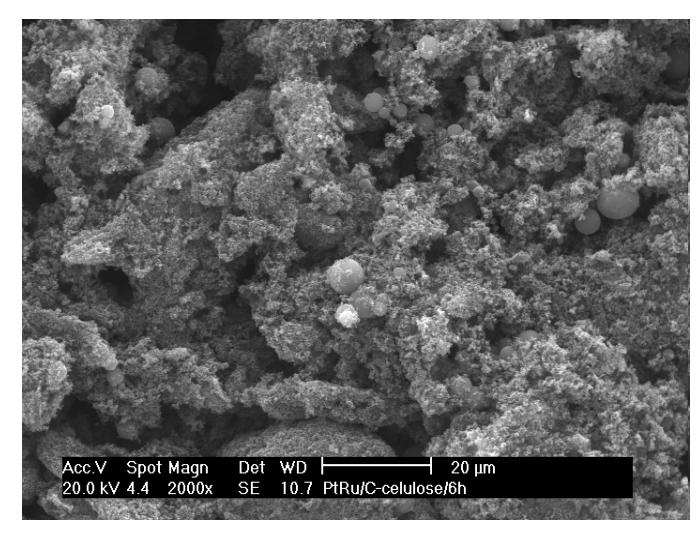

(a)

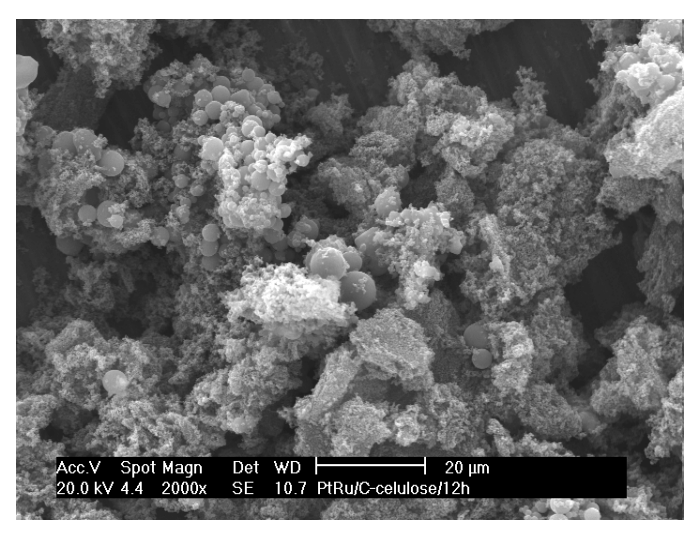

(b)

FIGURA 25 - Micrografias obtidas por microscopia eletrônica de varredura dos híbridos PtRu/Carbono, tratados termicamente, preparados por carbonização hidrotérmica nos tempos de síntese de (a) 6 horas e (b) 12 horas.

As imagens sugerem que, na faixa de tempos estudada, não ocorrem mudanças de morfologia, pois uma visão geral de ambas as amostras indica, aparentemente, morfologias idênticas, isto é, aglomerados irregulares contendo uma estrutura de poros.

Os difratogramas de raios- $X$ dos híbridos PtRu/Carbono tratados termicamente preparados em diferentes tempos de síntese são apresentados na FIG. 26. 


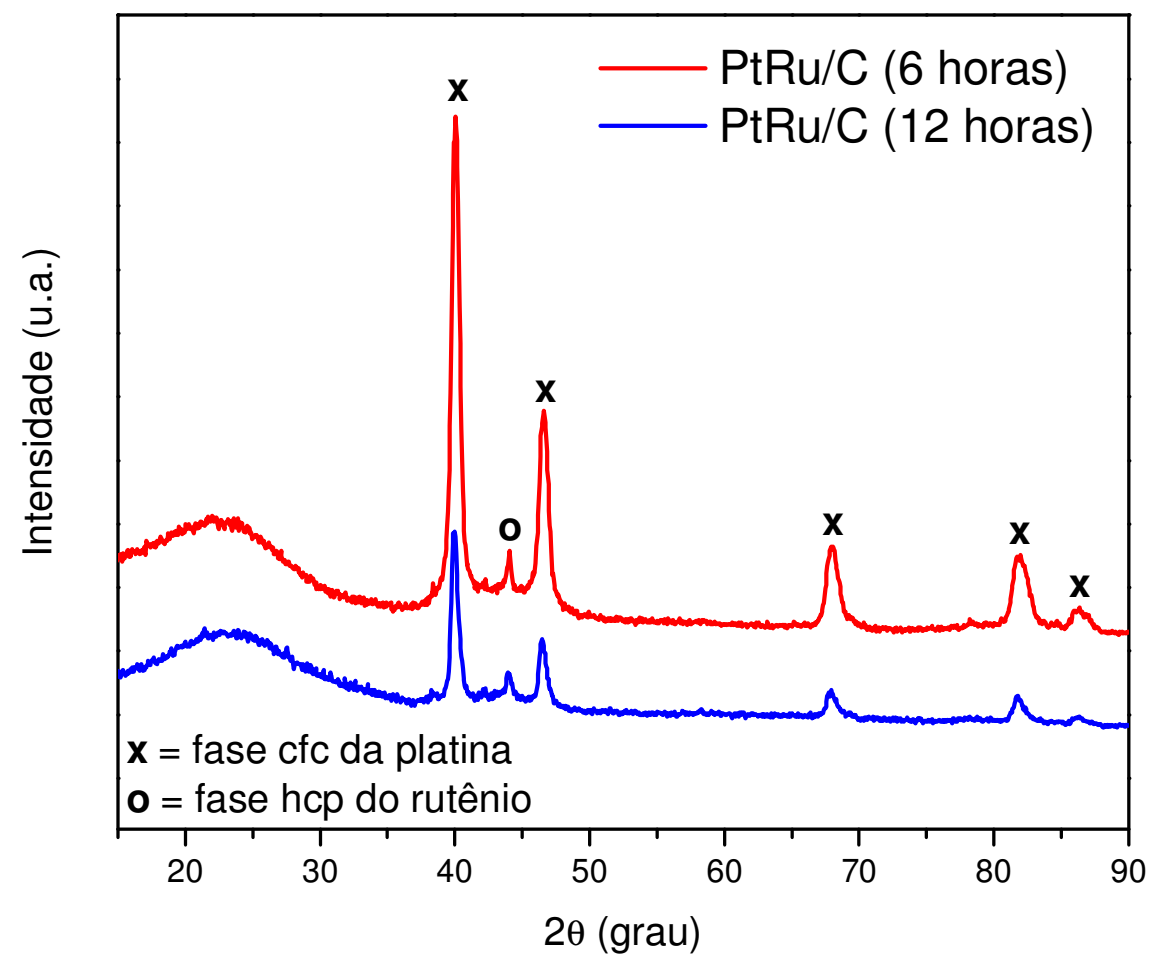

FIGURA 26 - Difratogramas de raios- $X$ dos híbridos PtRu/Carbono preparados pela carbonização hidrotérmica em diferentes tempos de síntese e tratados termicamente.

Os difratogramas dos materiais PtRu/Carbono preparados por carbonização hidrotérmica em diferentes tempos de síntese apresentaram um pico em, aproximadamente, $2 \theta=23^{\circ}$ associado ao material de carbono e cinco picos em, aproximadamente, $2 \theta=40^{\circ}, 47^{\circ}, 67^{\circ}, 82^{\circ}$ e $87^{\circ}$ característicos da estrutura cúbica de face centrada da platina e suas ligas [102,103,115]. Ambas as amostras apresentaram um pico em, aproximadamente, $2 \theta=44^{\circ}$ que foi atribuído a fase segregada de rutênio metálico com estrutura hexagonal compacta [102,116,117]. Como nas outras amostras preparadas por carbonização hidrotérmica, não foram observados picos referentes à $\mathrm{RuO}_{2}$ indicando que este material pode estar presente na amostra na fase amorfa [103,118].

A TAB. 10 apresenta informações provenientes da difração de raios- $X \mathrm{e}$ de isotermas de B.E.T. dos híbridos PtRu/Carbono (50:50) preparados em diferentes tempos de síntese. 
TABELA 10 - Tamanho médio de cristalito, grau de liga, área superficial, volume de mesoporos e volume total de poros dos híbridos PtRu/Carbono (50:50) preparados em diferentes tempos de síntese, após tratamentos térmicos.

\begin{tabular}{cccccc}
\hline $\begin{array}{c}\text { Tempo } \\
\text { de } \\
\text { síntese }\end{array}$ & $\begin{array}{c}\text { Tamanho } \\
\text { de cristalito } \\
(\mathbf{n m})\end{array}$ & $\begin{array}{c}\text { Grau de } \\
\text { liga }\end{array}$ & $\begin{array}{c}\text { Área } \\
\text { superficial } \\
\text { por BET } \\
\left(\mathbf{m}^{2} \mathbf{g}^{-1}\right)\end{array}$ & $\begin{array}{c}\text { Volume de } \\
\text { mesoporos } \\
\left(\mathbf{c m}^{3} \mathbf{g}^{-1}\right)\end{array}$ & $\begin{array}{c}\text { Volume total } \\
\text { de poros } \\
\left(\mathbf{c m}^{3} \mathbf{g}^{-1}\right)\end{array}$ \\
\hline 6 & 8 & 13 & 76 & 0,250 & 0,260 \\
12 & 12 & 21 & 315 & 0,231 & 0,340 \\
\hline
\end{tabular}

Os tamanhos médios de cristalitos dos híbridos PtRu/Carbono calculados pela equação de Scherrer, após os tratamentos térmicos, foram de $8 \mathrm{~nm}$ para 0 material preparado em 6 horas e $12 \mathrm{~nm}$ para o material preparado em 12 horas. Os valores de grau de ligas dos materiais PtRu/Carbono, preparados em diferentes tempos de síntese, foram de $13 \%$ para 6 horas de síntese e $21 \%$ para o material sintetizado em 12 horas. A área superficial e volume de poros, determinado por isotermas de B.E.T., do material preparado em 6 horas foi, respectivamente, de $76 \mathrm{~m}^{2} \mathrm{~g}^{-1}$ e $0,260 \mathrm{~cm}^{3} \mathrm{~g}^{-1}$ e para o material preparado em 12 horas, $315 \mathrm{~m}^{2} \mathrm{~g}^{-1}$ e $0,340 \mathrm{~cm}^{3} \mathrm{~g}^{-1}$. Portanto, a área superficial do material preparado em 12 horas apresentou-se quase 5 vezes maior e o volume total de poros, aproximadamente, 1,5 maior que no material preparado em 6 horas, indicando que um maior tempo de síntese favorece uma maior área superficial. Por outro lado, o aumento no tempo de síntese de 6 para 12 horas resultou em uma pequena diminuição do volume de mesoporos de $0,250 \mathrm{~cm}^{3} \mathrm{~g}^{-1}$ para $0,231 \mathrm{~cm}^{3} \mathrm{~g}^{-1}$.

A FIG. 27 apresenta as cronoamperometrias da oxidação de metanol sobre os híbridos PtRu/Carbono preparados em diferentes tempos de síntese. 


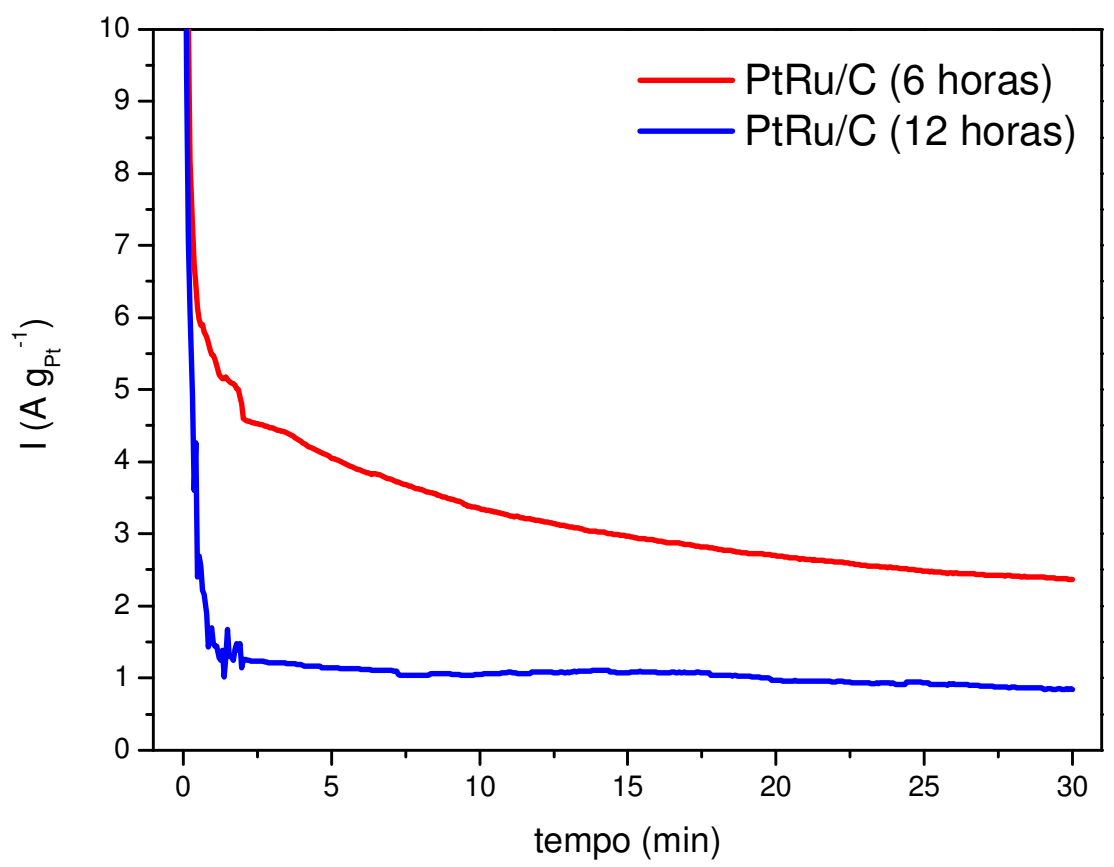

FIGURA 27 - Cronoamperometrias da oxidação do metanol sobre híbridos PtRu/Carbono, preparados por carbonização hidrotérmica em diferentes tempos de síntese, em solução de $0,5 \mathrm{~mol} \mathrm{~L}^{-1}$ de $\mathrm{H}_{2} \mathrm{SO}_{4}$ contendo $1,0 \mathrm{~mol} \mathrm{~L}^{-1}$ de metanol mediante aplicação de $0,5 \mathrm{~V}$ por 30 minutos.

As curvas cronoamperométricas mostraram que o híbrido PtRu/Carbono preparado em 6 horas apresentou uma atividade eletrocatalítica maior que 0 material preparado em 12 horas. As possíveis explicações para este fato residem no menor tamanho de partícula e volume de mesoporos ligeiramente superior do híbrido PtRu/Carbono preparado em 6 horas comparado ao material preparado em 12 horas. Outro fato importante é a espessura da camada de carbono que pode envolver as nanopartículas numa espécie de metal@carbono (metal-core e carbono-shell). Tal espessura aumenta proporcionalmente ao tempo de carbonização $[31,32,97]$ fato este que pode tornar os sítios catalíticos inacessíveis para o metanol. Para melhor verificar o efeito do tempo de síntese, uma faixa mais ampla de tempos deveria ser estudada e os materiais obtidos deveriam ser caracterizados por microscopia eletrônica de transmissão.

Portanto, as razões atômicas $\mathrm{Pt}: \mathrm{Ru}$, determinadas por EDX, dos híbridos $\mathrm{PtRu} / \mathrm{Carbono}$ preparados em 6 e 12 horas apresentaram-se similares aos valores nominais. A carga metálica do híbrido preparado em 6 horas 
apresentou-se razoavelmente próxima do valor nominal, enquanto uma discrepância foi observada na amostra preparada em 12 horas. A difração de raios- $X$ de ambos os materiais apresentaram picos referentes à estrutura cfc da platina e hcp do rutênio, com valores médios de cristalito, calculados pela equação de Scherrer, de $8 \mathrm{~nm}$ para a amostra preparada em 6 horas e $12 \mathrm{~nm}$ para a amostra preparada em 12 horas e o grau de liga, calculado pela lei de Vegard, de ambas as amostras apresentaram valores baixos. O aumento de 6 para 12 horas de síntese resultou em uma pequena diminuição no volume de mesoporos e em um aumento da área superficial e do volume total de poros de, aproximadamente, 5 vezes e 1,5 vezes, respectivamente. A cronoamperometria da oxidação do metanol sobre esses híbridos $\mathrm{PtRu} /$ Carbono indicou uma maior atividade eletrocatalítica para o material preparado em 6 horas que pode ser explicada pelo tamanho de cristalito e volume de mesoporos desse material.

\subsection{OXIDAÇÃO DO METANOL SOBRE ELETROCATALISADORES PtRU/C PREPARADOS UTILIZANDO COMO SUPORTE HÍBRIDOS Ni/CARBONO OBTIDOS PELA CARBONIZAÇÃO HIDROTÉRMICA}

\subsubsection{Influência do teor de brometo de cetiltrimetilamônio na preparação do suporte de carbono (Ni/Carbono) por carbonização hidrotérmica}

$O$ uso do surfactante brometo de cetiltrimetilamônio (CTAB) como template e/ou formador de poros é bastante relatado na literatura com resultados e morfologias obtidas interessantes [91,139-141]. Na síntese de híbridos PtRu/Carbono por carbonização hidrotérmica, a adição de CTAB apresentou uma melhora nas propriedades superficiais desses materiais com uma melhora na "textura" dos mesmos. Entretanto a adição de CTAB no meio reacional apresentou um efeito negativo na atividade catalítica dos híbridos PtRu/Carbono, aparentemente, devido ao bloqueio dos sítios catalíticos dos híbridos [142]. Uma vez que não existem maiores implicações no bloqueio das nanopartículas de níquel, buscando alcançar morfologias e/ou propriedades superficiais interessantes para aplicação dos híbridos Ni/Carbono como suportes de eletrocatalisadores $\mathrm{PtRu} / \mathrm{C}$, resolveu-se estudar a influência da adição de CTAB na produção desses materiais bem como o teor ótimo desse surfactante. 
Os híbridos Ni/Carbono, com carga metálica nominal de 10\% em massa, foram preparado pelo método da carbonização hidrotérmica à $200{ }^{\circ} \mathrm{C}$ usando glicose como fonte de carbono, $\mathrm{NiCl}_{2} \cdot 6 \mathrm{H}_{2} \mathrm{O}$ como fonte de metal e catalisador do processo de carbonização e brometo de cetiltrimetilamônio (CTAB) como formador de poros nas razões molares glicose:CTAB igual a 5 e 10, além de uma amostra controle sem adição de CTAB, conforme procedimento descrito anteriormente. A TAB. 11 apresenta dados de rendimento de carbonização, perda de massa nos tratamentos térmicos, carga metálica e tamanho médio de cristalito de níquel dos híbridos Ni/Carbono preparados com teores de CTAB.

TABELA 11 - Rendimento de carbonização, perda de massa nos tratamentos térmicos, carga metálica e tamanho médio de cristalito de níquel dos híbridos $\mathrm{Ni} /$ Carbono preparados com teores de CTAB.

\begin{tabular}{ccccc}
\hline $\begin{array}{c}\text { Razão molar } \\
\text { glicose:CTAB }\end{array}$ & $\begin{array}{c}\text { Rendimento de } \\
\text { carbonização } \\
(\%)\end{array}$ & $\begin{array}{c}\text { Perda de } \\
\text { massa } \\
(\%)\end{array}$ & $\begin{array}{c}\text { Carga } \\
\text { metálica } \\
(\%)\end{array}$ & $\begin{array}{c}\text { Tamanho } \\
\text { de cristalito } \\
(\mathbf{n m})\end{array}$ \\
\hline sem CTAB & 73 & 53 & 8 & 11 \\
5 & 60 & 54 & 6 & 13 \\
10 & 71 & 54 & 5 & 13 \\
\hline
\end{tabular}

As cargas metálicas determinadas por análise termogravimétrica apresentaram valores menores que o nominal na faixa de 5-8\% em massa. Os valores de rendimento de carbonização foram na faixa de 60 a $73 \%$, com o menor valor registrado para a amostra com razão glicose:CTAB igual a 5 e o maior valor no híbrido preparado sem CTAB. As perdas de massa após os tratamentos térmicos foram na faixa de 53 a $55 \%$. Os tamanhos médios de cristalito, calculados a partir das reflexões (220) da estrutura cúbica de face centrada do níquel, pela equação de Scherrer, foram na faixa de 11-13 nm, com o menor valor para a amostra preparada sem CTAB.

Os difratogramas de raios- $\mathrm{X}$ dos materiais $\mathrm{Ni} / \mathrm{Carbono}$ como-sintetizados e tratados termicamente são apresentados na FIG. 28. 


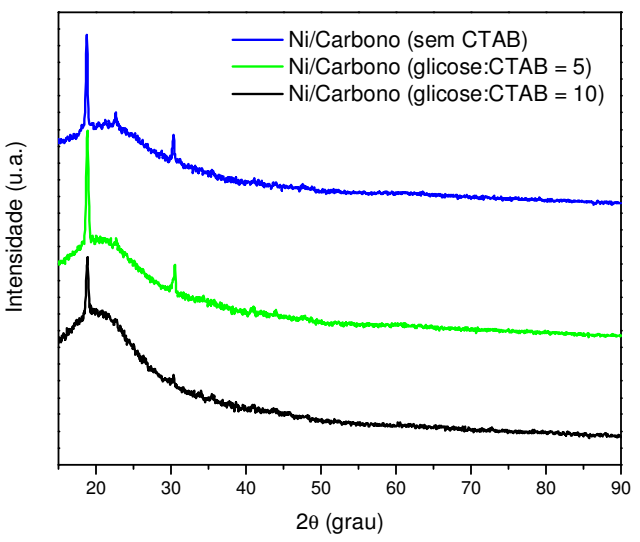

(a)

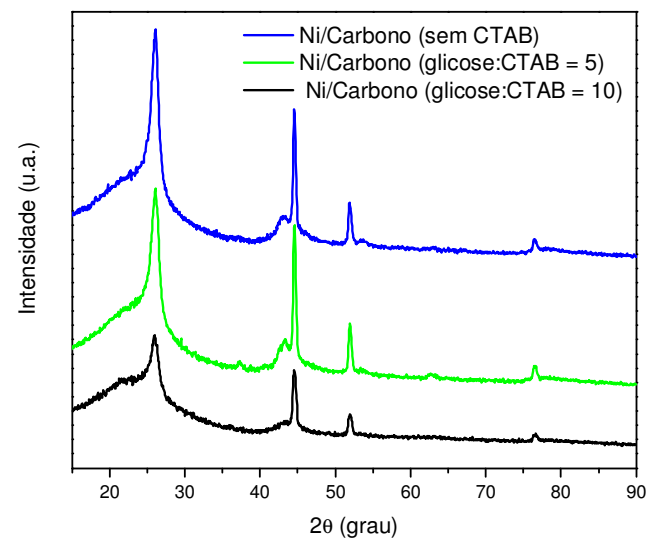

(b)

FIGURA 28 - Difratogramas de raios-X dos híbridos Ni/Carbono (a) como-

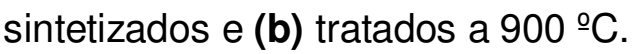

Os materiais como-sintetizados apresentaram um alo em, aproximadamente, $2 \theta=23^{\circ}$ atribuído à fase amorfa de carbono e também outros três picos em, aproximadamente, $2 \theta=18^{\circ}, 30^{\circ}$ e $58^{\circ}$. associados à fase de $\beta$ - $\mathrm{NiOOH}[143,144]$. Após o tratamento térmico em $900 \stackrel{\circ}{\mathrm{C}}$, foram observados três picos em $2 \theta=44^{\circ}, 52^{\circ}$ e $76^{\circ}$ que são atribuídos aos planos (111), (200) e (220) da estrutura cúbica de face centrada (cfc) do níquel [101]. Foram observados também quatro novos picos em, aproximadamente, $2 \theta=26^{\circ}, 43^{\circ}$, $54^{\circ}$ e $78^{\circ}$ associados, respectivamente, às reflexões dos planos (002), (100), (004) e (110) da cadeia grafítica [84,101]. Assim, após o tratamento térmico à $900{ }^{\circ} \mathrm{C}$, os materiais $\mathrm{Ni} /$ Carbono apresentaram nanopartículas de níquel com estrutura cúbica de face centrada dispersas em carbono amorfo com domínios grafíticos.

Segundo Sevilla e Fuertes [101] a formação de nanoestruturas de carbono grafítico é um processo complexo. A princípio, quando materiais carbonáceos impregnados com sais metálicos são aquecidos sob atmosfera inerte, inicialmente o sal decompõe-se formando óxidos metálicos. Nas temperaturas utilizadas durante o tratamento térmico, o carbono reduz os óxidos a elementos metálicos. Finalmente, em temperaturas maiores que $800^{\circ} \mathrm{C}$, as nanopartículas metálicas ou de óxidos contidas dentro da matriz de carbono atuam como catalisadores para a conversão de carbono amorfo em carbono grafítico. A formação de estruturas grafíticas ao redor das 
nanopartículas metálicas ocorre durante a etapa de tratamento térmico por um mecanismo que envolve a dissolução de carbono amorfo nas partículas do catalisador (nanopartículas metálicas) seguida pela precipitação de carbono grafítico.

As imagens obtidas por microscopia eletrônica de transmissão dos materiais Ni/Carbono preparadas sem CTAB e com razão molar glicose:CTAB = 10 são apresentadas na FIG. 29. Ambas as imagens mostram a presença de domínios grafíticos juntamente com uma fase amorfa de carbono, sem maiores diferenças.

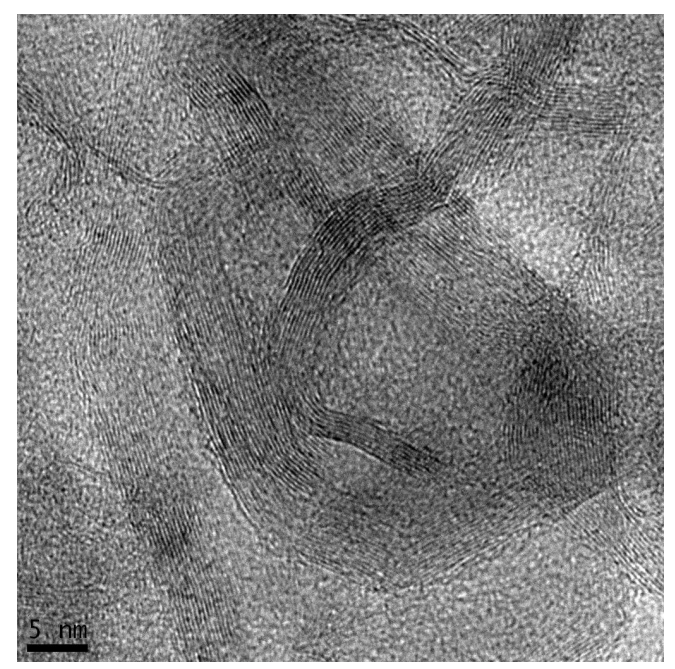

(a)

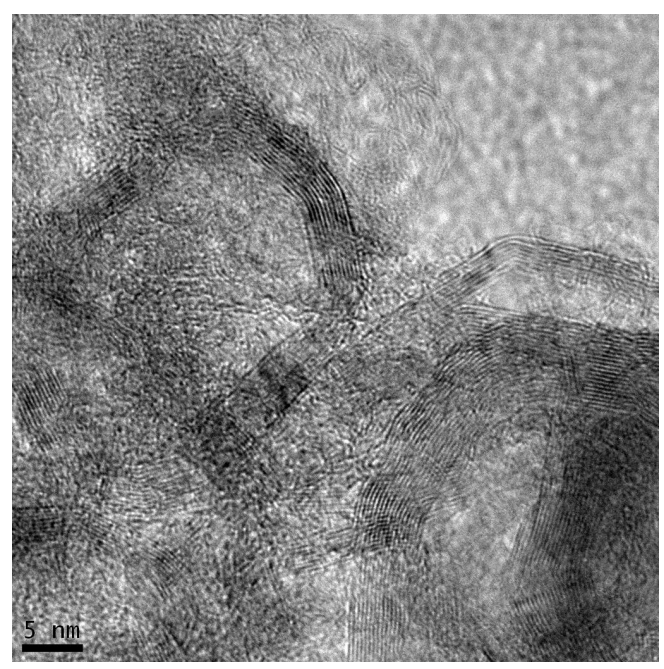

(b)

FIGURA 29 - Imagens obtidas por microscopia eletrônica de transmissão dos híbridos Ni/Carbono, tratados termicamente, preparados: (a) sem CTAB, e (b) com razão molar glicose:CTAB $=10$.

Eletrocatalisadores PtRu/C (50:50) com carga metálica nominal de $20 \%$ em massa foram preparados pelo método da redução por álcool [24,48,67], através da redução sucessiva dos metais platina e rutênio (na primeira etapa foi depositado rutênio e na segunda platina) usando Ni/Carbono como suporte (TAB. 12). Foi adotado o procedimento da redução sucessiva, depositando o rutênio na primeira etapa, devido ao fato de os suportes utilizados terem níquel em sua composição. Em uma co-redução, o níquel é um metal menos nobre que a platina e, portanto, seria deslocado para a solução como conseqüência da redução da platina. Isso causaria um recobrimento dos sítios catalíticos de 
platina uma vez que o rutênio seria reduzido posteriormente, acarretando uma perda de desempenho por parte do catalisador. Tal resultado pode ser observado na cronoamperometria da FIG. 30 pertencente a um estudo anterior em que se utilizou um híbrido Ni/Carbono à base de glicose como suporte para produção de eletrocatalisadores PtRu/C [145].

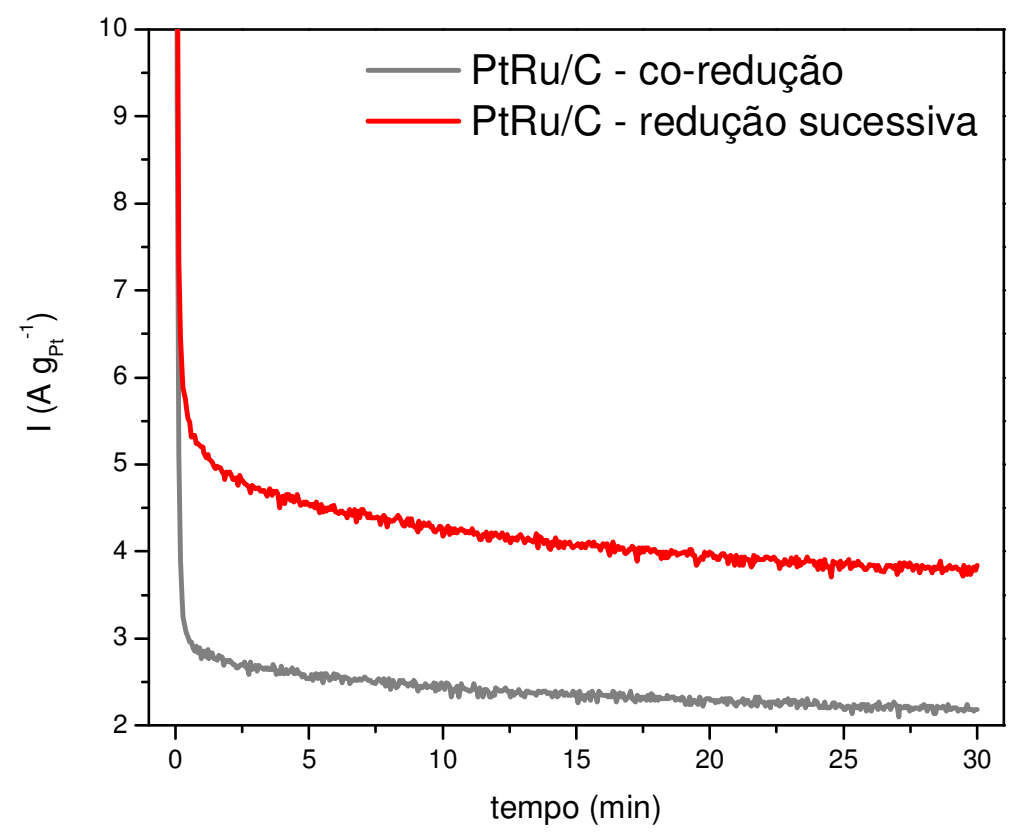

FIGURA 30 - Cronoamperometrias da oxidação do metanol sobre eletrocatalisadores $\mathrm{PtRu} / \mathrm{C}$ preparados por co-redução e redução sucessiva dos íons metálicos pelo método da redução por álcool, utilizando como suporte um híbrido $\mathrm{Ni} /$ Carbono à base de glicose. Esses experimentos foram realizados em meio de $0,5 \mathrm{~mol} \mathrm{~L}^{-1}$ de $\mathrm{H}_{2} \mathrm{SO}_{4}$ contendo $1,0 \mathrm{~mol} \mathrm{~L}^{-1}$ de metanol, mediante aplicação de $0,5 \mathrm{~V}$ durante 30 minutos.

Ao fim de cada etapa de redução pelo método da redução por álcool, o sobrenadante da síntese foi testado utilizando dimetilglioxima [146]. Através deste teste, foi possível observar que, na etapa de redução do rutênio, o níquel do híbrido Ni/Carbono é deslocado para o meio reacional. Entretanto, na etapa de redução da platina, o teste com dimetilglioxima foi negativo para a presença de íons Ni(II) em solução, indicando que não houve dissolução de níquel nesta etapa, muito possivelmente devido ao fato de todo o níquel ter sido deslocado na etapa de redução do rutênio, pois não é detectado níquel nas análises de EDX. 
TABELA 12 - Razão atômica Pt:Ru, carga metálica, tamanho médio de cristalito, área superficial e volume total de poros dos eletrocatalisadores PtRu/C (50:50), com carga metálica nominal de 20\% em massa, preparados pelo método da redução por álcool usando híbridos Ni/Carbono como suporte.

\begin{tabular}{ccccc}
\hline $\begin{array}{c}\text { Razão molar } \\
\text { glicose:CTAB }\end{array}$ & $\begin{array}{c}\text { Razão atômica } \\
\text { Pt:Ru } \\
\text { no suporte }\end{array}$ & $\begin{array}{c}\text { Carga } \\
\text { metálica } \\
(\%)\end{array}$ & $\begin{array}{c}\text { Tamanho médio } \\
\text { de cristalito } \\
(\mathbf{n m})\end{array}$ & $\begin{array}{c}\text { Grau de } \\
\text { liga } \\
(\%)\end{array}$ \\
\hline sem CTAB & $41: 59$ & 13 & 2 & 19 \\
5 & $39: 61$ & 10 & 2 & 35 \\
10 & $37: 63$ & 10 & 3 & 66 \\
\hline
\end{tabular}

Os valores de razão atômica Pt:Ru determinados por EDX são razoavelmente similares aos valores nominais. Todos os eletrocatalisadores apresentaram uma carga metálica igual a, aproximadamente, $50 \%$ do valor nominal. Apesar de a carga metálica ser abaixo do valor nominal, o teste com iodeto de potássio para investigar a presença de íons $\mathrm{Pt}(\mathrm{IV})$ no meio reacional, após a ancoragem dos metais pela redução por álcool, deu negativo para estes íons. Acredita-se que, por algum motivo como, por exemplo, nanopartículas metálicas com carga igual à superfície de carbono [147,148], não foram depositadas sobre o suporte, permanecendo em solução.

Micrografias obtidas por microscopia eletrônica de transmissão e os respectivos histogramas de distribuição de tamanhos de partícula dos eletrocatalisadores $\mathrm{PtRu} / \mathrm{C}$ preparados utilizando como suporte os híbridos $\mathrm{Ni} /$ Carbono preparados sem CTAB e com razão molar glicose:CTAB = 10 são apresentadas na FIG. 31. 
(a)

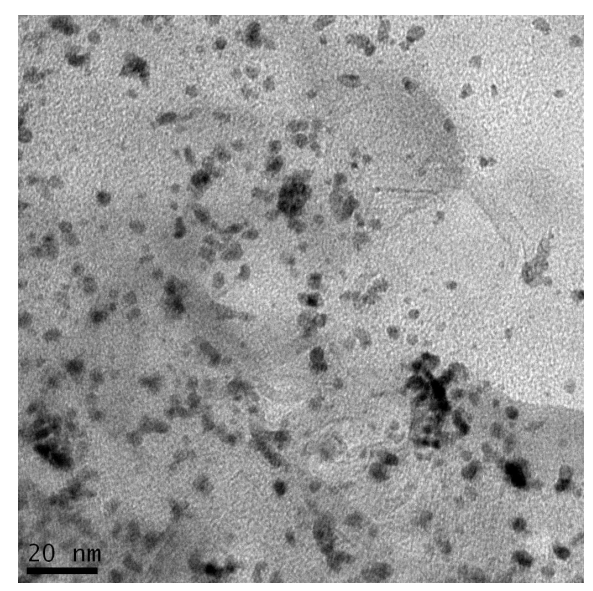

(b)

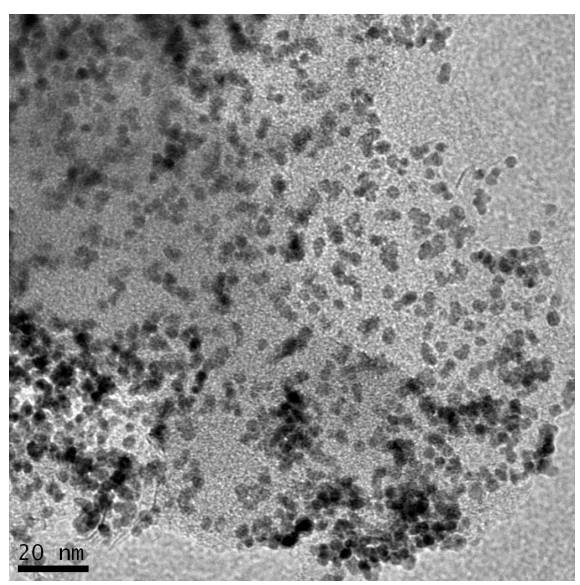

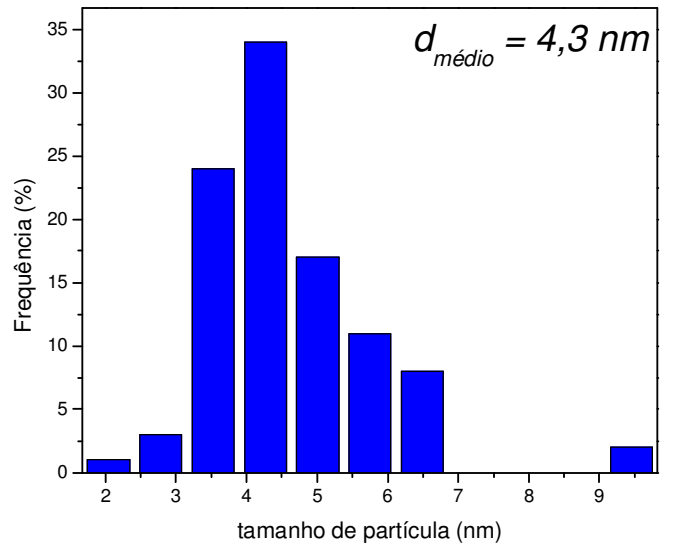

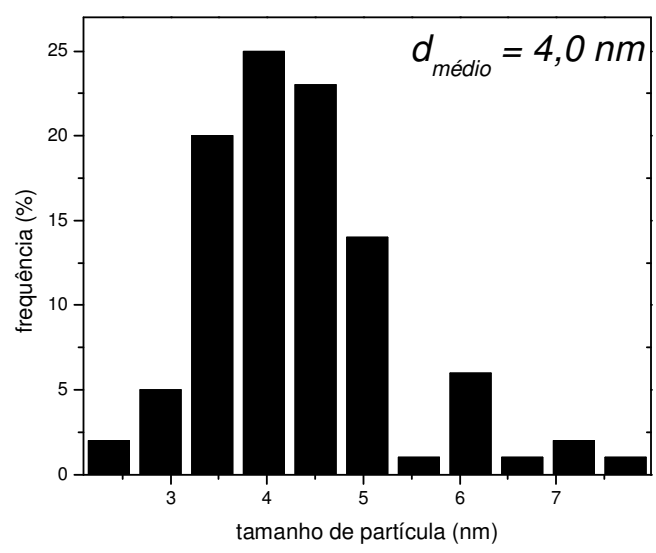

FIGURA 31 - Micrografias obtidas por microscopia eletrônica de transmissão e histogramas com as distribuições dos tamanhos de partícula dos eletrocatalisadores $\mathrm{PtRu} / \mathrm{C}$ preparados utilizando como suporte os híbridos $\mathrm{Ni} /$ Carbono preparados (a) sem CTAB e (b) com razão molar glicose $: C T A B=10$.

As imagens obtidas por microscopia eletrônica de raios- $X$ revelam que os eletrocatalisadores $\mathrm{PtRu} / \mathrm{C}$ preparados pela redução por álcool utilizando os híbridos Ni/Carbono sem CTAB e com razão molar glicose:CTAB = 10 como suporte possuem as nanopartículas metálicas bem dispersas no suporte de carbono com um tamanho médio de partícula igual a $4,3 \mathrm{~nm}$ para 0 eletrocatalisador preparado usando o híbrido Ni/Carbono sem CTAB e 4,0 nm para a amostra preparada com o híbrido Ni/Carbono com razão molar glicose $: C T A B=10$.

Os difratogramas de raios- $\mathrm{X}$ dos eletrocatalisadores $\mathrm{PtRu} / \mathrm{C}$ preparados pelo método da redução por álcool usando os híbridos Ni/Carbono com diferentes teores de CTAB como suporte são apresentados na FIG. 32. 


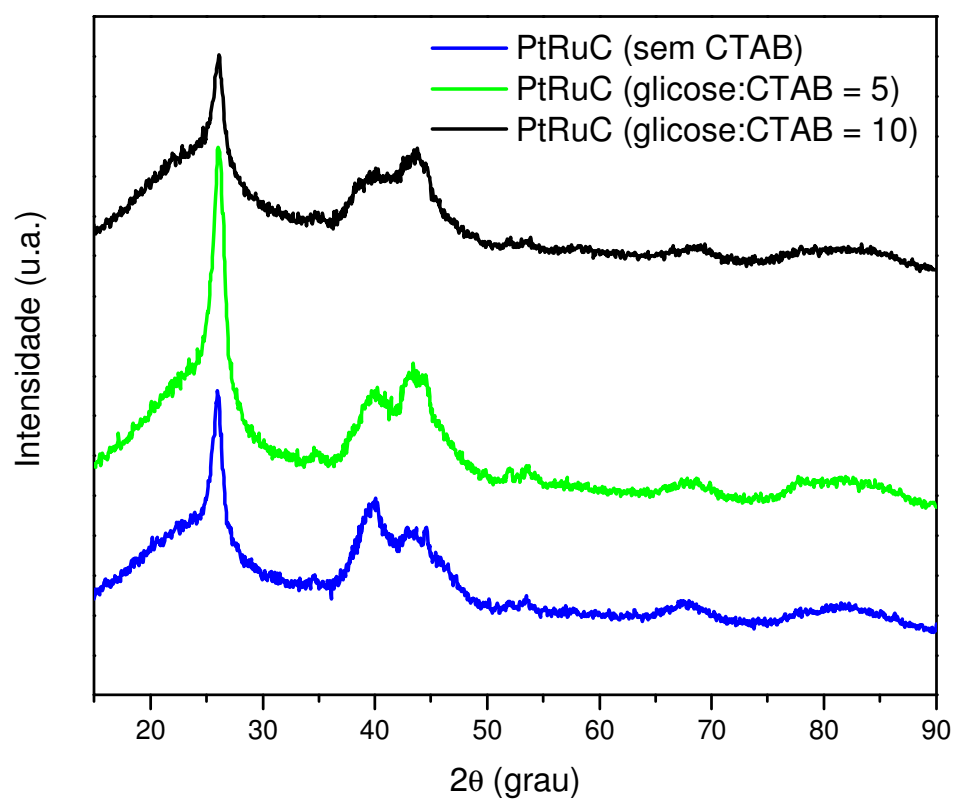

FIGURA 32 - Difratogramas de raios-X dos eletrocatalisadores PtRu/C preparados pelo método da redução por álcool usando híbridos Ni/Carbono com diferentes teores de CTAB como suporte.

As medidas de difração de raios- $X$ para os eletrocatalisadores $P t R u / C$ preparados usando híbridos $\mathrm{Ni} /$ Carbono como suporte apresentaram um pico largo em, aproximadamente, $2 \theta=23^{\circ}$ atribuído a fase amorfa do carbono e quatro picos em, aproximadamente, $2 \theta=26^{\circ}, 43^{\circ}, 54^{\circ}$ e $78^{\circ}$ relativos às fases amorfa e grafítica do carbono [84,101]. Os materiais $\mathrm{PtRu} / \mathrm{C}$ também apresentaram quatro picos em, aproximadamente, $2 \theta=40^{\circ}, 47^{\circ}, 67^{\circ}$ e $82^{\circ}$ que são associados aos planos (111), (200), (220) e (311), respectivamente, da estrutura cúbica de face centrada da platina e suas ligas [102,103,115]. Picos referentes à espécie $\mathrm{RuO}_{2}$ não foram observados indicando que este material pode estar presente na amostra na fase amorfa [103,118]. Os tamanhos médios de cristalito para os eletrocatalisadores $\mathrm{PtRu} / \mathrm{C}$, calculados pela equação de Scherrer, foram na ordem de 2-3 nm. Os graus de liga calculados pela lei de Vegard foram na faixa de $19-66 \%$, aproximadamente, sendo o maior valor encontrado para o eletrocatalisador utilizando como suporte o híbrido com menor teor de CTAB (TAB.12).

A FIG. 33 mostra os voltamogramas cíclicos dos eletrocatalisadores $\mathrm{PtRu} / \mathrm{C}$ em solução $0,5 \mathrm{~mol} \mathrm{~L}^{-1}$ de $\mathrm{H}_{2} \mathrm{SO}_{4}$. 


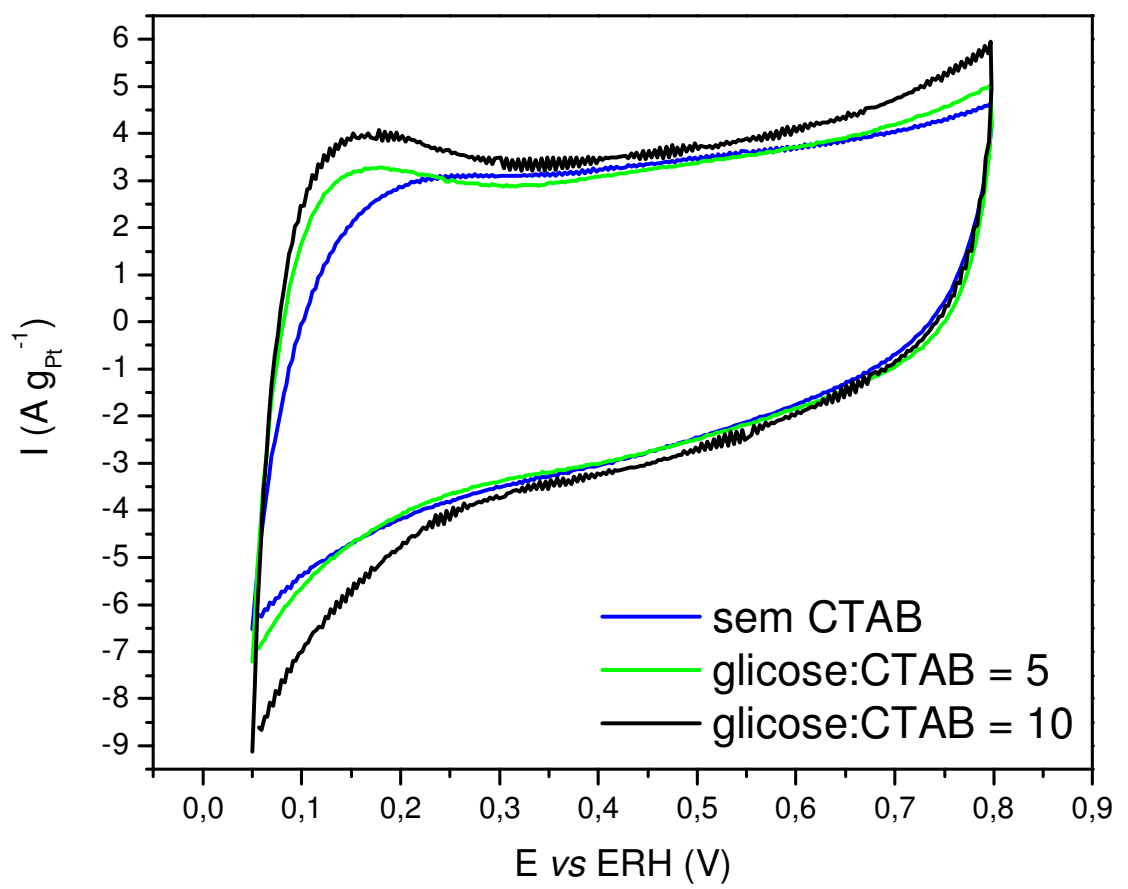

FIGURA 33 - Voltamogramas cíclicos dos eletrocatalisadores PtRu/C, preparados utilizando híbridos $\mathrm{Ni} /$ Carbono com diferentes teores de CTAB como suporte, em solução $0,5 \mathrm{~mol} \mathrm{~L}^{-1}$ de $\mathrm{H}_{2} \mathrm{SO}_{4}$ com uma velocidade de varredura igual a $10 \mathrm{mV} \mathrm{s}^{-1}$.

Todos os eletrocatalisadores PtRu/C apresentaram uma região de adsorçãodesorção de hidrogênio $(0,05-0,4 \mathrm{~V})$ pouco definida conforme característica de materiais PtRu/C 50:50 [24]. Também foi observado um alargamento na região de dupla camada elétrica $(0.4-0.8 \mathrm{~V})$ associada ao comportamento capacitivo dos óxidos de rutênio formados [121,122].

As voltametrias cíclicas para a oxidação eletroquímica do metanol sobre os eletrocatalisadores $\mathrm{PtRu} / \mathrm{C}$, preparados utilizando híbridos Ni/Carbono com diferentes teores de CTAB como suporte, são apresentadas na FIG. 34. 


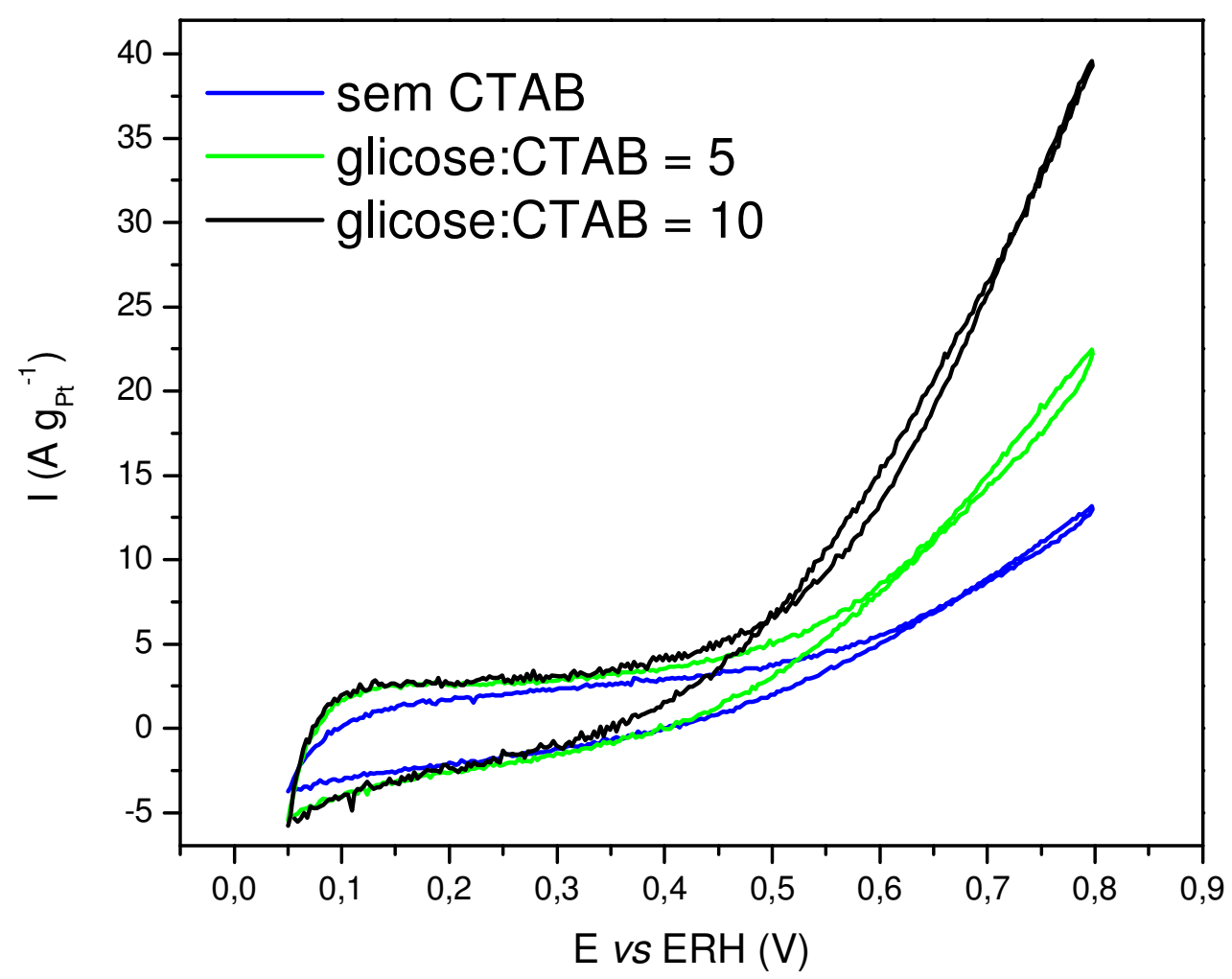

FIGURA 34 - Voltametrias cíclicas para a oxidação eletroquímica do metanol sobre os eletrocatalisadores $\mathrm{PtRu} / \mathrm{C}$, preparados utilizando híbridos $\mathrm{Ni} /$ Carbono com diferentes teores de CTAB como suporte, em solução de $0,5 \mathrm{~mol} \mathrm{~L}^{-1}$ de $\mathrm{H}_{2} \mathrm{SO}_{4}+1,0 \mathrm{~mol} \mathrm{~L}^{-1}$ metanol com velocidade de varredura de $10 \mathrm{mV} \mathrm{s}^{-1}$.

As curvas voltamétricas indicam que a oxidação do metanol inicia-se primeiro no eletrocatalisador PtRu/C (glicose:CTAB $=10$ ), seguido do eletrocatalisador $\mathrm{PtRu} / \mathrm{C}$ (glicose:CTAB = 5) e, por último o eletrocatalisador PtRu/C (sem CTAB). Em potenciais maiores que, aproximadamente, $0,4 \quad \mathrm{~V} \quad$ eletrocatalisador PtRu/C com razão molar glicose:CTAB igual a 10 apresentou os maiores valores de corrente.

A FIG. 35 mostra as cronoamperometrias da oxidação do metanol sobre os eletrocatalisadores $\mathrm{PtRu} / \mathrm{C}$, preparados utilizando híbridos Ni/Carbono com diferentes teores de CTAB como suporte. 


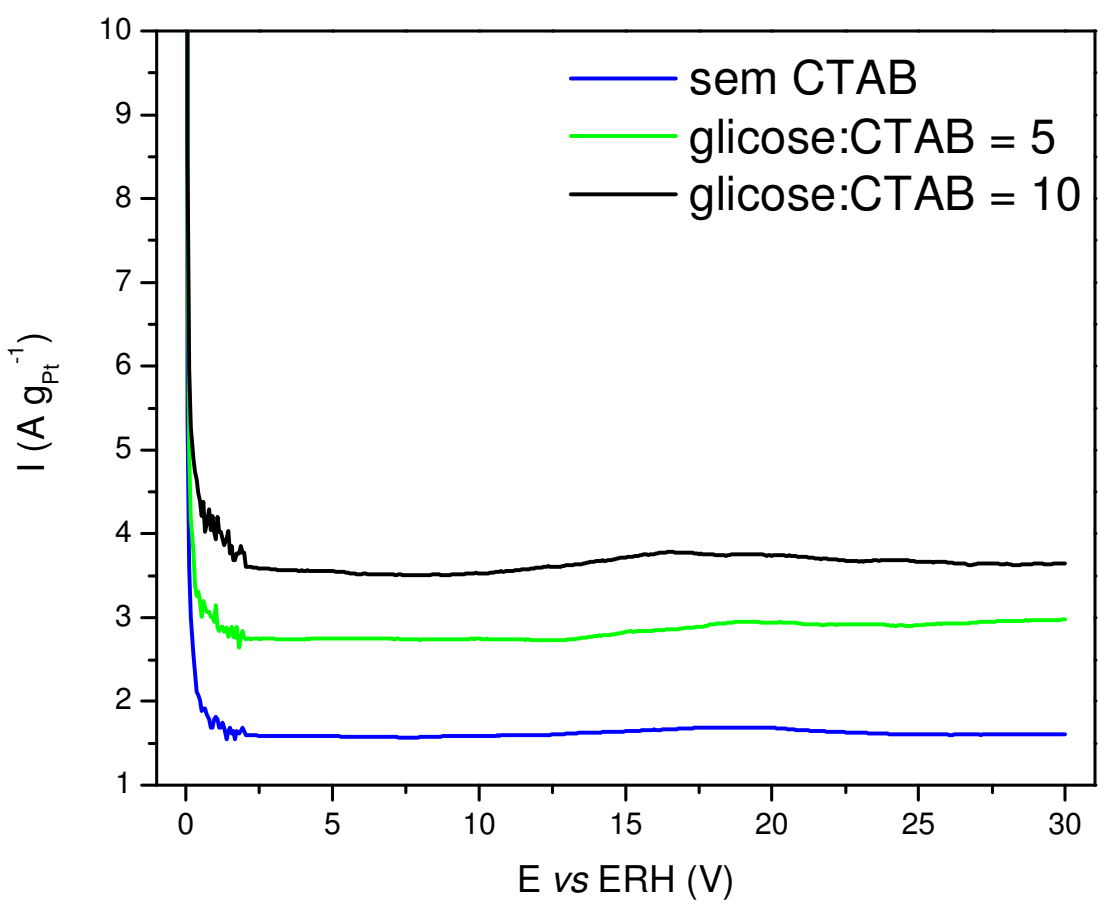

FIGURA 35 - Cronoamperometrias da oxidação do metanol sobre os eletrocatalisadores PtRu/C em solução $0,5 \mathrm{~mol} \mathrm{~L}^{-1}$ de $\mathrm{H}_{2} \mathrm{SO}_{4}$ contendo $1,0 \mathrm{~mol} \mathrm{~L}^{-1}$ metanol mediante aplicação de $0,5 \mathrm{~V}$ durante 30 minutos.

As medidas de cronoamperometria em $0,5 \mathrm{~V}$ durante 30 minutos à temperatura ambiente mostraram a seguinte ordem de atividade eletrocatalítica: PtRu/C (glicose:CTAB = 10) > PtRu/C (glicose:CTAB = 5) > PtRu/C (sem CTAB), indicando que a adição de uma certa quantidade do surfactante catiônico brometo de cetiltrimetilamônio na preparação de híbridos Ni/Carbono apresenta um efeito benéfico. Aparentemente, para estes eletrocatalisadores preparados pelo método da redução por álcool, o maior grau de liga determinou a maior atividade eletrocatalítica para o material preparado usando como suporte o híbrido de razão molar glicose:CTAB igual a 10, concordando com o observado por Aricò [132].

Logo, foram preparados híbridos Ni/Carbono, com diferentes teores de CTAB, por carbonização hidrotérmica. Os difratogramas de raios- $X$ desses híbridos como-sintetizados apresentaram picos referentes a carbono amorfo e fase $\beta-\mathrm{NiOOH}$. Após serem tratadas a $900 \stackrel{\circ}{ } \mathrm{C}$ sob argônio, a fase $\beta-\mathrm{NiOOH}$ deu lugar à fase cfc de níquel metálico e apareceram picos referentes a carbono grafítico juntamente com o pico da fase amorfa do mesmo. As micrografias 
obtidas por microscopia eletrônica de transmissão dos híbridos Ni/Carbono sem $C T A B$ e com razão glicose $: C T A B=10$ evidenciaram a presença de domínios grafíticos em meio à fase amorfa do carbono. Esses híbridos foram utilizados como suporte na preparação de eletrocatalisadores PtRu/C por redução sucessiva de rutênio e platina, respectivamente, pelo método da redução por álcool. Os eletrocatalisadores PtRu/C obtidos apresentaram razões atômicas similares aos valores nominais, entretanto, todos apresentaram cargas metálicas de, aproximadamente, $50 \%$ do valor nominal. A difração de raios- $X$ desses eletrocatalisadores apresentaram picos referentes às fases de carbono amorfo, carbono grafítico e cfc da platina com um tamanho de cristalito da ordem de $2-3 \mathrm{~nm}$ e graus de liga na faixa de $19-66 \%$. A microscopia eletrônica de transmissão dos eletrocatalisadores PtRu/C (sem CTAB) e PtRu/C (glicose:CTAB = 10) mostraram as nanopartículas metálicas bem distribuídas no suporte de carbono com um tamanho médio de partículas de $4,3 \mathrm{~nm}$ e $4,0 \mathrm{~nm}$, respectivamente. O eletrocatalisador PtRu/C (glicose:CTAB $=10$ ) apresentou uma atividade eletrocatalítica, para a oxidação do metanol, superior aos demais materiais, possivelmente devido ao seu maior grau de liga.

\subsubsection{Influência da fonte de carbono na preparação do suporte de carbono (Ni/Carbono) por carbonização hidrotérmica}

Baseado nos estudos de síntese direta de eletrocatalisadores PtRu/C para oxidação eletroquímica de metanol, onde a fonte de carbono possui forte influência na atividade catalítica desses materiais, foi estudada a influência da fonte de carbono na produção de híbridos Ni/Carbono a serem utilizados como suporte para produção de eletrocatalisadores $\mathrm{PtRu} / \mathrm{C}$ pelo método da redução por álcool.

Híbridos Ni/Carbono, com carga metálica de $10 \%$ em massa, foram preparados pelo método da carbonização hidrotérmica à $200^{\circ} \mathrm{C}$ usando glicose, amido e celulose como fonte de carbono, $\mathrm{NiCl}_{2} \cdot 6 \mathrm{H}_{2} \mathrm{O}$ como fonte de metal e catalisador do processo de carbonização e brometo de cetiltrimetilamônio (CTAB) como formador de poros, conforme procedimento descrito anteriormente. $\mathrm{Na}$ etapa anterior, a produção de híbridos Ni/Carbono com razão molar glicose:CTAB superior a 5 não resultaram em "texturas" 
interessantes, principalmente para aplicação do eletrocatalisador nos testes em células unitárias, por isso, neste estudo utilizou-se uma razão molar glicose:CTAB aproximadamente igual a 5. A TAB. 13 apresenta dados referentes aos híbridos $\mathrm{Ni} /$ Carbono preparados com diferentes fontes de carbono.

TABELA 13 - Rendimento de carbonização, perda de massa após os tratamentos térmicos, carga metálica e tamanho médio de cristalito dos híbridos Ni/Carbono preparados com diferentes fontes de carbono.

\begin{tabular}{ccccc}
\hline $\begin{array}{c}\text { Fonte de } \\
\text { carbono }\end{array}$ & $\begin{array}{c}\text { Rendimento de } \\
\text { carbonização } \\
(\%)\end{array}$ & $\begin{array}{c}\text { Perda de } \\
\text { massa } \\
(\%)\end{array}$ & $\begin{array}{c}\text { Carga } \\
\text { metálica } \\
(\%)\end{array}$ & $\begin{array}{c}\text { Tamanho } \\
\text { de cristalito } \\
(\mathbf{n m})\end{array}$ \\
\hline glicose & 67 & 58 & 5 & 12 \\
amido & 52 & 61 & 4 & 12 \\
celulose & 55 & 62 & 6 & $<2$ \\
\hline
\end{tabular}

Os valores das cargas metálicas, determinados por análise termogravimétrica, apresentaram-se menores que o valor nominal, ficando na faixa de $5-6 \%$ em massa. Os valores de rendimento de carbonização registrados estão na faixa de 52 a $67 \%$, e as perdas de massa nos tratamentos térmicos foram na faixa de 58 a $62 \%$. Os tamanhos médios de cristalito, calculados a partir das reflexões (220) da estrutura cúbica de face centrada do níquel, pela equação de Scherrer, foram na faixa de 2-12 nm, com o menor valor registrado para o híbrido preparado com celulose, reiterando que a celulose favorece menores valores de tamanho de partícula.

Os difratogramas de raios- $\mathrm{X}$ dos híbridos Ni/Carbono como-sintetizados e tratados a $900{ }^{\circ} \mathrm{C}$ sob argônio são apresentados na FIG. 36. Os materiais como-sintetizados, preparados com glicose e amido, apresentaram um alo em, aproximadamente, $2 \theta=23^{\circ}$ atribuído à fase amorfa de carbono e também outros três picos em, aproximadamente, $2 \theta=18^{\circ}, 30^{\circ}$ e $58^{\circ}$. associados à fase de $\beta-\mathrm{NiOOH}[142,143]$. O material preparado usando celulose não apresentou picos adicionais indicando a formação de fases amorfas. 


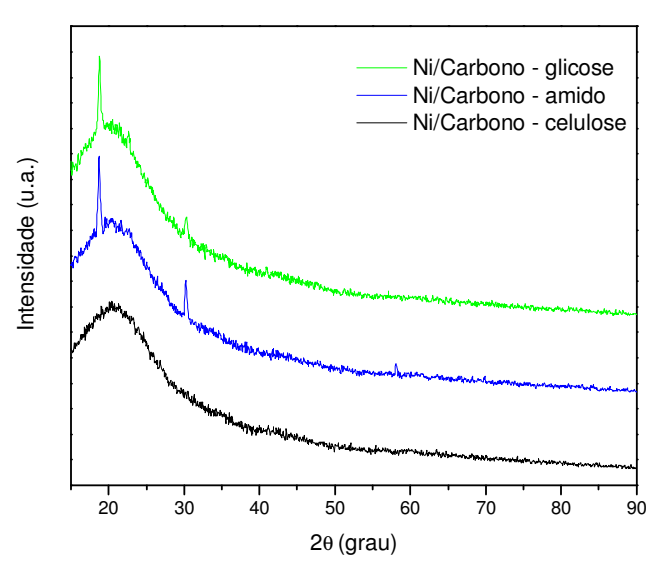

(a)

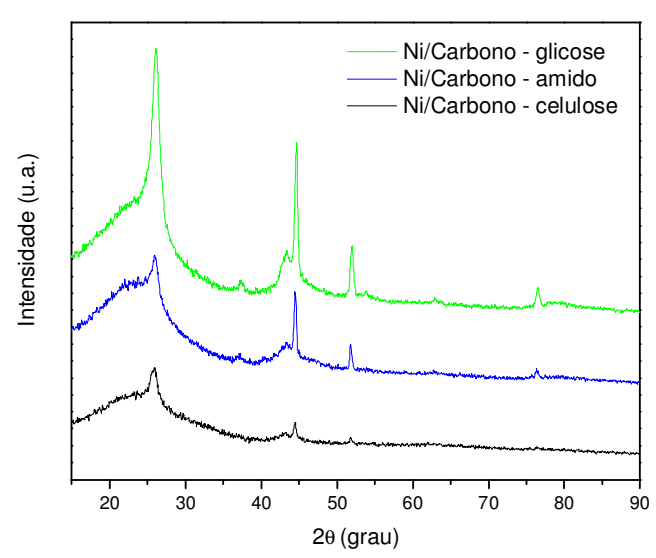

(b)

FIGURA 36 - Difratogramas de raios-X dos híbridos Ni/Carbono preparados com diferentes fontes de carbono (a) como-sintetizados e (b) tratados termicamente.

Após o tratamento térmico a $900^{\circ} \mathrm{C}$ sob argônio, foram observados três picos em $2 \theta=44^{\circ}, 52^{\circ}$ e $76^{\circ}$ que são atribuídos à fase da estrutura cfc do níquel [101] com um tamanho médio de cristalito de $11 \mathrm{~nm}$ (valor calculado usando a equação de Scherrer, a partir do pico referente ao plano (220)). No material $\mathrm{Ni} /$ Carbono preparado usando celulose, o tamanho médio de cristalito é muito pequeno (menor que $2 \mathrm{~nm}$ ) não sendo possível estimar esse valor com base no difratograma. Foram observados, principalmente nos híbridos preparados com glicose e amido, quatro novos picos em, aproximadamente, $2 \theta=26^{\circ}, 43^{\circ}, 5^{\circ} \mathrm{e}$ 78으 associados, respectivamente, às reflexões dos planos (002), (100), (004) e (110) da cadeia grafítica [84,101]. Assim, após o tratamento térmico à $900^{\circ} \mathrm{C}$, os materiais Ni/Carbono apresentaram nanopartículas de níquel com estrutura cúbica de fase centrada dispersas em carbono amorfo com domínios grafíticos, conforme discutido anteriormente. A grafitização promovida pelo tratamento a $900^{\circ} \mathrm{C}$, aparentemente, foi mais acentuada no híbrido $\mathrm{Ni} / \mathrm{C}$ Carbono preparado usando glicose.

A FIG. 37 apresenta imagens obtidas por microscopia eletrônica de transmissão do híbrido Ni/Carbono (preparado com glicose) antes e depois dos tratamentos térmicos. Essas imagens ilustram melhor as mudanças de morfologia decorrentes de cada tratamento térmico. 


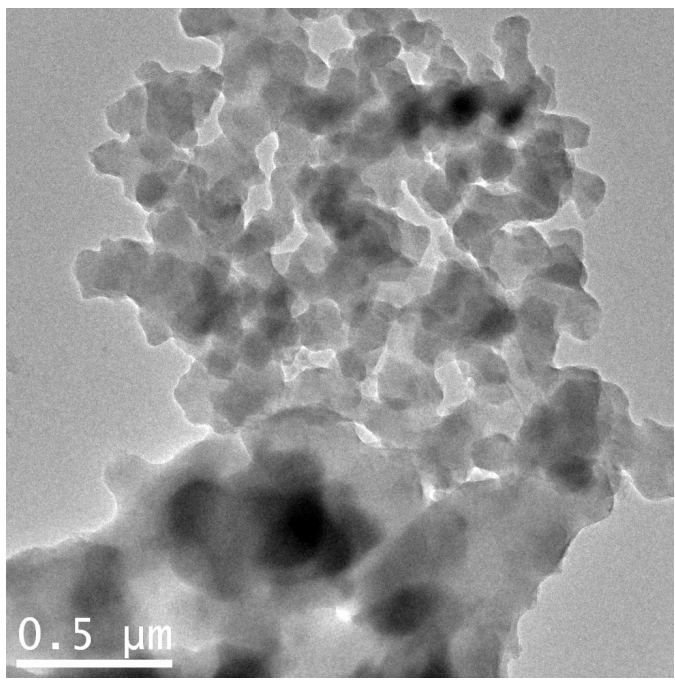

(a)

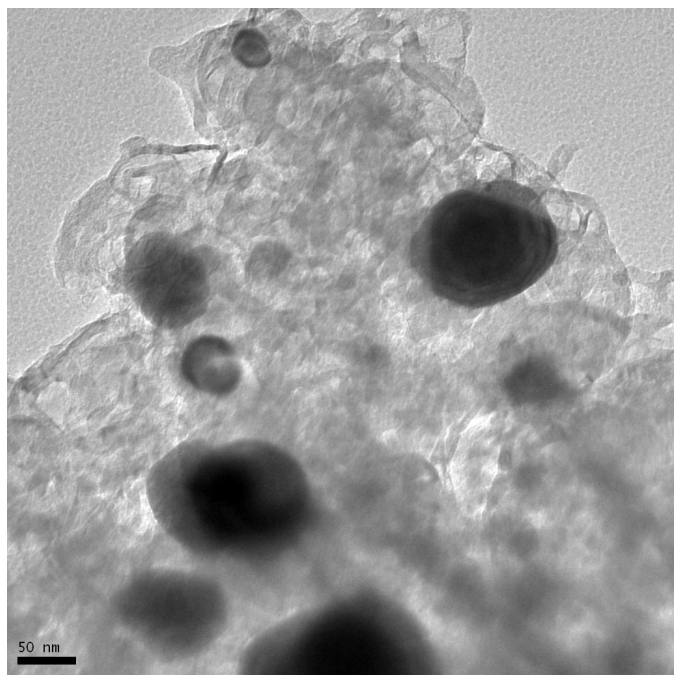

(c)

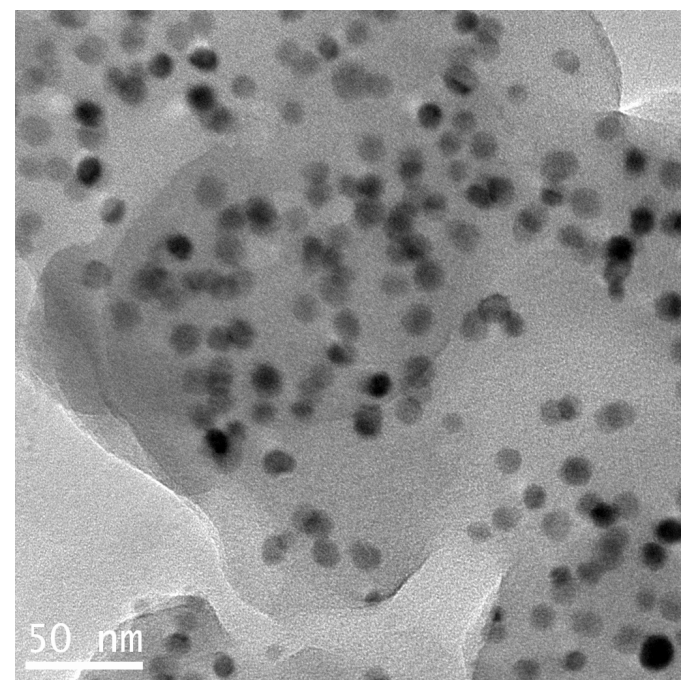

(b)

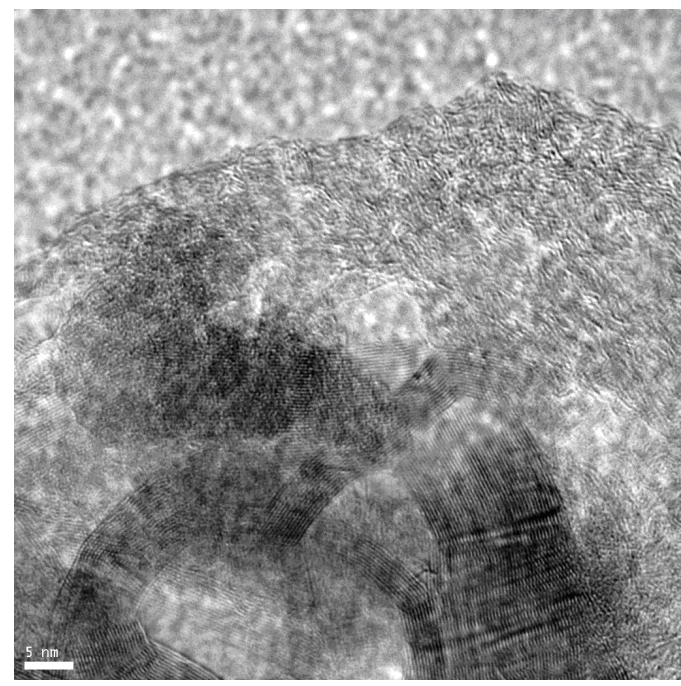

(d)

FIGURA 37 - Imagens obtidas por microscopia eletrônica de transmissão do híbrido Ni/Carbono preparado usando glicose como fonte de carbono (a) como-sintetizado, (b) tratado a $550^{\circ} \mathrm{C}$ sob argônio, (c) tratado a $900^{\circ} \mathrm{C}$ sob argônio e (d) dos domínios grafíticos.

A micrografia do material como sintetizado (FIG. 37a) mostrou um material amorfo. Para o material tratado a $550^{\circ} \mathrm{C}$ (FIG. $37 \mathrm{~b}$ ) aparecem nanopartículas de níquel com um diâmetro de, aproximadamente, $10 \mathrm{~nm}$ homogeneamente distribuídas no carbono amorfo. As micrografias do material tratado a $900^{\circ}$ (FIG. 37c) mostrou um aumento das nanopartículas de níquel na presença de carbono amorfo e grafítico. As camadas de grafeno do carbono grafítico são apresentadas na FIG. 37d. 
A FIG. 38 mostra imagens de microscopia eletrônica de transmissão para os híbridos Ni/Carbono preparados pela carbonização hidrotérmica com glicose e celulose tratados a $900{ }^{\circ} \mathrm{C}$ sob argônio. É possível observar nas imagens a co-existência das fases amorfa em grafítica em ambos os híbridos.

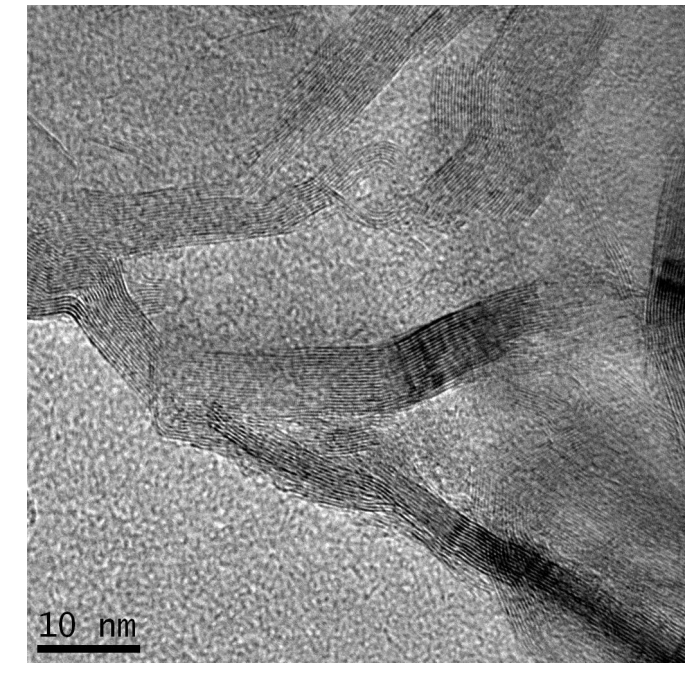

(a)

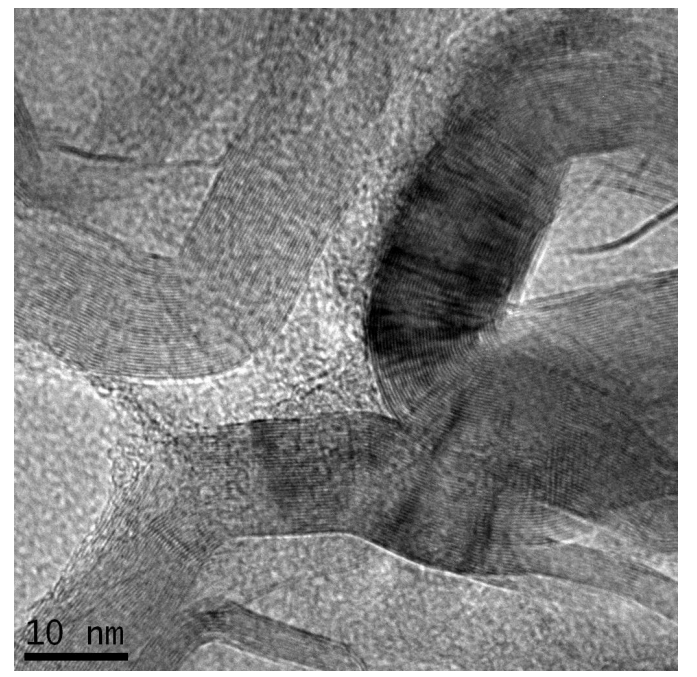

(b)

FIGURA 38 - Imagens de microscopia eletrônica de transmissão, após tratamento a $900 \stackrel{\circ}{ } \mathrm{C}$ sob argônio, dos híbridos Ni/Carbono preparados pela carbonização hidrotérmica usando (a) glicose e (b) celulose.

Espectros de infravermelho dos híbridos $\mathrm{Ni} /$ Carbono preparados com diferentes fontes de carbono por carbonização hidrotérmica e tratados a $900{ }^{\circ} \mathrm{C}$ são apresentados na FIG. 39. Os espectros dos híbridos Ni/Carbono preparados com diferentes fontes de carbono, após os tratamentos térmicos, são bastante semelhantes entre si indicando que esses materiais possuem basicamente os mesmos grupos funcionais em sua superfície, ou seja, esses materiais possuem uma natureza química semelhante. Os espectros apresentaram as seguintes bandas: (i) aproximadamente, em $3400 \mathrm{~cm}^{-1}$ atribuída a vibrações $\mathrm{v}(\mathrm{O}-\mathrm{H})$ em grupos hidroxila, (ii) em $2900 \mathrm{~cm}^{-1}$, banda associada a vibrações $v_{s}(C-H)$ e $v_{a s}(C-H)$ de grupos metila e metileno, (iii) em, aproximadamente, $1570 \mathrm{~cm}^{-1}$ associado a $\mathrm{v}(\mathrm{C}=\mathrm{C})$ de anel aromático [113], (iv) em, aproximadamente, $1380 \mathrm{~cm}^{-1}$ observa-se uma banda associada a deformação angular no plano do grupo metila $\left(\delta_{s}\left(\mathrm{CH}_{3}\right)\right)$ [113], $(\mathrm{v})$ a banda na 
região de, aproximadamente, $1100-1050 \mathrm{~cm}^{-1}$ é atribuída à vibrações $\mathrm{v}(\mathrm{C}-\mathrm{O})$ em álcoois primários.

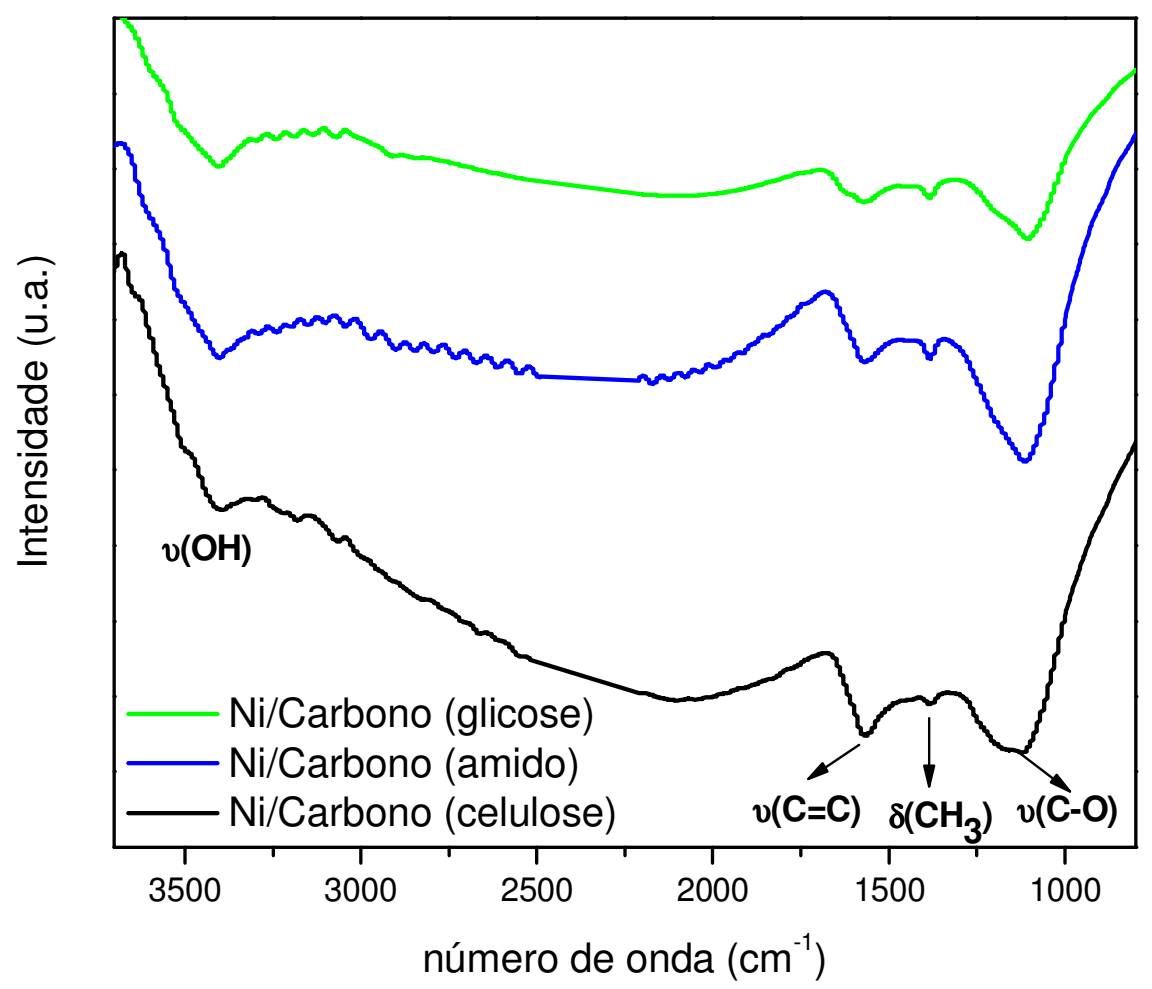

FIGURA 39 - Espectros de infravermelho dos híbridos Ni/Carbono preparados com diferentes fontes de carbono por carbonização hidrotérmica e tratados a $900 \stackrel{\circ}{\circ}$.

Portanto, observa-se a presença de grupos funcionais oxigenados na superfície de todos os híbridos Ni/Carbono, independente da fonte de carbono utilizada.

Assim como no estudo anterior, eletrocatalisadores PtRu/C foram preparados pelo método da redução por álcool $[24,48,67]$, através da redução sucessiva dos metais platina e rutênio (na primeira etapa foi depositado rutênio e na segunda platina) usando Ni/Carbono como suporte (TAB. 14). Os motivos para aplicação da redução sucessiva foram os mesmos citados anteriormente [145]. Para fins comparativos, o suporte associado ao eletrocatalisador $\mathrm{PtRu} / \mathrm{C}$ de maior atividade foi escolhido para a preparação de um eletrocatalisador PtRu/C por co-redução. Os procedimentos adotados neste estudo foram os mesmos descritos no estudo anterior. 
TABELA 14 - Razão atômica Pt:Ru e carga metálica dos eletrocatalisadores PtRu/C (50:50) preparados pelo método da redução por álcool usando como suporte híbridos Ni/Carbono a base de diferentes fontes de carbono.

\begin{tabular}{ccc}
\hline $\begin{array}{c}\text { Fonte de } \\
\text { carbono do } \\
\text { suporte }\end{array}$ & Razão atômica & $\begin{array}{c}\text { Carga } \\
\text { Pt:Ru }\end{array}$ \\
metálica \\
glicose & EDX & $(\%)$ \\
amido & $48: 52$ & 17 \\
celulose & $51: 49$ & 21 \\
\hline
\end{tabular}

Os valores de razão atômica Pt:Ru determinados por EDX são similares aos nominais. Todos os eletrocatalisadores $\mathrm{PtRu} / \mathrm{C}$ preparados usando os híbridos Ni/Carbono, com exceção do preparado com híbrido a base de celulose, apresentaram valores de carga metálica próximos aos valores nominais.

Os difratogramas de raios- $\mathrm{X}$ dos eletrocatalisadores $\mathrm{PtRu} / \mathrm{C}$ preparados pelo método da redução por álcool usando os híbridos Ni/Carbono, preparados com diferentes fontes de carbono, como suporte são apresentados na FIG. 40. As medidas de difração de raios- $X$ para os eletrocatalisadores $P t R u / C$ preparados usando híbridos $\mathrm{Ni} /$ Carbono como suporte apresentaram um pico largo em, aproximadamente, $2 \theta=23^{\circ}$ atribuído a fase amorfa do carbono e quatro picos em, aproximadamente, $2 \theta=26^{\circ}, 43^{\circ}, 54^{\circ}$ e $78^{\circ}$ relativos às fases amorfa e grafítica do carbono [84,101]. 


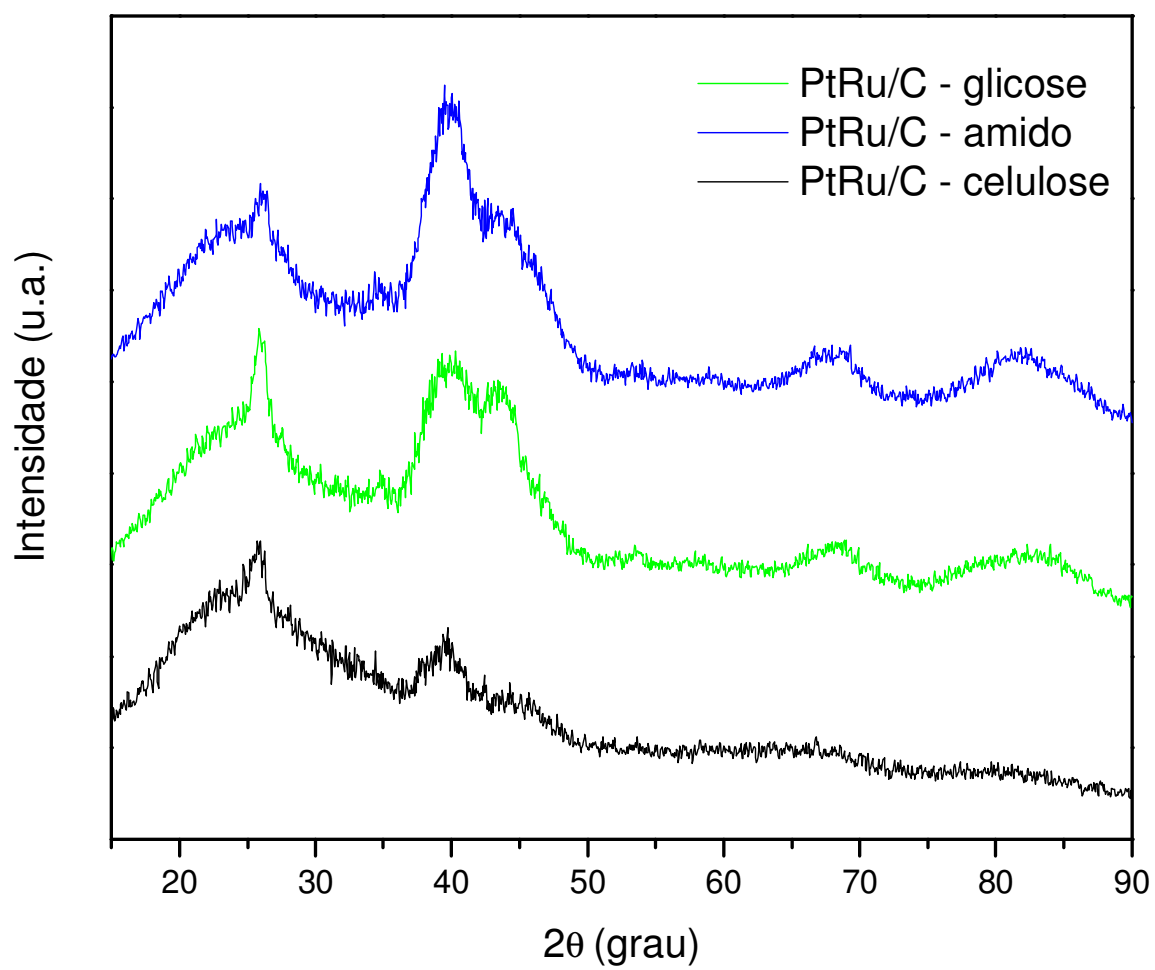

FIGURA 40 - Difratogramas de raios-X dos eletrocatalisadores PtRu/C preparados pelo método da redução por álcool usando como suporte os híbridos Ni/Carbono preparados com diferentes fontes de carbono.

Os materiais PtRu/C também apresentaram quatro picos em, aproximadamente, $2 \theta=40^{\circ}, 47^{\circ}, 67^{\circ}$ e $82^{\circ}$ que são associados aos planos (111), (200), (220) e (311), respectivamente, da estrutura cúbica de face centrada da platina e suas ligas [102,103,115]. Picos referentes à espécie $\mathrm{RuO}_{2}$ não foram observados indicando que, se presente, esta espécie encontra-se na fase amorfa [103,118].

A TAB. 15 apresenta dados obtidos pelos difratogramas de raios- $X$ e por isotermas de B.E.T. dos eletrocatalisadores PtRu/C usando como suporte os híbridos Ni/Carbono preparados por carbonização hidrotérmica com diferentes fontes de carbono. 
TABELA 15 - Tamanho médio de cristalito, grau de liga, área superficial, volume de mesoporos e volume total de poros dos eletrocatalisadores PtRu/C usando como suporte os híbridos Ni/Carbono preparados por carbonização hidrotérmica com diferentes fontes de carbono.

\begin{tabular}{cccccc}
\hline $\begin{array}{c}\text { Fonte de } \\
\text { carbono } \\
\text { do suporte }\end{array}$ & $\begin{array}{c}\text { Tamanho } \\
\text { de cristalito } \\
(\mathbf{n m})\end{array}$ & $\begin{array}{c}\text { Grau } \\
\text { de liga } \\
(\%)\end{array}$ & $\begin{array}{c}\text { Área superficial } \\
\text { por BET } \\
\left(\mathbf{m}^{2} \mathbf{~ g}^{-1}\right)\end{array}$ & $\begin{array}{c}\text { Volume de } \\
\text { mesoporos } \\
\left(\mathbf{c m}^{3} \mathbf{g}^{-1}\right)\end{array}$ & $\begin{array}{c}\text { Volume total } \\
\text { de poros } \\
\left(\mathbf{c m}^{\mathbf{3}} \mathbf{~ g}^{-1}\right)\end{array}$ \\
\hline glicose & 2 & 19 & 42 & 0,0909 & 0,089 \\
amido & 2 & 16 & 53 & 0,1866 & 0,187 \\
celulose & $<2$ & - & 230 & 0,3770 & 0,400 \\
\hline
\end{tabular}

Os tamanhos médios de cristalito, calculados pela equação de Scherrer, foram cerca de $2 \mathrm{~nm}$ para os catalisadores usando híbridos a base de glicose e amido e menor que $2 \mathrm{~nm}$ para o eletrocatalisador PtRu/C preparado utilizando o material a base de celulose. Os graus de liga calculados pela lei de Vegard foram na faixa de, aproximadamente, 16-19\%, não sendo possível o cálculo de um valor confiável desse parâmetro para o eletrocatalisador preparado usando o híbrido Ni/Carbono a base de celulose, pois não foi possível a determinação de um valor de $\theta_{\max }$ para o pico de difração correspondente ao plano (220) da platina. A análise dos dados de área superficial, volume de mesoporos e volume total de poros indica que o aumento da complexidade molecular da fonte de carbono resultou em um aumento dos valores desses parâmetros.

Micrografias obtidas por microscopia eletrônica de transmissão e histogramas com a distribuição de tamanho das nanopartículas para os eletrocatalisadores PtRu/C usando como suportes híbridos Ni/Carbono preparados com diferentes fontes de carbono são apresentados na FIG. 41. As micrografias revelam eletrocatalisadores $P t R u / C$ cujas nanopartículas estão bem dispersas no suporte de carbono. O tamanho médio de partículas foi de 3,5 nm para o material preparado utilizando como suporte o híbrido Ni/Carbono a base de glicose e 3,8 $\mathrm{nm}$ para o eletrocatalisador preparado utilizando como suporte o híbridos Ni/Carbono a base de celulose. 
(a)
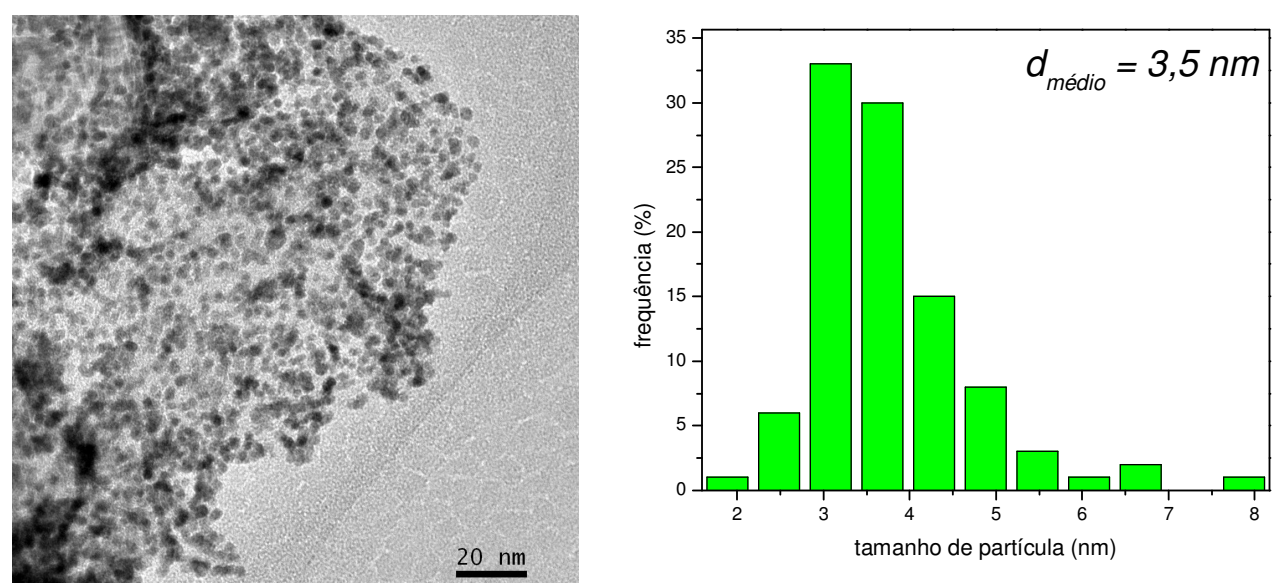

(b)
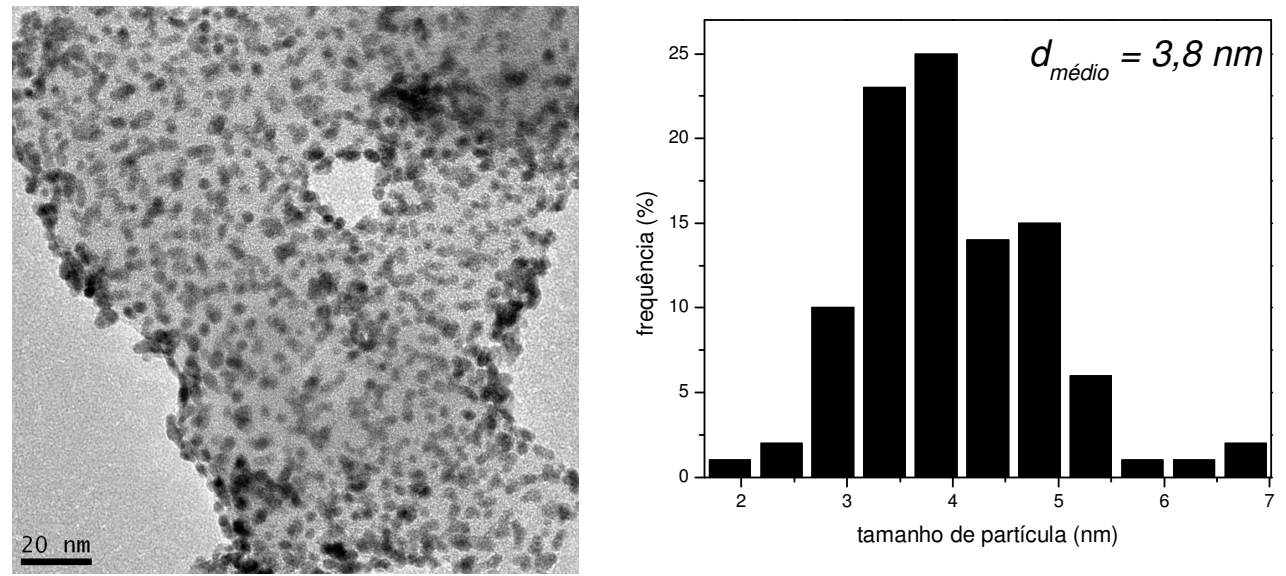

FIGURA 41 - Micrografias obtidas por microscopia eletrônica de transmissão e histogramas com a distribuição de tamanho das nanopartículas para os eletrocatalisadores $\mathrm{PtRu} / \mathrm{C}$ usando como suportes híbridos Ni/Carbono preparados (a) com glicose e (b) com celulose.

A FIG. 42 mostra os voltamogramas cíclicos dos eletrocatalisadores $\mathrm{PtRu} / \mathrm{C}$, usando como suporte os híbridos Ni/Carbono preparados com diferentes fontes de carbono, em solução $0,5 \mathrm{~mol} \mathrm{~L}^{-1}$ de $\mathrm{H}_{2} \mathrm{SO}_{4}$, a temperatura ambiente. 


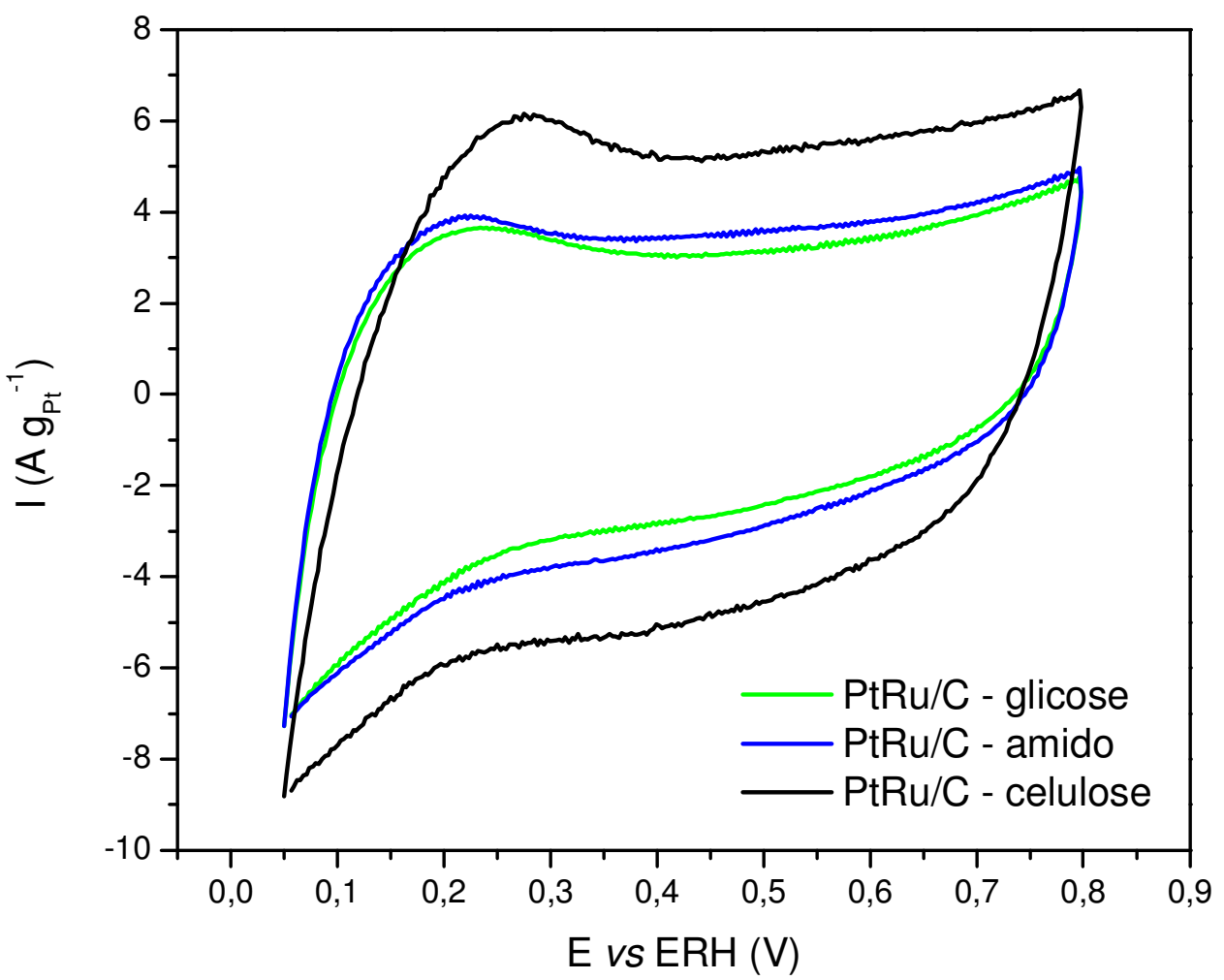

FIGURA 42 - voltamogramas cíclicos dos eletrocatalisadores PtRu/C, usando como suporte os híbridos $\mathrm{Ni} /$ Carbono preparados com diferentes fontes de carbono, em solução $0,5 \mathrm{~mol} \mathrm{~L}^{-1}$ de $\mathrm{H}_{2} \mathrm{SO}_{4}$, a temperatura ambiente e com uma velocidade de varredura igual a $10 \mathrm{mV} \mathrm{s}^{-1}$.

Todos os eletrocatalisadores PtRu/C apresentaram uma região de adsorçãodesorção de hidrogênio $(0,05-0,4 \mathrm{~V})$ pouco definida conforme característica de materiais PtRu/C 50:50 [24]. Também foi observado um alargamento na região de dupla camada elétrica (0.4-0.8V) associada ao comportamento capacitivo dos óxidos de rutênio formados [121,122].

As cronoamperometrias para a oxidação do metanol sobre os eletrocatalisadores $\mathrm{PtRu} / \mathrm{C}$, usando como suporte os híbridos $\mathrm{Ni} /$ Carbono preparados com diferentes fontes de carbono são apresentadas na FIG. 43. 


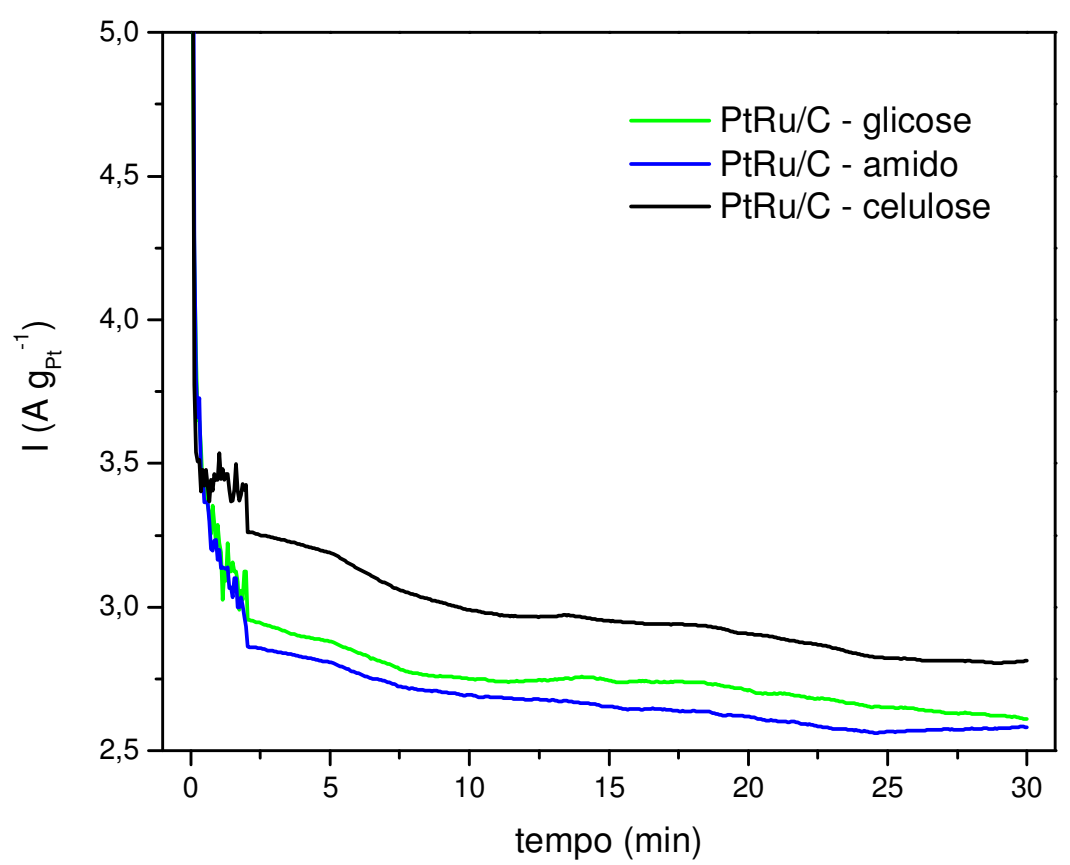

FIGURA 43 - Cronoamperometrias da oxidação do metanol sobre os eletrocatalisadores $\mathrm{PtRu} / \mathrm{C}$, usando como suporte os híbridos $\mathrm{Ni} /$ Carbono preparados com diferentes fontes de carbono, em solução $0,5 \mathrm{~mol} \mathrm{~L}^{-1} \mathrm{de}$ $\mathrm{H}_{2} \mathrm{SO}_{4}$ contendo $1,0 \mathrm{~mol} \mathrm{~L}^{-1}$ de metanol, a temperatura ambiente.

Os eletrocatalisadores $\mathrm{PtRu} / \mathrm{C}$ preparados usando como suporte híbridos $\mathrm{Ni} /$ Carbono à base de diferentes fontes de carbono apresentaram atividades catalíticas para a oxidação do metanol semelhantes. Embora os materiais $\mathrm{Ni} /$ Carbono apresentem diferentes áreas superficiais e volumes de poro, decorrentes do uso de diferentes fontes de carbono, bem como, aparentemente, diferentes graus de grafitização 0 desempenho dos eletrocatalisadores $\mathrm{PtRu} / \mathrm{C}$ preparados com esses híbridos apresentaram desempenhos pouco distintos, com leve superioridade do eletrocatalisador que usa o híbrido Ni/Carbono a base de celulose.

Sabendo-se que o melhor eletrocatalisador foi produzido utilizando como suporte o híbrido Ni/Carbono preparado a partir da celulose, fez-se um teste para avaliar a melhor forma de deposição de platina e rutênio. Como apresentado na FIG. 30 [145], trabalhando com um híbrido Ni/Carbono preparado a base glicose, percebeu-se que a co-deposição de platina rutênio não era o método ideal, pois apresentava uma atividade catalítica inferior ao eletrocatalisador preparado por redução sucessiva. As explicações para esse 
resultado foram especificadas anteriormente no texto, onde se justifica a escolha pelo método de deposição sucessiva de platina e rutênio.

A TAB. 16 apresenta dados dos eletrocatalisadores PtRu/C preparados por co-deposição e por deposição sucessiva pelo método da redução por álcool.

TABELA 16 - Razão atômica Pt:Ru, carga metálica, tamanho médio de cristalito e grau de liga dos eletrocatalisadores PtRu/C preparados por codeposição e por deposição sucessiva pelo método da redução por álcool.

\begin{tabular}{cccc}
\hline $\begin{array}{c}\text { Forma de } \\
\text { redução }\end{array}$ & $\begin{array}{c}\text { Razão atômica } \\
\text { Pt:Ru } \\
\text { (EDX) }\end{array}$ & $\begin{array}{c}\text { Carga } \\
\text { metálica } \\
(\%)\end{array}$ & $\begin{array}{c}\text { Tamanho de } \\
\text { cristalito } \\
(\mathbf{n m})\end{array}$ \\
\hline co-redução & $49: 51$ & 27 & $<2$ \\
sucessiva & $50: 50$ & 26 & $<2$ \\
\hline
\end{tabular}

As razões atômicas $\mathrm{Pt}: \mathrm{Ru}$ dos eletrocatalisadores $\mathrm{PtRu} / \mathrm{C}$, determinadas por EDX, foram similares aos valores nominais. As cargas metálicas apresentaram valores um pouco superiores aos valores nominais. Tais discrepâncias podem estar associadas a perdas decorrentes da dissolução do níquel dos híbridos durante a etapa de deposição dos metais. Os difratogramas de raios- $X$ dos eletrocatalisadores preparados por co-deposição e redução sucessiva apresentaram picos com baixa intensidade e largos, fato este que caracteriza tamanhos de partícula muito pequenos (menores que $2 \mathrm{~nm}$ ) impossibilitando o cálculo desse parâmetro pela equação de Scherrer. Pelos mesmos motivos que não foi possível o cálculo do tamanho médio de cristalito, foi impossível calcular um valor confiável do grau de liga para 0 eletrocatalisador PtRu/C preparado por co-redução.

Os difratogramas de raios- $\mathrm{X}$ dos eletrocatalisadores $\mathrm{PtRu} / \mathrm{C}$ preparados por co-redução e redução sucessiva são mostrados na FIG. 44. 


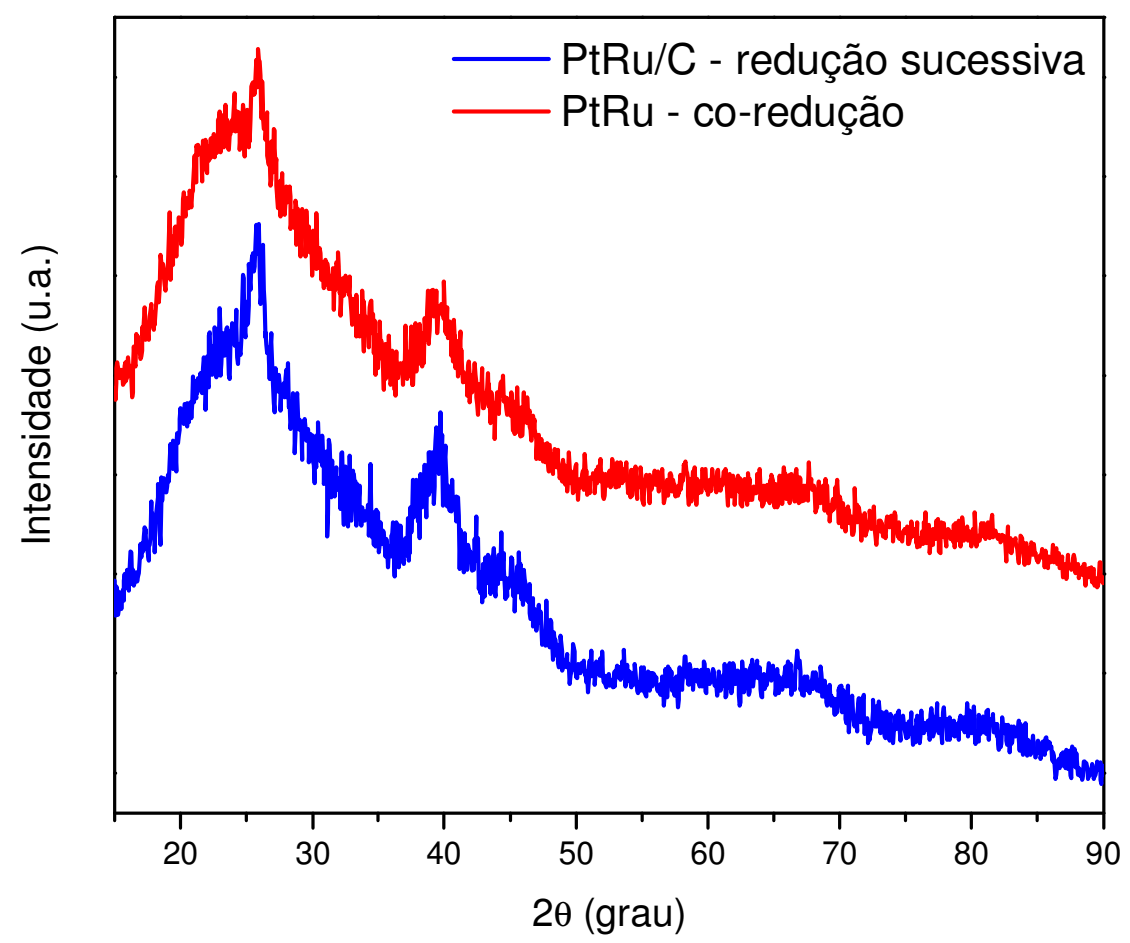

FIGURA 44 - Difratogramas de raios-X dos eletrocatalisadores PtRu/C preparados pelo método da redução por álcool pela co-redução e redução sucessiva dos íons metálicos.

Os difratogramas de raios- $\mathrm{X}$ dos eletrocatalisadores $\mathrm{PtRu} / \mathrm{C}$ preparados por coredução e redução sucessiva, usando híbridos Ni/Carbono como suporte, apresentaram um pico largo em, aproximadamente, $2 \theta=23^{\circ}$ atribuído a fase amorfa do carbono e quatro picos, menos pronunciados, em $2 \theta=26^{\circ}, 43^{\circ}$, $54^{\circ}$ e $78^{\circ}$ relativos às fases amorfa e grafítica do carbono [84,101]. Os picos referentes à fase cfc da platina $2 \theta=40^{\circ}, 47^{\circ}, 67^{\circ}$ e $82^{\circ}$ não ficaram muito definidos, indicando a formação de nanopartículas muito pequenas [102,103,115]. A ausência de picos referentes às fases de rutênio metálico e à espécie $\mathrm{RuO}_{2}$ não foram observados indicando que estas espécies podem estar presentes na fase amorfa [102,103,116-118].

As cronoamperometrias para a oxidação do metanol sobre eletrocatalisadores $\mathrm{PtRu} / \mathrm{C}$ preparados por co-redução e redução sucessiva são apresentados na FIG. 45. 


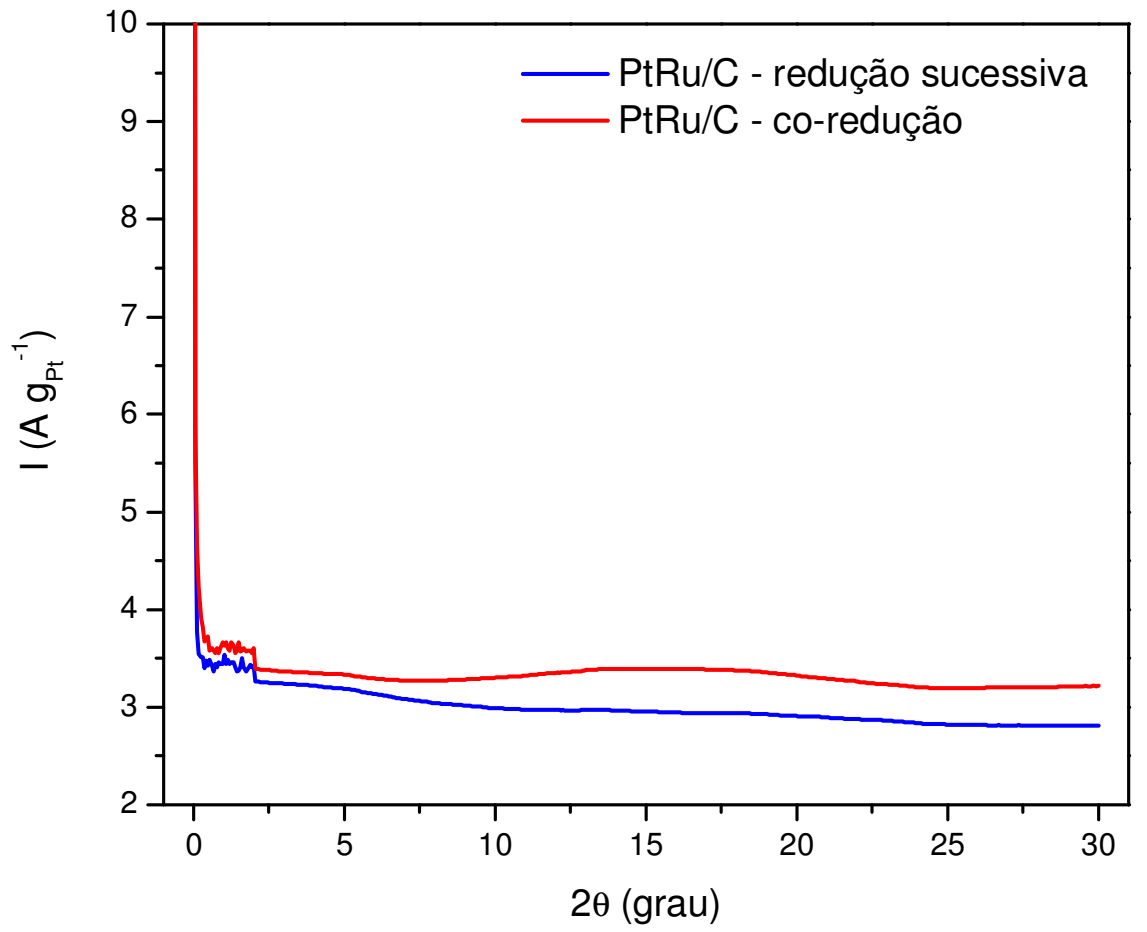

FIGURA 45 - Cronoamperometrias da oxidação do metanol sobre os eletrocatalisadores $\mathrm{PtRu} / \mathrm{C}$, preparados por co-redução e redução sucessiva, usando como suporte o híbrido Ni/Carbono a base de celulose, em 0,5 $\mathrm{mol} \mathrm{L}^{-1}$ de $\mathrm{H}_{2} \mathrm{SO}_{4}$ contendo $1,0 \mathrm{~mol} \mathrm{~L}^{-1}$ de metanol, mediante aplicação de um potencial de $0,5 \mathrm{~V}$ por 30 minutos, a temperatura ambiente.

Observa-se pelas medidas de cronoamperometria que a atividade catalítica dos eletrocatalisadores $\mathrm{PtRu} / \mathrm{C}$ preparados por co-redução e redução sucessiva, usando o híbrido Ni/Carbono a base de celulose como suporte, apresentaram atividades eletrocatalíticas semelhantes. Este dado contradiz o observado quando se utilizou um híbrido $\mathrm{Ni} /$ Carbono à base de glicose como suporte (cronoamperometria da FIG. 30) [145], onde o eletrocatalisador preparado por redução sucessiva apresentou uma maior eletroatividade. Isso pode ser resultado das diferenças morfológicas como área superficial e estrutura de poros (TAB. 15) entre o material preparado com glicose e o preparado com celulose.

Portanto, todas as informações a respeito das características dos híbridos Ni/Carbono preparados pela carbonização hidrotérmica com diferentes fontes de carbono são semelhantes às já mencionadas para os híbridos $\mathrm{Ni} /$ Carbono preparados com diferentes teores de CTAB. Novamente, os 
híbridos foram utilizados como suporte na preparação de eletrocatalisadores $\mathrm{PtRu} / \mathrm{C}$ por redução sucessiva de rutênio e platina, respectivamente, pelo método da redução por álcool. Os eletrocatalisadores PtRu/C obtidos apresentaram razões atômicas e cargas metálicas similares aos valores nominais. A difração de raios- $X$ desses eletrocatalisadores apresentaram picos referentes às fases de carbono amorfo, carbono grafítico e cfc da platina com um tamanho de cristalito da ordem de $2 \mathrm{~nm}$ e graus de liga na faixa de 16 a 19\%. A microscopia eletrônica de transmissão dos eletrocatalisadores PtRu/C mostraram as nanopartículas metálicas bem distribuídas no suporte de carbono com um tamanho médio de partículas de $3,5 \mathrm{~nm}$ para o eletrocatalisador usando como suporte o material Ni/Carbono a base de glicose e 3,8 $\mathrm{nm}$ para 0 material usando o híbrido a base de celulose como suporte. Os eletrocatalisadores usando como suportes híbridos Ni/Carbono a base de diferentes fontes de carbono como suporte apresentaram atividades eletrocatalíticas, para a oxidação do metanol, similares. Quanto ao método de preparação, os eletrocatalisadores $\mathrm{PtRu} / \mathrm{C}$ preparados por co-redução e redução sucessiva, usando o híbrido $\mathrm{Ni} /$ Carbono a base de celulose como suporte, apresentaram atividades eletrocatalíticas semelhantes.

\subsection{TESTES EM CÉLULAS UNITÁRIAS ALIMENTADAS COM METANOL}

Os melhores eletrocatalisadores foram selecionados para serem testados em condições reais de operação, com exceção do eletrocatalisador $\mathrm{PtRu} / \mathrm{C}$ preparado utilizando como suporte o híbrido Ni/Carbono com razão molar glicose:CTAB igual a 10 que não apresentou uma "textura" apropriada para produção da tinta e aplicação no tecido de carbono.

A TAB. 17 apresenta dados dos materiais testados em células unitárias que podem ser relevantes para efeitos de análise e comparação dos desempenhos dos testes em DMFC. Tais dados não serão comentados e/ou discutidos, pois já foram mencionados anteriormente no texto. 
TABELA 17 - Método de síntese, fonte de carbono, suporte, tamanho médio de partículas e carga metálica dos materiais testados em células unitárias alimentadas diretamente com metanol.

\begin{tabular}{ccccc}
\hline $\begin{array}{c}\text { Método de } \\
\text { síntese }\end{array}$ & $\begin{array}{c}\text { Fonte de } \\
\text { carbono }\end{array}$ & Suporte & $\begin{array}{c}\text { Tamanho médio } \\
\text { de partículas } \\
(\mathbf{n m})\end{array}$ & $\begin{array}{c}\text { Carga } \\
\text { metálica } \\
(\%)\end{array}$ \\
\hline carb.hidrot. & celulose & carbono & 7,7 & 6 \\
red.álcool & celulose & Ni/Carbono & 3,8 & 26 \\
red.álcool & - & Vulcan XC72 & 3,5 & 25 \\
\hline
\end{tabular}

A FIG. 47 apresenta os testes em células unitárias dos materiais $\mathrm{PtRu} /$ Carbono preparado pela carbonização hidrotérmica usando celulose como fonte de carbono, PtRu/C (preparado por redução sucessiva) pelo método de redução por álcool usando o híbrido Ni/Carbono a base de celulose como suporte, PtRu/C preparado pela redução sucessiva pelo método da redução por álcool usando Vulcan XC72 como suporte, além do PtRu/C comercial da E-TEK. O valor do potencial de circuito aberto para a célula a combustível contendo o híbrido PtRu/Carbono a base de celulose, preparado por carbonização hidrotérmica, foi de $0,54 \mathrm{~V}$ com uma densidade de potência

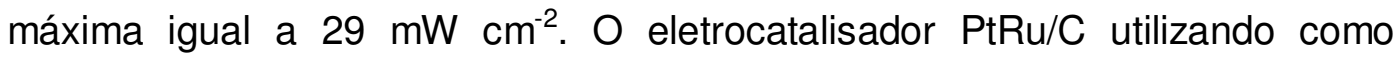
suporte o híbrido Ni/Carbono a base de celulose preparado pelo método da redução por álcool por deposição sucessiva apresentou um potencial de circuito aberto de $0,68 \mathrm{~V}$ e densidade de corrente máxima de $42 \mathrm{~mW} \mathrm{~cm}$, enquanto o eletrocatalisador similar preparado utilizando Vulcan XC72 como suporte apresentou, respectivamente, $0,71 \mathrm{~V}$ e $32 \mathrm{~mW} \mathrm{~cm}^{-2}$. O eletrocatalisador comercial PtRu/C da E-TEK apresentou valores de potencial de circuito aberto e densidade máxima de corrente iguais $0,76 \mathrm{~V}$ e $70 \mathrm{~mW} \mathrm{~cm}$. 


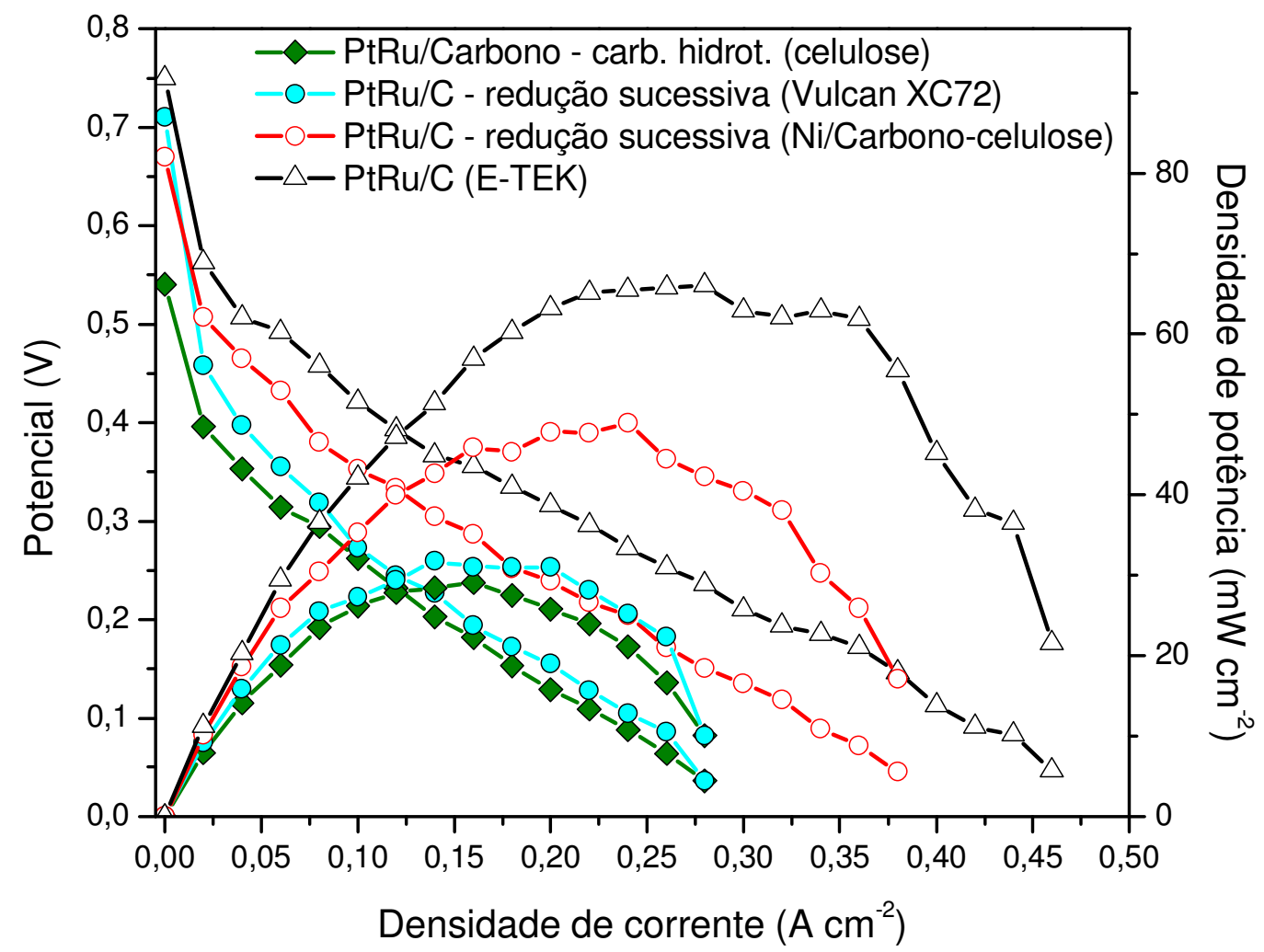

FIGURA 46 - Desempenhos eletroquímicos de uma DMFC $5 \mathrm{~cm}^{2}$ em $100^{\circ} \mathrm{C}$ usando eletrocatalisadores anódicos $\mathrm{PtRu} / \mathrm{C}$ preparados por diferentes métodos (com cargas de $0,5 \mathrm{mg}_{\mathrm{Pt}} \mathrm{cm}^{-2}$ no ànodo e $1,0 \mathrm{mg}_{\mathrm{Pt}} \mathrm{cm}^{-2}$ no cátodo), utilizando membrana Naifion 117, solução $2 \mathrm{~mol} \mathrm{~L}^{-1}$ metanol com fluxo de $2 \mathrm{~mL} \mathrm{~min}^{-1}$, pressão de oxigênio igual a 2 bar e temperatura da célula igual a $100 \stackrel{\circ}{ } \mathrm{C}$.

O principal dado a ser destacado nos testes em células unitárias alimentadas diretamente com metanol é o desempenho do eletrocatalisador $\mathrm{PtRu} / \mathrm{C}$ preparado a partir da redução sucessiva dos íons metálicos pelo método da redução por álcool utilizando como suporte o híbrido Ni/Carbono a base de celulose que mostrou-se superior ao desempenho do eletrocatalisador similar PtRu/C preparado utilizando carbono Vulcan XC72 como suporte. Tal resultado pode ser explicado pela presença dos domínios grafíticos e pela estrutura de poros do híbrido Ni/Carbono utilizado como suporte. 


\section{CONCLUSÕES}

A carbonização hidrotérmica mostrou-se um método capaz de produzir híbridos PtRu/Carbono ativos para a oxidação eletroquímica do metanol. Todos os parâmetros estudados ( $\mathrm{pH}$ e adição de surfactante, razão atômica Pt:Ru, diferentes fontes de carbono, carga metálica e tempo de síntese) apresentaram influência na atividade catalítica dos híbridos PtRu/Carbono obtidos. As eletroatividades desses híbridos, aparentemente, são função, principalmente, do tamanho de partículas, grau de liga e teor de rutênio segregado e estrutura de poros que, por sua vez, são propriedades dependentes dos parâmetros estudados. O material PtRu/Carbono preparado a base de celulose, usando hidróxido de tetrapropilamônio (TPAOH) no ajuste do pH do meio reacional, com razão atômica Pt:Ru igual a 50:50, carga metálica nominal de 5\% em massa e tempo de síntese de 6 horas o que apresentou a melhor atividade eletrocatalítica para a oxidação do metanol.

A produção de híbridos Ni/Carbono pela carbonização hidrotérmica para uso como suportes de eletrocatalisadores $\mathrm{PtRu} / \mathrm{C}$ preparados pelo método da redução por álcool mostrou-se bastante promissora. Estudos aqui apresentados indicam que a adição de brometo de cetiltrimetilamônio (CTAB) em certas quantidades resulta em uma melhora na atividade catalítica dos eletrocatalisadores. Ao contrário do estudo envolvendo a produção de híbridos $\mathrm{PtRu} /$ Carbono, o aumento da complexidade molecular da fonte de carbono na produção de híbridos Ni/Carbono por carbonização hidrotérmica não resultou em incrementos significativos da atividade eletrocatalítica. Os eletrocatalisadores PtRu/C usando como suporte híbridos Ni/Carbono a base de diferentes fontes de carbono preparados a partir da redução sucessiva dos íons metálicos pelo método da redução por álcool apresentaram, na cronoamperometria, valores de corrente similares após 30 minutos de experimento.

Nos testes em células unitárias alimentadas diretamente com metanol, o eletrocatalisador $\mathrm{PtRu} / \mathrm{C}$ preparado a partir da redução sucessiva dos íons metálicos pelo método da redução por álcool utilizando como suporte o híbrido $\mathrm{Ni} /$ Carbono a base de celulose apresentou um desempenho superior 
comparado ao eletrocatalisador $\mathrm{PtRu} / \mathrm{C}$ similar preparado utilizando carbono Vulcan XC72 como suporte, possivelmente, devido aos domínios grafíticos do carbono e à estrutura de poros do híbrido Ni/Carbono utilizado como suporte. 


\section{TRABALHOS FUTUROS}

Estudar fontes de carbono alternativas como, por exemplo, resíduos vegetais (folhas, cascas de frutos, sementes) para aplicação como suportes de eletrocatalisadores.

Realizar uma caracterização superficial por espectroscopia fotoeletrônica de raios-X (XPS) a fim de comparar a composição e vizinhanças químicas dos híbridos metal/carbono preparados pela carbonização hidrotérmica com eletrocatalisadores PtRu/C preparados por outros métodos.

Testar outros solventes durante o processo de carbonização como etanol, etilenoglicol, dietilenogicol, entre outros, transformando o método hidrotermal em um método solvotermal.

Adaptar a metodologia desenvolvida nesse trabalho para a preparação de híbridos metal/carbono com outras composições como, por exemplo, $\mathrm{PtSn} /$ Carbono, PtRuCe/Carbono, entre outras, para aplicação como ânodos na oxidação eletroquímica de metanol e etanol.

Testar outros surfactantes na síntese dos híbridos PtRu/Carbono e $\mathrm{Ni} /$ Carbono, investigando a influência da estrutura e cadeia do surfactante na morfologia e atividade dos híbridos obtidos.

Investigar a influência da concentração de fonte de carbono (glicose, amido e celulose) bem como, no caso dos híbridos Ni/Carbono, a influência do teor de níquel na morfologia e propriedades dos híbridos obtidos. 


\section{TRABALHOS PUBLICADOS}

\subsection{TRABALHOS PUBLICADOS EM ANAIS DE EVENTOS}

[1] M.M. Tusi, O.V. Correa, A.O. Neto, M. Linardi, E.V. Spinacé, Preparation of PtRu/Carbon hybrid structures by hydrothermal carbonization for methanol electro-oxidation, $5^{\text {th }}$ Brazilian MRS Meeting 2006, Florianópolis - Brasil, 2006.

[2] M.M. Tusi, M. Brandalise, O.V. Correa, A.O. Neto, M. Linardi, E.V. Spinacé, Preparação de eletrocatalisadores PtRu/C pelo método de carbonização hidrotérmica para aplicação na eletro-oxidação de metanol, 17ํ Congresso Brasileiro de Engenharia e Ciências dos Materiais, Foz do Iguaçu - Brasil, 2006.

[3] M.M. Tusi, M. Brandalise, O.V. Correa, A.O. Neto, M. Linardi, E.V. Spinacé, Preparação de eletrocatalisadores PtRu/C pelo método de carbonização hidrotérmica para aplicação na eletro-oxidação de metanol, XVIII Congreso de la Sociedad Iberoamericana de Electroquímica, Medellín - Colômbia, 2008.

[4] M.M. Tusi, M. Brandalise, O.V. Correa, A.O. Neto, M. Linardi, E.V. Spinacé, Ni/Carbon nanocomposite prepared by hydrothermal carbonization as support for PtRu nanoparticles, $9^{\text {th }}$ International Conference on Nanostructured Materials, Rio de Janeiro - Brasil, 2008.

[5] M.M. Tusi, G.G. Magalhães, M. Brandalise, O.V. Correa, R. Crisafulli, A.O. Neto, M. Linardi, E.V. Spinacé, Estudo da razão atômica Pt:Ru na preparação de eletrocatalisadores $\mathrm{PtRu} / \mathrm{C}$ pelo processo de carbonização hidrotérmica, XVII Simpósio Brasileiro de Eletroquímica e Eletroanalítica, Fortaleza - Brasil, 2009.

[6] M.M. Tusi, G.G. Magalhães, M. Brandalise, O.V. Correa, R.M. Piasentin, A.O. Neto, M. Linardi, E.V. Spinacé, The influence of carbon source on the activity of PtRu/C electrocatalysts prepared by hydrothermal carbonization process, $4^{\text {th }}$ International Symposium on Advanced Materials and Nanostructures, Santo André - Brasil, 2009.

[7] M.M. Tusi, G.G. Magalhães, M. Brandalise, O.V. Correa, R. Crisafulli, A.O. Neto, M. Linardi, E.V. Spinacé, Efecto de la fuente de carbono en la preparación de electrocatalizadores $\mathrm{PtRu} / \mathrm{C}$ por el método de la carbonización hidrotérmica, XVI Congreso Argentino de Catálisis, Buenos Aires - Argentina, 2009.

[8] M.M. Tusi, G.G. Magalhães, M. Brandalise, O.V. Correa, R. Crisafulli, A.O. Neto, M. Linardi, E.V. Spinacé, Efeito da adição de CTAB na preparação de eletrocatalisadores $\mathrm{PtRu} / \mathrm{C}$ por carbonização hidrotérmica, 15을 Congresso Brasileiro de Catálise e 5 Congresso de Catálise do Mercosul, Armação de Búzios - Brasil, 2009. 
[9] M.M. Tusi, M. Brandalise, J.C. Villalba, O.V. Correa, A.O. Neto, M. Linardi, E.V. Spinacé, Preparation of PtRu/carbon hybrid materials by hydrothermal carbonization: A study of the Pt:Ru atomic ratio, Seventh International Latin American Conference on Powder Technology, Atibaia - Brasil, 2009.

[10] M.M. Tusi, M. Brandalise, R.W.R. Verjulio-Silva, O.V. Correa, J.C. Villalba, F.J. Anaissi, A.O. Neto, M. Linardi, E.V. Spinacé, Preparation of PtRu/C electrocatalysts by hydrothermal carbonization using different carbon sources, $10^{\text {th }}$ International Symposium "Scientific Bases for the Preparation of Heterogeneous Catalysts, Louvain-laNeuve - Bélgica, 2010.

[11] M.M. Tusi, N.S.O. Polanco, M. Brandalise, O.V. Correa, A.O. Neto, M. Linardi, E.V. Spinacé, Influência do íon tetrapropilamônio na síntese de híbridos PtRu/Carbono por carbonização hidrotérmica, $19^{\circ}$ Congresso Brasileiro de Engenharia e Ciências dos Materiais, Campos do Jordão - Brasil, 2010.

\subsection{TRABALHOS PUBLICADOS EM PERIÓDICOS}

[1] M.M. Tusi, M. Brandalise, O.V. Correa, A.O. Neto, M. Linardi, E.V. Spinacé, Preparation of PtRu/Carbon Hybrids by Hydrothermal Carbonization Process, Materials Research, 10, 2007, 171.

[2] M.M. Tusi, M. Brandalise, O.V. Correa, A.O. Neto, M. Linardi, E.V. Spinacé, Preparation of PtRu/C Electrocatalysts by Hydrothermal Carbonization Process for Methanol Electro-oxidation, Portugaliae Electrochimica Acta, 27, 2009, 345.

[3] M.M. Tusi, M. Brandalise, R.W.R. Verjulio-Silva, O.V. Correa, J.C. Villalba, F.J. Anaissi, A.O. Neto, M. Linardi, E.V. Spinacé, Preparation of PtRu/C electrocatalysts by hydrothermal carbonization using different carbon sources, Studies in Surface Science and Catalysis, $175,2010,581$.

\subsection{PATENTES DE PROCESSOS}

[1] E.V. Spinacé, M. Linardi, M.M. Tusi, A.O. Neto, M. Brandalise, Processo de preparação de materiais híbridos metal/carbono nanoestruturados via carbonização hidrotérmica para aplicação como eletrocatalisadores em células a combustível de baixa temperatura de operação, pedido de patente PI0703887-9. 


\section{REFERÊNCIAS BIBLIOGRÁFICAS}

[1] MOON, Y.S.; SONN, Y.H. Productive energy consumption and economic growth: An endogenous growth model and its empirical application. Resource and Energy Economics, v. 18, n. 2, p. 189200, 1996.

[2] KARANFIL, F. Energy consumption and economic growth revisited: Does the size of unrecorded economy matter? Energy Policy, v. 36, n. 8, p. 3029-3035,2008.

[3] SADORSKY, P. Renewable energy consumption and income in emerging economies. Energy Policy, v. 37, n. 10, p. 4021-4028, 2009.

[4] SADORSKY, P. The impact of financial development on energy consumption in emerging economies. Energy Policy, v. 38, n. 5, p. 2528-2535, 2010.

[5] GOLDEMBERG, J.; COELHO, S.T.; REI, F. Brazilian energy matrix and sustainable development. Energy for Sustainable Development, v. 6, n. 4, p. 55-59, 2002.

[6] QIANG, L.; XING-KANG, Q. World energy structure and choices of Chinese energy strategy. Procedia Earth and Planetary Science, v. 1, n. 1, p. 1723-1729, 2009.

[7] WITHAGEN, C. Pollution and exhaustibility of fossil fuels. Resource and Energy Economics, v. 16, n. 3, p. 235-242, 1994.

[8] ASMUS, P. Power to the people: Local governments go green. The Electricity Journal, v. 10, n. 9, p. 78-82, 1997.

[9] SPINACÉ, E.V.; NETO, A.O.; LINARDI, M. Electro-oxidation of methanol and ethanol using $\mathrm{PtRu} / \mathrm{C}$ electrocatalysts prepared by spontaneous deposition of platinum on carbon-supported. Journal of Power Sources, v. 129, n. 2, p. 121-126, 2004.

[10] GONZALEZ, E.R. Eletrocatálise e poluição ambiental. Química Nova, v. 23, n. 2, p. 262-266, 2000.

[11] WENDT, H.; GÖTZ, M.; LINARDI, M. Tecnologia de células a combustível. Química Nova, v. 23, n. 4, p. 538-546, 2000.

[12] ANDÚJAR, J.M.; SEGURA, F. Fuel cells: History and updating. A walk along two centuries Renewable and Sustainable Energy Reviews, v. 13, n. 9, p. 2309-2322, 2009.

[13] WEE, J.H.; LEE, K.Y.; KIM, S.H. Fabrication methods for low-Pt-loading electrocatalysts in proton exchange membrane fuel cell systems. Journal of Power Sources, v. 165, n. 2, p. 667-677, 2007.

[14] WENDT, H.; LINARDI, M.; ARICÓ, E.M. Células a combustível de baixa potência para aplicações estacionárias. Química Nova, v. 25, n. 3, p. 470-476, 2002.

[15] ROTH, C.; BENKER, N.; THEISSMAN, R.; NICHOLS, R.J.; SCHIFFRIN, D.J. Bifunctional Electrocatalysis in Pt-Ru Nanoparticle 
Systems. Langmuir, v. 24, n. 5, p. 2191-2199, 2008.

[16] ARENZ, M.; STAMENKOVIC, V.; BLIZANAC, B.B.; MAYRHOFER, K.J.; MARKOVIC, N.M.; ROSS, P.N. Carbon-supported Pt-Sn electrocatalysts for the anodic oxidation of $\mathrm{H}_{2}, \mathrm{CO}$, and $\mathrm{H}_{2} / \mathrm{CO}$ mixtures.: Part II: The structure-activity relationship. Journal of Catalysis, v. 232, n.2, p. 402-410, 2005.

[17] URBAN, P.M.; FUNKE, A.; MÜLLER, J.T.; HIMMEN, M.; DOCTER, A. Catalytic processes in solid polymer electrolyte fuel cell systems. Applied Catalysis A: General, v. 221, n. 1-2, 459-470, 2001.

[18] GOETZ, M.; WENDT, H. Binary and ternary anode catalyst formulations including the elements $\mathrm{W}, \mathrm{Sn}$ and Mo for PEMFCs operated on methanol or reformate gás. Electrochimica Acta, n. 43, n. 24, p. 3637-3644, 1998.

[19] LAMY, C.; BELGSIR, E.M.; LÉGER, J.M. Electrocatalytic oxidation of aliphatic alcohols: Application to the direct alcohol fuel cell (DAFC). Journal of Applied Electrochemistry, v. 31, n. 7, p. 799-809, 2001.

[20] ZHOU, W.J.; ZHOU, B.; LI, W.Z.; ZHOU, Z.H.; SONG, S.Q.; SUN, G.Q.; XIN, Q.; DOUVARTZIDES, S.; GOULA, M.; TSIAKARAS, P. Performance comparison of low-temperature direct alcohol fuel cells with different anode catalysts. Journal of Power Sources, v. 126, n. 1-2, p.16-22, 2004.

[21] LÉGER, J.M.; ROUSSEAU, S.; COUTANCEAU, C.; HAHN, F.; LAMY, C. How bimetallic electrocatalysts does work for reactions involved in fuel cells? Example of ethanol oxidation and comparison to methanol. Electrochimica Acta, v. 50, n. 25-26, p. 5118-5125, 2005.

[22] SPINACÉ, E.V.; LINARDI, M.; NETO, A.O. Co-catalytic effect of nickel in the electro-oxidation of ethanol on binary Pt-Sn electrocatalysts. Electrochemistry Communications, v. 7, n. 4, p. 365-369, 2005.

[23] LIU, H.; SONG, C.; ZHANG, L.; ZHANG, J.; WANG, H.; WILKINSON, D.P. A review of anode catalysis in the direct methanol fuel cell. Journal of Power Sources, v. 155, n. 2, p. 95-110, 2006.

[24] SPINACÉ, E.V.; NETO, A.O.; VASCONCELOS, T.R.R.; LINARDI, M. Electro-oxidation of ethanol using PtRu/C electrocatalysts prepared by alcohol-reduction process. Journal of Power Sources, v. 137, n. 1, p. 17-23, 2004.

[25] LUHUA, J.; HAIXIA, Z.; GONGQUAN, S.; QIN, X. Influence of Preparation Method on the Performance of PtSn/C Anode Electrocatalyst for Direct Ethanol Fuel Cells. Chinese Journal of Catalysis, v. 27, n. 1, p. 15-19, 2006.

[26] SERP, P.; CORRIAS, M.; KALCK, P. Carbon nanotubes and nanofibers in catalysis. Applied Catalysis A: General, v. 253, n. 2, p. 337-358 2003.

[27] GUO, J.; SUN, G.; WANG, Q.; WANG, G.; ZHOU, Z.; TANG, S.; JIANG, L.; ZHOU, B.; XIN, Q. Carbon nanofibers supported Pt-Ru electrocatalysts for direct methanol fuel cells. Carbon, v. 44, n. 1, 
p. 152-157, 2006.

[28] PARK, K.W.; SUNG, Y.E.; HAN, S.; YUN, Y.; HYEON, T. Origin of the Enhanced Catalytic Activity of Carbon Nanocoil-Supported PtRu Alloy Electrocatalysts. Journal of Physical Chemistry B, v. 108, n. 3, p. 939-944, 2004.

[29] TITIRICI, M.M.; THOMAS, A.; YU, S.H.; MÜLLER, J.O.; ANTONIETTI, M. A Direct Synthesis of Mesoporous Carbons with Bicontinuous Pore Morphology from Crude Plant Material by Hydrothermal Carbonization. Chemistry of Materials, v. 18, n. 16, p. 3808-3812, 2006.

[30] TITIRICI, M.M.; ANTONIETTI, M.; THOMAS, A. A Generalized Synthesis of Metal Oxide Hollow Spheres Using a Hydrothermal Approach. Chemistry of Materials, v. 19, n. 17, p. 4205-4212, 2007.

[31] QIAN, H.S.; YU, S.H.; LUO, L.B.; GONG, J.Y.; FEI, L.F.; LIU, X.M. Synthesis of Uniform Te@Carbon-Rich Composite Nanocables with Photoluminescence Properties and Carbonaceous Nanofibers by the Hydrothermal Carbonization of Glucose. Chemistry of Materials, v. 18, n. 8, p. 2102-2108, 2006.

[32] YU, S.H.; CUI, X.; LI, L.; LI, K.; YU, B.; ANTONIETTI, M.; CÖLFEN, H. From Starch Metal/Carbon Nanostructure: Hydrothermal Metal-Catalized Carbonization. Advanced Materials, v. 16, n. 18, p. 1636-1640, 2004.

[33] KIM, P.; JOO, J.B.; KIM, W.; KIM, J.; SONG, I.K. YI, J. Graphitic spherical carbon as a support for a PtRu-alloy catalyst in the methanol electro-oxidation. Catalysis Letters, v. 112, n. 3-4, p. 213-218, 2006.

[34] PIERSON, H.O. Handbook of carbon, graphite, diamond and fullerenes: properties, processing and applications. Park Ridge, $\mathrm{NJ}$ : Noyes Publications, 1993.

[35] TICIANELLI, E.A.; GONZALEZ, E.R. Célula a combustível: uma alternativa promissora para a geração de eletricidade. Química Nova, v.12, n.3, p. 268-272, 1989.

[36] WEE, J.H. Applications of proton exchange membrane fuel cell systems. Renewable and Sustainable Energy Reviews, v. 11, n. 8, p. 1720-1738, 2007.

[37] KIRUBAKARAN, A.; JAIN, S.; NEMA, R.K. A review on fuel cell technologies and power electronic interface. Renewable and Sustainable Energy Reviews, v. 13, n. 9, p. 2430-2440, 2009.

[38] LINARDI, M. Introdução à ciência e tecnologia de células a combustível. São Paulo, SP: Artliber, 2010.

[39] BALAT, M. Potential importance of hydrogen as a future solution to environmental and transportation problems. International Journal of Hydrogen Energy, v. 33, n. 15, p. 4013-4029, 2008.

[40] VIGIER, F.; ROUSSEAU, S.; COUTANCEAU, C.; LÉGER, J.M.; LAMY, C. Electrocatalysis for the direct alcohol fuel cell. Topics in Catalysis, v. 40, n. 1-4, p. 111-121, 2006.

[41] ZEGERS, P. Fuel cell commercialization: The key to a hydrogen 
economy. Journal of Power Sources, v. 154, n. 2, p. 497-502, 2006.

[42] HOLLADAY, J.D.; HU, J.; KING, D.L.; WANG, Y. An overview of hydrogen production technologies. Catalysis Today, v. 139, n. 4, p. 244-260, 2009.

[43] ROSEN, M.A. Advances in hydrogen production by thermochemical water decomposition: A review. Energy, v. 35, n. 2, p. 1068-1076, 2010.

[44] ABBAS, H.F.; DAUD, W.M.A.W. Hydrogen production by methane decomposition: A review. International Journal of Hydrogen Energy, v. 35, n. 3, p. 1160-1190, 2010.

[45] ROSS, D.K. Hydrogen storage: The major technological barrier to the development of hydrogen fuel cell cars. Vacuum, v. 80, n. 10, p. 10841089, 2006.

[46] PRINCIPI, G.; AGRESTI, F.; MADDALENA, A.; RUSSO, S.L. The problem of solid state hydrogen storage. Energy, v. 34, n. 12, p. 20872091, 2009.

[47] ZHOU, L. Progress and problems in hydrogen storage methods. Renewable and Sustainable Energy Reviews, v. 9, n. 4, p. 395-408, 2005.

[48] NETO, A.O.; DIAS, R.R.; TUSI, M.M.; LINARDI, M.; SPINACÉ, E.V. Electro-oxidation of methanol and ethanol using PtRu/C, PtSn/C and $\mathrm{PtSnRu} / \mathrm{C}$ electrocatalysts prepared by an alcohol-reduction process. Journal of Power Sources, v. 166, n. 1, p. 87-91, 2007.

[49] LAMY, C.; ROUSSEAU, S.; BELGSIR, E.M.; COUTANCEAU, C.; LÉGER, J.M. Recent progress in the direct ethanol fuel cell: development of new platinum-tin electrocatalysts. Electrochimica Acta, v. 49, n. 22-23, p. 3901-3908, 2004.

[50] PAPOUTSIS, A.; LÉGER, J.M.; LAMY, C. Study of the kinetics of adsorption and electro-oxidation of $\mathrm{MeOH}$ on $\mathrm{Pt}(100)$ in an acid medium by programmed potential voltammetry. Journal of Electroanalytical Chemistry, v. 359, n. 1-2, p. 141-160, 1993.

[51] COUTANCEAU, C.; BRIMAUD, S.; LAMY, C.; LÉGER, J.M.; DUBAU, L.; ROUSSEAU, S.; VIGIER, F. Review of different methods for developing nanoelectrocatalysts for the oxidation of organic compounds. Electrochimica Acta, v. 53, n. 23, p. 6865-6880, 2008.

[52] KAMARUDIN, S.K.; ACHMAD, F.; DAUD, W.R.W. Overview on the application of direct methanol fuel cell (DMFC) for portable electronic devices. International Journal of Hydrogen Energy, v. 34, n. 16, p. 6902-6916, 2009.

[53] LEE, C.H.; LEE, C.W.; KIN, D.I.; BAE, S.E. Characteristics of methanol oxidation on Pt-Ru catalysts supported by HOPG in sulfuric acid. International Journal of Hydrogen Energy, v. 27, n. 4, p. 445-450, 2002.

[54] LAMY, C.; LIMA, A.; LERHUN, V.; DELIME, F.; COUTANCEAU, C.; LÉGER, J.M. Recent advances in the development of direct alcohol fuel 
cells (DAFC). Journal of Power Sources, v. 105, n. 2, p. 283-296, 2002.

[55] XU, C.; FAGHRI, A.; LI, X.; WARD, T. Methanol and water crossover in a passive liquid-feed direct methanol fuel cell. International Journal of Hydrogen Energy, v. 35, n. 4, p. 1769-1777, 2010.

[56] HEINZEL, A.; BARRAGÁN, V.M. A review of the state-of-the-art of the methanol crossover in direct methanol fuel cells. Journal of Power Sources, v. 84, n. 1, p. 70-74, 1999.

[57] GOJKOVIĆ, S.L.; VIDAKOVIĆ, T.R.; DUROVIĆ, D.R. Kinetic study of methanol oxidation on carbon-supported PtRu electrocatalyst. Electrochimica Acta, v. 48, n. 24, p. 3607-3614, 2003.

[58] VIDAKOVIĆ, T.; CHRISTOV, M.; SUNDMACHER, K.; NAGABHUSHANA, K.S.; FEI, W.; KINGE, S.; BÖNNEMANN, H. PtRu colloidal catalysts: Characterisation and determination of kinetics for methanol oxidation. Electrochimica Acta, v. 52, n. 6, p. 2277-2284, 2007.

[59] SUN, Y.P.; XING, L.; SCOTT, K. Analysis of the kinetics of methanol oxidation in a porous Pt-Ru anode. Journal of Power Sources, v. 195, n. 1, p. 1-10, 2010.

[60] IWASITA, T. Electrocatalysis of methanol oxidation. Electrochimica Acta, v. 47, n. 22-23, p. 3663-3674, 2002

[61] BATISTA, E.A.; MALPASS, G.R.P.; MOTHEO, A.J.; IWASITA, T. New insight into the pathways of methanol oxidation. Electrochemistry Communications, v. 5, n. 10, p. 843-846, 2003.

[62] BATISTA, E.A.; MALPASS, G.R.P.; MOTHEO, A.J.; IWASITA, T. New mechanistic aspects of methanol oxidation. Journal of Electroanalytical Chemistry, v. 571, n. 2, p. 273-282, 2004.

[63] FERRIN, P.; NILEKAR, A.U.; GREELEY, J.; MAVRIKAKIS, M.; ROSSMEISL, J. Reactivity descriptors for direct methanol fuel cell anode catalysts. Surface Science, v. 602, n. 21, p. 3424-3431, 2008.

[64] SRIRAMULU, S.; JARVI, T.D.; STUVE, E.M. Reaction mechanism and dynamics of methanol electrooxidation on platinum (111). Journal of Electroanalytical Chemistry, v. 467, n. 1-2, p. 132-142, 1999.

[65] NETO, A.O.; LINARDI, M.; GONZALEZ, E.R. Oxidação eletroquímica do metanol sobre partículas de PtRu e PtMo suportadas em carbono de alta área superficial. Eclética Química, v. 28, n. 2, p. 55-62, 2003.

[66] WENDT, H.; SPINACÉ, E.V.; NETO, A.O.; LINARDI, M. Electrocatalysis and electrocatalysts for low temperature fuel cells: Fundamentals, state of the art, research and development. Química Nova, v. 28, n. 6, p. 1066-1075, 2005.

[67] NETO, A.O.; WATANABE, A.Y.; BRANDALISE, M.; TUSI, M.M.; RODRIGUES, R.M.S.; LINARDI, M.; SPINACÉ, E.V.; FORBICINI, C.A.L.G.O. Preparation and characterization of Pt-Rare Earth/C electrocatalysts using an alcohol reduction process for methanol electro-oxidation. Journal of Alloys and Compounds, v. 476, n. 1-2, 
p. 288-291, 2009.

[68] LONG, J.W.; STROUD, R.M.; LYONS, K.E.S.; ROLISON, D.R. How To Make Electrocatalysts More Active for Direct Methanol OxidationsAvoid PtRu Bimetallic Alloys! Journal of Physical Chemistry B, v. 104, n. 42, p. 9772-9776, 2000.

[69] ROTH, C.; PAPWORTH, A.J.; HUSSAIN, I.; NICHOLS, R.J.; SCHIFFRIN, D.J. A Pt/Ru nanoparticulate system to study the bifunctional mechanism of electrocatalysis. Journal of Electroanalytical Chemistry, v. 581, n. 1, p. 79-85, 2005.

[70] FRELINK, T.; VISSCHER, W.; VAN VEEN, J.A.R. On the role of $R u$ and $\mathrm{Sn}$ as promotors of methanol electro-oxidation over Pt. Surface Science, v. 335, p. 353-360, 1995.

[71] DEMIRCI, U.B. Theoretical means for searching bimetallic alloys as anode electrocatalysts for direct liquid-feed fuel cells. Journal of Power Sources, v. 173, n. 1, p. 11-18, 2007.

[72] LIMA, F.H.B.; GONZALEZ, E.R. Ethanol electro-oxidation on carbonsupported $\mathrm{Pt}-\mathrm{Ru}, \mathrm{Pt}-\mathrm{Rh}$ and $\mathrm{Pt}-\mathrm{Ru}-\mathrm{Rh}$ nanoparticles. Electrochimica Acta, v. 53, n. 6, p. 2963-2971, 2008.

[73] MIN, M.K.; CHO, J.; CHO, K.; KIM, H. Particle size and alloying effects of Pt-based alloy catalysts for fuel cell applications. Electrochimica Acta, v. 45, n. 25-26, p. 4211-4217, 2000.

[74] LIU, P.; LOGADOTTIR, A.; NØRSKOV, J.K. Modeling the electrooxidation of $\mathrm{CO}$ and $\mathrm{H} 2 / \mathrm{CO}$ on $\mathrm{Pt}, \mathrm{Ru}, \mathrm{PtRu}$ and Pt3Sn. Electrochimica Acta, v. 48, n. 25-26, p. 3731-3742, 2003.

[75] SANTOS, E.; SCHMICKLER, W. Fundamental aspects of electrocatalysis. Chemical Physics, v. 332, n. 1, p. 39-47, 2007.

[76] CAMPANATI, M.; FORNASARI, G.; VACCARI, A. Fundamentals in the preparation of heterogeneous catalysts. Catalysis Today, v. 77 , n. 4, p. 299-314, 2003.

[77] PEREGO, C.; VILLA, P. Catalyst preparation methods. Catalysis Today, v. 34, n. 3-4, p. 281-305, 1997.

[78] ANDREW, S.P.S. Theory and practice of the formulation of heterogeneous catalysts. Chemical Engineering Science, v. 36, n. 9, p. 1431-1445, 1981.

[79] GREENWOOD, N.N.; EARNSHAW, A. Chemistry of the elements. Burlington, MA: Butterworth-Heinemann, 1997.

[80] URRY, G. Elementary equilibrium chemistry of carbon. New York, N.Y.: John Wiley \& Sons, 1989.

[81] OLIVEIRA, I.R.; STUDART, A.R.; SILVA JÚNIOR, F.A.; PANDOLFELLI, V.C. Estabilização de suspensões aquosas contendo grafite. Cerâmica, v. 46, n. 300, p. 186-195, 2000.

[82] SOUZA FILHO, A.G.; FAGAN, S.B. Funcionalização de nanotubos de carbono. Química Nova, v. 30, n.7, p. 1695-1703, 2007. 
[83] ZHANG, M.; LI, J. Carbon nanotube in different shapes. Materials Today, v. 12, n. 6, p. 12-18, 2009.

[84] SEVILLA, M.; LOTA. G.; FUERTES, A.B. Saccharide-based graphitic carbon nanocoils as supports for $\mathrm{PtRu}$ nanoparticles for methanol electrooxidation. Journal of Power Sources, v. 171, n. 2, p. 546-551, 2007.

[85] PARK, I.S.; PARK, K.W.; CHOI, J.H.; PARK, C.R.; SUNG, Y.E. Electrocatalytic enhancement of methanol oxidation by graphite nanofibers with a high loading of $\mathrm{PtRu}$ alloy nanoparticles. Carbon, v. 45, n. 1, p. 28-33, 2007.

[86] PRABHURAM, J.; ZHAO, T.S.; LIANG, Z.X.; CHEN, R. A simple method for the synthesis of PtRu nanoparticles on the multi-walled carbon nanotube for the anode of a DMFC. Electrochimica Acta, v. 52, n. 7, p. 2649-2656, 2007.

[87] SHANOV, V.; YUN, Y.H.; SCHULZ, M.J. Synthesis and characterization of carbon nanotube materials. Journal of the University of Chemical Technology and Metallurgy, v. 41, n. 4, p. 377-390, 2006.

[88] HIRLEKAR, R.; YAMAGAR, M.; GARSE, H.; VIJ, M.; KADAM, V. Carbon nanotubes and its applications: A review. Asian Journal of Pharmaceutical and Clinical Research, v. 2, n. 4, p. 17-27, 2009.

[89] SZABÓ, A.; PERRI, C.; CSATÓ, A.; GIORDANO, G.; VUONO, D.; NAGY, J.B. Synthesis Methods of Carbon Nanotubes and Related Materials. Materials, v. 3, n. 5, p. 3092-3140, 2010.

[90] DENG, B.; XU, A.W.; CHEN, G.Y.; SONG, R.Q.; CHEN, L. Synthesis of Copper-Core/Carbon-Sheath Nanocables by a Surfactant-Assisted Hydrothermal Reduction/Carbonization Process. Journal of Physical Chemistry B, v. 110, n. 24, p. 11711-11716, 2006.

[91] FANG, Z.; TANG, K.; LEI, S.; LI, T. CTAB-assisted hydrothermal synthesis of $\mathrm{Ag} / \mathrm{C}$ nanostructures. Nanotechnology, v. 17, n. 12, p. 3008-3011, 2006.

[92] GONG, J.Y.; YU, S.H.; QIAN, H.S.; LUO, L.B.; LI, T.W. PVA-Assisted Hydrothermal Synthesis of Copper@Carbonaceous Submicrocables: Thermal Stability, and Their Conversion into Amorphous Carbonaceous Submicrotubes. Journal of Physical Chemistry B, v. 111, n. 10, p. 2490-2496, 2007.

[93] XUAN, S.; HAO, L.; JIANG, W.; GONG, X.; HU, Y.; CHEN, Z. A facile method to fabricate carbon-encapsulated $\mathrm{Fe}_{3} \mathrm{O}_{4}$ core/shell composites. Nanotechnology, v. 18, n. 3, p. 1-6, 2007.

[94] ZHANG, Z.; DUAN, H.; LI, S.; LIN, S. Assembly of Magnetic Nanospheres into One-Dimensional Nanostructured Carbon Hybrid Materials. Langmuir, v. 26, n. 9, p. 6676-6680, 2010.

[95] SEVILLA, M.; FUERTES, A.B. The production of carbon materials by hydrothermal carbonization of cellulose. Carbon, v. 47, n. 9, p. 2281-2289, 2009. 
[96] LIANG, X.; ZENG, M.; QI, C. One-step synthesis of carbon functionalized with sulfonic acid groups using hydrothermal carbonization. Carbon, v. 48, n. 6, p. 1844-1848, 2010.

[97] ZHENG, M.; LIU, Y.; JIANG, K.; XIAO, Y.; YUAN, D. Alcohol-assisted hydrothermal carbonization to fabricate spheroidal carbons with a tunable shape and aspect ratio. Carbon, v. 48, n. 4, p. 1224-1233, 2010.

[98] XIAO, H.; GUO, Y.; LIANG, X.; QI, C. One-step synthesis of novel biacidic carbon via hydrothermal carbonization. Journal of Solid State Chemistry, v. 183, n. 7, p. 1721-1725, 2010.

[99] LIANG, X.; XIAO, H.; SHEN, Y.; QI, C. One-step synthesis of novel sulfuric acid groups' functionalized carbon via hydrothermal carbonization. Materials Letters, v. 64, n. 8, p. 953-955, 2010.

[100] HEILMANN, S.M.; DAVIS, H.T.; JADER, L.R.; LEFEBVRE, P.A.; SADOWSKY, M.J.; SCHENDEL, F.J.; VON KEITZ, M.G.; VALENTAS, K.J. Hydrothermal carbonization of microalgae. Biomass and Bioenergy, v. 34, n. 6, p. 875-882, 2010.

[101] SEVILLA, M.; FUERTES, A.B. Catalytic graphitization of templated mesoporous carbons. Carbon, v. 44, n. 3, p. 468-474, 2006.

[102] RADMILOVIĆ, V.; GASTEIGER, H.A.; ROSS, P.N. Structure and Chemical Composition of a Supported Pt-Ru Electrocatalyst for Methanol Oxidation. Journal of Catalysis, v. 154, n. 1, p. 98-106, 1995.

[103] ANTOLINI, E.; CARDELLINI, F. Formation of carbon supported PtRu alloys: an XRD analysis. Journal of Alloys and Compounds, v. 315, n. 1-2, p. 118-122, 2001.

[104] ONODERA, T.; SUZUKI, S.; TAKAMORI, Y.; DAIMON, H. Improved methanol oxidation activity and stability of well-mixed PtRu catalysts synthesized by electroless plating method with addition of chelate ligands. Applied Catalysis A: General, v. 379, n. 1-2, p. 69-76, 2010.

[105] BATURINA, O.A.; AUBUCHON, S.R.; WYNNE, K.J. Thermal Stability in Air of Pt/C Catalysts and PEM Fuel Cell Catalyst Layers. Chemistry of Materials, v. 18, n. 6, p. 1498-1504, 2006.

[106] SELLIN, R.; CLACENS, J.M.; COUTANCEAU, C. A thermogravimetric analysis/mass spectroscopy study of the thermal and chemical stability of carbon in the Pt/C catalytic system. Carbon, v. 48, n. 8, p. 22442254, 2010.

[107] WU, J.; YUAN, X.Z.; WANG, H.; BLANCO, M.; MARTIN, J.J.; ZHANG, $\mathrm{J}$. Diagnostic tools in PEM fuel cell research: Part I Electrochemical techniques. International Journal of Hydrogen Energy, v. 33, n. 6, p. $1735-1746,2008$.

[108] SKOOG, D.A.; HOLLER, F.J.; NIEMAN, T.A. Princípios de Análise Instrumental. Porto Alegre, RS: Bookman, 2002.

[109] SPINACÉ, E.V.; VALE, L.A.I.; NETO, A.O.; LINARDI, M. Preparation of $\mathrm{PtRu} / \mathrm{C}$ anode electrocatalysts using $\mathrm{NaBH}_{4}$ as reducing agent and $\mathrm{OH}^{-}$ 
ions as stabilizing agent”. ECS Transactions, v. 5, n. 1, p. 89-94, 2006.

[110] REN, L.; XING, Y. Effect of pH on PtRu electrocatalysts prepared via a polyol process on carbon nanotubes. Electrochimica Acta, v. 53, n. 17, p. 5563-5568, 2008.

[111] TONANON, N.; TANTHAPANICHAKOON, W.; YAMAMOTO, T.; NISHIHARA, H.; MUKAI, S.R.; TAMON, H. Influence of surfactants on porous properties of carbon cryogels prepared by sol-gel polycondensation of resorcinol and formaldehyde. Carbon, v. 41, n. 15, p. 2981-2990, 2003.

[112] LIU, J.; RAVEENDRAN, P.; QIN, G.; IKUSHIMA, Y. Self-assembly of $\beta$ $D$ glucose-stabilized $\mathrm{Pt}$ nanocrystals into nanowire-like structures. Chemical Communications, n. 23, 2972-2974, 2005.

[113] SERRANO, V.G.; ALMEIDA, F.P.; VALLE, C.J.D.; VILLEGAS, J.P. Formation of oxygen structures by air activation. A study by FT-IR spectroscopy. Carbon, v. 37, n. 10, p.1517-1528, 1999.

[114] GUILMINOT, E.; FISCHER, F.; CHATENET, M.; RIGACCI, A.; FABRY, S.B.; ACHARD, P.; CHAINET, E. Use of cellulose-based carbon aerogels as catalyst support for PEM fuel cell electrodes: Electrochemical characterization. Journal of Power Sources, v. 166, n. 1, p. 104-111, 2007.

[115] LUA, A.C.; GUO, J. Activated carbon prepared from oil palm stone by one-step $\mathrm{CO}_{2}$ activation for gaseous pollutant removal. Carbon, v. 38, n. 7, p. 1089-1097, 2000.

[116] TUSI, M.M.; BRANDALISE, M.; CORREA, O.V.; NETO, A.O.; LINARDI, M.; SPINACÉ, E.V. Preparation of PtRu/Carbon Hybrids by Hydrothermal Carbonization Process. Materials Research, v. 10, n. 2, p. 171-175, 2007.

[117] SIERRA, M.C.S.; RUIZ, J.G.; PROIETTI, M.G.; BLASCO, J. Catalytic and structural properties of ruthenium monometallic and bimetallic catalysts: characterization by EXAFS and XRD. Journal of Molecular Catalysis A - Chemical, v. 96, n. 1, p. 65-75, 1995.

[118] GUO, J.W.; ZHAO, T.S.; PRABHURAM, J.; CHEN, R.; WONG, C.W. Preparation and characterization of a PtRu/C nanocatalyst for direct methanol fuel cells. Electrochimica Acta, v. 51, n. 4, p. 754-763, 2005.

[119] SHOJAI, F.; PETTERSSON, A.B.A.; MÄNTYLÄ, T.; ROSENHOLM, J.B. Electrostatic and electrosteric stabilization of aqueous slips of $3 \mathrm{Y}$ $\mathrm{ZrO}_{2}$ powder. Journal of the European Ceramic Society, v. 20, n. 3, p. 277-283, 2000.

[120] HANG, J.; SHI, L.; FENG, X.; XIAO, L. Electrostatic and electrosteric stabilization of aqueous suspensions of barite nanoparticles. Powder Technology, v. 192, n. 2, p. 166-170, 2009.

[121] BANDA, G.R.S.; SUFFREDINI, H.B.; CALEGARO, M.L.; TANIMOTO, S.T.; AVACA, L.A. Sol-gel-modified boron-doped diamond surfaces for methanol and ethanol electro-oxidation in acid medium. Journal of Power Sources, v. 162, n. 1, p. 9-20, 2006. 
[122] PROFETI, L.P.R.; SIMÕES, F.C.; OLIVI, P.; KOKOH, K.B.; CONTANCEAU, C.; LÉGER, J.M.; LAMY, C. Application of $\mathrm{Pt}+\mathrm{RuO}_{2}$ catalysts prepared by thermal decomposition of polymeric precursors to DMFC. Journal of Power Sources, v. 158, n. 2, p. 1195-1201, 2006.

[123] STARZ, K.A.; AUER, E.; LEHMANN, T.; ZUBER, R. Characteristics of platinum-based electrocatalysts for mobile PEMFC applications. Journal of Power Sources, v. 84, n. 2, p. 167-172, 1999.

[124] GAN, L.; DU, H.D.; LI, B.H.; KANG, F.Y. The effect of particle size on the interaction of Pt catalyst particles with a carbon black support. New Carbon Materials, v. 25, n. 1, p. 53-59, 2010.

[125] LIN, M.L.; HUANG, C.C.; LO, M.Y.; MOU, C.Y. Well-Ordered Mesoporous Carbon Thin Film with Perpendicular Channels: Application to Direct Methanol Fuel Cell. Journal of Physical Chemistry C, v. 112, n. 3, p. 867-873, 2008.

[126] SONG, S.; LIANG, Y.; LI, Z.; WANG, Y.; FU, R.; WU, D.; TSIAKARAS, $P$. Effect of pore morphology of mesoporous carbons on the electrocatalytic activity of $\mathrm{Pt}$ nanoparticles for fuel cell reactions. Applied Catalysis B: Environmental, v. 98, n. 3-4, p. 132-137, 2010.

[127] GASTEIGER, H.A.; MARKOVIĆ, N.; ROSS, P.N.; CAIRNS, E.J. Methanol electrooxidation on well-characterized Pt-Ru alloys. Journal of Physical Chemistry, v. 97, n. 46, p. 12020-12029, 1993.

[128] ROLISON, D.R.; HAGANS, P.L.; SWIDER, K.E.; LONG, J.W. Role of Hydrous Ruthenium Oxide in Pt-Ru Direct Methanol Fuel Cell Anode Electrocatalysts: The Importance of Mixed Electron/Proton Conductivity. Langmuir, v. 15, n. 3, p. 774-779, 1999.

[129] LU, Q.; YANG, B.; ZHUANG, L.; LU, J. Anodic Activation of PtRu/C Catalysts for Methanol Oxidation. Journal of Physical Chemistry B, v. 109, n. 5, p. 1715-1722, 2005.

[130] LU, Q.; YANG, B.; ZHUANG, L.; LU, J. Pattern Recognition on the Structure-Activity Relationship of Nano Pt-Ru Catalysts: Methodology and Preliminary Demonstration. Journal of Physical Chemistry B, v. 109, n. 18, p. 8873-8879, 2005.

[131] PROFETI, L.P.R.; PROFETI, D.; OLIVI, P. Pt-RuO 2 electrodes prepared by thermal decomposition of polymeric precursors as catalysts for direct methanol fuel cell applications. International Journal of Hydrogen Energy, v.34, n. 6, p. 2747-2757, 2009.

[132] ARICÒ, A.S.; BAGLIO, V.; BLASI, A.; MÓDICA, E.; ANTONUCCI, P.L.; ANTONUCCI, V. Analysis of the high-temperature methanol oxidation behaviour at carbon-supported Pt- Ru catalysts. Journal of Electroanalytical Chemistry, v. 557, n. 1, p.167-176, 2003.

[133] JIANG, L.; SUN, G.; ZHAO, X.; ZHOU, Z.; YAN, S.; TANG, S.; WANG, G.; ZHOU, B.; XIN, Q. Preparation of supported PtRu/C electrocatalyst for direct methanol fuel cells. Electrochimica Acta, v. 50, n. 12, p. 2371-2376, 2005

[134] YAN, S.; SUN, G.; TIAN, J.; JIANG, L.; QI, J.; XIN, Q. Polyol synthesis 
of highly active PtRu/C catalyst with high metal loading. Electrochimica Acta, v. 52, n. 4, p. 1692-1696, 2006.

[135] MA, L.; LIU, C.; LIAO, J.; LU, T.; XING, W.; ZHANG, J. High activity $\mathrm{PtRu} / \mathrm{C}$ catalysts synthesized by a modified impregnation method for methanol electro-oxidation. Electrochimica Acta, v. 54, n. 28, p. 72747279, 2009.

[136] WANG, X.; LIAO, J.; LIU, C.; XING, W.; LU, T. Facile synthesis of $\mathrm{PtRu} / \mathrm{C}$ electrocatalyst with high activity and high loading for passive direct methanol fuel cell by synergetic effect of ultrasonic radiation and mechanical stirring. Electrochemistry Communications, v. 11, n. 1, p. 198-201, 2009.

[137] LEE, K.S.; PARK, H.Y.; CHO, Y.H.; PARK, I.S.; YOO, S.J.; SUNG, Y.E. Modified polyol synthesis of PtRu/C for high metal loading and effect of post-treatment. Journal of Power Sources, v. 195, n. 4, p. 1031-1037, 2010.

[138] RALPH, T.R.; HOGARTH, M.P. Catalysis for low temperature fuel cells. Part I: The cathode challenges. Platinum Metals Review, v. 46, n. 1, p. 3-14, 2002.

[139] ZHOU, J.H.; HE, J.P.; JI, Y.J.; DANG, W.J.; LIU, X.L.; ZHAO, G.W.; ZHANG, C.X.; ZHAO, J.S.; FU, Q.B.; HU, H.P. CTAB assisted microwave synthesis of ordered mesoporous carbon supported $\mathrm{Pt}$ nanoparticles for hydrogen electro-oxidation. Electrochimica Acta, v. 52, n. 14, p. 4691-4695, 2007.

[140] SONG, Y.; GARCIA, R.M.; DORIN, R.M.; WANG, H.; QIU, Y.; COKER, E.N.; STEEN, W.A.; MILLER, J.E.; SHELNUTT, J.A. Synthesis of Platinum Nanowire Networks Using a Soft Template. Nano Letters, v. 7, n. 12, p. 3650-3655, 2007.

[141] SMITH, D.S.; KORGEL, B.A. The Importance of the CTAB Surfactant on the Colloidal Seed-Mediated Synthesis of Gold Nanorods. Langmuir, v. 24, n. 3, p. 644-649, 2008.

[142] TUSI, M.M.; MAGALHÃES, G.G.; BRANDALISE, M.; CORREA, O.V.; CRISAFULLI, R.; NETO, A.O.; LINARDI, M.; SPINACÉ, E.V. Efeito da adição de CTAB na preparação de eletrocatalisadores PtRu/C por carbonização hidrotérmica, In: CONGRESSO BRASILEIRO DE CATÁLISÉ, 15., 13-17 setembro, 2009, Armação de Búzios. Book of Abstracts of $15^{\text {th }}$ Brazilian Congress of Catalysis. Rio de Janeiro.

[143] JI, H.; WANG, T.; ZHANG, M.; SHE, Y.; WANG, L. Simple fabrication of nano-sized $\mathrm{NiO} 2$ powder and its application to oxidation reactions. Applied Catalysis A: General, v. 282, n. 1-2, p.25-30, 2005.

[144] FU, X.Z.; ZHU, Y.J.; XU, Q.C.; LI, J.; PAN, J.H.; XU, J.Q.; LIN, J.D.; LIAO, D.W. Nickel oxyhydroxides with various oxidation states prepared by chemical oxidation of spherical $\beta-\mathrm{Ni}(\mathrm{OH})_{2}$. Solid State lonics, v. 178, n. 13-14, p. 987-993, 2007.

[145] TUSI, M.M.; BRANDALISE, M.; CORREA, O.V.; NETO, A.O.; LINARDI, M.; SPINACÉ, E.V. Ni/Carbon nanocomposite prepared by 
hydrothermal carbonization as support for PtRu nanoparticles, In: INTERNATIONAL CONFERENCE ON NANOSTRUCTURED MATERIALS, 9., 1-6 junho, 2008, Rio de Janeiro. Abstracts of $9^{\text {th }}$ International Conference on Nanostructured Materials. Rio de Janeiro.

[146] VOGEL, A.I. Vogel's Textbook of macro and semimicro qualitative inorganic analysis, New York, NY: Longman, 1979.

[147] OH, H.S.; OH, J.G.; HONG, Y.G.; KIM, H. Investigation of carbonsupported Pt nanocatalyst preparation by the polyol process for fuel cell applications. Electrochimica Acta, v. 52, n. 25, p.7278-7285, 2007.

[148] RIBEIRO, V.A. Preparação de eletrocatalisadores PtRuNi/C pelo método da redução por álcool para aplicação como ânodo na oxidação direta de metanol em células a combustível de eletrólito polimérico sólido. 2008. Dissertação (Mestrado) - Instituto de Pesquisas Energéticas e Nucleares, São Paulo. 